Historic, Archive Document

Do not assume content reflects current scientific knowledge, policies, or practices. 



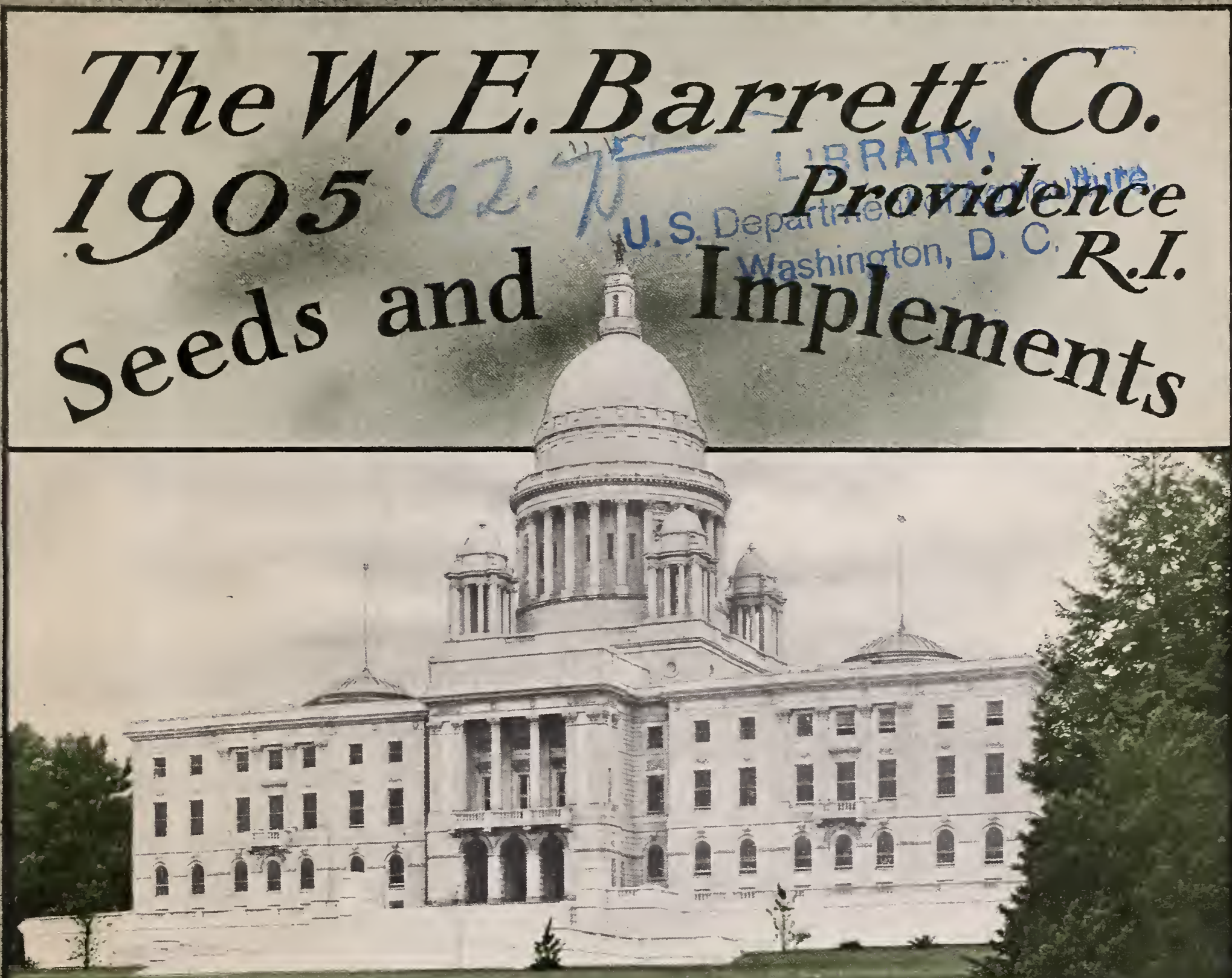

THE RHODE ISLAND STATE HOUSE GROUNDS, SHOWING THE BEAUTY OF OUR "CAPITOL" LAWN GRASS.

A RELIABLE AND UNEXCELLED MIXTURE FOR LAWNS, COMPOSED ENTIRELY OF CLEAN SEEDS. IT WILL PRODUCE BETTER RESULTS THAN ANY MIXTURE EVER BEFORE OFFERED. 
QUANTITY OF SEED USUALLY SOWN TO THE ACRE

Barley, broadcast

lic:an, Dwarf, in liills.

liean, Pole, in hills

leet, in drills.

Buckwheat, broisklcalst

Carrot, in drills

Corn, in liills

Com, for soiling

Clover, Alsilie

Clover, Red, alone.

Clover, White, alone

Clover, White, with ofher secels

("lover, Lucerne, alone.

(incumber, in hills

(imss, blue, alone

(irass, Hungarian

Grass, Lawn

Grass, Orchard

Grass, Red Top

(irass, R. I. Bent

(iriss, Timothy .

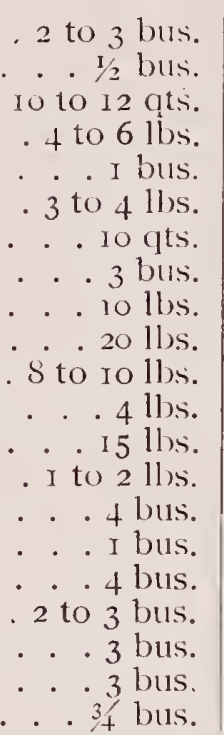

Millet .

Mustard

Oats, broadcast

Onion, in drills

Parsnip, in clrills

Pea, Early, in drills

Pea, Mlarrowfat, in drills

l'ea, broadcast

Radish, in drills

Radish, broadcast
Rye, broadcast .

Sillsify

Spinach, in drills

Turnip, in drills

Turnip, broadcast

Vetch, broadcast

W'heat, in drills

Wheat, broadcast

Timothy, Red Top together, for one acre: Io lbs.

Closer, r/2 bus. Timothy, I bus. Red Top (chafi), or 8 ltss. clean seed.

\section{BUG DEATH}

This insecticide and Plant-Food combined has been on the market for five years, and its sales have shown a large increase rach year. Ile can sa! to our customers that we give Bug Death our fullest endorsement. While the first cost to kill the bugs

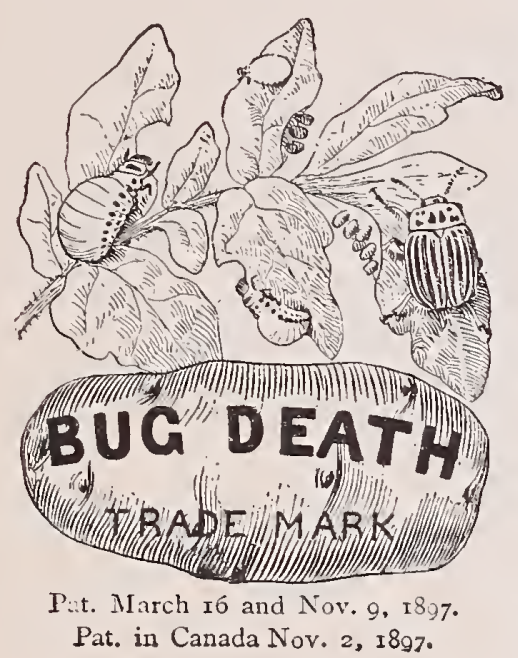

Pat. in Canada Nov. 2, 1897 . on an acre of potatoes is rather more than that of the arsenical insecticides, the results at harvesting time are entirely satisfactory, and where practical tests have been made the extra vielol of marketable potatoes has more than paid the entire expense. It is non-poisonous, which nialies it perfectly safe to use on all plants and vines.

Very beneficial results are obtained by using Bordeaux Mixture in connection with Bug Death, and they can be mixed and sprayed on the vines at the same time, with any of the spraying machines on the market for that purpose. Bug Death prevents blight.

\section{FOR SPRAYING FRUIT TREES}

Bug Death is perfectly harnless to use and apply, and Bug Death will protect your finit trees. It has been thoroughly tested by the large peach-and apple-growers of Maine, Nura Sicotia and Massachusetts.

Use Bug Death for your fruit trees. It kills the insect pests, protects the 1rees, promotes their vigorous gromth, gives freedom to the bees, and insures quality and quantity of fruit. No other agent can do this. Bug Death must be the reliance of the fruit-grower, who, by spraying. seeks after perfect iruit.

One-pound package

\section{PRICE-LIST}

Three-pound package

\$o I5 Twelve and one-lialf pound package... . \$ r oo

35 One hundred pound package .... 7 oo

50 Perfection Shaker, for applying dry

\section{TO DESTROY SAN JOSE SCALE, USE THE FOLLOWING}

Unslaked lime .

Take Io lbs. of the lime and 20 lbs. of the sulphur and boil thoroughly in 20 gallons of water for an hour and a half, or till the sulphur is thoroughly dissolved and the solution hecomes amber-colored, stirring frequently. Slake the rest of the lime by adding water, and while it is boiling add the salt and stir till this is all dissolved. Add this lime and salt mixture to the lime and sulphur nixture, and stir and cook thoroughly for half an hour longer. Then strain it through burlap into the spraying tank and add enough water to make the sixty gallons.

CAUSTIC POTASH WHALE-OIL SOAP is also recommended for the destruction of San José scale.

\section{VEGETABLE PLANTS AND ROOTS}

\section{CABBAGE PLANTS} Henderson's Summer... Io Drumhead Saroy .... I Stone-Mason
Early Jersey Wakefield . \$o IO \$0 60

\section{CELERY PLANTS}

Paris Golden

IV'hite Plume

60 Giant Pascal

60 Boston Market

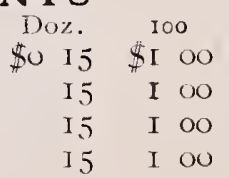

CAULIFLOWER PLANTS

Henderson's Snowball . . \$o 20 \$I 25

STRAWBERRY PLANTS

All Standard Varieties . . \$I $\$ 100 \quad \$ 500$

\section{CHIVES}

I 5 cts. per bunch, \$I.5o per doz.

EGGPLANT New York Improved $\ldots \ldots$ Doz.
LETTUCE PLANTS

All varieties ...... \$ \$0 15 $\$ 075$

PEPPER PLANTS

Bullnose . . . . . . . \$0 20 \$I 25 Ruby King . . . . . . .

Squash ........ 20 I 25

TOMATO PLANTS Acme Doz. 100 Dwarf Champion ..... . . 20 I 20 I 25 Stone ....... 20 I 25 


\section{THE W. E. BARRETT COMPANY'S}

\section{Fifty-Seventh Annual Catalogue SEEDS AND IMPLEMENTS}

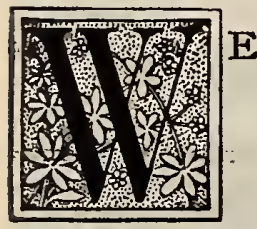

E are pleased to be able to report a decided improvement in seed crops this season, both for quantity and quality, as over the past two seasons, which were very discouraging to all parties. This improvement applies to the general list with the exception of Beans, which suffered badly the last part of the season, returns showing only from 30 to 50 per cent of a crop.

As to Prices, you will find quite a reduction from last year. We shall make no advance over these prices as long as our present stock lasts, but if we have to replenish at higher rates we claim the right to advance without notice.

Important.-Order early; in so doing you will avoid the delay which is liable to occur in the spring rush.

For Testing.-To those desiring for their own satisfaction to test any of our stock as to germination, we shall be pleased to furnish samples free.

Special Market-Gardeners' List.-For Market-Gardeners and others using a large quantity of seedfree upon application.

Seeds by Mail. - We send all seeds ordered at packet, ounce and quarter-pound rates free by mail, postage paid. To the prices of seeds quoted by the pound, and to those of Beans, Peas, Corn, etc., add for postage at the rate of 8 cents per pound, or 15 cents per quart.

Remittances may be made at our risk by Draft, P. O. Money Order, Express Company's Money Order, or Registered Letter.

All Vegetable Seeds sold at the uniform price of 5 cents per packet.

Remember, we make no charge for cartage.-Cloth bags for packing are charged only at cost, and are returnable at same rates if sound and in good condition.

WARRANTIES.-While we exercise great care to have all seeds pure, reliable and true to name, our seeds are sold without any warranty, expressed or implied, and without any responsibility in respect to crop. If our seeds are not accepted on these terms, they must be returned at once.

Seeds of the best quality will often fail through improper treatment. More failures result from disregard of the conditions necessary to germination than from the quality of the seeds used.

A proper temperature, sufficient moisture, and the soil in good condition are all of great importance. Seeds also differ as to temperature required for germination. Peas, Beets and Radishes start rapidly at a temperature of $45^{\circ}$, Vine seeds, Beans and other seeds of the same class require at least $60^{\circ}$; for this reason many seeds fail by too early planting. Besides, even after germination the young plants are liable to accidents; a sudden drop in the temperature or a strong, drying wind may destroy them altogether. Thus the conditions are as important as the vitality of the seed.

\section{The W. E. Barrett Co.}




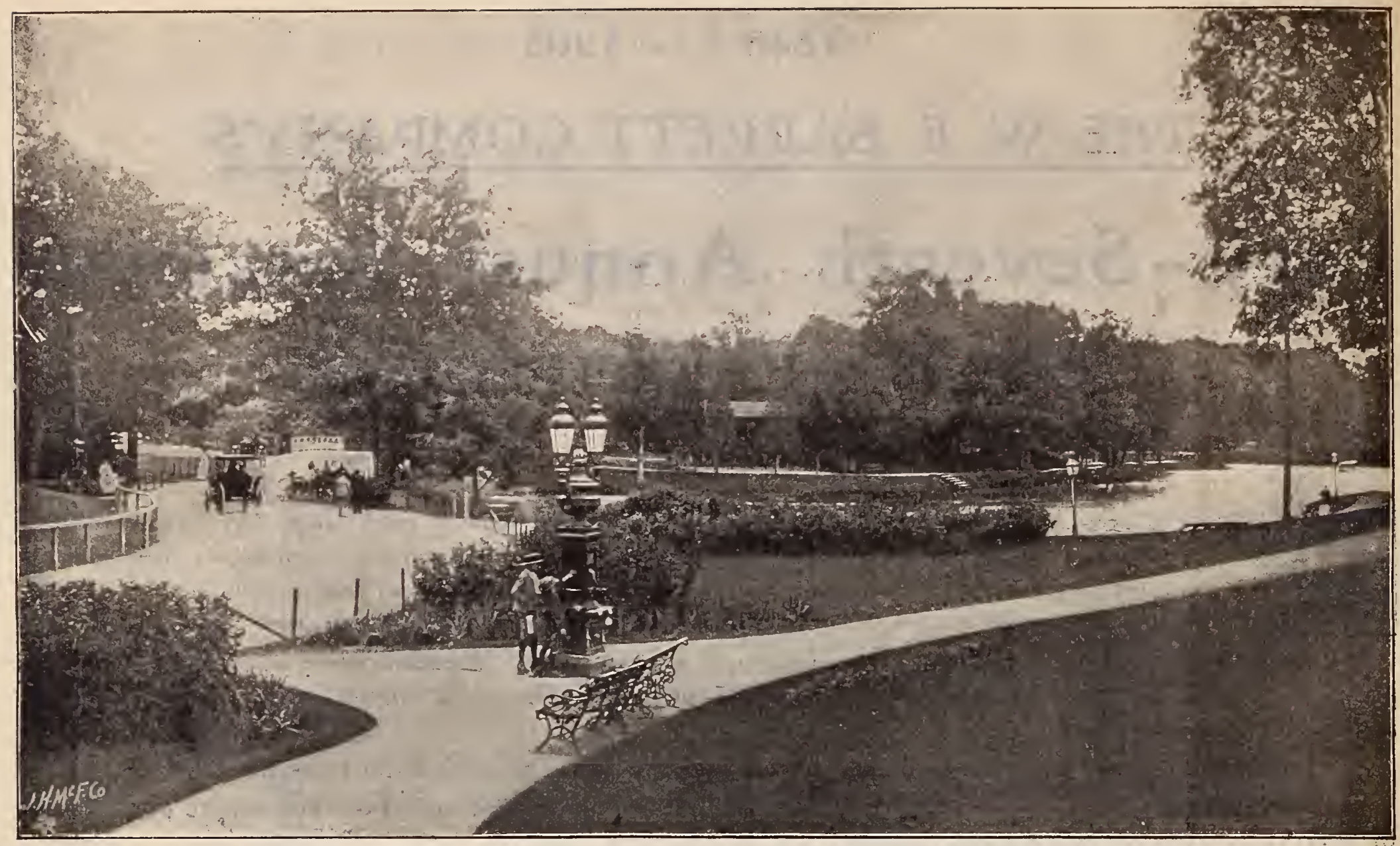

Scene at Roger Williams Park, Providence, Rhode Island

\section{Lawns and Their Management}

To insure a really fine lawn, there are several requisities : a good depth of rich soil, properly drained, and free from bould; ers immediately below the surface; a liberal dressing of thoroughly decayed manure (ten or twelve cords per acre); nicety of grading in the levels and slopes; a firm, smooth surface upon which to sow the seed; and a sufficient quantity of the very best lawn grass seed, suited to the situation. The latter item is of prime importance. Boulders below the :surface will, during the heat of summer, cause unsightly dry spots in an otherwise beautiful lawn; all such should be removed. A rich-soil, of good depth, and liberally fertilized, will maintain a fine greensward permanently, needing only an occasional top-dressing. Fresh strawy manure should never be used in making a lawn; when decaying it is liable to allow uneven settling of the soil.. Make a smooth surface with harrow and rake, and use a roller to make it firm and even, before sowing the seed. After sowing, cover the seed well by raking it in, and again use the roller to finish the work.

\section{The "Capitol" Lawn Seed}

IVe cannot say too much in regard to this mixture. The grounds around the "State. House" are a forcible recommendation to its quality and reliability. Sown down late in the spring, in two months' time it showed a sward equal to the best year-old lawn in the city. This mixture contains only clean seeds of the very best quality, entirely free from weeds or any foreign matter.

For lawns, tennis courts, croquet grounds, etc., the "Capitol" mixture gives a fine, smooth, velvety sward a few weeks after sowing Weight, $2 \$$ pounds to the bushel. Sow three bushels to the acre. Qt. $25 \mathrm{cts}$., pk. \$1.50, bus. \$5. (See front corer.)

\section{Park Lawn Seed}

This mixture we thave sold for many years,.. and it has "given general satisfaction. IVeight, 'T6 pounds to the bustrel. Sow foút bushels to the acre., Qt. is cts., pk. \$1, bus. $\$ 3.50$.

FOR SHADY PLACES in the lawn we have a special mixture, composed of grasses of habit and growth adapted for suclh situa tions. Qt. 25 cts., pk. $\$ 1.50$, bus. $\$ 5$.

\section{Seeds for Golf Links and Putting=Greens}

A specially preparé mixture for golf Tinks. Bus. \$2.50. I.

A combination, of grasses for \$pwing on putting greens, to produce a dense, close sward. Qt. $25 \mathrm{cts}$, pk. $5 \mathrm{r} .50$, bus. $\$ 5$ 


\section{A Feש Norelties and Specialties}

\section{GOLDEN CARMINE=PODDED HORTICULTURAL POLE BEAN}

A new strain of Horticultural Pole of sterling merit. Excts in earliness, quality, handsome appearance and productiveness. Rogers Bros., the introducers of this new variety, say" "In this variety we have a wonderfully robust grower, a week to ten dars earlier than Worcester Horticultural Pole. In comparison, the pods are equally large, stringless, bright golden color when very young; as the pods approach full size they are mottled and streaked with an unusually bright carmine color on the bright golden, which gives the pods (when ready for market) a strikingly beautiful and attractive appearance. This, together with its productiveness, will make it the most desirable strain of this popular Bean. Qt. $40 \mathrm{cts}, 1 / 2 \mathrm{pk}$. $\$ 1.25$.

\section{NEW DWARF STONE TOMATO}

A nother splendid new variety from Livingston. This is what he says of $1 \mathrm{t}$ : "The same sort of Tomato as Dwarf Champion, but the vine is of stronger growth, and the fruit is double the size. It is equally early, is equally prolific, and averaging double the size will bear double the crop. The shape of the fruit is perfect; it is very solid, ripens very evenly and is of excellent quality. The vines admit of planting half as near again as the common sorts." Oz. 40 cts., $1 / 41 \mathrm{~b}$. \$I.25, lb. \$4.

\section{CHINESE GIANT PEPPER}

Double the size of Ruby King. This is the largest and finest mild red Pepper. Truckers planting for mar ket will find Chinese Giant the most profitable variety they ever handled. Not only is it early in ripening and immensely productive for so large a Pepper, but its enormous size will cause it to sell most readily. The plants are vigorous in growth, but of stocky habit, seldom more than 2 feet in height. They are well branched and thickly set with enormous fruits, which appear to hang in clusters, so many being set on the comparatively small plants. Frequently half a dozen fruits will touch each other, as if in a single bunch; the strong growth of the plants and abundant foliage enable them to mature the large number of fruits nearly as early as the popular Ruby King. The flesh is thick, sweet and extremely mild. Oz. 50 cts., I/4 lb. \$I 5o, 1b. \$5. (See back cover.)

\section{THE DELICIOUS SQUASH}

Mr. Gregory, of Marblehead, Mass., who introduces this new variety, says of it: "The product of the work of years in careful selection, crossing and isolation. Its color is almost uniformly of a green shade. In size it closely follows the original Hubbard, between five and ten pounds. In thickness of flesh it surpasses nearly every other variety, the color being a dark orange, and for table use no other variety compares with it, not even the Hubbard itself when it was at its best, and like the old Hubbard, though at all times good, does not acquire its best qualities until winter." Oz. 20 cts., $1 / 4$ lb. $75 \mathrm{cts}$., 1b. $\$ 2.50$.

\section{METROPOLITAN SWEET CORN}

A new early sort, only a few days later than Cory. The ears are about 9 inches in length, io- to I2-rowed, well filled to the tip with large, deep kernels, which are very sweet and tender; in fact, possess that richness found in the later and larger kinds. It is an excellent variety for market-gardeners as well, on account of its size, earliness, productiveness and quality. Qt. 25 cts., 1/2pk. 65 cts., bus. $\$ 4$.

\section{NEW TOMATO, CHALK'S EARLY JEWEL}

The largest, smoothest, and finest flavored extra-early Tomato in cultivation.

The large, handsome fruits are very solid and deep through, being almost round or ball-shaped. An average specimen, will measure three and a half inches across by nearly three inches in depth from stem to blossom end. Color brightest scarlet, ripening right up to the stem without any cracks or green core. The foliage is rather open, admitting the sunlight to the center of each plant, so that all the fruits are thoroughly ripened; but the leaves are dark green and not inclined to curl as in most other extreme-early varieties. The thick flesh is bright scarlet, very solid, with comparatively few seeds, and of fine sweet flavor; skin thin, but sufficiently strong to make it a good shipper. Oz. 50 cts.

\section{TH CENTURY WHITE ROCK TURNIP}

Now firmly established as the finest strain of the White French Turnip on the market. Growing very smooth, free from straggling roots. Shape is perfect, while for quality it has no superior, and being fully three weeks earlier than the ordinary strain, can be planted later with the assurance of a crop. Oz. Io cts. I/lb. 30 cts., 1 b. 75 cts.

\section{PARIS GOLDEN SELF=BLANCHING CELERY}

Market-Gardeners' Stock.

This is the main-crop Celery in this vicinity, and, recognizing the fact of so much depending upon the quality of the seed, we use the utmost care in procuring our stock, which is grown for us by the most reliable grower in Europe, and thoroughly tested, before sent out, as to purity and germination, and we recommend it with every confidence. Oz. 5o cts., I/4lb. \$I.50, 1b. \$6.

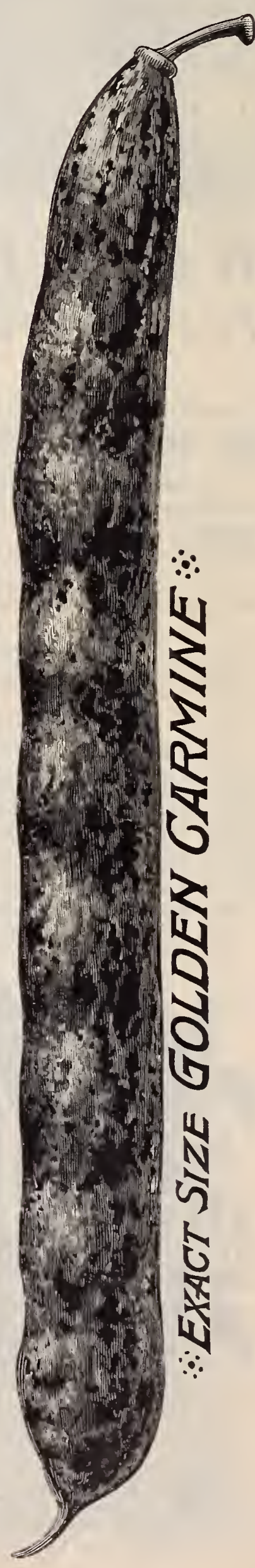




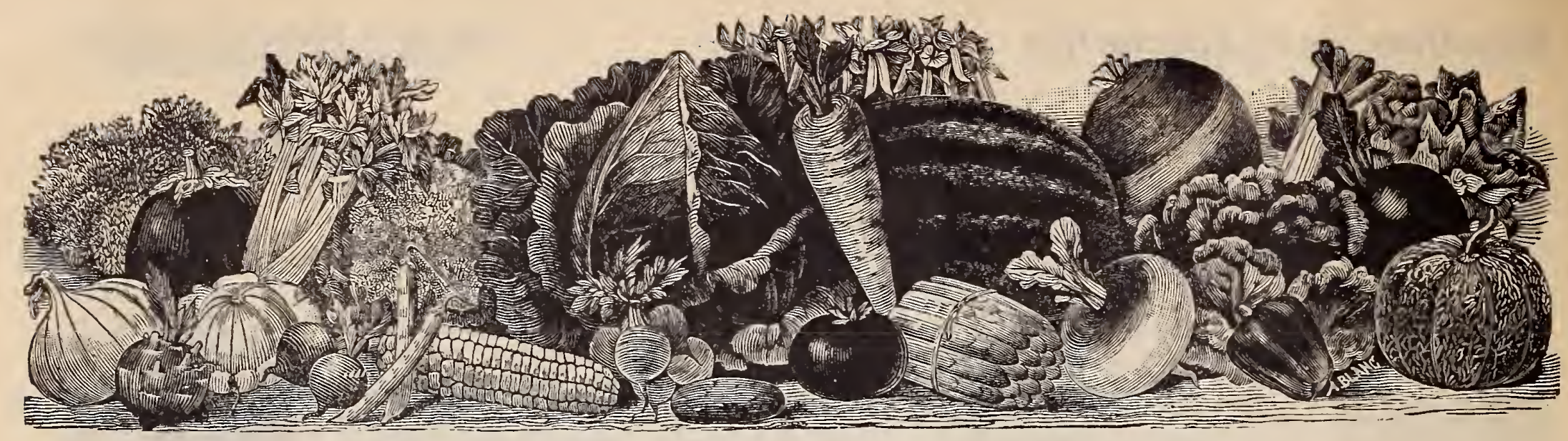

Best Grade Vegetable Seeds for Farm, Market and Kitchen=Gardens

\section{BEST ADAPTED TO THIS CLIMATE}

HOW SEEDS ARE SENT. POSTAGE PREPAID. IVe deliver free, at Catalogue prices, to any post office in the United States, all seeds

SEEDS SOLD BY MEASURE, when to be sent by mail, require, in addition to Catalogue prices, $8 \mathrm{cts}$. per pint and $15 \mathrm{cts}$. per quart for Peas and Beans, and $5 \mathrm{cts}$. per pint and $8 \mathrm{cts}$. per quart for Corn. To prices of seeds sold by the pound, add postage at the rate of $8 \mathrm{cts}$. per pound.

LIBERAL PREMIUMS. Remember that these cash discounts refer only to prices of seeds sold in packets, and not to prices of seeds sold by weight and measure. Cash must accompany the order in all cases.

On $\$ 1$ orders, select Seeds amounting to $\$ 1.25$. On $\$ 2$ orders, select Seeds amounting to $\$ 2.50$. On \$3 orders, select Seeds amounting to $\$ 3.75$

All Vegetable Seeds sold at the uniform price of $5 \mathrm{cts}$. per packet

FOR PREMIUMS ON FLOWER SEEDS, SEE FIRST PAGE F LOWER SEEDS.

\section{ASPARAGUS (sparger)}

This is one of the first and finest spring relishes which come to the table from the garden, and it really requires very little trouble in cultivation, since a bed once properly made and planted will last for years. The soil for the bed can hardly be made too rich, and the fertilizer should be well trenched-in to the depth of 2 feet or more. The roots should be planted as early in spring as the ground can be prepared, setting them a foot apart in rows 3 or 4 feet apart, with the crowns from 4 to 6 inches below the surface of the bed. Asparagus seed may be sown directly in the permanent bed and the plants thinned as they grow; or it may be sown elsewhere, and the seedlings transplanted the second year. An ounce of seed will sow 50 feet of drill, and produce' about 300 plants. Fair crops may be expected the third year.

Palmetto. Earlier than Colossal, with stalks as fine in size and quality, and more even and regular in growth. Oz. Io cts., $1 / 4 \mathrm{lb} .25$ cts., 1b. 75 cts.

colossal. Widely cultivated; very large, deep green, tender stalks of good flavor. The roots are

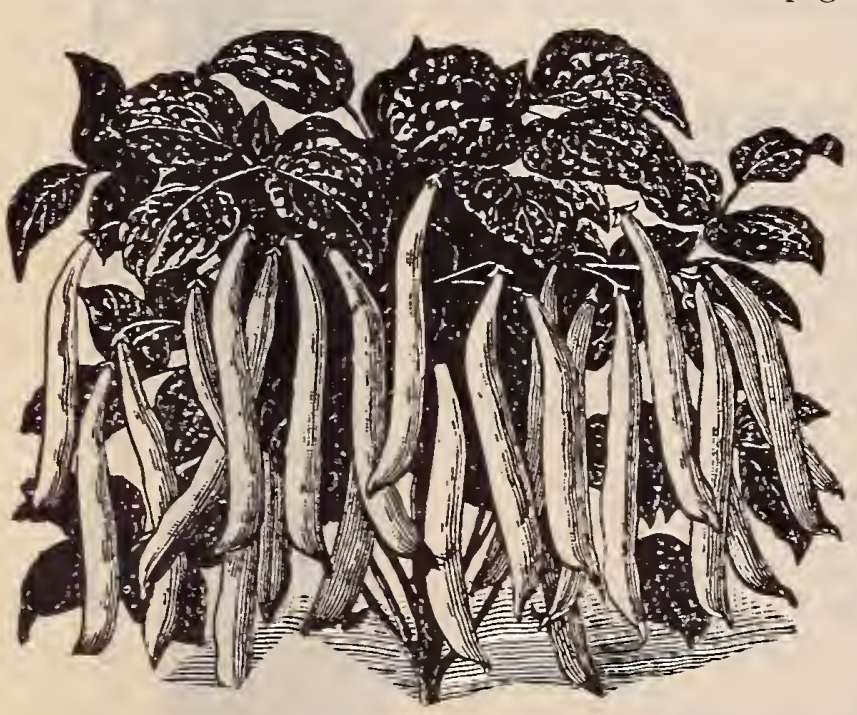
vigorous and productive. Oz. 10 cts., $1 / 4 \mathrm{lb} .20 \mathrm{cts}$,

ASPARAGUS ROOTS-

Palmetto: 2 years old..... \$I $00 \quad \$ 700$

Colossal. 2 years old..... 75600

Barr's Mammoth. 2 years old. . . I $\infty 00$

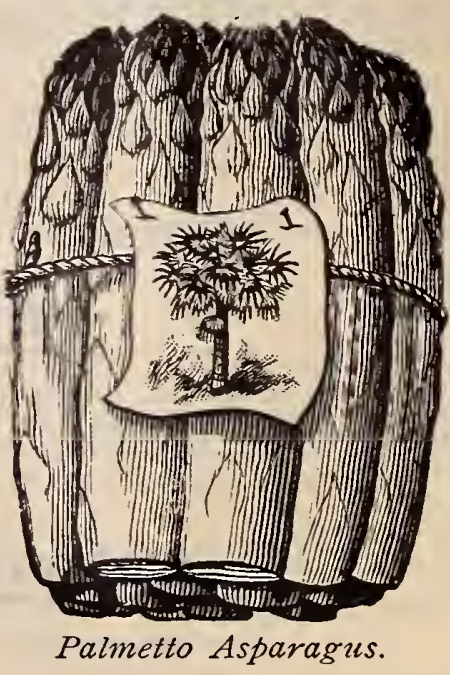

\section{BEANS, DWARF or BUSH} (Bujd Bofinen)

Beans are among our most valuable farinaceous foods, and form a market stapl : everywhere. The seeds should not be planted before the ground becomes light and warm, in favorable seasons usually about the first of May. Bush Limas should not be planted so early as other sorts, as Limas are particularly sensitive to cold and damp. The soil should be rich and mellow, and the seeds scattered about 3 inches apart in drills from 3 to $3^{1 / 2}$ feet apart, and covered about 2 inches deep. The plants will need frequent hoeing, but should never be cultivated when the leaves are wet with dew or rain, as this will cause them to rust. Successive sowings made at intervals of about two weeks until the middle of July will give a plentiful supply of beans all season. One quart of seed will sow roo feet of drill; 2 bushels will sow an acre.

Golden Wax Bean.

For Beans sent by mail, add postage at the rate of $8 \mathrm{cts}$. per pint, I5 cts. per quart

WAX, or YELLOW=PODDED BEANS

Golden Wax. (Original strain.) A very popular variety, more generally cultivated than any other sort, and in our trials it has proved itself superior in all respects to the so-called Improved Golden Wax. Finer pods, better color and more tender. The vines are hardy, productive; pods long, straight, flattish, very fleshy and wax-like, and of the best quality. The beans are small, oval, white, shared with purplish red. Qt. 30 cts., 1/2pk. $\$ 1$, bus. $\$ 7.00$. 
WAX BEANS, continued

Currie's Rust-Proof Wax. A valuable Bean, from the fact that it seems to be "rust-proof," after having been tested for several years with other Beans which rusted badly. Qt. 30 cts., $1 / 2 \mathrm{pk}$. $\$ 1$, bus. $\$ 7$.

German. The pods are yellowish, almost transparent; flesh tender and stringless; seeds black when ripe. Qt. $30 \mathrm{cts}$, , $1 / 2 \mathrm{pk}$. \$1, bus. $\$ 7$.

Davis Kidney Wax. Pods long, between flat and round, clear waxy in color; seeds pure white; early as Golden Wax. Flavor and eating qualities excellent. Beans pure white, and excellent for canner's use. Qt. 30 cts., $1 / 2 \mathrm{pk}$. $\$ \mathrm{I}$, bus. $\$ 750$.

Golden-Eyed Wax. As remarkable for its beauty of pod and vine and manner of growth as for its freedom from rust and blight The plant is rapid and vigorous in growth, yielding an early and abundant crop of beautiful golden yellow pods. Qt. 25 cts., $1 / 2$ pk 85 cts., bus. $\$ 6$.

Wardwell's Kidney Wax. A most excellent early variety, widely grown and deservedly popular. Pods creamy yellow, long, broad, flat, brittle and stringless; beans kidney-shaped, white, shaded with purplish brown; vines productive, strong and upright in growth. Qt. 35 cts., $3 / 2 \mathrm{pk}$. $\$ 1.25$, bus. $\$ 8$.

\section{GREEN=PODDED BUSH BEANS}

Improved Red Valentine. The leading, and by far the most generally grown green-podded Bush Bean. Hardy and vigorous; upright in growth,

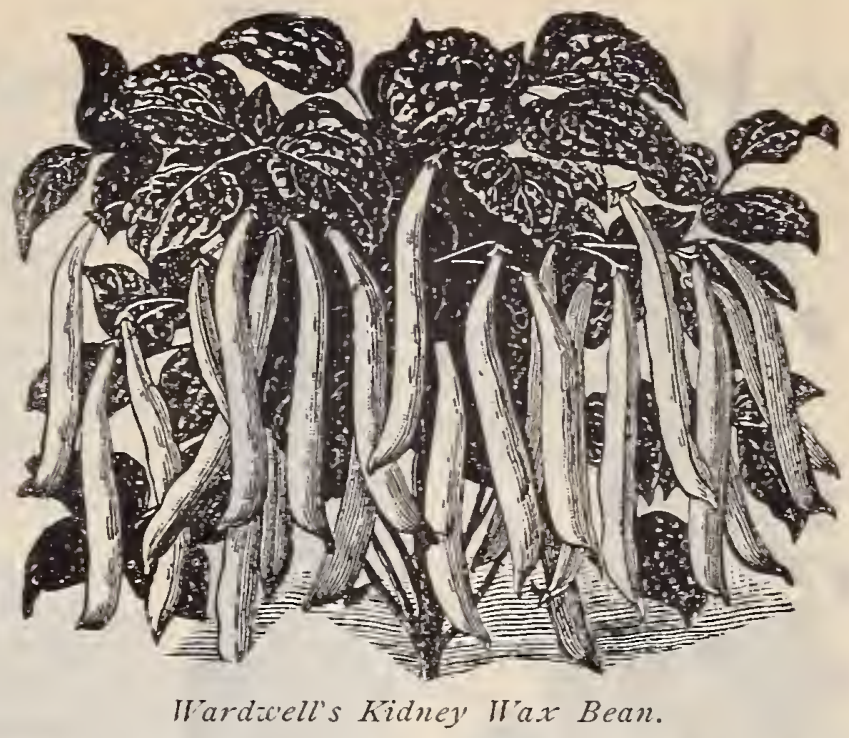

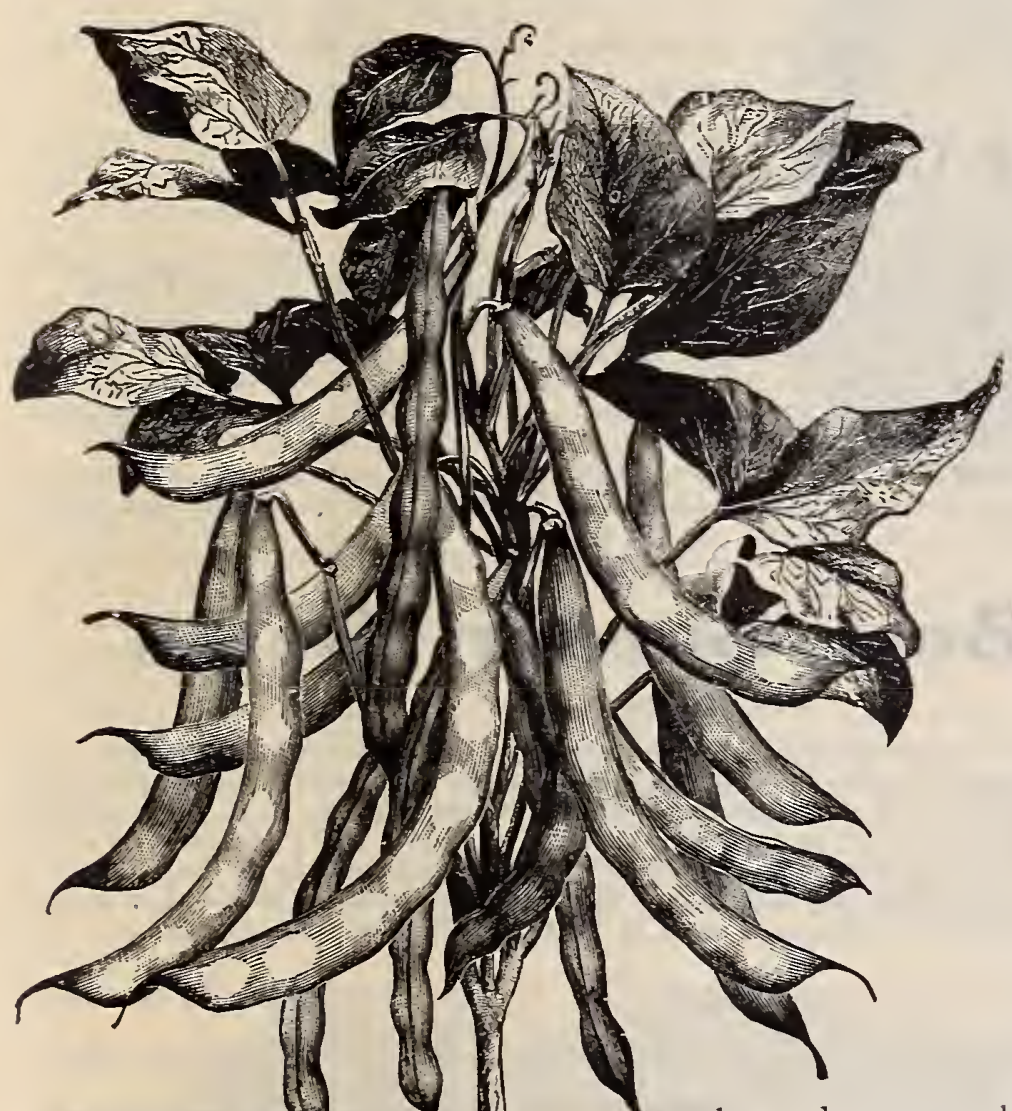

pods being well held up from the ground; early and remarkably uniform in ripening, making it very desirable for market-gardeners, as a large proportion of the pods can be secured at one picking; pods round, thick and solid, tender, and of fine flavor. This strain of Talentine is earlier than any we have ever tested, and more uniform in ripening, with almost entire absence of flat pods. Qt. $25 \mathrm{cts} ., 1 / 2 \mathrm{pk}$. 75 cts., bus. $\$ 4.50$.

Long Yellow Six Weeks. Valuable on account of its extra earliness and productiveness. The pods are long and flat, and of good quality as long as they are tender. Qt. $25 \mathrm{cts}$., $1 / 2 \mathrm{pk} .65 \mathrm{cts}$, bus. $\$ 4$.

Mohawk, or Brown Six Woeks. Early and productive; pods large and coarse, yet of excellent quality. Qt. 25 cts., $3 / 2 \mathrm{pk} .75$ cts., bus. $\$ 4.50$.

Boston Favorite, or Goddard. Large, handsome red pods, tender and fine for use as snaps; seeds very large and of delicious flavor, whether used green or dry. The bushes yield heavy crops. Qt. $25 \mathrm{cts}$., $1 / 2 \mathrm{pk}$. $75 \mathrm{cts}$., bus. $\$ 5.00$

Burpee's Stringless Green Pod. Extremely early. hardy and productive; pods handsome and of fine quality. Qt. 30 cts., $1 / 2 \mathrm{pk}$. $\$ 1$, bus. $\$ 6$

Bwarf Morticultural. Furnishes green-shelled beans of fine quality; seeds rellowish white, with red splashes; large, oval, plump, easily shelled. Qt. $25 \mathrm{c} ! \mathrm{s} ., 1 / 2 \mathrm{pk} .75 \mathrm{cts}$, bus. $\$ 5$.

Low's Champion. Very productive, with stringless, large, green, flat pods. Excellent either as a string or shell Bean. Qt. 25 cts., $1 / 2 \mathrm{pk}$. 75 cts., bus. $\$ 5$.

\section{BUSH LIMA BEANS}

Fine crops of delicious Limas are now grown without poles.

Burpee's Bush Lima. This Bean has become immensely popular. The plants come true from seed, and the dwarf habit has become well fixed. They grow into splendid hranching, circular bushes Is to 20 inches high and 2 or 3 feet across. The strong constitution of the plant is shown in its large, deep green, leathery leares, as much as in its enormous yield of thick, broad, handsome pods, which are as large and well filled as those of the Pole Limas; as many as 200 pods have been counted on a single plant. Identical in size and flavor with the Pole Limas, having the same rich, buttery taste, and Improved Red Valentine Bean. Identical in
Limas, having the
many to that variety. Qt. $30 \mathrm{cts}$., $1 / 2 \mathrm{pk}$. $\$ \mathrm{I}$, bus. $\$ 7$.

preferred by many to that variety. Qt. $30 \mathrm{cts}$., T/2pk. $\$ \mathrm{I}$, bus. $\$ 7$. Dreer's, or Kumerles abun lance. The beans are crowded thickly in the pods, and the seeds are thick, sweet and succulent. Qt. 30 cts., $1 / 2 \mathrm{pk}$. $\$ 1$, bus. $\$ 7$.

Henderson's Bush Lima. Two weeks earlier than the Pole Limas, and the bushes bear long and continually; the beans are of the small Sieva type. Qt. $30 \mathrm{cts}$., $1 / 2 \mathrm{pk}$. $\$ \mathrm{r}, \mathrm{bus} . \$ 7$.

\section{POLE, or RUNNING BEANS (Stangen Bohnen)}

Pole Beans are not so hardy as the Bush sorts, and should be planted several weeks later. when danger from frost is over. Plant the seeds in slightly raised hills 3 to 4 feet apart, four or five seeds to the hill. The Limas are especially tender, and the rule for late outside planting with them is rigid. Painstaking cultivators, who are usually the most successful, plant them eye downward, after setting stout poles for every hill. A quart of Limas will plant about roo hills a quart of the small sorts about 200 .

Goiden Cluster. Productive, early; plump, tender, yellow pods from 6 to 8 inches long, of fine flavor; remains fit for use a long time; vines bear continuously. Qt. $35 \mathrm{c}$., $1 / 2 \mathrm{pk}$. $\$ 1.25$.

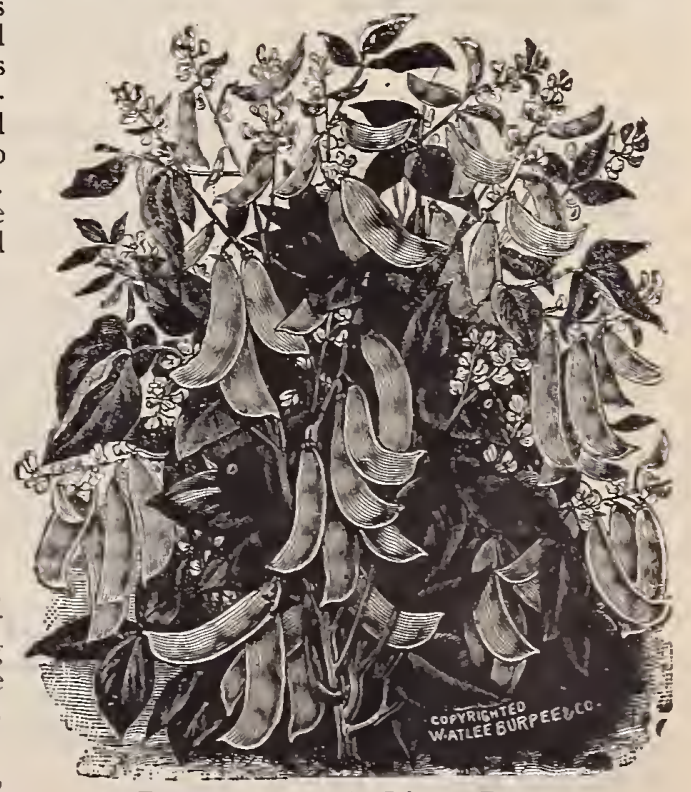

Burpee's Bush Lima Bean. 
POLE, or RUNNING BEANS, continued

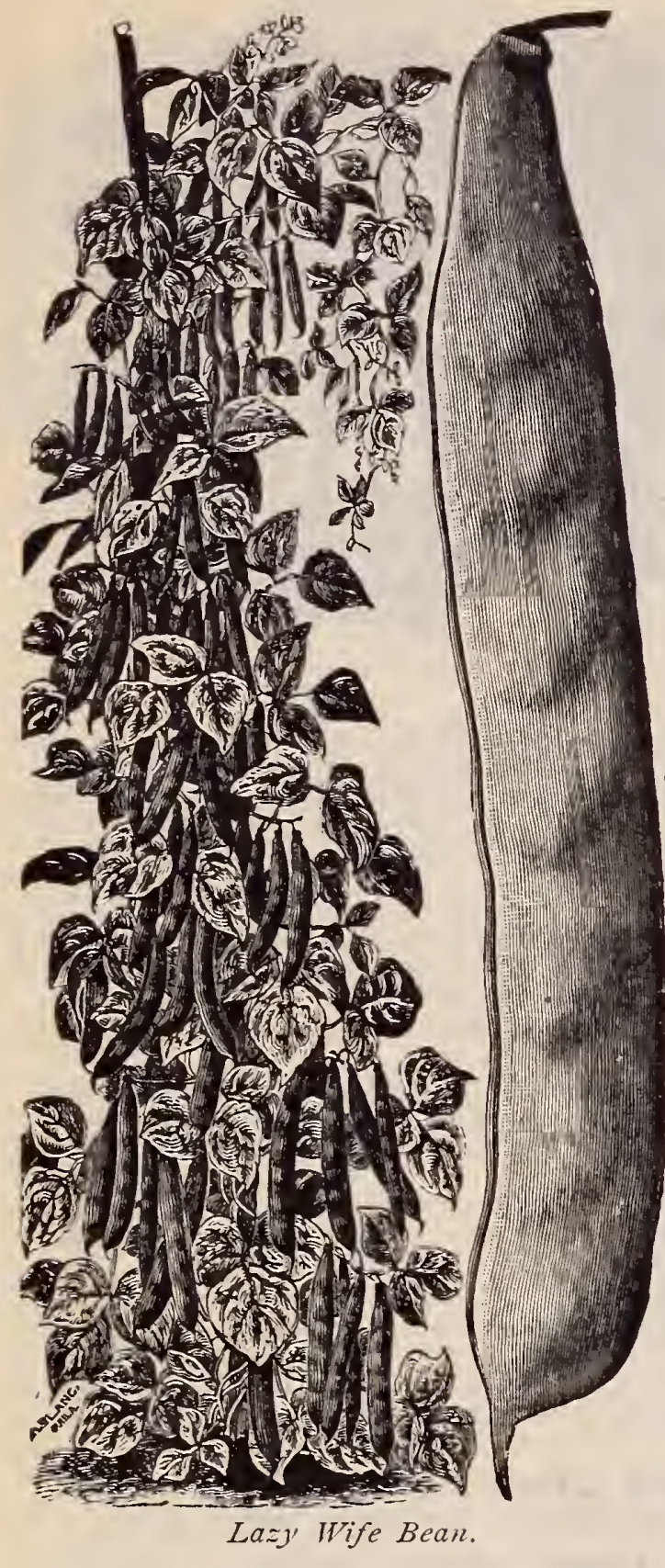

Lazy Wife. Popular and productive; pods green, 4 to 6 inches long, broad, thick, fleshy and entirely stringless; of rich, tender quality. Each one contains from 6 to 8 plump, round, white beans, which are excellent for winter use; late in maturing, and one of the best of this type of Beans. Qt. 30 cts., $1 / 2$ pk. $\$ 1$.

Old Homestibad, or Improved Kentucky Wonder. Excellent, very productive; pods a silvery green color, large, and entirely stringless. Qt. $30 \mathrm{cts}, 1 / 2 \mathrm{pk}$. $\$ \mathrm{I}$, bus. $\$$.

Golden Carmine Hortlcultural. Beans and pods much larger than the ordinary Horticultural. See page 3. Qt. 40 cts., $1 / 2 \mathrm{pk}$. $\$ 1.25$

Horticultural, or Cranberry. Good as a shell Bean, either green or dry; beans large, spotted with red; of good flavor; very productive. Qt. $30 \mathrm{cts}, 1 / 2 \mathrm{pk}$. $90 \mathrm{cts}$., bus. $\$ 6$.

Scarlet Runner. Very ornamental, free climber, with bright scarlet flowers. Qt. 35 cts., $1 / 2 \mathrm{pk}$. $\$ 1.15$

White Runner. Large, white flowers; often planted with the scarlet variety; the effect is very fine. Qt. 35 cts., $1 / 2 \mathrm{pk}$. $\$ 1 . \mathrm{I} 5$

\section{POLE LIMA BEANS}

King of the Garden. An improvement on the Large

Lima, with large beans and pods and more productive habit.
When not too closely planted, the vines set beans early, and Golden Carmine Hortlcultural is the Bean for Market-Gardeners.

bear continuously until frost; only two vines should be allowed to a hill. Qt. $30 \mathrm{cts}$., $1 / 2 \mathrm{pk}$. $\$ 1$, bus. $\$ 7$.

Extra-Early Lima. A standard variety; the beans are large and buttery in flavor. Qt. 30 cts., $1 / 2 \mathrm{pk}$. $\$$ I, bus. $\$ 7$.

Dreer's Improved Lima. Early and productive; beans thick and rounded, tender and good. Qt. $30 \mathrm{cts} ., \mathrm{s} / 2 \mathrm{pk}$. $\$ \mathrm{I}$, bus. $\$ 7$.

\section{BRUSSELS SPROUTS}

\section{( $\Re$ ojenfohl)}

This is a very delicate-flavored species of cabbage, with small, solid, tender heads clustered thickly along the main stem. When properly cooked and seasoned they are delicious, melting away in the mouth like fine cauliflower. The seed should be sown in April or May, and the plants cultivated like cabbage ; they are very hardy, and the heads are improved by frost. In some sections where good cabbage cannot be grown, these Sprouts succeed admirably. All gardeners should give them a trial; they should be a favorite vegetable. An ounce of seed will produce 3,000 plants.

Dwarf Improved. Plants of this variety are dwarf, with small, solid, tender heads, growing very close together along the stem. A standard sort of exceptional flaror when touched by frost. Oz. 25 cts., $1 / 41 \mathrm{~b} .65 \mathrm{cts}$., 1b. $\$ 2$.

\section{The Best Garden Beets}

\section{(Salatriiben)}

Sweet and juicy Beet roots, when young and tender, form very tempting salads and pickles. The soil best suited to the Beet is a deep and light, rich, sandy loam. For very early crops, the seed of Crosby, or some similar sort, is sown in hotbeds, and the seedlings are transplanted to the open ground as soon as it is warm enough. For main crop or early Beets, the seed is sown outside, as soon as the soil is in good condition, in drills from is to 24 inches apart, and covered about one inch deep: the plants are thinned to stand to inches apart in the rows. For winter crops, sow seed in July, in drills as for early Beets. An

ounce of seed will sorv 50 feet of drill; 5 to 6 pounds an acre.

CROSBY IMPROVED. This strain is an improvement on the Egyptian Blood Turnip. The flesh is fine-grained, siveet and tender; the color is deep, rich red. Oz. Io cts., $1 / 7 \mathrm{lb}$. 25 cts., $1 \mathrm{~b}$. 75 cts.

Detroit Dark Red. Early maturing, and of splendid shape and color. Tops small, upright growing, so that the rows may be close together; leaf-stems and veins dark red, blade green; roots globular or ovoid, peculiarly smooth; color of skin dark blood-red; flesh bright red, zoned with a lighter shade, very

, tender and sweet, and remaining so fir a long time. Oz. 10c., 1/16. 20c., 1b. 6oc.

crimson Globe. This handsome variety is especially adapted for light soils; very early; ; its round shape and rich color make it a desirable market variety. Oz. io cts., b. 25 cts., 1 b. 60 cts.

Dewing's Blood Turnip. One of the best main-crop and late sorts. The roots are long. round and smooth. with blood-red flesh. Oz. Io cts., 1//1b. $23 \mathrm{cts}$., 1b. $50 \mathrm{cts}$.

Edmand's Blood Turnip. Round, smooth, and uniform in shape, and seldom growing too large; unusually sweet. Oz. Io cts., I/4 lb. $20 \mathrm{cts}$., 1b. $60 \mathrm{cts}$.

ECLIPSE. Roots are globe-shaped, deep red, with sweet, fine-grained flesh, hich remains tender a long time. Oz. IOc., $1 / 1 / 1 \mathrm{~b} .20 \mathrm{c}, 1 \mathrm{~b} .60 \mathrm{c}$.

Arlington Favorite. A variety closely resembling Dewing's, as originally introduced. Of medium size and dark, rich color; excellent. Oz. IOc., 1/41b. 20c., 1b. 6oc. Long Smooth Blood. Half-long, deep red roots; flesh firm, juicy and tender. Oz. Io cts., $1 / 4 \mathrm{lb} .20$ cts., 1b. 60 cts.

Swiss Chard Sea-Kale Beet. Grown for its tender, succulent tops, which are prepared for the table like spinach or asparagus. Oz. Io cts., I/ 1 lb. $25 \mathrm{cts}$., $1 \mathrm{~b} .75 \mathrm{cts}$.

\section{BROCCOLI (Eprojientogi)}

Requires the same treatment as cauliflower. The heads are tender, white and deliin flavor. An ounce of seed will produce about 3,000 plants.

White Cape. Heads creamy white, of medium size, compact; sure to form, and delicate in flaror. Oz. 30 cts.

Purple Cape. Like the above, except that the heads are larger and of a purplish color. Oz, $30 \mathrm{cts}$.

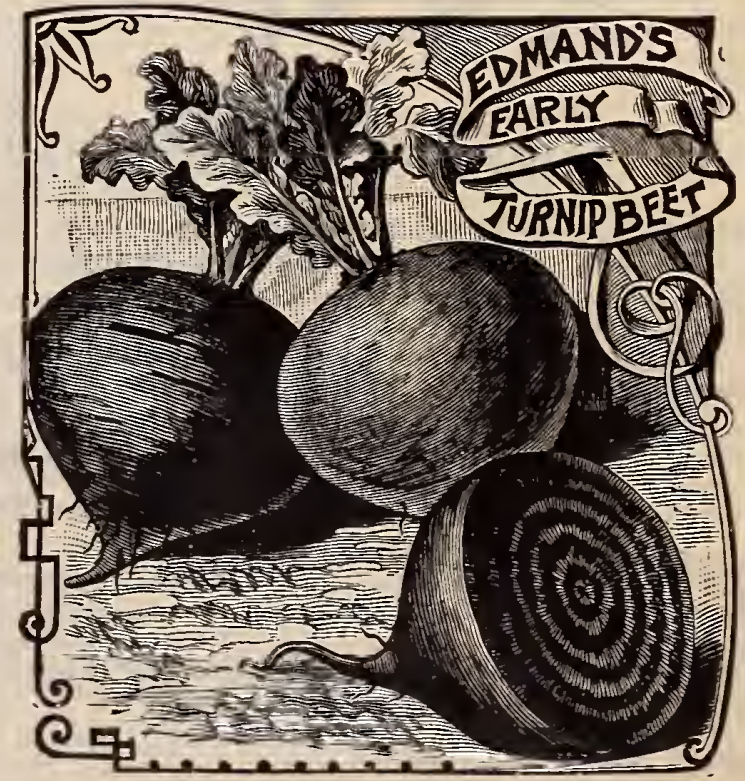




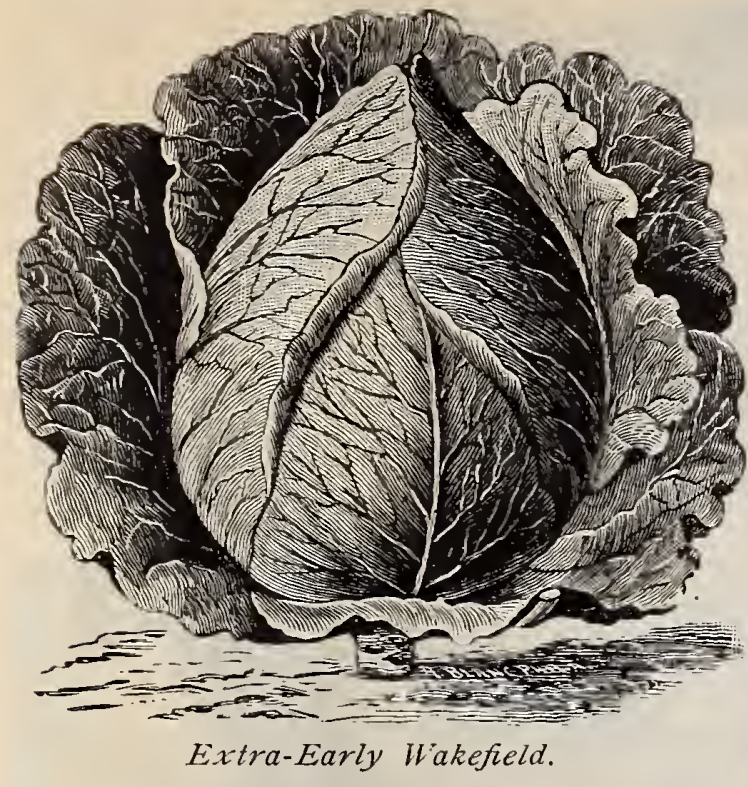

Extra-Early Jersey Wakefield. The best early variety of Cabbage. Heads of medium size, pyramidal, pointed, firm and solid, with few outside leaves; they are very uniform in shape, size and time of maturing, and are of good quality. Oz. 25 cts., r/4lb. 65 cts., 1b. $\$ 2$.

Large Jersey Wakefield, or Charleston. A selection from the above, and ten days later. with heads rounder and twice as large. A fine variety, and worthy of general cultivation. $\mathrm{Oz}$ $25 \mathrm{cts}$., $1 / 4 \mathrm{lb} .65 \mathrm{cts}$, 1b. $\$ 2$.

Henderson's Succession. About a week later than Early Summer, with heads much larger. Good for early or late use. Oz. $25 \mathrm{cts}$., I/4 lb. 65 cts., 1b. $\$ 2$.

Fenderson's Ear1y Summer. than the Wakefield, and twice its size. The heads are large, solid, roundish flat, of good flavor, and stand a long while after maturity without bursting. The outer leaves of the plant grow close and upright, so that they may be planted close together and thus save space. Oz. $20 \mathrm{cts}$., $1 / 41 \mathrm{~b} .65 \mathrm{cts}$., $1 \mathrm{~b} . \$ 2$.

Early Winnigstadt. Conical or "sugar loaf" heads of fair size. It is one of the best summer Cabbages, and if sown too late, good for fall. Oz. 20 cts., 1/4 lb. 50 cts., Ib. \$1.50.

All-Seasons, or Vandergaw. Noted for its superior quality and delicacy of flavor. Almost as early as Henderson's Early Summer; heads larger and quite thick through; good for early and late crops. Oz, 25 cts., 1//1b. 75 cts., 1b. $\$ 2$.

Select Large Late Flat Dutch. An excellent keeping variety ; the old standby for main crops and still more extensively grown for main crops than any other sort. Heads large, broad, roundish, flat, solid and of good quality. A fine sort. Oz. 20 cts., $1 / 1 \mathrm{~b} .65$ cts., 1b. $\$ 1.75$.
Danish Ballhead. Heads are thick, round, of medium size and about as hard as a rock. The stump averages longer than with our native sorts. For best results for late marketing, plant about ten days earlie: than the common Drumhead on land liberally manured. Oz. 25 cts., I/41b. 75 cts., 1b. $\$ 2.50$.

Improved American Drumhead Sayoy. The best Cabbage of this fine class. Heads large, solid, with finely curled, close wrinkled leares, of cauliflower flavor; a good-keeping, fine winter Cabbage. Oz. 25 cts., $1 / 1 \mathrm{lb} .65$ cts., $1 \mathrm{~b} . \$ 2$.

Red Dutch. This variety is widely grown for pickling. Oz. 25 cts., 1/4lb. 65 cts., 1b. $\$ 2$.

Warren's Stone-Mason. A greatly improved type of Stone-Mason, being earlier, rounder and mere solid. $\mathrm{Oz}$ 25 cts., $1 / 41$ b. 65 cts., lb. $\$ 2$ Cabbage is one of the gardener's most important crops, the value of which depends
largely upon the quality of the seed used as upon the soil, climate and culture. They are usually sown early in the spring in hotbeds, and later in the open ground for main the winter, they may be set out in rows in fall. Seed sown in hotbed or greenhouse about February i5 will give plants large enough to transplant into hotbeds about MIarcli remove the glass for part of the day to harden them for final transplanting into the open ground, increasing the exposure daily until April Io or 20 , when the final transplanting For late crops, sow seed in April or Nay, and transplant in July, setting the plants in the ground up to the first leaf, and $2 \times 3$ feet apart. It is important that the plants should planting must be done on a dry, hot day
the roots should be "puddled" the soil must be plowed deep and made very rich. The plants need thorough them should be kept in check with remedies which seem most efficacious in the grown for a number of years in the same ground, on account of club-root.

\section{CHICORY}

\section{(Etctiorie)}

The seed should be sown in early spring, in good, mellow soil, and in drills half an inch deep.

Large-Rooted Magdeburg, or Coffee. The roots form the Chicory of commerce; the leaves when blanclied make an excellent salad. Oz. I5 cts., 1/41b. 35 cts., lb. \$1. 


\title{
Cauliflower
}

\author{
(Blumenfohl)
}

Fine cream-white heads of Cauliflower seldom fail to bring a good price in any market. A proper succession of varieties affords this very popular and desirable vegetable through a long period of the year.

Menderson's Early Snowba11. This is the earliest and most popular variety in cultivation and is largely grown everywhere, both for forcing and early crops outside. The plants are dwarf and sure heading; of fine, delicate flavor. $1 / 40 z .65$ cts., oz. $\$ 2$.

Extra-Early Erfurt. We believe ours to be the finest strain of Erfurt ever offered. The plants may be depended upon to form large, firm, white heads very early. The variety compares very favorably with Early Snowball. $1 / 4 \mathrm{Oz} .65$ cts., oz. $\$ 2$.

Thorburn Gilt-Edge, Large, heavy sort: undoubtedly the best and surest of all the sorts now in cultivation. $1 / / 4 \mathrm{Oz} .75 \mathrm{cts}$., oz. $\$ 2.50$.

Veitch's Autumn Giant. I'hite, large, firm heads, which are well protected by large leaves. $1 / 4 \mathrm{Oz}$. 20 cts., Oz. $75 \mathrm{cts}$.

HOW TO GROW FINE CAULIFLOWER. The general outlines of culture for Cauliflower and cabbage are essentially the same, but to the former extra care given in the way of supplying fertilizers and moisture well repays the gardener. Sow the seeds for early and late crops as directed for cabbage, but do not set the early plants in the field too soon, for if too much stunted by serere frosts they begin to form heads before they are strong enough to develop them well Plants which have not headed before winter sets in may be stored in a cool cellar or coldframe, and will form heads there without any further attention. A deep, loamy soil, with a substratum of moisture during dry weather, is most suitable for the Cauliflower. Market-gardeners find this one of their most profitable crops, and amateurs who undertake its culture find it easy; but it is a crop in which carelessness or neglect will interfere with the best results. An ounce of seed will produce about 3,000 plants.
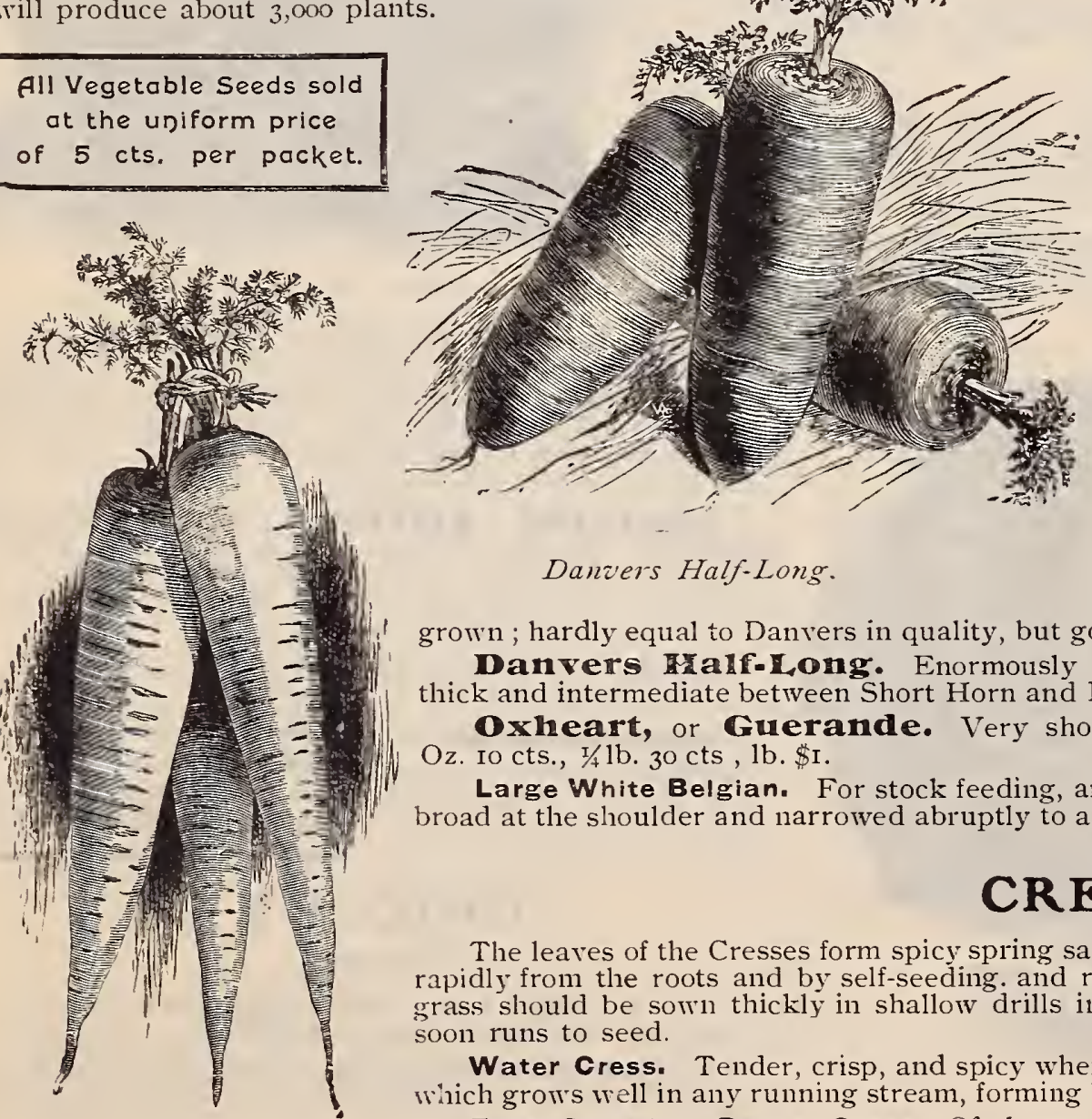

Carrots succeed best on light, sandy loam, which, preferably, should have been well fertilized the previous year, as fresh manure often causes the roots to gron pronged and misshapen. Sow the seed as early in spring as the ground can be prepared, firming the soil down over it. If sown late it should be soaked in tepid water, then mixed with plaster or sifted coal ashes, and sown on freshly prepared soil. Quick germination and rapid growth are necessary. An ounce of seed will sow roo feet of drill; four pounds wiil sow an acre.

Early Gcarlet Morn. Best for forcing and early cutdoor crops; can be grown in shallow soil, and requires no thinning if sparingly sowin; as the roots are used when young for cooking. They are about 3 inches long, and of very good quality. Oz. io cts., $1 / 41 \mathrm{~b}$. 30 cts., lb. \$I.

Chantenay. Handsome roots, broad-shouldered, and Danvers Half-Long. smooth and more uniform than in the Danvers: Of superior flavor. Oz. Io cts., 1/41b. $30 \mathrm{cts}$., 1b. \$I.

Improved Long Orange. Extensively grown ; hardly equal to Danvers in quality, but good, and heavy in yield. Oz. Io cts., $1 / 1 \mathrm{lb} .25 \mathrm{cts}, 1 \mathrm{~b} .8 \mathrm{c}$.

Danvers Kalf-Long. Enormously productive; adapted to all soils. The roots are smooth, thick and intermediate between Short Horn and Long Orange in form. Oz. Io cts., r//1b. $30 \mathrm{cts}$., 1b. \$I.

Oxheart, or Guerande. Very short, smooth and thick, and well adapted to shallow soils. Oz. Io cts., T/4lb. 30 cts, $1 \mathrm{~b}$. \$i.

Large White Belgian. For stock feeding, and especially suited to shallow soils. Roots white-fleshed, broad at the shoulder and narrowed abruptly to a point. Oz. Io cts, I//1b. $25 \mathrm{cts}$., 1b. $70 \mathrm{cts}$.

\section{CRESS (Irefie)}

The leares of the Cresses form spicy spring salads, and are also used for garnishing. The plants increase rapidly from the roots and by self-seeding. and require little care after they become established. Peppergrass should be sown thickly in shallow drills in early spring, and at intervals for continual supply, as it soon runs to seed.

Water Cress. Tender, crisp, and spicy when young. Plant of prostrate habit. A perennial aquatic, which grow's well in any running stream, forming large beds of leaves. Oz. 40 cts., I/4 lb. \$1.25, Ib. \$4.

Extra-Curled, or Pepper-Grass. Of pleasant, pungent flaror: the leaves can be cut several times. The p.ants grow well in almost any soil, and require little care. Oz. Io cts., 1/41b. 20 cts., lb. 50 cts. 


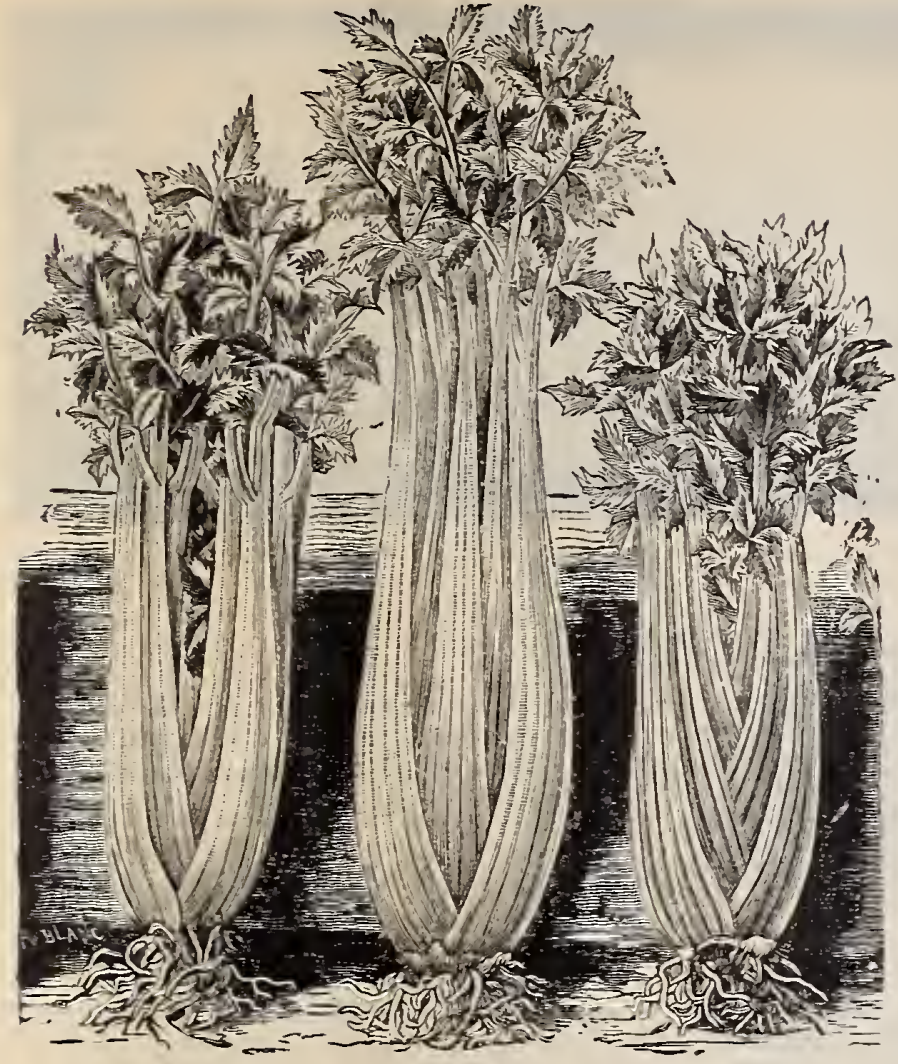

White Plume, Giant Pascal and Paris Golden.

\section{Celery Seed

\author{
(eellerie)
}

Celery can be grown in any soil, but is finest on deep, mellow bottomland. Seed for early crops should be sown in hotbeds about Jlarch I5; if sown too early, the plants are apt to run to seed after being transplanted. The plants may either be thinned to give them room to grow, or transplanted to another bed to grow until it is time to plant them in the open ground. For the main crop, seed should be sown in the open air as soon as the soil and air are warm enough. They should be covered very lightly, or merely pressed into the earth with a board, if the soil is fine and mellow. The seed-bed must be kept free from weeds and well watered in dry weather. When the plants are large enough, transplant them to shailow trenches or furrows from 4 to 6 feet apart, according to the variety grown, setting the plants 6 inches apart in the rows, and pressing the soil firmly around them. They must be well cultivated and kept free from weeds until ready for blanching, which consists in drawing earth up to the stalks at intervals of about two weeks, until all but the tops of into the center of the plant, as this would cause them to rust or decay. Celery may be kept for winter use in pits or cellars, or in deep, narrow trenches, in a dry situation; the latter must be covered with boards, with sufficient soil and manure on top to keep out the frost, leaving openings for ventilation in mild weather at short distance. An ounce of seed will produce about 2,000 plants.

White Plume. A very popular market variety; easily blanched, and one of the handsomest sorts grown. In large plants the stalks, hearts and inner leaves become white without any blanching. Good for fall and summer crops, but does not keep well enough for winter use. Its fine appearance sells it readily in market. For early market use, however, few varieties surpass it. Oz. 25 cts., $1 / 1$ lb. 75 cts., 1b. $\$ 2$.

Pink Plume. Self-blanching; stalks are suffused with pink, and possess the crispness, rich, nutty flavor and long-keeping-characteristics for which red Celeries are noted. Oz. 25 cts., $1 / 4$ lb. 75 cts., 1b. \$2.50.

Giant Pascal. The stalks are remarkably broad and thick, and about 2 feet high, ret blanch quickly with but slight banking: their rich, nutty flavor is en'irely free from any bitter taste, and they are tender, crisp and stringless; a valuable sort for both early and late use. Oz. $25 \mathrm{cts}$., $1 / 41 \mathrm{~b} .75 \mathrm{cts}$., lib. $\$ 2$.

Paris Golden. Self-blanching; has stalks of be zutiful golden yellow, equal in quality to those of any variety grown. Plants semi-dwarf and vigorous, with large, ribbed and rounded stalks, which are quite crisp and tender. Distinguished when quite small by the distinct yellowish green of its leaves. One of the best and handsomest of Celeries. See page 3. Oz. $50 \mathrm{cts}$., 1/41b. \$I.50, 1b. \$6.

Boston Market. The dwarf, branching variety grown so extensively about Boston. It is unequaled br any other sort, being solid, crisp and of excellent flavor; its compact, dwarf habit allows closer planting, and requires less earthing up than taller sorts. Oz. $30 \mathrm{cts}$., $1 / 41 \mathrm{~b}$. $\$ \mathrm{I}, 1 \mathrm{~b} . \$ 3$.

WE USE THE UT.
MOST CARE TO HAVE
OUR CELERY SEED
PURE.

\section{CELERIAC, Or TURNIP=ROOTED CELERY (finollen Eellerie)}

The seed should be sown in early spring, in light, rich soil, the seedlings transplanted in May, and watered freely in dry weather. They will be ready = for cooking in October, and may be preserved for use during winter in dry sand. Celeriac is said to be as fine a nerve tonic as celery, and can be grown in many sections where celery culture is practically impossible. The roots have almost the same flaror as the crispest white celery stalks, and do not require half so much care in banking, while they keep perfectly with no more care than
a crop of turnips-much longer than celery stalks can be kept in good condition. An ounce of seed will produce about 5,000 plants.

Prague Giant. The roots of this variety are very large and smooth, with no side roots, and sell better in market than those of almost any other sort offered. When young they are quite tender
and marrow-like, having a very fine flavor, and

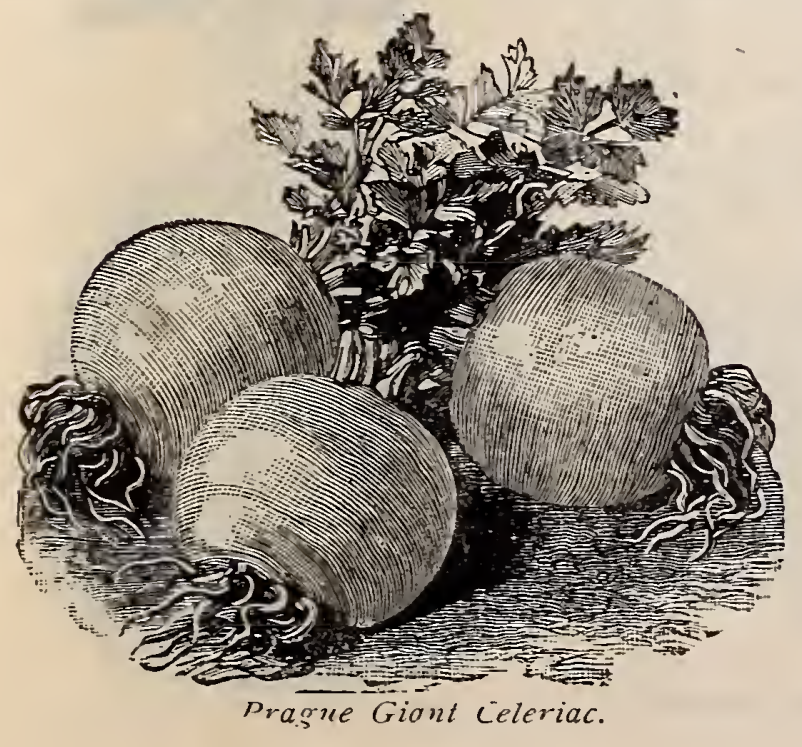
and marrow-like, having a rery fine flavor, a
cooking quickly. Oz. 25 cts., $1 / 1 \mathrm{l}$. 85 cts., $1 \mathrm{~b} . \$_{3}$.

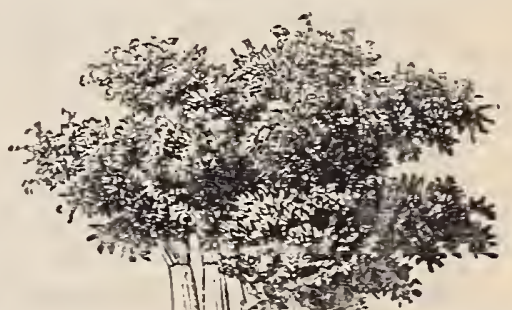

\section{CORN SALAD, or FETTICUS (Ramnter Galat)}

The leaves are used during winter and spring as a salad. Sow the seed thickly in shallow drills in September, and firm the soil well down above it, if the weather is dry. The plants will require no culture beyond keeping them free from weeds in northern climates thershould be given a light covering of straw in winter. The richer the soil the finer the flavor of the leaves. In some sections of country this salad is highly appreciated. An ounce of seed will sow a bed zo feet square.

Large-Seeded. The variety now most generally cultivated. Oz. IOc., $1 / 1 \mathrm{lb}$. 25c., 1b. $75 \mathrm{c}$

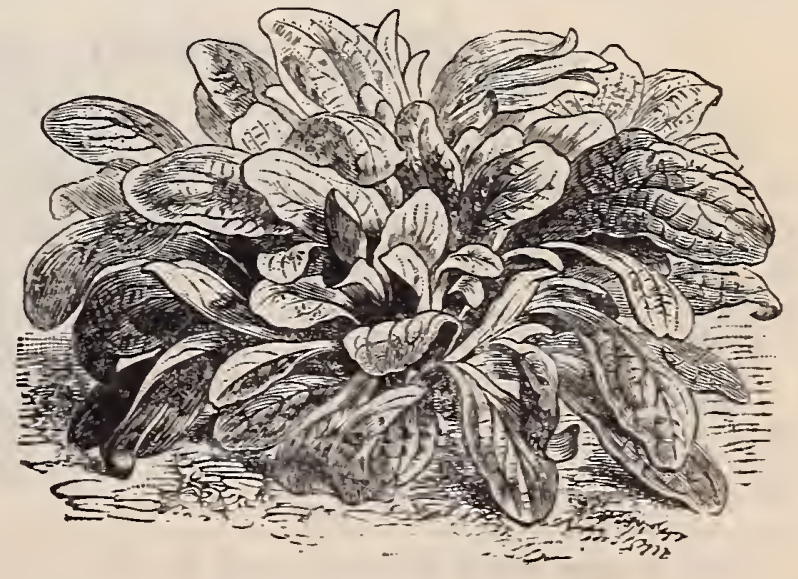

Corn Salad. 


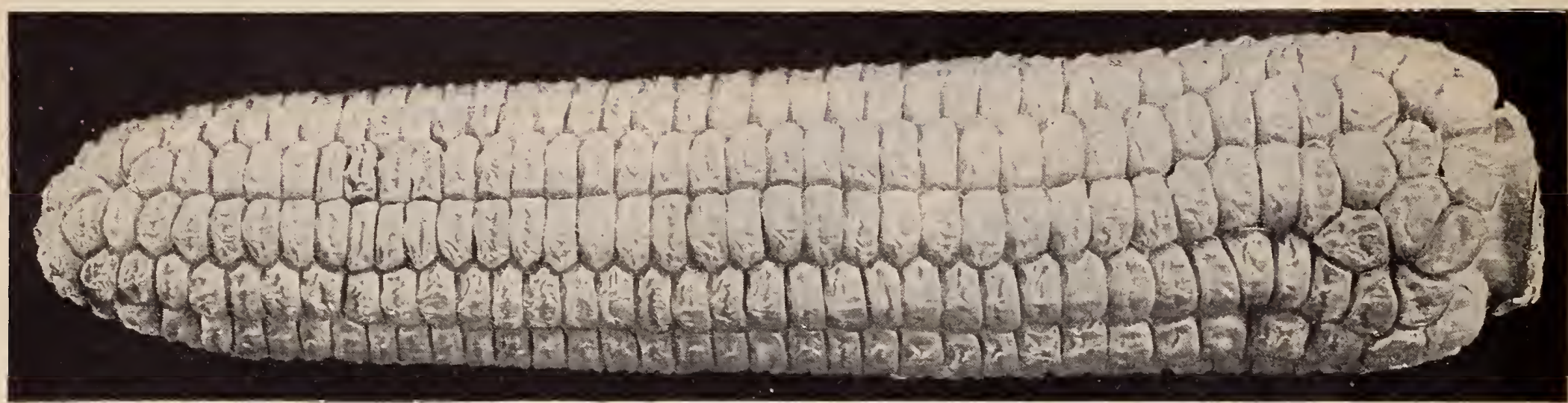

Judge Bliss Sweet Corn.

\section{Corn, Swreet or Sugar (mai}

It is our opinion, after several years of testing, side by side, that eastern-grown Sweet Corn is far superior to western in sweetness, and also retains this necessary quality for much longer time. This is also the opinion af many of our local market-gardeners. Our entire stock for this season we guarantee to be New England-grown. This delicious vegetable may be enjoyed from early summer until frost if the proper varieties are selected and planted for succession every two weeks from May until the middle of July. If the seed is planted too early, before the ground becomes warm, it is liable to decay. Plant in hills 3 or 4 feet apart each way, 5 or 6 kernels to a hill; or in rows 4 or 5 feet apart, scattering the seeds thinly in the rows. The taller-growing the varietr, the richer should be the soil and the wider the space allowed for development.

Add $10 \mathrm{cts}$. per quart on Corn, If to be sent by mail.

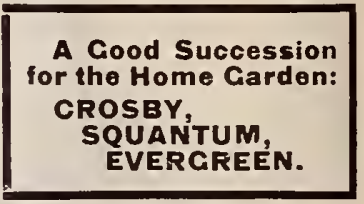

\section{EARLY VARIETIES}

Cory. The earliest variety : stalks short; ears set quite low, of fair size, and well filled with large yellowish grains. Qt. $25 \mathrm{cts}$., $1 / 2$ pk. 65 cts., bus. $\$ 4$.

Early White Cory. Identical with Cory, except in color, grains and cob being pure white in this sort, thus removing an objection which has sometimes been made to Cory. Qt. $25 \mathrm{cts}$., 1/2 pk. $65 \mathrm{cts}$., bus. $\$ 4$.

Metropolitan. A new early sort, only a few days later than the Cory; ears are about 9 mches in length, Io to 2 rowed, large deep kernels; very sweet. It is an excellent variety for market-gardeners. Qt. $25 \mathrm{ct}, 1 / 2 \mathrm{pk} .65 \mathrm{cts}$, bus. $\$ 4$.

Quincy Market. This holds the same rank among early varieties as Potter's Excelsior does among the later sorts. It comes in just after the Cory and just before the Crosby, but is larger than either. Twelve-rowed. Qt. $25 \mathrm{cts}$., I/2 pk. $65 \mathrm{cts}$, bus. $\$ 4$.

\section{SECOND=EARLY AND GENERAL CROP}

Perry's Hybrld. A valuable early market variety. The ears are large and ready for use quite early; they contain from I2 to I6 rows of large, pure white grains. Stalks about 5 feet high, and bear 2 or more fine ears each. Qt. $25 \mathrm{cts}$., $1 / 2 \mathrm{pk} .65 \mathrm{cts}$., bus. $\$ 4$.

Early Crosby. Ears of medium length, good size, I2-rowed; filled with thick, sweet grains; but little later than Perry's Hybrid. The stalks are productive, vigorous and hardy. Qt. $25 \mathrm{cts} ., 1 / 2 \mathrm{pk}$. 65 cts., bus. $\$ 4$.

Stabler's Early. One of the earliest of the second-early class, following close after the Cory. The ears are very large for so early a sort, and very sweet. Qt. 25 cts., $1 / 2$ pk 65 cts., bus. $\$ 4$.
Judge Bliss. Last season we offered this new variety for the first time, and all who gave it a trial pronounced it excellent in every respect. Stock very short, owing to bad season. Qt. $25 \mathrm{cts}$., $1 / 2 \mathrm{pk}$. 85 cts., bus. $\$ 5$.

SQUANTUM SWEET. This is the very best Sweet Corn for table use. Our stock is perfectly pure, being grown by us from selected ears. Qt. $25 \mathrm{cts}$., $1 / 2 \mathrm{pk} .65 \mathrm{cts}$., bus. $\$ 4$.

Early Evergreen. One to two weeks earlier than Stowell's Evergreen. Qt. 25 cts., $1 / 2$ pk. 65 cts., bus. $\$ 3.50$.

Country Gentleman. Ears of good size, and well filled to the tips with deep, tender, white grains of delicious quality; ; cobs small; stalks productive, averaging 3 ears each. Superior in quality to any other variety. Qt. $25 \mathrm{cts}$., $1 / 2 \mathrm{pk}$. $75 \mathrm{cts}$., bus. $\$ 4.50$.

Stowell's Evergreen. The standard main-crop variety, grown more generally and on a larger scale than any other sort. Ears large, with deep, tender, sugary grains, and remain fit for use longer after maturity than any othe $r$ Sweet Corn. This is a very productive and hardy variety, adaptable either as an early or late sort, and fine for private gardens, market and canning. It holds its own very well beside all new sorts. Qt. $25 \mathrm{cts}$., $1 / 2 \mathrm{pk} .65 \mathrm{cts}$., bus. $\$ 3.50$.

Late Mammoth. Enormous size of ears, which frequently weigh from 2 to 3 pounds; the cobs are large, the grains flat, the quality very good. This is a very productive variety, and matures its ears a little later than Stowell's Evergreen. One of the best of the largeeared sorts. Qt. $25 \mathrm{cts}$., $1 / 2 \mathrm{pk}$. $65 \mathrm{cts}$., bus. $\$ 3.50$.

Bearsfoot. A late variety of extraordinary sweetness; large ears; very desirable for market. Qt. 25 cts., $1 / 2$ pk. 85 cts., bus. $\$ 5$.

Our Sweet Corn is all New England-grown.

\section{THE BEST EGGPLANT}

\section{(Eierpflanze)}

Sow the seed in hotbeds early in March, transplant to small pots, and plunge them in the same beds; this is to make them strong and stocky. They should not be planted out in rows until May or June, when the weather becomes warm and settled, as cool nights and wet weather will check thei growth. Set the plants in rows 3 feet apart each way, and give them thorough cultivation, drawin! the earth up to the stems when they are about a foot high; it is well to keep some plants in the hotbec for replanting. Repeated sowings are sometimes necessary, as the seed does not germinate freel without strong and uniform heat. In cutting the fruit, be careful not to injure the plants. An ounce of seed will produce 1,000 plants.

New York Improved Thornless. The leading market variety, strong and productive in habit. The fruits are deep purple, large and smooth, entirely free from thorns, and the flesh is white, tender and delicate-flavored The plant is robust and a good yielder on all rich soils. Oz. 40 cts , 1/4 1b. $\$ 1.25,1 \mathrm{~b} . \$+50$.

All Vegetable Seeds sold at the uniform price of 5 cts. per packet

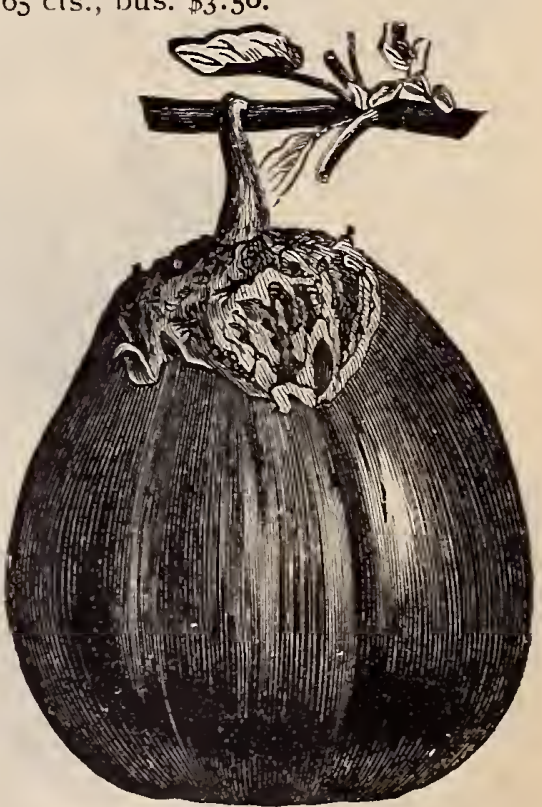

New York Improved Eggplant. 


\title{
Cucurmber
}

\author{
(ङ)urfe)
}

\section{ALL THE BEST SORTS FOR SALADS AND PICKLINC}

For general crops the seed cannot be planted in the open ground before the weather has become warm and settled and the ground mellow and light. Plant the seeds in well-enriched hills about 4 feet apart each way, and as soon as all danger from insects is over, thin the plants to leave 4 of the strongest in each hill. For succession, sow at intervals of every two weeks until midsummer. Extra early crops may be grown by planting the seeds in hotbeds in April, upon pieces of sod turned upside down, and removing these to hills in the open ground as soon as the weather is warm enough. For pickles, sow the seed from the middle of June until the middle of July. The vines bear longer if the fruits are gathered as soon as they are large enough; their strength is soon exhausted by ripening fruit. An ounce of seed will plant 50 hills; 2 pounds will plant an acre.

Rawson's White Splne. Grown by IV. W. Rawson, and sold by us under his seal. Oz. 30 cts., $1 / 4$ lb. $\$ \mathrm{I}, 1 \mathrm{~b} . \$ 4$.

Boston Picking. Very popular for pickles ; fruit smooth and symmetrical, but slightly pointed at the ends;

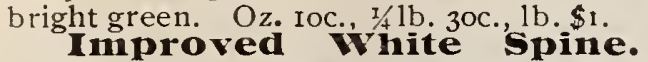
Early and productive, and suitable either for forcing or outdoor crops. Fruit of medium size, good shape, light green, with a few white spines on the surface. Oz. Ioc.

\section{$1 / 41 \mathrm{~b}$. 3 ) cts., 1b. $\$ \mathrm{I}$}

cumberiand. The best pickling sort yet introduced, being very handsome and productive, with flesh firm but very crisp and tender at all stages of growth; straight and symmetrical. Oz. IO cts., $1 / 4 \mathrm{lb} .30 \mathrm{cts}, 1 \mathrm{~b} . \$ \mathrm{I}$.
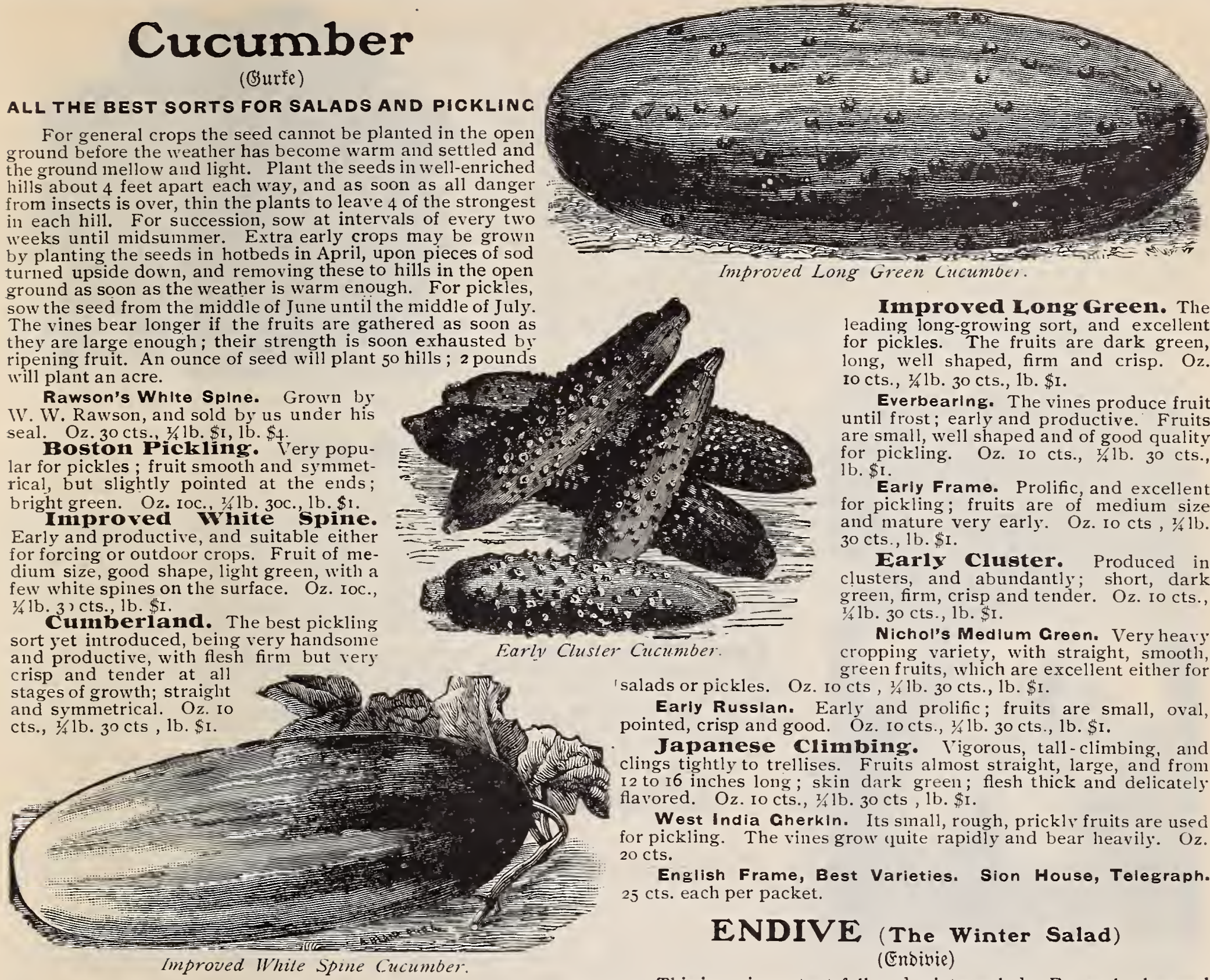

Improved Long Green. The leading long-growing sort, and excellent for pickles. The fruits are dark green, long, well shaped, firm and crisp. $\mathrm{Oz}$ to cts., $1 / 4 \mathrm{lb}$. $30 \mathrm{cts}$., lb. $\$ \mathrm{I}$.

Everbearing. The vines produce fruit until frost; early and productive. Fruits are small, well shaped and of good quality for pickling. Oz. Io cts., 1/4lb. $30 \mathrm{cts}$. 1b. \$I.

Early Frame. Prolific, and excellent for pickling; fruits are of medium size and mature very early. Oz. Io cts, $\pi / 41 \mathrm{~b}$. 30 cts., 1b. \$I.

Early Cluster. Produced in clusters, and abundantly; short, dark green, firm, crisp and tender. Oz. ro cts. I/41b. 30 cts., 1b. $\$$ I

Nichol's Medium Green. Very heavy cropping variety, with straight, smooth, green fruits, which are excellent either for salads or pickles. Oz. Io cts, 1/1/1b. 30 cts., lb. \$I.

Early Russlan. Early and prolific; fruits are small, oval, pointed, crisp and good. Oz. Io cts., 1/4lb. $30 \mathrm{cts}$., 1b. \$I.

Japanese Climbing. Vigorous, tall-climbing, and clings tightly to trellises. Fruits almost straight, large, and from I2 to I6 inches long; skin dark green; flesh thick and delicately flavored. Oz. Io cts., $x / 41 \mathrm{~b} .30 \mathrm{cts}, 1 \mathrm{~b} . \$ \mathrm{I}$

West India GherkIn. Its small, rough, prickly fruits are used for pickling. The vines grow quite rapidly and bear heavily. $\mathrm{Oz}$ 20 cts.

English Frame, Best Varieties. Sion House, Telegraph. $25 \mathrm{cts}$. each per packet.

\section{ENDIVE (The Winter Salad) (Endivie)}

This is an important fall and winter salad. For early the seed should be sown in April, in drills $I_{5}$ inches apart, and the seedlings thinned to stand 12 inches apart in the rows. Sowing for the main crop can be made in June and July, as the vegetable is used principally in fall and winter. The inner leaves may be blanched to a beautiful yellowish white in from 3 to 5 weeks, by tying the tips of the outer ones together, or by laying boards over the plants. Ordinarily good soil and culture are all the crop requires. An ounce of seed will sow roo feet of drill.

Green Curled. The one most generally cultivated. Dark green leaves, beautifully curled, and when blanched very crisp and tender; they are ready for use a little earlier than the other sorts. Oz. $20 \mathrm{cts}$., $1 / 1 \mathrm{lb}$. 50 cts., 1b. $\$$ I.50.

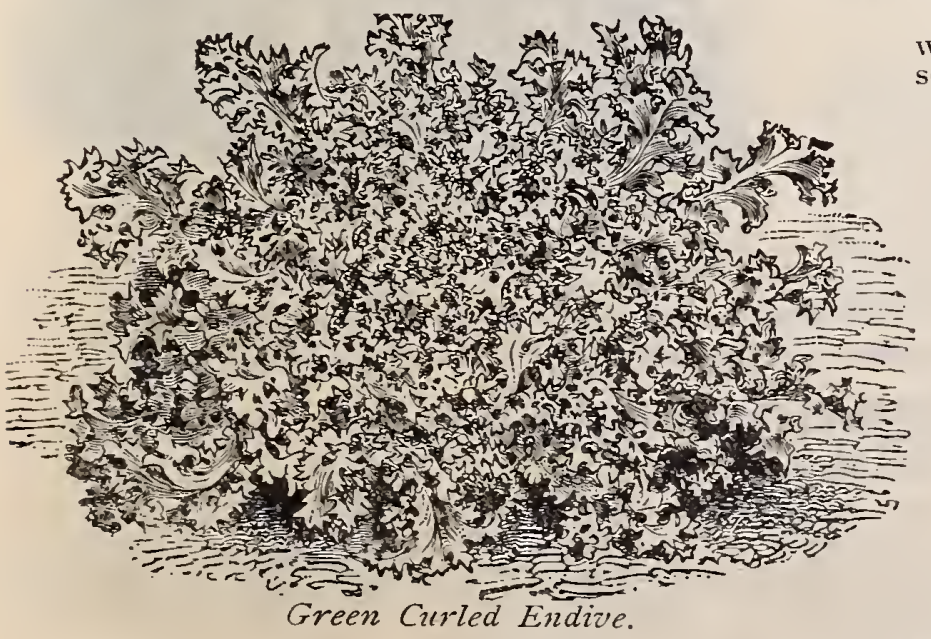

Broad-Leaved Batavian. The broad, thick leaves make excellent salads when blanched. The plant is very hardy, and yields heavier crops than other sorts, but does not blanch so easily. Oz. $20 \mathrm{cts}$., 1//1b. $50 \mathrm{cts}$., 1b. \$1.50

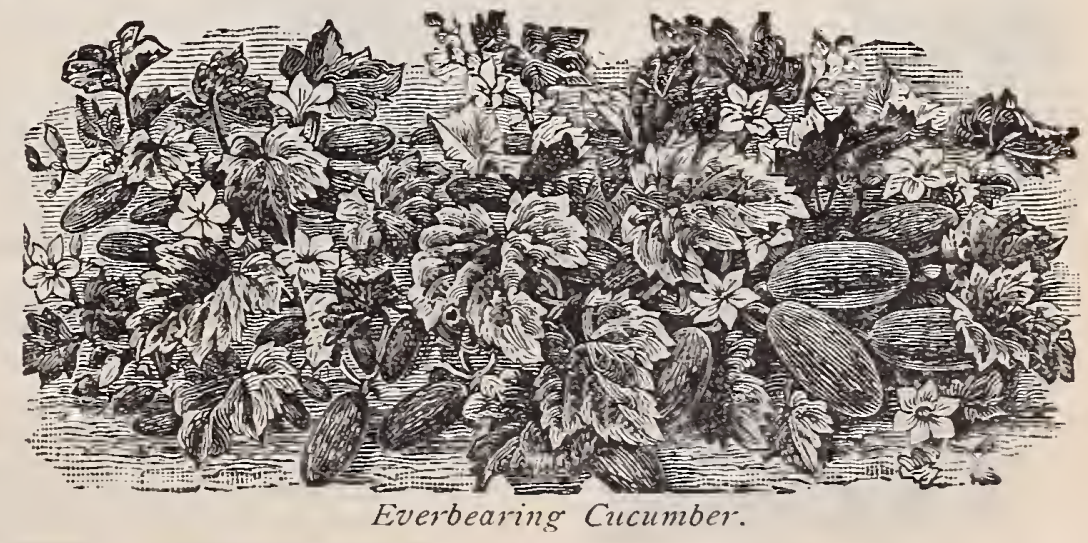

ALL VEgETABLE SEEDS SOLD AT THE UNIFORM PRICE OF 5 CENTS PER PACKET 

September. Oz. I5 cts., I/41b. 35 cts., 1b. $\$$ I.

\section{KALE, or BORECOLE}

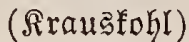

Under this name are classed several species of the cabbage family which do not form heads. Some of them have very tender leaves of delicate flavor, and all are quite hardy, and improved rather than injured by frost. Sow the seed in beds in April or May, and transplant and cultivate the seedlings like cabbage. They will grow in almost any soil, but both the flavor of the leaves and the yield is greatly improved by a rich one. An ounce of seed will sow about 200 feet of drill.

Dwarf German Greens (Siberian Kale). A standby everywhere for winter greens. The seed is generally sown broadcast, but can be sown in drills a foot apart in September, and the plants treated like spinach; they will be ready for use early in

Dwarf Curled Green Scotch. A dwarf-spreading variety, seldom exceeding I 8 inches in height, but rounding out to a diameter of 3 feet under good cultivation. The leaves are bright green, tender and elegantly curled. The variety is very hardy and one of the best grown. Two weeks later than the preceding sort, but stands longer before going to seed. Oz. I5 cts., 1/4 1b. 35 cts., 1b. \$I.

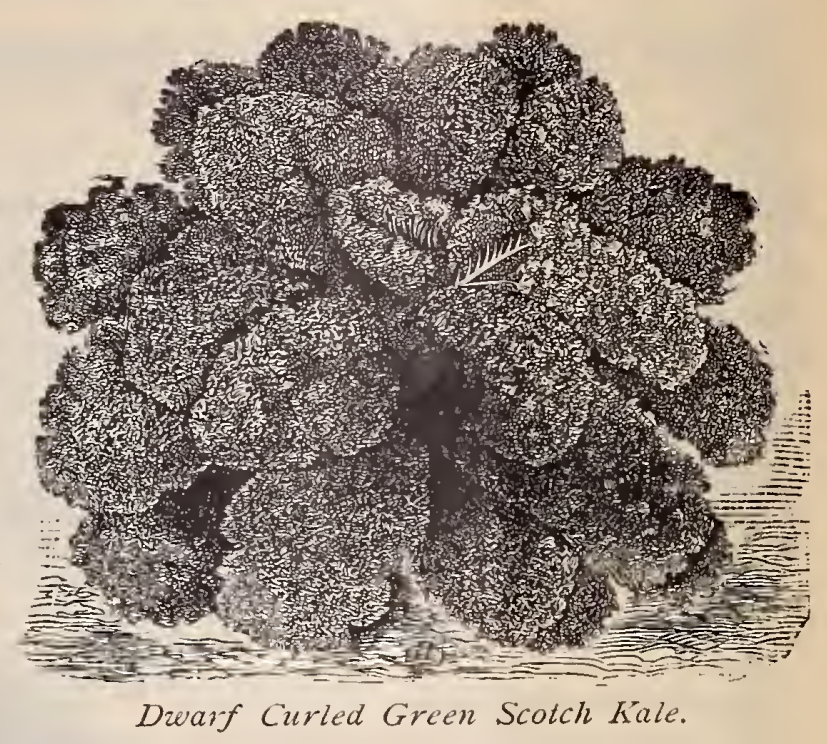

KOHLRABI

$(\Re \mathfrak{o b l}$ rabi)

This Turnip-Rooted Cabbage is grown extensively in Europe for stock-feeding, and is steadily gaining favor in this country. The roots are very palatable when prepared for the table like turnips, and when fed to cows give no unpleasant flavor to the milk. If the weather is favorable, the seed should be sown in April, in rows in inches apart, and the seedlings thinned to stand a foot apart for large varieties, and 6 or 8 inches apart for other sorts; they are somewhat difficult to transplant. The stems swell into large bulbs just above the ground, and these are fit for use when 3 or 4 inches in diameter. For late crops, sow seed in June or July. An ounce of seed will produce about 3,000 plants.

Early White Vienna. The best and earliest market sort. The plants grow rapidly, have small foliage and mature their fine, round, white bulbs quite early; the flesh is fine-grained, white, tender and good. The tops are quite short. $\mathrm{Oz} .20 \mathrm{c}$., $1 / 1 \mathrm{lb}, 65 \mathrm{c} ., 1 \mathrm{~b} . \$ 2$.

Early Purple Vienna. This variety differs from the above mainly in the color of its roots, which are bluish purple; in quality they are superior to those of many other sorts. Oz. 20 cts., $1 / 41 \mathrm{~b} .65$ cts., $1 \mathrm{~b} . \$ 2$.

\section{LEEKS OF THE BEST SORTS ( (auch)}

The Leek is generally considered superior to the onion in flavor, and is much used for seasoning soups and boiling with meats. The plants are easily cultivated and very hardy, enduring the severest winter weather without protection. The seed should be sown in hotbeds in early spring, and the seedlings transplanted later to the open ground, 8 inches apart, in rows from I 2 to $\mathrm{I} 5$ inches apart. For a winter supply of this, sow seed in the open ground in early spring, and thin the seedlings until they have room for development, or transplant them as above; the former method gives larger stalks some time earlier than London Flag Leek.

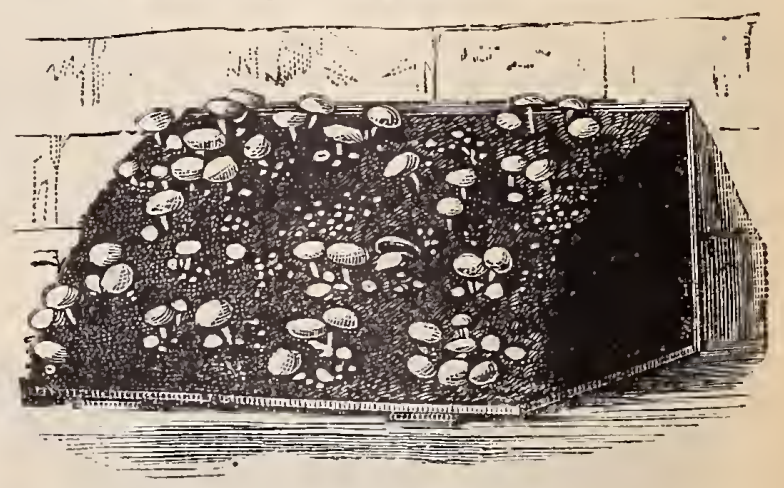

Mushroom Spazon. when the roots are transplanted. They should be stored like celery for winter. An ounce of seed will sow about roo feet of drill.

Musselburg. A hardy, popular sort, with broad, spreading leaves and very large stalks. Pkt. 5 cts., oz. 30 cts., $1 / 41 \mathrm{~b}$. $\$ \mathrm{I}, 1 \mathrm{~b} . \$ 3.50$

London F1ag. The variety most extensively cultivated. The stalks are large, and the leaves grow from their sides, as in the Flag. Oz. 20c., 1/41b. 6oc., 1b. \$r.75.

\section{DANDELION (\&̈̈menzagn)}

Furnishes our earliest and most healthful crop of spring greens. Sow the seed as

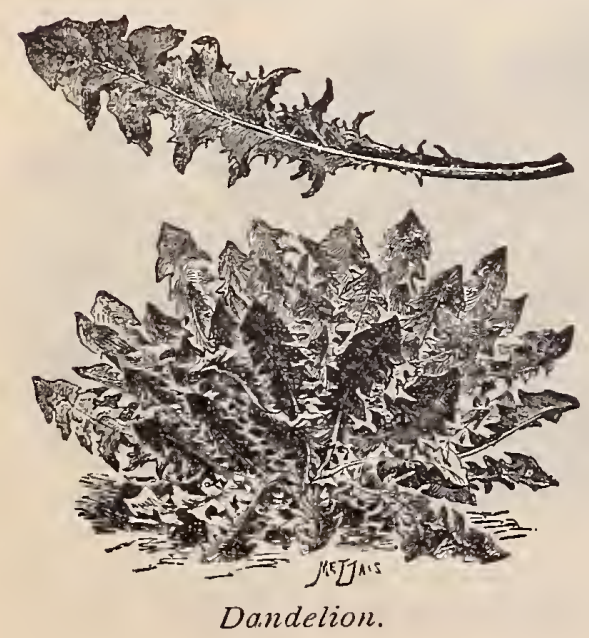
early as the weather will allow, in good, well-enriched soil, and in rows a foot apart; cover them only one-fourth of an inch deep, and firm the soil down above them. The plants should be thinned to stand 2 or 3 inches apart in the rows, that the roots may grow large and solid, thus saving much time in trimming them. An ounce of seed will sow roo feet of drill; a pound will sow an acre.

Improved American, Thick-Leaved. The best variety. "Oz. $40 \mathrm{cts}$., T/41b. $\$ 1.25,1 \mathrm{~b} . \$ 4$.

\section{MUSHROOM SPAWN}

(Ehampignonbrut)

Provide a sufficient quantity of fresh stable manure, and throw into a heap to heat. Turn and mix several times, till the heat is evenly distributed, and then make the bed under cover, similar to a hotbed. When the heat is found to be gentle, prepare the spawn by breaking into pieces about 2 inches square, and place them 6 inches apart each way; spread over them I inch of good loam. Cover with straw, and if the loam becomes dry, water with tepid water.

Fine English, "Milltrack." Lb. I5 cts., 8 lbs. \$i.

Best Quallty, Home-Made. Lb. I5 cts., 8 lbs. \$I. (Special price in quantity.) 


\section{Lettuce}

(Barten Salat)

Lettuce is a plant of most simple culture when grown in the open air. It requires rich soil, plenty of well-rotted manure and abundant moisture. With these conditions, its growth is vigorous and rapid; and to be crisp and tender it should be grown quickly. Of all the salad plants, Lettuce easily takes the lead; and no garden is worthy the name without its Lettuce beds. It has few, if any, insect enemies, and flourishes throughout the spring and summer months. Drought and hot weather are its worst enemies, as during such periods it inclines to run up to seed. Seed may be sown in a frame in February or March, not much bottom heat being required. The plants may be set out as early as the ground can be worked, as light frosts will not injure them. Set in rows about I 8 inches apart, leaving 8 or Io inches space between the plants. For successive crops, sow every two weeks up to July. One ounce will produce 3,00o plants.

Boston Market (White-seeded Tennisball). Grown éxtensively by market gardeners, under glass, for winter use ; very compact head and of the best quality. Oz. I5 cts., $\mathrm{T} / \mathrm{lb}$ lb. $50 \mathrm{cts}$., lb. $\$ 1.50$.

Tomhannock. Leaves almost white, crisp and tender; edges of the outer leaves reddish bronze; very handsome. Oz. $\mathrm{I}_{5} \mathrm{cts}, 1 / \mathrm{lb}$. $50 \mathrm{cts}, \mathrm{lb} . \$ 1.50$.

Sensation. A valuable outdoor Lettuce. Of large size, solid, good color: stands well during the lot summer months. Oz. I5 cts., $1 / 4 \mathrm{lb} .50 \mathrm{cts} ., 1 \mathrm{~b} . \$ 1.50$.

Denver Market. Leaves wrinkled like savoy cabbage. Large heads, light green color; flavor fine and delicate; quite early. A well-known and very popular Lettuce. Oz. I5 cts., I/41b. 50 cts., 1b. \$1.50.

Black-seeded Simpson. A popular variety, excellent both for forcing and open ground crop. Grows very rapidly, withstanding heat and drought unusually well, and forming large, bushy, light-colored stalks. Oz. I5 cts., 1/41b. 50 cts , 1b. $\$$ r.5O.

White-seeded Simpson. For sowing broadcast early in spring for gathering Lettuce. Leaves delicate light green, very curly and well flavored. Oz. I $5 \mathrm{cts}, 1 / 4 \mathrm{lb}$. 50 cts., lb. \$1 . 50 .

Black-seeded Tennisball. This variety is the most popular for open-air culture it forms a handsome, compact head, with very few outside leaves, and is crisp and tender. Oz. I 5 cts., $1 / 41 \mathrm{lb}$. $50 \mathrm{cts}, 1 \mathrm{~b}$. $\$ 1.50$.

Big Boston. Similar to Boston Market, with heads twice as large, and a week later in maturing for use. The solidity and large size of the heads make them of great value for general crop. Oz. I5 cts., 1/4lb. 50 cts., $1 \mathrm{~b}$. $\$ 1.50$.

All-the-Year Round. May be grown at any season of the year. Heads of medium size, firm, close, crisp and very good. Oz. 15 cts., 1/41b. 50 cts., $1 \mathrm{~b}$. \$ 1.50 .

Manson. Large and vigorous, and forms immense heads; leaves green, light yellow within; sweet, crisp. One of the best. Oz. I5 cts, $1 / 1 / 1 \mathrm{~b} .50 \mathrm{cts}$, $1 \mathrm{~b} . \$ 1.50$

Curled Silesia. Very early and tender; a favorite in the family garden. $\mathrm{Oz}$ I5 cts., I/4lb. $50 \mathrm{cts}$., 1b. $\$ 1.50$.

White Paris Cos. A sort with long, narrow, upright leaves; does not head, but when tied up blanches very nicely; bears close planting. $\mathrm{O} z$. I $5 \mathrm{cts}, \mathrm{I} / \mathrm{lb}$. $50 \mathrm{cts}$. 1b. $\$$ I.5O.

\section{MARTYNIA}

\section{(Bemientiorn)}

The seed-pods are excellent for pickling if gathered when tender and about half grown. Sow the seed in May in rows 3 feet apart, and thin the plants to stand 2 feet apart in the rows.

Proboscidea. The best variety. Oz. $30 \mathrm{cts}, \mathrm{I} / \mathrm{lb} . \$ 1,1 \mathrm{~b} . \$ 3$.

\section{MUSTARD}

(ङenf)

The young and tender leaves of the Mustard are greatly relished as salads, or when cooked like spinach. The seed should be sown in shallow

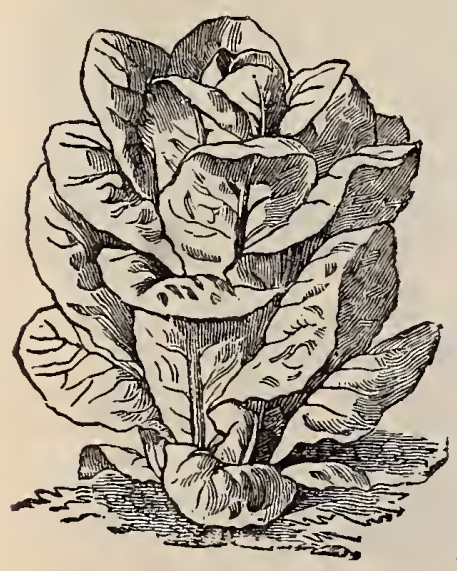

White Paris Cos Lettuce. drills as early as the oround can ke pre. pared in spring, and the leaves cut when several inches long. Oz. Io cts., $1 / 41 \mathrm{~b}$. I5 cts., lb. 30 cts.

\section{NASTURTIUM}

\section{Indianisabe}

The seeds while young and tender are pickled and used as capers. The plants are highly ornamental; the tall varieties make an excellent screen for unsightly places in the garden or along fences anywhere.

Tall Mixed Colors. Oz. Io cts., $1 / 4 \mathrm{lb}$. 30 cts., lb. $\$$ I.

Dwarf Mixed Colors. Oz. Io cts., $1 / 4 \mathrm{lb}$ 30 cts., 1b. $\$$ I.

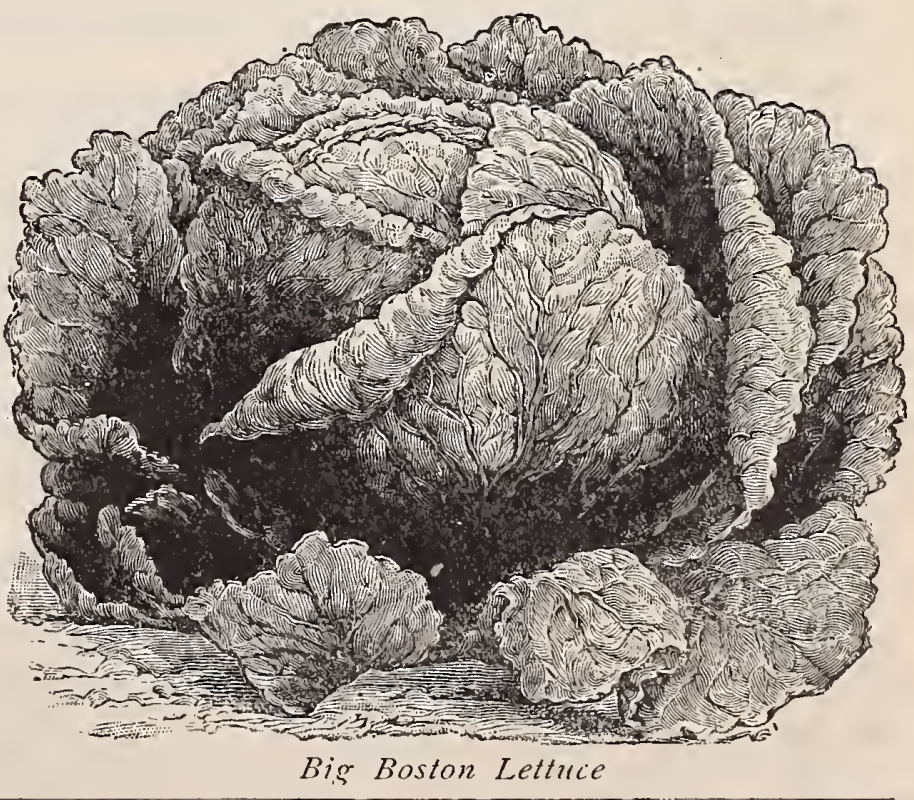

Our Lettuce is all New England=grown from Selected Stocks. 


\section{Muskmelons}

IIuskmelon seed should not be planted outdoors until all danger of frost is orer and the ground has become warm and dry. The hills should be about 6 feet apart, and carefully prepared. Rich earth is far better for the young plants than manure, but if the latter must ne used, see that it is well rotted. Plant from six to twelve seeds in a hill, and when the young seedlings are strong enongh to

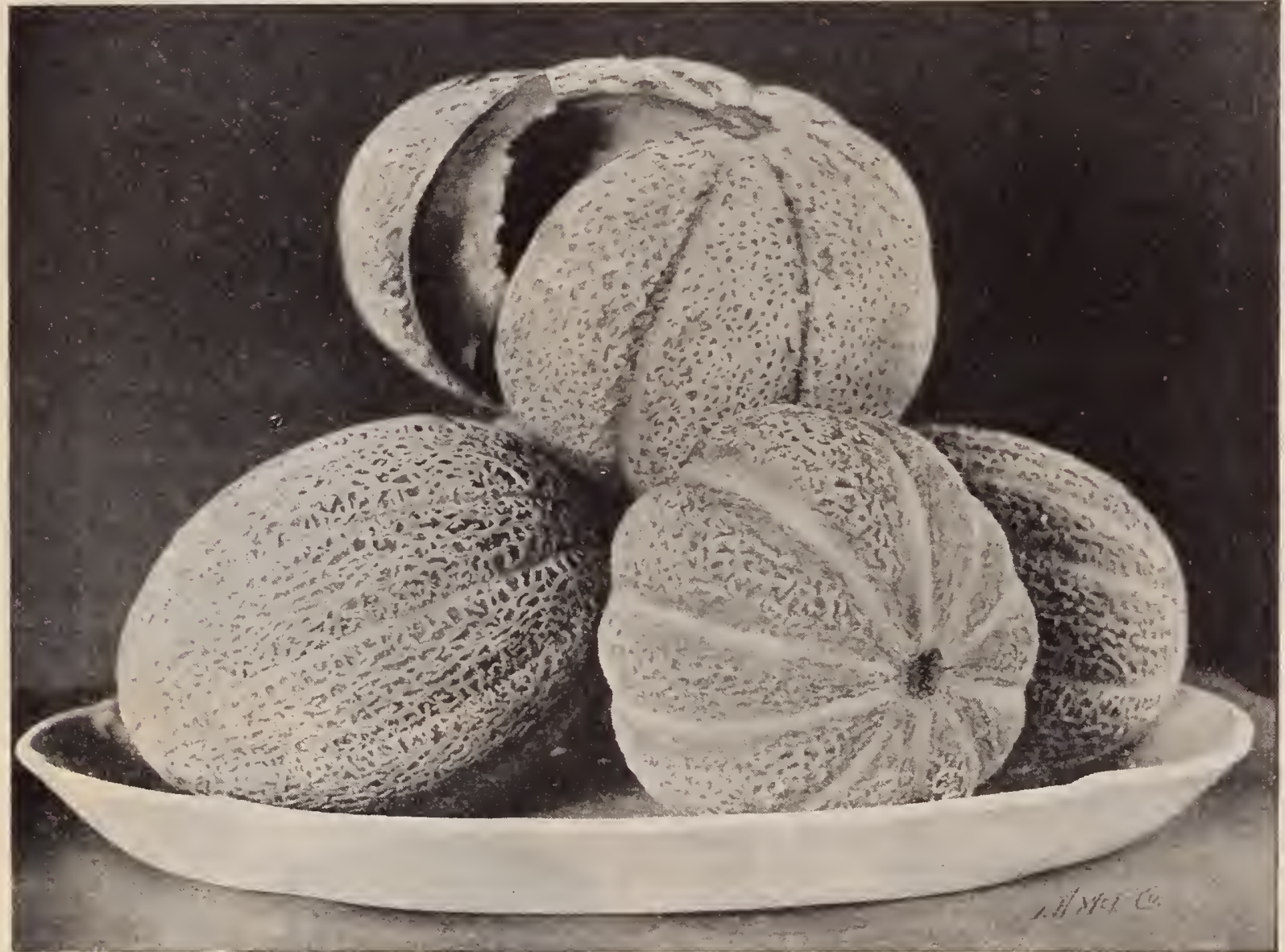

Extra-Early Hackensack and Rocky Ford. resist the atiacks of insects, thin them, leaving three of the strongest in each hill. The vines should have clean cultivation until they corer the ground, and if they grow too rank, the tips of the shoots should be pinched off, causing them to set more fruits and develop them to finersize. An ounce of seed will plan. about So hills.

Extra-Early Mackensack. A selection from the Hackensack, and witls fruits much like the parent, but ready for market ten days earlier. Of good size, weighing from 5 to Io pounds each. Oz. Io cts., $1 / 41$ lb. 30 cts., lb. $\$ 1$.

Emerald Gem. Early, with small. smooth-ribbed, dark green fruits; flesh thick and salmon-colored, granular. sweet and rich; very delicions and satisfying to the taste; the vines bear heavily. Oz. I5 1//1b. 40 cts , lb. $\$ 1.25$

Princess, or Perfec. tion. Notably fine, witl fruits having flesh so thick and seed cavity so small that they seem almost solid. Rind thin tough and sparingly netted: flesh rich salmon, fine-grained, sugary and melting; vines strong and productive; one of the best, and also one of the most popular Muskmelons known to market-gardeners. Oz. Io cts., 1/4lb. $3 n$ cts., lb. $\$ \mathrm{I}$.

Miller's Cream, or Osage. Fine, attractive fruits, which sell quickly in market, and, therefore, a favorite among the truckers. The fruits are large and round, with light green, netted skin and thick, sweet, salmon-colored flesh. Oz. 1o cts, 1/4 lb. $30 \mathrm{cts}$, $1 \mathrm{~b}$. $\$ 1$.

White Japan. One of the sinallest varieties, of a pale, greenish white color. It is both early and prolific, and its flavor and sweetness are unsurpassed. Oz. Io cts., 1/4 lb. $30 \mathrm{cts}$., lb. $\$ 1$.

Arlington Nutmeg. A popular variety, extensively grown by market vegetable growers; good flavor; flesh yellowish green. Oz. Io cts., $1 / 4 \mathrm{lb}$. 30 cts., 11. \$I.

Livingston's Tiptop. A new and very distinct variety, first discovered in a large field in Lancaster county, Pa. In quality it is one of the best of the yellow-fleshed sorts Of good size, and its appearance is very captivating. Oz. Io cts, I/4lb. $30 \mathrm{cts}, 1 \mathrm{~b}$. $\$ 1$.

Long Island Beauty. Round; one of the earliest and finest. Oz. Io cts., 1/41b. $30 \mathrm{cts}$. 1b. \$I.

8urprise. One of the finest. The melons ripen early and have a thin, cream colored rind, and thick, sweet, salmon-colored flesh. Oz. Io cts., $1 / 4 \mathrm{lb}$. $30 \mathrm{cts}$, , lb. $\$ \mathrm{I}$.

Paul Rose. Medium size, rather elliptical in shape, netted, salmon-fleshed, and so thick-meated as to be almost sclid; quality firstclass. It is a cross between the netted Gem and the Osage, or Miller's Cream. Oz. Io cts., 1/41b. $30 \mathrm{cts}$., 1b. \$I.

Rocky Ford. This new and valuable introduction has attained a great reputation in a very short time. It is oval in shape, of a delicate flavor; flesh light green; size medium. A good shipper. Our engraving from a photograph perfectly represents it. This is the melon which has made so much money for Colorado shippers. Oz. Io cts, 1/41b. $30 \mathrm{cts}$., $1 \mathrm{~b}$. \$1.

\section{Watermelons (2aieirtermelonent)}

An effort should be made to secure good, strong vines early in the season, and this can be done by taking care that the hills are large, mellow and well drained, with the manure placed so that they will not dry out quickly under hot suns. All possible protection from insects should be given the young plants, and their growth may be hastened still further by frequent applications of liquid manure. As a protection from insects, netting is frequently used, and also dry ashes or coal-dust sprinkled over the leaves when wet. Plant the seeds thickly, and thin the plants to four of the strongest in each hill. An ounce of seed will plant about 60 hills.

Cole's Early. A fine early Watermelon; can be grown over fleshed, with light-colored seeds; quite hardy and very productive; a large latitude; flesh bright red, delicate in texture; fruit nearly round ; rind thin. Oz. Io cts., 1/4 1b. $25 \mathrm{cts}, 1 \mathrm{l}) .75 \mathrm{cts}$.

Sweetheart. Large and nearly globular; skin bright, mottled green ; flesh bright red, firm and heary, crisp, melting and exceedingly sweet. A good shipper and keeper. Oz, IOc., 1/4lb 25c, 1b. 75 :

Kolb Gem. Unusually prolific; fruits very large, roundish oval, with rind as hard and tough as in a winter squash, and striped with light and dark green. Oz. Io cts., I//1b. 25 cts., 1b. 75 cts.

Phinney's Early. A very early variety, of medium size; redquality excellent. Oz. Io cts., $1 / 41 \mathrm{lb} .25 \mathrm{cts}$., $1 \mathrm{~b} .75 \mathrm{cts}$

Cuban Queen. One of the very best new varieties, of round shape and of large size; flesh bright red, very crisp, delicate and sweet; an early and reliab!e sort. Oz. IOc., $1 / 4 \mathrm{lb} .25 \mathrm{c}$., $1 \mathrm{~b} .75 \mathrm{c}$.

Mountain Sweet. An old favorite; form rather long ; color dark green; seeds dark; a very solid melon, sweet and crisp; a safe variety for northern growing. Oz. Io cts., I/4 1b. $25 \mathrm{cts}$., 1b. $75 \mathrm{cts}$.

Red-Seeded Citron. Round, marbled with light green. Flesh white and solid, seeds red. Oz. I0 cts, 1/4 1b. $25 \mathrm{cts}$., $1 \mathrm{~b} .75 \mathrm{cts}$. 


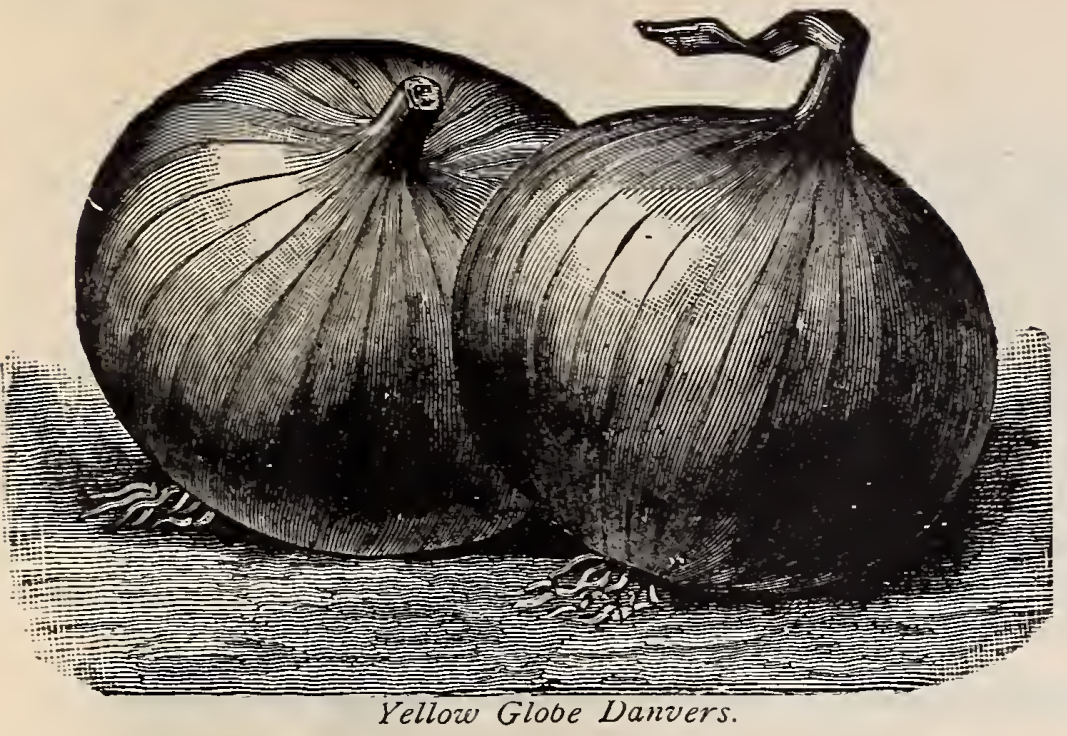

\section{Onion Seed}

(3wiebel)

All New England-grown

The Onion has been cultivated as an article of food from the earliest times, and is now perhaps more universally grown than any other vegetable. A good crop is impossible unless the soil is very rich and kept clean. Use well-rotted manure freely, and get the crop in as soon as possible in the spring, no matter if the weather is cold and unpleasant. Sow in drills I foot apart, and cover about one-third of an inch, treading or rolling after sowing, so that the hot dry atmosphere may not dry up and destroy the sprouting seed. When 3 inches high, thin to 2 inches apart. Stir the ground freely without

GOOD ONION SEED is the foundation for a Good Crop of Onions disturbing the young plants and keep

free from weeds. One ounce to Ioo feet of drill ; 4 to 5 pounds per acre.

Yellow Globe Danvers. Buxton type, selected, home-grown stock. Globe-shaped; early, with very small neck; large size; fine quality and good keeper: the best for general crop. Oz. I 5 cts., $1 / 1$ lb. 50 cts., 1b. \$I.5o.

Red Wethersfield. One of the most productive and long-keeping. Bulbs deep purplish red, large, flat, strong flavored, and grow to a large size the first year from seed. Oz. I5 cts., I/4lb. 50 cts., 1 b. $\$$ I.50.

Extra-Early Red Globe. Of the famous Southport type, as handsome and much earlier, maturing with Early Flat Red and Danvers. Oz. I5 cts., 1/41b. 50 cts., 1b. \$1.50.

Southport White Globe. A large, showy, globular white Onion, which sells quickly in market. The bulbs grow quite rapidly, and if the seed is sown early, good-sized roots, suitable for pulling and marketing in a green state, are soon formed. They are mild flavored, keep well and the yield is good. Oz. $20 \mathrm{cts}$., $1 / 1 \mathrm{l}$ b. $60 \mathrm{cts}$., $1 \mathrm{~b}$. $\$ 2$.

White Portugal, or Silverskin. Largely grown for white Onion sets. Bulbs large and fine in appearance, with silvery white skin, and sweet, tender white flesh; they do not keep well, but are niild flavored, and excellent for family use and for pickling. $\mathrm{Oz}$. 20 cts., $1 / 1 \mathrm{lb} .60 \mathrm{cts}$., $1 \mathrm{~b} . \$ 2$.

Spanish King, or Prizetaker. Bulbs very large, round and handsome; rich yellow skin, and mild, sweet, pure white flesh; quite free from stiff necks; bottom well; and yield enormously. A very desirable sort. Gz. I5 cts., 1/41b. 50 cts., 1b. \$1.75.

\section{ONION SETS}

These are small Onions grown the previous year, ripened off and taken up when mere bulblets. They produce a very early and profitable crop, and grow in any good soil. Set them in rows I foot apart and 3 inches apart in the rows.

White Sets, Yellow Sets, White Multiplier Sets, Potato Onion Sets, Shallots, Top Onion Sets. Market price; price variable.

\section{OKRA (こajran)}

The tender young pods are used for seasoning soups and stews. Sow the seed thickly, in rich soil, about the middle of May, in drills 3 feet apart, and cover the seeds

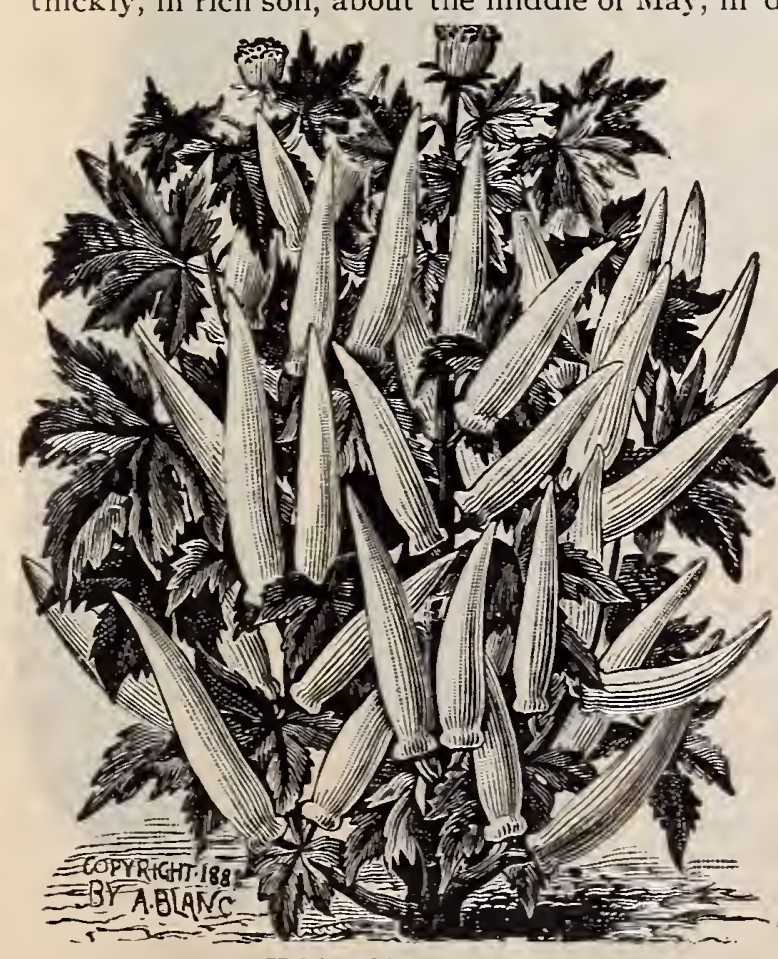

White Velvet Okra. an inch deep. Thin the young plants to stand Io inches apart, hoe them

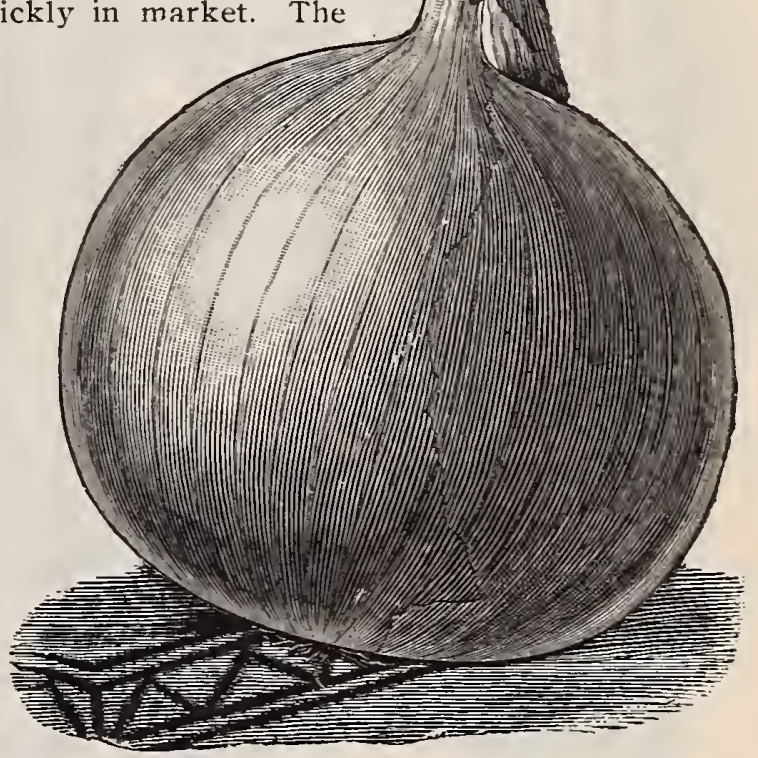

Spanish King, or Prizetaker.

often, and earth up the stems a little in cultivation, for support. An ounce of seed will plant Ioo hills.

Improved Dwarf. Growing about I4 inches high, and producing twice as many pods as the taller sorts. The pods are smooth, tender and well-flavored. Oz. Io cts., $1 / 4 \mathrm{lb}$. 35 cts., lb. \$I.

White Velvet. Pods pure white, round and smooth, with no square edges or disagreeable prickles; also larger than in most sorts ; produced abundantly. Oz. Io cts., I/4lb. 35 cts., lb. \$I.

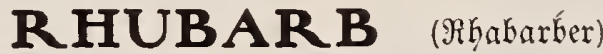

This plant is mostly propagated by division of the roots. The best time to set out the plants is early in the spring, although it is sometimes done in autumn. Nake furrows of good depth, 3 or 4 feet apart, according to the variety planted; across these furrows at right angles, make others the same distance apart; at each intersection put 3 or 4 shovelfuls of good manure, and upon this set the plants. Any good soil will suit Rhubarb but to obtain heavy crops, good soil, well manured is indispensable.

Linnæus. The earliest and best for garden use; not as coarse and fibrous as the larger sorts. Oz. 25 cts., 1/4lb. 65 cts., lb. \$2.

Victoria. The variety in general use for the market; vields immense crops. $\mathrm{Oz}$ 25 cts., $1 / 41$ lb. 65 cts., 1b. $\$ 2$. Roots of the above varieties, per doz. $\$ 1.50$; per $100, \$ 7$.

\section{PARSLEY (Feterifici)}

The leaves of most sorts of Parsley are beautifully curled, and useful for garnishing as well as flavoring. An ounce of seed will sow about $\mathrm{I} 5 \mathrm{O}$ feet of drill.

Dwarf Extra Curled. Dwarf, with finely curled leaves. Oz. Io cts., $1 / 1 \mathrm{lb}$. 25 cts., 1b. 75 cts.

Champion Moss Curled. Leaves bright green, finely cut and beautifully curled. Oz. Io cts., 1/16. 25 cts., lb. 75 cts. 


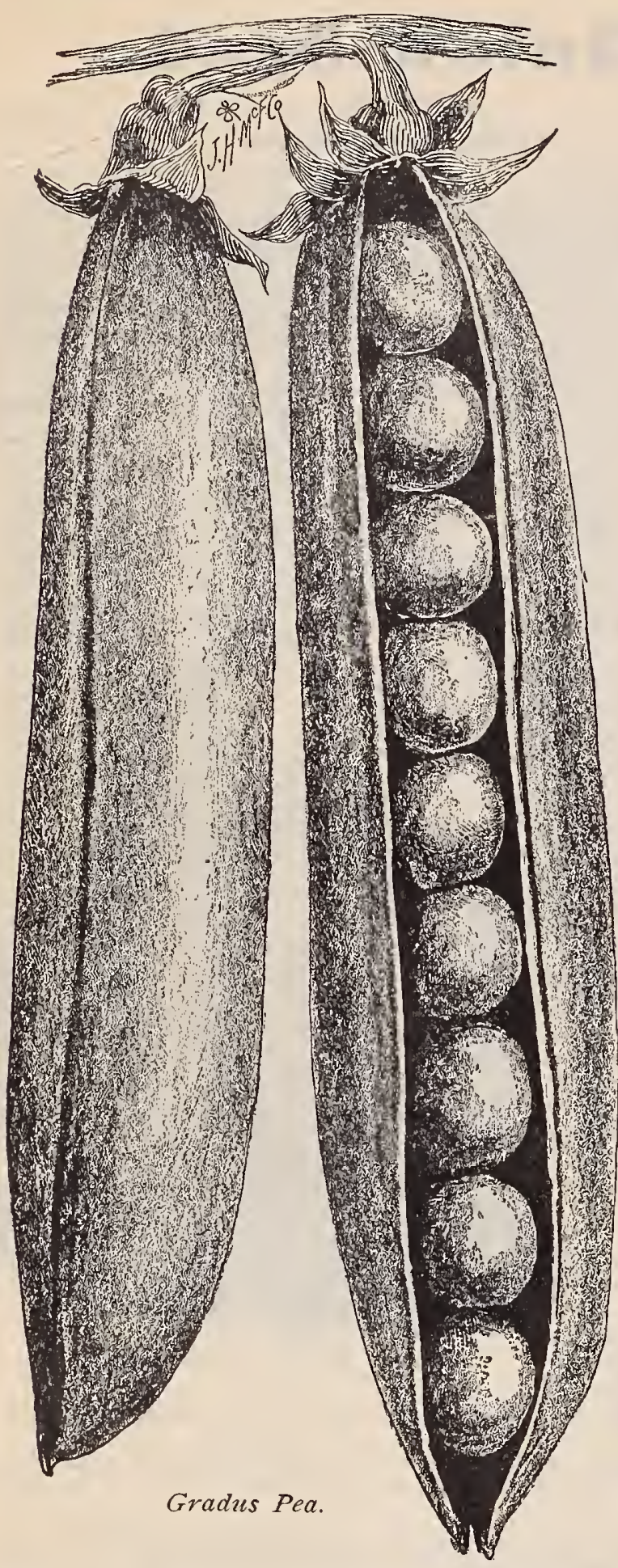

\section{Peas (Erbirin)}

All smooth-seeded Peas may be planted as early in spring as the soil can be prepared for them. They are very hardy, and will endure a low temperature, both before and after sprouting. By sowing for the first crop as early as is practicable and for succession at intervals of about two weeks until the first of June, a good supply of this delicious vegetable may be enjoyed through the greater part of the summer. Late sowings, however, do not yield as well as early ones, because the hot and dry weather is unfavorable to the development of the plants. The seeds should be sown in drills about 3 inches deep and from 3 to 4 feet apart, according to the variety, taller sorts requiring more room than dwarf ones. Dwarf Peas require a very rich soil, while tall ones thrive best in rather thin ground, which does not stimulate too luxuriant growth in the vines, to the detriment of the pods. The latter are frequently sown in double rows, with brush or support of some kind between them. Wrinkled Peas are not so hardy as the smooth sorts, and should not be sown as early, but are superior to them in quality, more delicate in flavor, and remain longer in season. One quart of seed will plant about I 25 feet of drill.

DF For Peas to be sent by mail, add postage at the rato of 15 cts. per quart to prices given.

\section{EXTRA=EARLY PEAS, Medium and Dwarf Sorts} $A(*)$ indicates a wrinkled variety

The W. E. H. Co.'s Maud S. A favorite with the market-gardeners on account of its earliness and extreme productiveness, its vigor and vitality, often resisting a drought, and maturing a crop when ordinary sorts of earlies have failed. 2 feet. Qt. 25 cts., $1 / 2 \mathrm{pk} .75 \mathrm{cts}$., bus. $\$ 4.50$.

Early Dexter. Worthy of a trial by market-gardeners. Selected as being very early. Qt. 25 cts., $1 / 2$ pk. 65 cts., bus. $\$ 4$.

Improved Dan O'Rourke. An old standard early ; very productive and popular. $21 / 2$ feet. Qt. 25 cts., $1 / 2$ pk. 65 cts., bus. $\$ 3.75$.

Alaska. One of the earliest in cultivation; about 75 per cent of the pods can be gathered at the first picking. Vines 2 feet high; pods small, but well filled with plump, excellent dark green peas. Qt. $25 \mathrm{cts}$., $1 / 2 \mathrm{pk} .65 \mathrm{cts}$., bus. $\$ 3.75$.

First and Best. Similar to Maud S. Early, prolific and uniform in ripening. Qt. 25 cts., $1 / 2$ pk. 65 cts., pk. $\$ 4$.

Gradus. (New.) This is undoubtedly the greatest advance ever achieved in Peas, for it is as early as the first earlies, with pods as large as the Duke of Albany and the same shape and color, each pod containing nine or ten wrinkled peas of true marrow flavor; altogether the most distinct and largest podded early Pea ever raised. Stock this season limited. Qt. $40 \mathrm{cts}$., $1 / 2 \mathrm{pk}$. $\$ 1.25$, bus. $\$ 9$.

"Nott's Excelsior. The finest dwarf $\mathrm{Pea}$ in cultivation; robust and vigorous in growth; throws out laterals from the base of the stock, producing in profusion long, handsome pods, closely packed witl large peas of fine flavor; more vigorous and prolific, with larger pods and more peas than either American Wonder or Premium Gem sure to be very popular when generally known. seed green and wrinkled. 12 inches. Qt. $30 \mathrm{cts}, \mathrm{t} / 2 \mathrm{pk}$. $\$$ I, bus. $\$ 6.50$.

American Wonder. One of the earliest of wrinkled Peas: flavor and quality excellent, vines dwarf and strong. 10 to 12 inches high; pods long and well filled; a favorite. Qt. 3 oc , $1 / 2 \mathrm{pk} . \$ 1$, bus. $\$ 6.50$

Mclean Premlum Gem. Very early and superior dwarf wrinkled Peas, with vines well branched, and from I2 to 15 inches high pods ve y abundant. Peas tender, sweet and good. Qt. $30 \mathrm{cts}$., 1/2 pk. $\$ 1$, bus. $\$ 6$.

Allan's Dwarf Telephone. This Pea will fill a long-felt want. Large, handsome pods, with peas of highest quality, without the long vines of the Telephone. Season medium. 18 inches. Qt. 40 cts., $1 / 2$ pk. $\$$ r.25, bus. $\$ 7.50$

New Dwarf Champlon. Messrs Rogers Bros., who introduced this new variety, speak very highly of it. Qt. 25 cts., $1 / 2 \mathrm{pk}$. $75 \mathrm{cts}$., bus $\$ 4.50$.

\section{INTERMEDIATE and LATE SORTS}

*McLean's Advancer. Second early. Qt. 25 cts., $1 / 2$ pk. 75 cts, bus. $\$ 4.50$. Pride of the Market. A productive main-crop variety. Qt. 30 cts., $1 / 2 \mathrm{pk}$. $\$ 1$, bus. $\$ 6$.

* Telephone. Pods and peas very large and showv, the latter being very sweet and rich very popular. Vines $3^{1 / 2}$ feet high. Ot. $30 \mathrm{cts}$, $1 / 2 \mathrm{pk} .85 \mathrm{cts}$, , bus. $\$ 5$.

: Stratagem. Late English variety; large, showy pods. Qt. $30 \mathrm{cts}$., $1 / 2 \mathrm{pk}$. $\$ 1$, bus. $\$ 6$

Shropshîre Mero. Medium early; heavy cropper. Qt. $25 \mathrm{c}$., $1 / 2 \mathrm{pk}$. $75 \mathrm{c}$., bus. $\$ 4.50$.

Bliss' Everbearing. Large, well-filled pods. Qt. 25 cts., $1 / 2$ pl. 75 cts., bus. $\$ 4.50$.

* Bliss' Abundance. A wrinkled, medium early Pea. Ot. $25 \mathrm{cts}, 1 / 2 \mathrm{pk} .75 \mathrm{cts}$., bus. $\$ 4.50$.

Champion of England. A tall-growing, green, wrinkled marrow. Qt. $25 \mathrm{c}$., 1/2 pk. 65c., bus. $\$ 4$

Dwarf Whlte Marrow. A good late sort. Qt. $15 \mathrm{cts}, \mathrm{I} / 2 \mathrm{pk}$. $40 \mathrm{cts}$, bus. $\$ 2.50$.

Black-Eyed Marrow. For late crop. Qt. 15 cts., $1 / 2$ pk. 40 cts., bus. $\$ 250$.

Mammoth Melting Sugar. Best edible-podded peas. Qt. $35 \mathrm{cts}$., 1/2 pk. \$1.25.

Canada Field. Used for fodder. Sown with oats. Bus. $\$ 2$.

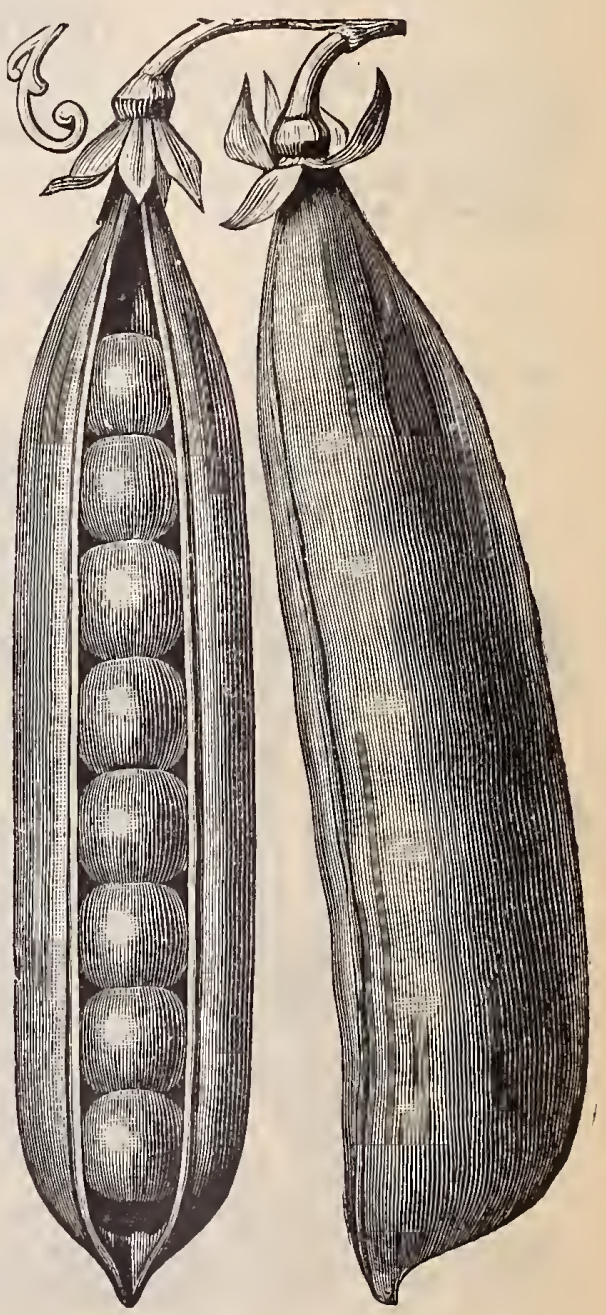

Nott's Excelsior Pea. 


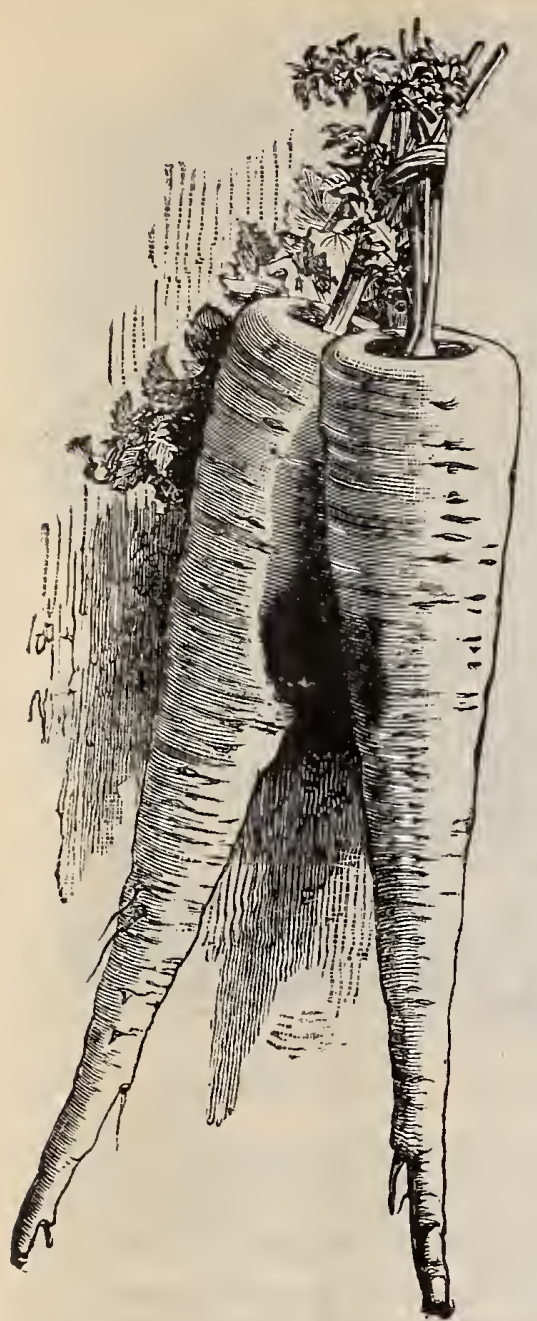

Improved Hollow Crown Parsnip.

\section{PARSNIPS}

( $\mathfrak{R a s ̧ t i n a f e ) ~}$

Aside from its value as a table vegetable, the Parsnip also furnishes a healthful and nourishing food for stock, and is especially valued for this purpose by dairymen. Sow the seed in drills 15 inches apart, as early as possible in spring, and thin the plants until they are 5 or 6 incles apart in the rows The roots are improved by frost, and only enough for winter use need be taken up in the fall, leaving the rest in the ground until spring, to be dug up as required By running a plow, such as used for breaking sod, along one side of the rows, field crops of Parsnips will be thrown out so that they can be harvested easily. Deep, rich, heavy soil is best suited for the culture of Parsnips, but on any deep, rich, mellow soil the yield is good per acre, and the roots will be smooth and large if no fresh manure is used; this tends to make them coarse-grained and misshapen. An ounce of seed will sow I50 feet of drill; five ponnds will sow an acre.

Improved Hollow Crown. The variety most widely cultivated. The roots are tender and sweet, and their yield per acre is heavy. Oz. Io cts., 1/41b. $20 \mathrm{cts}$., 1b. $50 \mathrm{cts}$.

Guernsey. The roots do not grow as long as those of the preceding, but are thicker and more easily gathered. A very heavy cropper; roots smooth; flesh fine-grained and of excellent qualit Oz. Io cts., 1/4lb. 20 cts., $1 \mathrm{~b} .50 \mathrm{cts}$.

\section{PEPPER}

\section{(Pfeffer)}

Sow in hotbed as early as April, transplant to rich, warm, mellow soil as soon as the weather has become warm and settled, setting them about 2 feet apart in drills 3 feet apart. Seed may be sown later, in the open ground, when all danger from frost is over, and thinned to the distance given above. The pods are used in making all sorts of pickles. An ounce of seed will produce 2,000 plants.

Chinese Giant. Grows very large and uniform, as early as Ruby King, and very mild. See p. 3. Oz. 5oc., 1/41b. \$I.5O, 1b. $\$ 5$.

Large Bell, or Bull Nose. Widely grown, standard old variety, with very large, thick pods. Oz. 25 c., 1/1b. 8 oc., $1 \mathrm{~b} . \$ 2.50$.

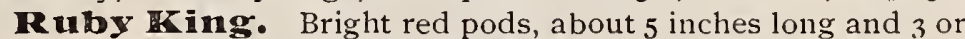
4 inches thick; mild and pleasant in flavor. Oz. $25 \mathrm{cts}$, 1/4 lb. $80 \mathrm{cts}$. lb. $\$ 2.50$.

Sweet Mountain. An early-fruiting sort; enormous, mild-flavored pods, much used for mango making and mixing with salads. Oz. 25 cts., $1 / 4$ lb. 80 cts., lb. $\$ 2.50$.

Squash. The variety generally grown for pickling; medium size, thick skin; very productive. Oz. $30 \mathrm{cts}$., $1 / 4 \mathrm{lb}$. 8o cts., lb. $\$ 2.50$

Golden Queen. Pods large, yellow; similar to Large Bell in shape, but milder flavored. Oz. 25 cts., 1/4 lb. 80 cts., 1b. $\$ 2.50$.

Long Red Cayenne.' Pods long, slender, bright red, very sharp. Oz. $30 \mathrm{cts}$., I/1b. $\$ \mathrm{I}, 1 \mathrm{~b} . \$ 3$.

Red Chili. Used for making Pepper-sauce. Pods small, conical, scarlet, pungent; plants very fruitful. Oz. $30 \mathrm{cts}$, , $1 / 4 \mathrm{lb}$. $\$ 1,1 \mathrm{~b} . \$ 3$.

Red Cherry. Pod small, round, bright red; ornamental. Oz. 30 cts., I/ $/$ lb. $\$ \mathrm{I}, \mathrm{lb} . \$ 3$

Celestial. Pretty, conical pods 2 or 3 inches long, thickly covering the plant. Creamy yellow, changing to bright scarlet, so that a plant full of fruit shows beautiful colored contrasts. $\mathrm{Oz}$. $30 \mathrm{cts}$., $1 / \mathrm{lb}$. $\$ \mathrm{I}, \mathrm{lb} . \$ 3$.

\section{RADISH (Rettig)}

Select a light, sandy loam, and sow as early as the ground can be worked in the spring. For a successive supply sow every two or three weeks.

Vick's Early Scarlet Globe (American-grown). For forcing in the greenhouse. hotbeds or coldframes, and for sowing in open borders early in the spring, there is no other red variety so desirable. It is the earliest, its color is the handsomest, in flavor it is the mildest, most crisp, juicy and tender. It forms a small top, and will stand a great amount of heat. It is the market-gardeners' favorite forcing Radish. It will sell "three to one " compared with any round red sort. Oz. Io cts., $1 / 41 \mathrm{~b} .25 \mathrm{cts}$., $1 \mathrm{~b} .75 \mathrm{cts}$.

French Breakfast (American-grown). Olive-shaped; red above and white below medium size; small top and of quick growth; crisp, sweet and tender. Oz. IOc., $1 / 1 \mathrm{lb}$. 20c., 1b. 6oc.

Long Scarlet Short Top (American-grown). Long, straight and smooth; tender while young; flavor delicate; color bright red. Oz. Io cts., r//1b. $20 \mathrm{cts} ., \mathrm{lb} .60 \mathrm{cts}$.

Early Olive-shaped Scarlet. Oliveshaped; skin bright scarlet; flesh firm and crisp. Oz. Io cts., $1 / 1 \mathrm{lb}$. $20 \mathrm{cts}, \mathrm{b}$. $60 \mathrm{cts}$.

Olive-shaped White. Has white, olive-shaped roots. Oz. Io cts., 1//1b. 20 cts., lb. 60 cts

Early Deep Scarlet Turnip. Skin deep scarlet; flesh sweet, tender, mild and crisp; quick-growing, early variety ; tops small. Oz. Io cts., $1 / 4 \mathrm{lb} .20 \mathrm{cts}$., $1 \mathrm{~b} .60 \mathrm{cts}$.

Beckert's Improved Chartier. The finest variety; as early as Long Scarlet Short-Top, but better in quality; superior to any other Radish. Oz. Ioc., 1/4 lb. 20c., lb. 6oc.

Wood's Early Frame. One of the best long varieties for forcing, also good for outdoor crops; tops small, flavor excellent; early. Oz. Io cts., 1/4lb. $20 \mathrm{cts}$., 1b. $60 \mathrm{cts}$.

Long Brightest Scarlet. Vivid scarlet, tipped with snow-white; rapid grower quality fine. Oz. 10 cts., $1 / 1 \mathrm{lb}$. $20 \mathrm{cts}$., $1 \mathrm{~b}$. fo cts.

Long Black Spanish. Roots black; flesh white and slightly pungent; one of the hardiest and latest. Oz. Io cts., I/4lb. 20 cts., lb. $60 \mathrm{cts}$

White Giant Stuttgart. Very early, and grows to a large size. Fine quality, firm and brittle. Oz. Io cts., 1/4lb. 20 cts., 1 b. $60 \mathrm{cts}$.
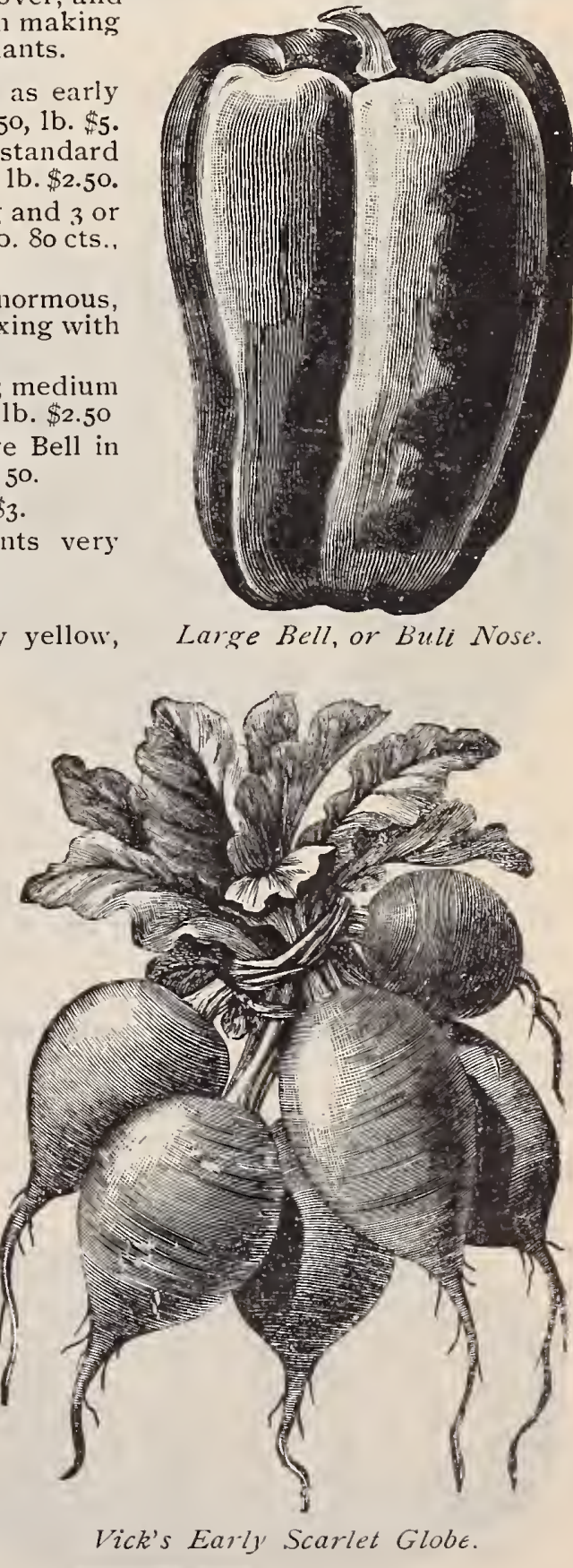

Large Bell, or Buli Nose'.

All Vegetable Seeds sold at the uniform price of 5 cts. per packet 


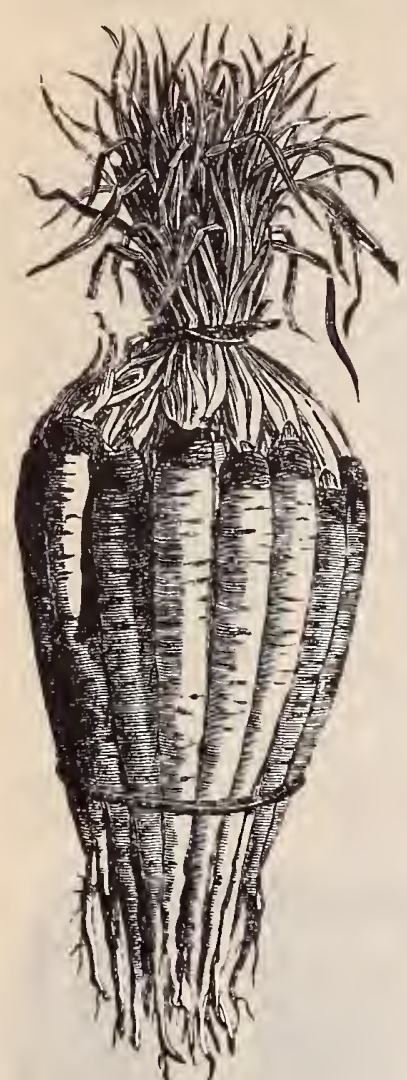

Salsify.

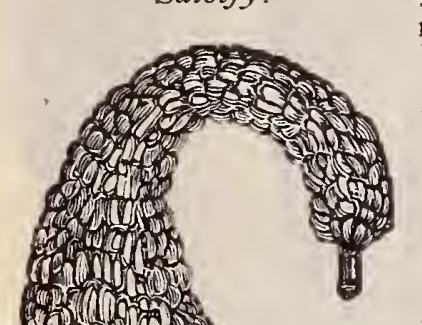

Squash seed should be planted at about the same time and in the same manner as cucumbers and melons. The hills should be 9 feet apart each way, slightly elevated and highly manured. Bush varieties may be planted closer together. Use plenty of seed, as the bugs will destroy some plants. ion of the large, dark green, warted specimens always seen in good stocks of the Hubbard. It has been bred to this type until it is so fixed that nearly all have very hard, warty shells; are of large size and of the very best quality. This strain is popular with market men. Oz. Io cts., $\mathrm{I} / \mathrm{lb}$. $30 \mathrm{cts}, \mathrm{lh} . \$ \mathrm{I}$.

The Warren. This variety resembles Turban in shape; the shell, however, is rough and warty, and much thicker and harder than in that variety. The color is richer, the quality excellent, and it is a better keeper. Oz. Io cts., I/4lb. 30 cts., lb. \$I.

Dunlap Prolific Marrow. An improved strain of Boston Marrow; fruits deeper orange, more rounded, thicker, having a smaller seed cavity and better flesh. A productive, good-keeping Squash. Oz. cts., $1 / 4 \mathrm{lb} .25$ cts., 1b. 80 cts.

Hubbard. A standard late Squash. Skin dark green; flesh fine-grained, dry, sweet, late-keeping. Oz. Io cts. I $1 / 1$ lb. $30 \mathrm{cts}$., lb. $\$ 1$.

Golden Mubbard. This is a very distinct sort of the shape and general character of the Hubbard, but a little smaller, earlier to mature and of a rich orange-red color, instead of the dark olive-green of the old Hubbard. Oz. Io cts., r/lb. 30 cts., Ib. $\$ 1$.

Delicata. Orange-yellow, striped green; small size, but very prolific; it is extra-early, very solid, and a good keeper; flesh dry and of fine quality. Oz. Io cts., $1 / 4 \mathrm{lb} .25 \mathrm{cts}, 1 \mathrm{~b} .80 \mathrm{cts}$. Faxon. The shell is unusually thin, and the flesh deep yellow, thick,
sweet and fine for pies. The Squashes vary in color from pale yellow to $\begin{array}{ccc}\text { Summer Crook- } & \text { sweet and fine for pies. The Squashes vary in color from pale yellow to } \\ \text { neck Squash. } & \text { green, mottled and striped with a lighter color. Oz. Ioc., I/4lb. 3oc., lb. \$I. } \\ \text { Bay State. Thick-shelled and thick-meated; a little smaller than }\end{array}$ Essex Hybrid; flesh dry, fine-grained and good; a good yielder. Oz. Io cts., I/4lb. 30c., lb. \$I. Mammoth Chill. Very large and nutritious, orange-colored fruits, which keep well all winter. The most profitable sort for stock-feeding. Oz. I5 cts., 1/4 1b. $50 \mathrm{cts}$, 1b. $\$ 175$.

Giant Summer Crookneck. The largest of the early Crooknecks, and as early as any; flesh tender and good, cooking quickly. O $\%$. Io cts., 1/41b. 25 cts., lb. 80 cts.

Golden Summer Crookneck. Early and productive; fruits yellow, covered with watery excrescences, as in all this race; flesh fine-grained and rich. All the Summer Crooknecks are noted for their great size and fine quality. This one is also handsome in appearance. Oz. Io cts., T/1b. 25 cts., lb. 80 cts.

Winter Crookneck. A favorite late-keeping winter Squash, with yellow skin and sweet fine-grained flesh. Oz. Io cts., $1 / 4$ lb. $25 \mathrm{cts}$., $1 \mathrm{~b}$. $80 \mathrm{cts}$.

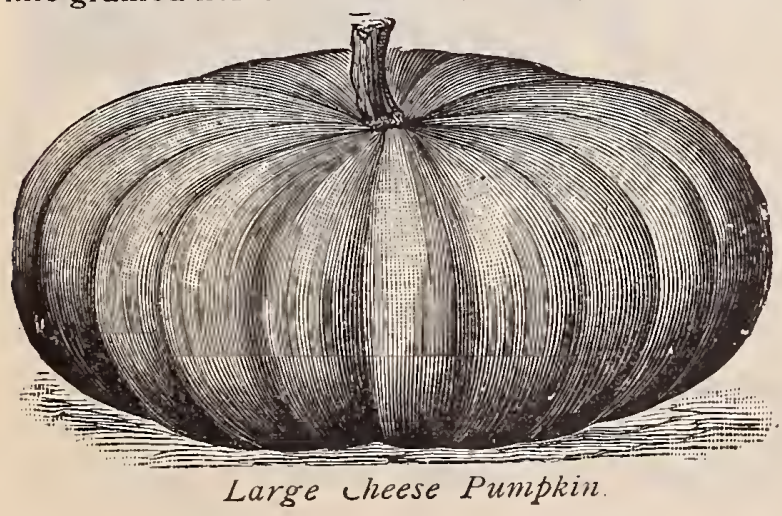

White Bush Scalloped. The earliest; skin cream-colored; flesh sweet and rich; very productive. $\mathrm{Oz}$. Io cts., $1 / 4 \mathrm{lb} .25 \mathrm{cts}$., lb. $80 \mathrm{cts}$.

Yellow Bush Scalloped. Differs from the above in color only. Oz. Io cts., $1 / 1 \mathrm{lb}$. 25 cts., 1b. 80 cts.

\section{PUMPKINS (尺urbis)}

The Pumpkin is now little used except for agricultural purposes, the squashes being so much sweeter and drier and finer grained for the kitchen. The farmer however, finds the Pumpkin a serviceable addition to his feed. The most common method of cultivation is to plant them with ccrn, two or three seeds to each hill.

Sugar. Round, not large, but very sweet, and an excellent table variety. Oz. Io cts , I/4lb. 20 cts., lb. 50 cts.

Mammoth. Grows to an immense size, often weighing over roo pounds. Oz. I 5 cts., I/4lb. 50 cts., 1b. \$I.50.

Connecticut Fleld. Very productive; largely grown for feeding stock. (Per bushel, \$5.) Oz. In cts., $1 / 4 \mathrm{lb}$. I5 cts , lb. 30 cts.

Large Cheese. Very productive. Oz. $10 \mathrm{cts}$., $1 / 4 \mathrm{lb} .20 \mathrm{cts}$, $1 \mathrm{~b} .50 \mathrm{cts}$ 


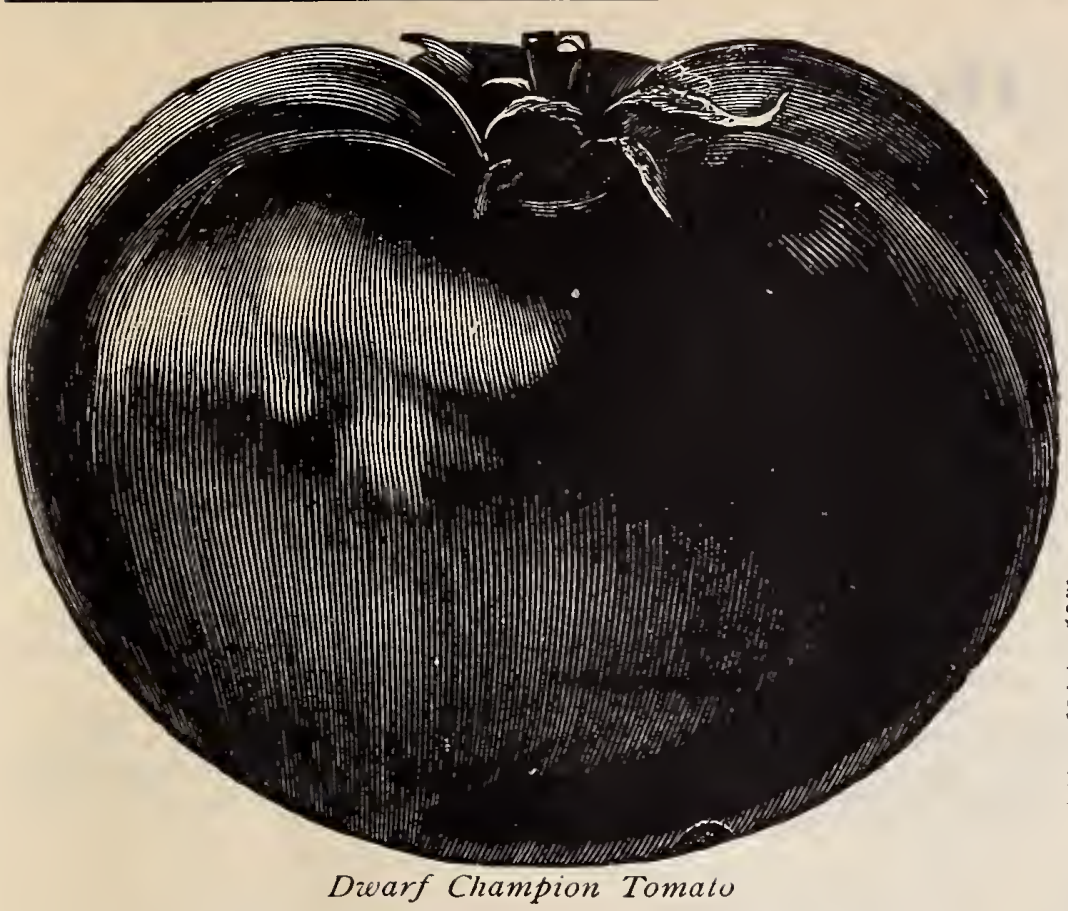

\section{Tomatoes}

(Siebesäptel)

For early use sow in February or March in hotbed or in boxes and pots set in the warm window, and hasten the germination and growth of the plants by good care and frequent watering. When the seedlings are about 3 inches high, transplant them to pots or in rows 4 or 5 inches apart, keeping the temperature at about $6 u$ degrees. Subsequent transplantings will make them branching and stocky, but do not set them in the open ground until all danger from frost is past, then plant them in a warm, sunny place, and water them freely until they are well established. Some support which will keep the fruit above the ground and free from dirt should be given the plants. An ounce of seed will produce about 2,000 plants.

Earliana. This is considered the earliest red Tomato grown. Fair size, good shape, good quality. Oz. $40 \mathrm{cts}, \mathrm{T} / \mathrm{lb}$. $\$$ r.25, lb. \$4

New Dwarf Stone. A splendid new variety put out by Livingston, sure to come to the front as a general crop Tomato. See page 3. Oz $40 \mathrm{cts}$., I/4lb. $\$$ I.25, lb. $\$ 4$.

Lorillard. A splendid sort for forcing under glass, as well as for outdoor culture; bright, glossy red, smooth; of fine flavor and very early. Oz. 25 cts., $1 / 1$ lb. 75 cts., lb. $\$ 2.50$.

Atlantic Prize. The earliest; smooth, bright red and solid. Oz. 25 cts., $1 / 4$ lb. 75 cts., lb. $\$ 2.50$.

Dwarf Champion. This Tomato has grown rapidly in popularity since its first introduction several years ago, and is now one of the most valued early market sorts. It is quite distinct in foliage and habit of growth, the plants being compact, stocky and upright, and requiring no support. Although the fruits begin to ripen very early and the plants yield enormously, they do not flag before frost; many begin to ripen their crops July $\mathrm{r}$, hold half a bushel of fine Tomatoes when at their best, and still a peck or more of fruit can be gathered from such a plant when frost comes. The fruit is always smooth and handsome, ripening close to the core and never cracking; in shape and color it resembles Acine. Oz. $30 \mathrm{cts} ., \mathrm{t} / \mathrm{lb} \$ \mathrm{I}, \mathrm{lb} . \$ 3$.

Beauty. One of the best. Fruit glossy crimson, large, smooth, solid, never cracking, and holding its size until late in autumi1. Oz. $25 \mathrm{cts}$., $1 / 4 \mathrm{lb}$. $75 \mathrm{cts}$., lb. $\$ 2$.

The Stone. This new variety bears very large, perfectly smooth fruits of bright scarlet; they are solid and meaty, with few seeds, and ship and keep well. One of the best sorts of recent introduction. Oz. $25 \mathrm{cts}$., $1 / 4 \mathrm{lb} .75 \mathrm{cts}$., $1 \mathrm{~b} . \$ 2$.

Peach. Entirely different from any other Tomato, resembling a peach in size, form and color. Of delicate flavor and very attractive in appearance. The fruit is 2 inches in diameter, and borne in large quantities; an excellent preserving sort. Oz. 25 cts., $1 / 1 / 4$ lb. 75 cts., lb. $\$ 2$.

Acme. Fruit crimson, large, smooth, solid, never cracking, and holding its size well. Oz. 25 cts., $1 / 41 \mathrm{~b} .75$ cts., $1 \mathrm{~b} . \$ 2$.

Favorite. Fruits large, smooth, solid and meaty; very productive. A good shipper. Oz. 25 cts., T/7 lb. 75 cts., lb. $\$ 2$.

Yellow Plum. Fruits yellow, used for preserves. Oz. 3o cts., 1/41b. \$1, 1b. $\$ 3$.

Grape, or Cherry Currant. Half an inch in diameter; desirable for pickles, etc. Oz. 30 cts.

Strawberry (Winter, or Ground Cherry). Small fruits enclosed in a husk; they have the flavor of strawberries, and may be preserved like plums. The vines are always heavily loaded with fruits. Oz. $30 \mathrm{cts}$.

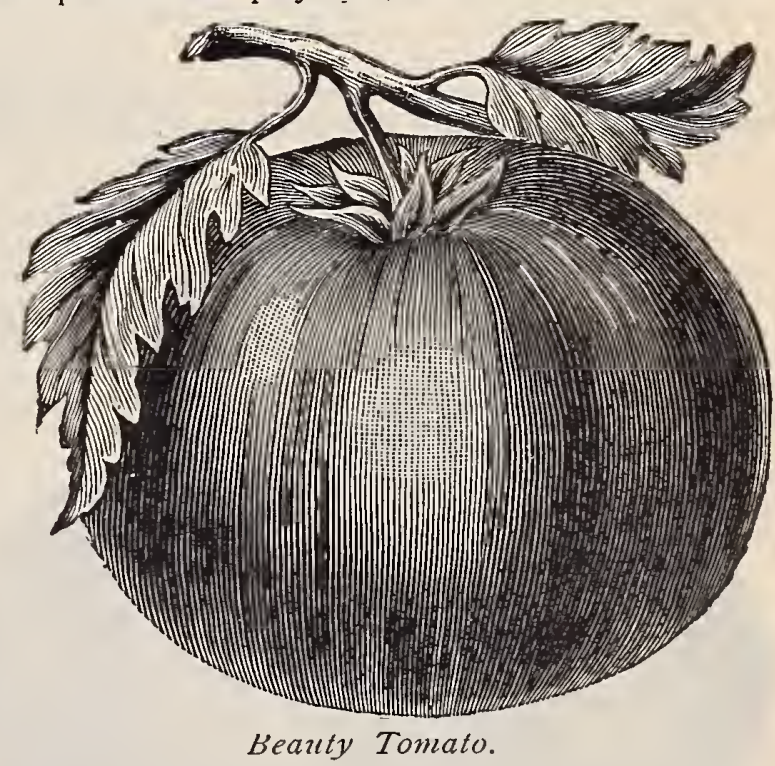

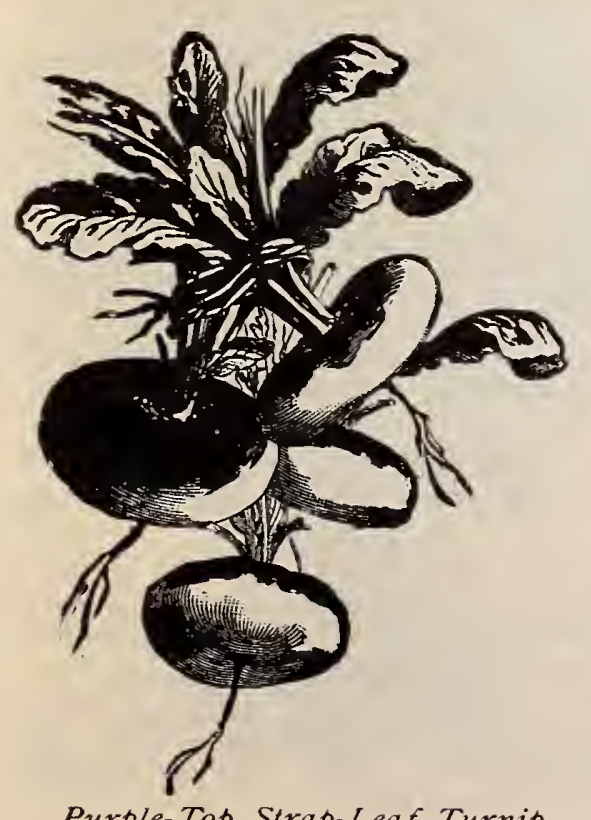

Purple-Top Strap-Leaf Turnip.

\section{The Best Turnip Seed}

\section{( $\Re$ übe)}

For early, sow as soon as the ground can be prepared, in drills 15 inches apart, and thin the plants to stand 8 inches apart. Sow for succession at intervals of a fortnight until the last week in July, and from that time onward until the last of August sow for main crop. The sowings should always be made just before a rain, if possible, as the success of the crop depends in a great measure upon quick germination and rapid growth in the young plants. An ounce of seed will sow I5o feet of drill; one pound will sow an acre.

Twentieth Century Rock. New; see description on page 3. This Turnip is now recognized as the standard winter Turnip. Oz. Io cts., 1/4 lb. $30 \mathrm{cts}$., $1 \mathrm{~b} .75 \mathrm{cts}$.

Early White Milan. Very early; pure white and of fine quality. Oz. Io cts., $1 / 4 \mathrm{lb}$.

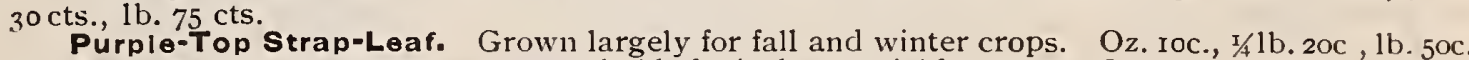

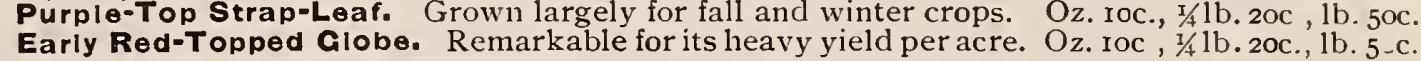
Early White Egg. Pure white, egg-shaped ; grows rapidly and is fine-grained, sweet, delicate flavored and solid. Oz. Io cts., I/4lb. $20 \mathrm{cts}, 1 \mathrm{~b} .60 \mathrm{cts}$.

Early White Dutch. Early, quick-growing and good. Oz. Io cts., 1/41b. 20 cts., 1b. 50 cts.

Cow Horn. White, fine-grained, sweet flesh. Oz. Io cts, 1/4lb. 20 cts., 1b. $50 \mathrm{cts}$.

Yellow Aberdeen. Grown for stock-feeding; roots large and solid. Oz. 1oc., $1 / 41 \mathrm{lb} .20 c ., 1 \mathrm{~b} .50 \mathrm{c}$. Large White Rock. Quality extra fine; good keeper. Oz. Io cts., 1/4lb. 20 cts., lb. 60 cts. Budiong White Rock. Obtained by years of selection from the above, growing much smoother. Oz. 1o cts., $1 / 1 / \mathrm{lb} .25$ cts., 1b. $60 \mathrm{cts}$.

Improved American Rutabaga. Large, firm, yellow roots, which keep well, are hardy and well flavored. Oz. Io cts., $1 / 1 \mathrm{lb}$. 20 cts., 1b. 5o cts.

Sweet German. Large white ; fine quality. Oz. ro cts., 1/4lb. 20 cts., lb. 50 cts, 


\section{Seeds for the Farm}

\section{FIELD BEETS}

White French Sugar. This variety is much grown in Europe for sugar-making; very sweet, and keeps well; much relished by stock. Oz. 5 cts., $1 / 4$ lb. 15 cts., 1b. 40 cts.

Mangel-Wurzel, Norbiton Giant. A long red variety, preferred by many to common Long Red, as it is considered of better keeping quality; good for deep soils. Oz. 5 cts., 1/4lb. 15 cts., lb. 40 cts.

Mangel-Wurzel, New Golden Yellow Mammoth. The flesh of this variety is a bright golden yellow ; of fine quality, and exceedingly rich in saccharine matter. Oz. 5 cts., 1/4lb. 15 cts. lb 40 cts.

Mangel-Wurzel, Golden Tankard. A most important addition to our roots for feeding stock. Flesh a deep, rich yellow, very sweet and nutritious. In shape a little shorter than the Giant, but thicker. A very heavy cropper. By many this is considered the best variety in cultivation. Oz. 5 cts., $1 / 4 \mathrm{lb}$. $15 \mathrm{cts}$., $1 \mathrm{~b} .40 \mathrm{cts}$.

Our Farm Seeds and Implements are kept thoroughly up to date and are among the best on the market.

\section{FIELD CORN}

Leaming. This is a dented flint variety. The ears are large, with deep, large grain, of dark orange color, and small red cob: stalks of medium size. Bus. \$2.

Early Yellow Canada. A very early 8-rowed variety; bears close planting, and yields numerous ears, which fill out to the extreme tip; a safe sort for high latitudes or late planting. Bus. $\$ 2$.

Early Sanford. Extensively used in various parts of New England, both for grain and as fodder and ensilage. It is of very luxuriant growth; very prolific; large stalk, with plenty of leaves, and handsome ears 12 inches long. Bus. $\$ 2$.

Longfellow. An excellent yellow variety for a main crop; ears long, sometimes I2 to I5 inches; large kernel and small cob; a sort safe to plant in this latitude; yields immense crops. Bus. $\$ 2$.

Rhode Island Whlte Cap. A well-known variety. Early, very prolific; from this is made the celebrated Rhode Island white meal. Bus. $\$ 2$.

Ensilage and Fodder Corn. The W. E. B. Co.'s "special" is selected stock of Blunt's Prolific, which not only grows a tall stalk, but said stalk has more leaves than other varieties, because they grow nearer together on the stalk, making this a most desirable fodder Corn. Bus. market price.

\section{The Best Seed Potatoes, Northern:Grown}

( Rartoffeln)

Our Potatoes are all choice, northern-grown stock, grown especially for seed. We send out no Potatoes in spring before danger from frost is past. Our prices will be as low as quality of stock will permit.

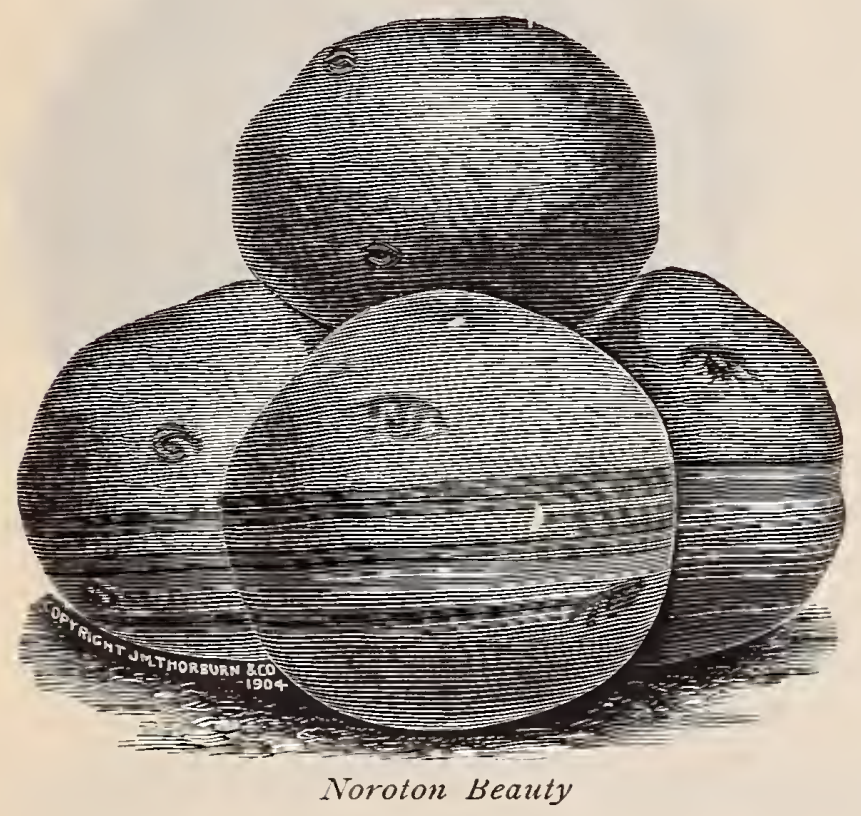

\section{Thorburn's New Potato, "Noroton Beauty" IT IS THE BEST ALL-ROUND POTATO IN EXISTENCE}

Mr. E. L. Coy, the highest American authority on Potatoes, writes of the Noroton Beauty

Esrliness-It is the earliest variety of which I have any knowledge, except one or two dwarf varieties of inferior productiveness. Planted in Washington county, $\mathrm{N}$. Y.. on May I4, they were in fine condition for the table on July 14 . No other variety planted at same time produced tubers much larger than walnuts.

Productiveness-I have never seen any extra-early variety that will yield nearly as heavily as this seedling. In fact, it will produce as heavily as any of the medium-early varieties, which is saying a great deal.

Quality-There is no variety of finer table quality. The flesh is dry, white and of superior flavor, either boiled or baked. It is of a decided sparkling, mealy texture. What is unusual, it retains its fine quality not only during the winter and spring, but as late into the summer as any of the late varieties.

vines-The tops are short, stocky and branching and completely cover the ground when planted $23 / 4$ feet each way. The stalks are quite purple when they first come up and the leaves very large and very dark green-the largest and darkest I think I have ever seen on Potatoes.

Color and shape-The ground-work of the tubers is white, slightly rusted and splashed more or less with pink and with pinkish eyes. The shape is round and exceptionally uniform.

I am much impressed with the great value of this new seedling. Too much cannot be claimed for it. It is bound to make a great sensation in the Potato world.'

Lb. 85 cts., 2 lbs. $\$ 1.50,4$ lbs. $\$ 2.75,8$ lbs. $\$ 5$, by mail or express prepaid; by express or freight, not prepaid, 1b. 75 cts., 2 lbs. $\$$ I.30, 4 lbs. $\$ 2.40,8$ lbs. $\$ 4.25$ Per peck, 15 lbs. $\$ 7$.
Norcross. A new, valuable, whi'e-fleshed variety ; large, flat oval, perfect shape. Highly recommended for main crop. Showed a yield last season of 400 bushels to the,acre.

Early Fortune. A potato grower writes; "The Early Fortune is a grand success; planted same day Early Rose was, but ripened two weeks earlier."

Early Ohlo. Is highly prized by market-gardeners, because extra-early. The supply is never equal to the demand. Orders should come early to secure good, fine stock, pure and true.

Green Mountain. A late Potato which does well on all kinds of soil ; very productive; oval in shape; good keeper ; of fine quality:

Now Queen. This is a very productive new seedling, and the best early market Potato ever sold in this country. In shape and color it resembles the Hebron.

Early Norther. A seedling from Early Rose, resembling it in shape and color; will outyield its parent 30 per cent. A strong, vigorous grower, of fine eating quality; well adapted to all soils and climates.
Bovee. This is one of the best extra-early Potatoes. It resembles the Beauty of Hebron but matures much earlier, and yields better than that good old variety.

"Carman No. 3." The best late variety ever grown. Has few and shallow eyes. The greatest yielder ever introduced. Yields few, if any, small tubers.

Houlton Early Rose. We are prepared to furmsh fine Maine and Prince Edward Island Early Rose in large lots at special prices.

Early Beauty of Hebron. Very rapid and vigorous grower ripening a week ahead of Early Rose, which it far exceeds in great productiveness and excellence for table use, either baked or boiled. A good keeper; pure white skin; flesh rich and delicate.

Early Harvest. This is one of the most promising new kinds ever introduced. It is wonderfully early. This, together with early yield, superb quality and fine appearance, makes it a most valuable sort for fi st-early marketing or for home use. 


\title{
Grass and Clover Seeds
}

\author{
All our Grass and Clover Seeds are of the finest quality. Comparisons of samples and prices invited. \\ For Special Lawn Mixture, see page 2.
}

GRASSES

For General Grass-seeding for Mowing Lands.

Sow Clover, Timothy and Red-Top mixed together. For one acre, eight pounds Clover, one-half bushel Timothy, one bushel Red-Top (chaff), or eight pounds Fancy Clear Red-Top.

Finest Mixture of Grass Seeds and Clover for Hay and Permanent Pastures

The importance to the farmer of a good selection and proper mixture of Grass seeds for the various purposes of cultivation, for mowing, for soiling, for permanent pasture, etc., cannot be over-estimated. We prepare a special mixture containing only the most suitable Grasses for permanent pastures and meadow lands, such as Orchard Grass, Meadow Foxtail, Sheep's Fescue, Rhode Island Bent, Meadow Fescue, English Rye Grass, Perennial Sweet Vernal, Red-Top and Clovers. Two to four bushels of this mixture is needed to seed an acre, according to the condition of the land.

Timothy, or Herd Grass (Phleum pratense). A well-known nutritious Grass, which on most soils will produce a better crop than any other variety. We offer a particularly choice sample of seed. Sow $1 / 2$ bus. per acre, if alone. 45 lbs. to bus.

Red-Top (Agrostis vulgaris). A valuable native permanent Grass, growing in almost any soil, moist or dry, and standing our hot climate. We received this seed in finest quality direct from the western growers. Sow 3 bus. per acre, if alone; it is generally sown mixed with Timothy, $x / 2$ bus. Red-Top and $1 / 4$ bus. Timothy. Io lbs. to bus.

Red-Top, Ciean Seed. Chaff and weeds sifted out; extra fine. Wood Meadow (Poa nemoralis). Well adapted for growing under trees and in shaded situations. Dwarf and fine-growing. Sow about 2 bus. per acre. I4 lbs. to bus.

Rhode Isiand Bent (Agrostis canina). A fine, hardy, very compact Grass; very permanent, readily forming a heavy sward; excellent for pasture. Sow 4 bus. per acre, if alone. Io lbs. to bus.

Kentucky Biue (Poa pratensis). Known as June-Grass. An early Grass of great value ; makes a close, velvety turf, and is excellent for pasture; generally sown mixed with other Grasses. Sow about 3 bus. per acre, if used alone. Finest seed. I4 lbs. to bus.

Orchard (Dactylis glomerata). One of the earliest Grasses; yields immense crops, and is excellent for pasture or hay; should be cut as it is coming into bloom, and it will produce a heavy second crop. One of the best Grasses. Sow 3 bus. per acre. I4 lbs. to bus. Perennial Rye (Lolium perenne). An early, hardy and very nutritious Grass for meadows, pastures or hay crop. Generally used with other Grasses. If used alone, sow 2 bus. per acre. 24 lbs. to bus.

Meadow Fescue (Festuca pratensis). Of great value in mixtures for permanent pastures; of excellent nutritious properties, and is much relished by live stock. Sow $2 \frac{1 / 2}{2}$ bus. per acre. 15 lbs. to bus.

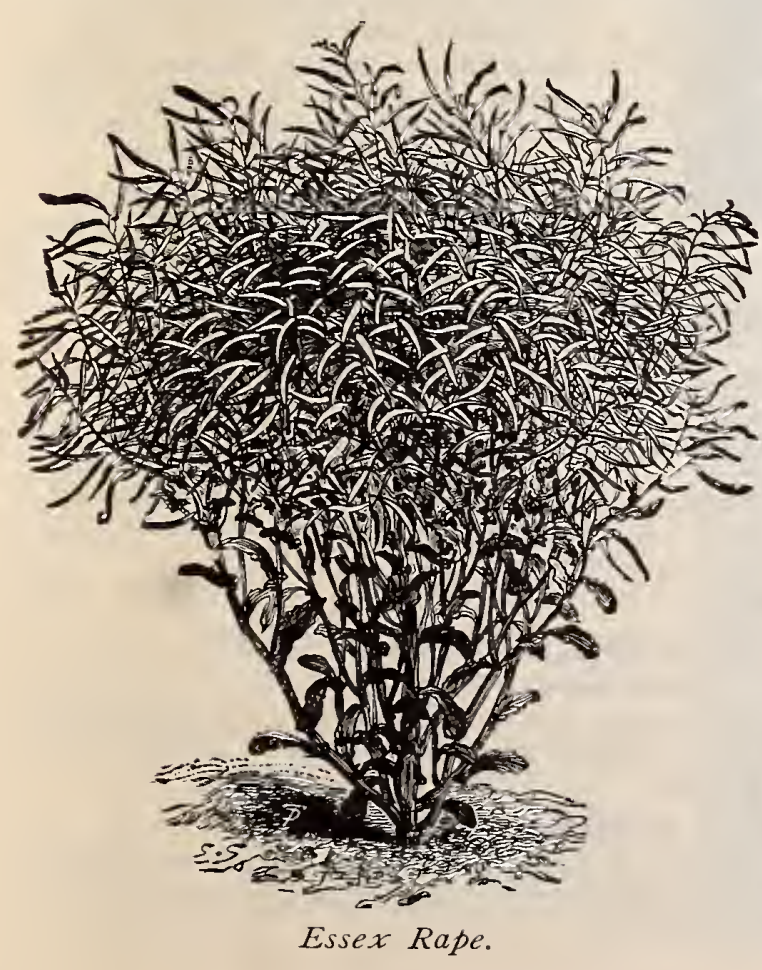
Crested Dog'sTa il (Cynosurus cristatus). A perennial Grass much valued for its dwarf habit and hardiness. One of the finest Grasses for lawns. Sow 2 to 3 bus. per acre. 28 lbs. per bus.

Tail Oat Grass ( Ave na elatior). Succeeds well in pastures with other Grasses ; makes splendid hay. Sow 4 bus. per acre. 13 lbs. to bus.

Swe t Vernai (Anthoxanthum odoratum). Useful to mix with other Grasses for lawns, in which it is invaluable on account of its early growth and fragrant odor, which it imparts to the other Grasses when drying; very hardy and permanent. I I lbs. to bus.

Meadow Foxtail (Alopecurus pratensis). Very valuable mixture for permanent pastures exposed to heat and drought; early and rapid in growth; not a valuable hay Grass. $8 \mathrm{lbs}$. to bus.

Sheep's Fescue (Festuca ovina). Of dense growth; excellent for dry situations and sheep pastures. Sow $2^{1 / 2}$ bus. per acre. 12 lbs. to bus.

\section{CLOVERS}

All carefully cleaned and selected samples. Prices variable.

New York Ciover (Trifolium pratense). Medium; finest quality. Mammoth, or Vermont Ciover. Strong-growing; heavy cropper. Aisike, or Swedish (Trifolizm hybridum). Luxuriant and sweet.

White Ciover (Trifolium repens). Excellent for lawns, as it remains green.

Lucerne, or Alfaifa (Medicago sativa). Bears heavy crops of forage; will stand cutting three or four times a season.

Crimson Ciover (Trifolium incarnatum). An annual; will flourish well on poor soil, grows about 2 feet high ; sown during July and August, often cuts Io tons of green fodder if cut from May i to io.

\section{MILLET, or HUNGARIAN GRASS}

\author{
Prices variable; subject to market fluctuations
}

Hungarian Grass (Panicum Germanicum). One of our best forage plants, and yields immensely, even when the weather is so dry that other crops dry up. One of the best annual Grasses for green fodder or hay. Sow from june i5 to July 3I. One bushel seeds an acre. 48 lbs. to bus.

Miliet, Common (Panicum miliaceum). An excellent forage plant ; very early; 2 to 3 feet high; heads open, branching panicles. Sow I to I $1 / 4$ bus. per acre. 50 lbs. to bus.

Miliet, German (Golden Millet). Of stronger and taller growth than other Millets, and does not mature so early. Sow I to $I^{1} / 2$ bus. per acre. 50 lbs to bus.

Japanese Barnyard Millet (Panicum crus-galli). This Millet is valuable as a green or dry fodder, or for siloing. It is erect in growth, very leafy, and the stalks are tender and succulent even when matured. The reported yield of green fodder is from I 5 to 20 tons per acre. For the most satisfactory results as a fodder crop this Millet must not be sown too thickly, as it stools very freely. On guod soil, when sown early, ro to I 2 quarts to the acre are sufficient. On poor soil, or if sown later sow 20 quarts. See back cover.

Wiid Rice (Zizania aquatica). A native of our northern and western states. Valuable as a forage plant for swamps and inundated lands. Before sowing put the rice in coarse cotton bags, and sink them in water for 24 hours. Sow in water which is from 6 inches to 5 feet deep, with soft mud bottom, or on low, marshy places which are covered with water the year round. In running water sow as much out of the current as possible.

Dwarf Essex Rape. Especially valuable for sheep pasturage; it is also recommended for hogs and cattle. Sow in April or August, in drills 2 or 3 pounds per acre, or 6 pounds broadcast. Dwarf Essex Rape is worthy of a trial, especially for autumn pasture in New England.

Kaffir Branching Corn, or Sorghum. Non-saccharine, but distinctly different from all others of that class. The plant is low, stocky, perfectly erect. It does not stool from the root, but branches from the top joints. The whole stalk, as well as the blades, cures into excellent fodder.

Soja hispida (Soja Bean). Resembles a bean; the haulm is stiff, the pods are produced in clusters of from two to five, and each contain four smooth, oval, nankeen-colored seeds. This plant is said to thrive well in hot and dry weather. Very valuable for the south, for either man or beast.

\section{MISCELLANEOUS SEEDS Market Price}

Bariey, Two-Rowed,
Buckwheat, Common,
"“ Japanese,
Oats, Pride of Michigan,
" Siver Maine,
Rye, Winter,
"' Spring,
Tares, or Vetches,
Peas, Canada Fieid,
"Cow,

Wheat, Winter,
“' Spring,
Rape, Dwarf Essex,
Sunfiower,
Russian Hemp,
Sicily Canary,
German Rape,
Unhulied Rice,
Flax,
Parrot Seed, Mixed.




\section{SELECT FLOWER SEEDS}

In the following pages we offer a careful and choice selection of fresh and pure Flower seeds, including the best old and new varieties. No need of the flower garden has been neglected, for seeds of plants adaptable for every ornamental purpose, covering the whole range of form and color, height and habit, and the whole season with their bloom, may be found here.

\section{DISCOUNT ON FLOWER SEEDS BY MAIL}

Our liberal discounts or premiums on Flower Seeds in packets (purchaser's selection) reduce the cost to wholesale prices. These discounts are given only on seeds sold in packets, for which in all cases the cash nust accompany the order.

We prepay postage on all Flower Seeds In packets and ounces.
This discount does not apply to assoriments or collections, nor to seeds For $\$ I$, Select Seeds amounting to

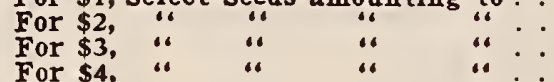

Orders by Mall

Promptly Forwarded.

\section{Choice Annuals for Bloom the First Season}

\section{ASTERS \\ Choicest New and 0ld Varieties}

The Aster is a royal annual, glorifying the garden with a rich display of bloom until the chrysanthemum, for which it is a fitting forerunner, begins to open its buds. The different forms are grown in gardens everywhere. Our collection includes the most distinct and beautiful forms and varieties of rich colors. A good selection will give elegant flowers for cutting from July until frost.

COMET. Flowers large and perfect in shape; petals long, wavy and twisted, suggestive of a Japanese chrysanthemum. The flowers, which are very handsome, average from 3 to 4 inches across, and are borne thickly on pyramidal plants from I2 to I5 inches high. Pure White, Carmine, Rose, Light Blue and Mixed. Each, ro cts. per pkt.

SEMPLE'S BRANCHING. A choice strain, which by careful selection has been brought to a high degree of perfection. Plant of branching habit, producing from ro to 20 large, perfect flowers. White, Pink and Lavender. Io cts. per pkt.

LARGE-FLOWERING VICTORIA. Immense, showy flowers, perfectly double to the center, with regularly overlapping petals; distinguished in appearance and excellent for cutting. The plants form pyramids 18 inches high, and carry 15 to 20 flowers. White, Azure Blue, Peach Blossom, Rosy Carmine, Crimson, Dark Blue and Mixed. Each, Io cts. per pkt.

PEONY-FLOWERED PERFECTION. Peerless in form, size and the rich and delicious colors of its flowers. Snow-White, Brilliant Rose, Crimson, Light Blue and Mixed. Each, $10 \mathrm{cts}$ per pkt.

MIGNON. Flowers elegant in shape, and especially useful for cutting; in form and habit the plants somewhat resemble the Victoria race, but bloom more freely. Pure White, Rose, Crimson and Mixed. Each, ro cts per pkt.

\section{ABRONIA}

Pretty trailing plants, with prostrate branches, and clusters of sweet-scented flowers, somewhat like verbenas. For baskets, rock work and borders; of easy culture, blooming profusely.

A. arenaria. Bright waxen yellow flowers. $5 \mathrm{cts}$. per pkt.

A. umbellata grandiflora. Very large, fine clusters of pure rose. 5 cts. per pkt.

\section{ADONIS}

Showy, free-blooming plants, about a foot tall, with feathery foliage and large, brilliant flowers, appearing in early spring and lasting a long while.

A. autumnalls (Pheasant's Eye). In. tense dark red, with black center. 5 cts. per pkt.

A. vernalls. See Perennials. 5 cts. per pkt.

\section{AGROSTEMMA}

(Rose Campion)

Exceedingly pretty and graceful flowers. Red, white, and red and white flowers. 5 cts. per pkt.

\section{AGERATUM}

These are greatly valued for bedding on account of their neat vigorous growth and free-blooming habit. They bloom the whole summer through, where sown early.

A. Lasseauxl. Fine clusters of bright rose, borne long and abundantly; valued for cutting. $5 \mathrm{cts}$. per pkt.

A Mexicanum, Little Dorrit, Dwarf Blue. Flowers bright blue; the plant is very dwarf, free-blooming and handsome. 5 cts. per pkt.

A. - Dwarf White. Large clusters of flowers; habit like above. 5 cts. per pkt.
Comet Asters.

\section{ALYSSUM, SWEET}

A great favorite for bouquets and house culture, as well as for outdoor baskets and border edgings.

A. Benthaml (maritimum). Trailing; flowers white, very sweet. 5 cts. per pkt.

A. compactum erectum (Little Gem). Very dwarf and spreading, covering a wide circle thickly with its white flowers, which appear when the p'ants are small. 5 cts. per pkt.

A. saxatlle compactum. See Perennials.

\section{BRACHYCOME IBERIDIFOLIA}

(Swan River Daisy)

Flowers light and graceful, and borne profusely; colors blue or white, with dark center. Plants spreading in habit, about a foot tall. Mixed, 5 cts, per pkt.

\section{BARTONIA AUREA}

Handsome, with downy foliage ; fragrant, large golden yellow flowers, which open in the evening. Thrive in any soil; height about 3 feet. 5 cts. per pkt. 


\section{SUPERB BALSAMS}

\section{(Lady's Slippers)}

Popular and easy to grow; give brilliant masses of beautiful flowers for little care. Plants about 2 feet in height ; transplanting dwarfs them and makes the flowers more double Some are as double and perfect as camellias; they range through all dark, rich, brilliant and delicate colors.

Double Rose-Flowered. Flowers very large, double, and of perfect form. Fine mixed. 5 cts. per pkt.

Improved Camellia-Flowered. Regular and perfect ; large and full to the center. Separate colors, and choice mixed. Each, Io cts per pkt.

Florists' Best Double White. Io cts. per pkt.

Mixed Double. All kinds and colors. 5 cts. per pkt.

\section{CALENDULA (Pot Marigold)}

Produces a bright and constant mass of color; grows well anywhere, and flowers until frost.

C. officinalls grandiflora fl. pl. Semidwarf plant; handsome double pure golden yellow flo.vers. The best Marigold in cultivation ; flowers very large and brilliant. $5 \mathrm{cts}$. per pkt.

Prince of Orange. Rich flowers of deep orange, striped with a lighter color; large and very double. 5 cts. per pkt.

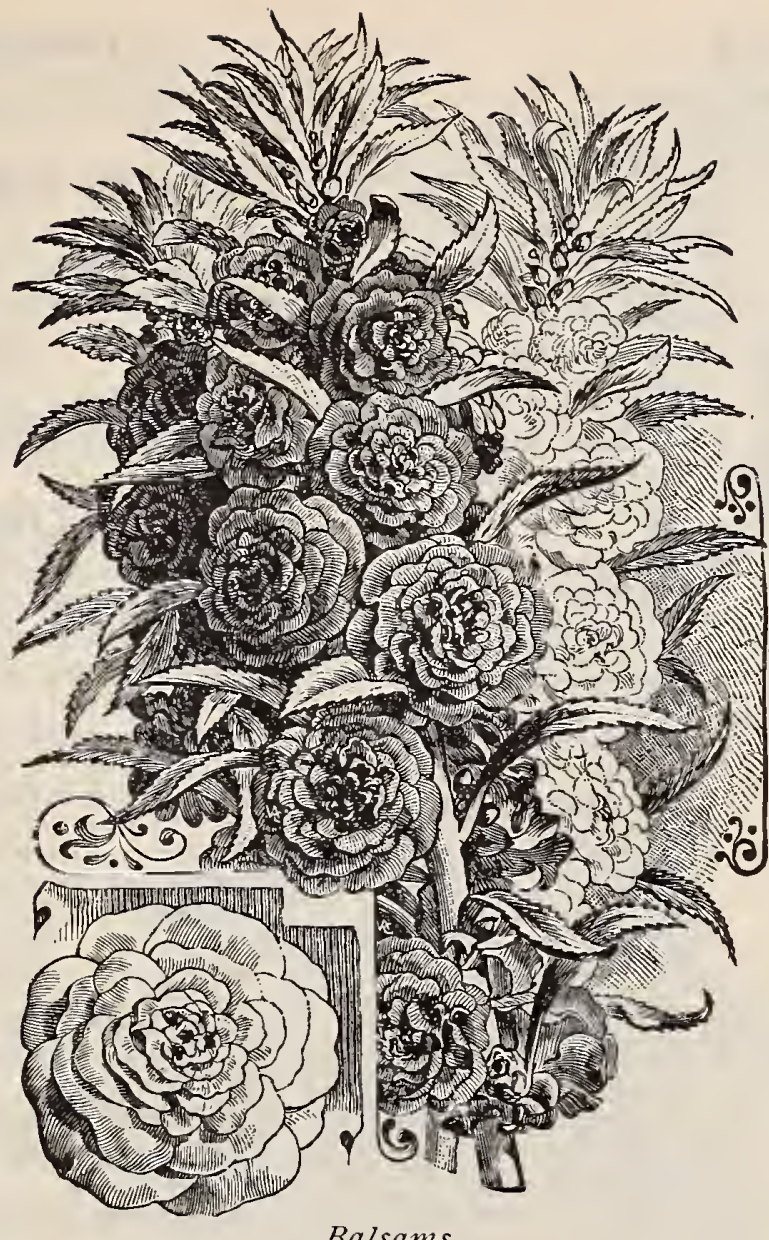

Balsams.

\section{THE CROZY CANNAS}

New Dwarf Large-Flowering French

For rich effects in bedding, the Dwarf French Cannas have now few rivals in popular estimation. As pot-plants or for winter-flowering they are also favorites. The seed should be soaked in hot water eight or ten hours before planting, and started early in hotbeds or in the house.

Fine Mixture of choice seeds, from dwarf, early-flowering plants. Ioc. per pkt.

\section{CLARKIA ELEGANS}

Early and profuse-flowering. Plants average $I \frac{1}{2}$ feet in height; oddly formed double flowers are bright rose, purple or white.

Single and Double. Each, $5 \mathrm{cts}$. per pkt.

\section{CELOSIA, or} COCKSCOMB

Tor Beds and Borders, Pot Culture and Winter Bouquets

Odd and handsome. The comb-shaped heads often attain enormous size and are always gaily colored. The plants produce finer and brighter-colored flowers if given rich soil. The dwarf varieties are much used for pot culture, and are picturesquely odd and striking in appearance; deservedly popular everywhere.

Dwarf Yellow. Splendid, brightly colored heads of large size and fine form plants strong, and but about 9 inches in height; very handsome. 5c. per pkt.

Empress. One of the handsomest ; the rich crimson heads are enormous, yet quite shapely ; plant no taller than the above. 5 cts. per pkt.

\section{CALLIOPSIS, or COREOPSIS} (Bright Eyes)

Gay and beautiful ; of graceful habit, easy culture, and flowering profusely throughout the season. As popular for cutting as for garden culture.

C. tinctoria. Flowers double, of a rich golden yellow color, with wine-maroon spots. $5 \mathrm{cts}$. per pkt.

C. Drummondil (Golden Wave). Pure bright yellow flowers, with an eye of rich, velvety brown. Compact and bushy, and blooms freely. 5 cts. per pkt.

\section{CACALIA COCCINEA (Tassel Flower)}

Loves a rich, sunny spot, where they bloom until late autumn. The tassel-shaped flowers are bright scarlet and borne in graceful clusters. $5 \mathrm{cts}$. per pkt.

\section{COLLINSIA}

Brightly colored flowers, blooming in whorls, several of which cluster about each stem. Plants continually in flower; $1 \frac{1}{2}$ feet. Mixed, 5 cts. per pkt.

\section{COSMOS}

Fine for cutting ; long, slender stems, airy, graceful flowers and feathery foliage. Plants tall and strong-growing, from 4 to 6 feet high, and a perfect fountain of bloom from September until frost. Should be started early.

White Pearl. Large, snow-white flowers. Io cts. per pkt.

Large = Flowering Pink and LargeFlowering Crimson. Each, Io cts. per pkt.

Grand Mixture. Monster flowers with frilled petals, with large, round, open petals, with irregular, laciniated petals white flowers, flecked and clouded with pink; shaded light and dark; beautiful shades of red and crimson star-like flowers, with fringed edges, pink, white, red, in endless combination. Io cts. per pkt.

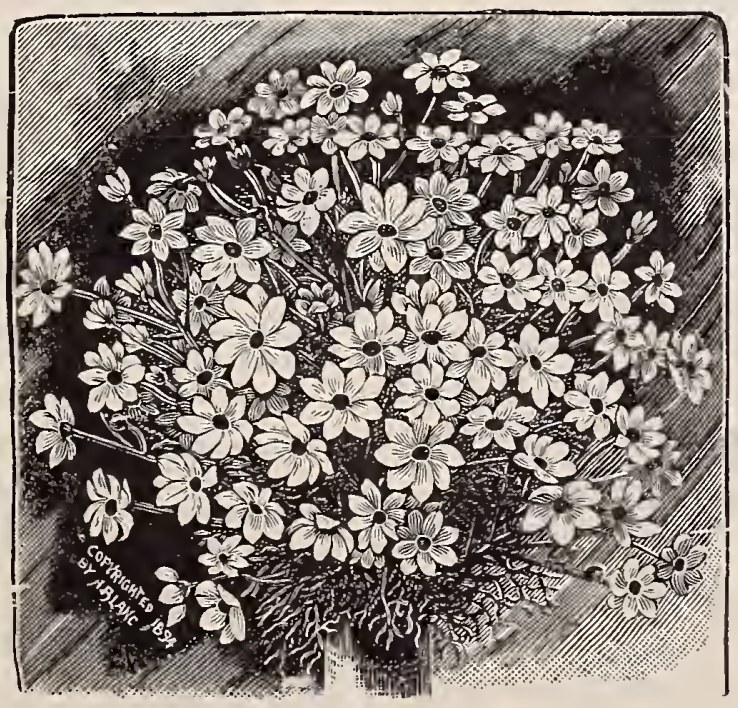

Cosmos.
Glasgow Prize (President Thiers, Tom Thumb). Quite dwarf and distinct; plants a foot high; combs fine, deep crimson. $5 \mathrm{cts}$. per pkt.

Japonica. Tall, pyramidal; flower-heads of very rich, bright scarlet. $5 \mathrm{cts}$. per pkt.

\section{CENTAUREA CYANUS (Cornflower)}

Favorite old-fashioned flowers. The quaintly pretty flowers have good stems and are brightly colored. Flowers white or blue ; plants about 18 inches tall, free-blooming. 5 cts. per pkt.

\section{CARNATIONS}

Annual Forms, Blooming Soon after the Seed is Sown MARGARET CARNATION

This new form of the hardy Carnation blooms four months from tested. Plants vigorous, semi-dwarf and neat, and if sown under glass in March or April, begin blooming in early summer and yield a brilliant display of flowers until frost. Plants which have bloomed all summer in the garden are frequently potted for winter decoration, and bloom in the window for a long time. Flowers large, quite double and perfectly formed, never bursting the calyx, and shr.w al colors and variegations through beautiful shades of red, pink and white. Fine for cutting; stems are good, and the flowers are produced in great profusion.

Pure White, Rose, Scarlet, Violet and Mixed. Each, Io cts. per pkt.

\section{CHRYSANTHEMUMS}

C. Carinatum fl, pl. Summer-blooming. The majority of the flowers are very double and bronzy yellow, tinged with red or rose, but some will be pure white or crimson, and of graceful semi-double form. $5 \mathrm{cts}$. per pkt. 


\section{DIANTHUS}

Brilliant and Popular Garden Pinks

Gay and spicily fragrant flower, well loved and grown everywhere, in almost any soil, and covering its dense thicket of leaves

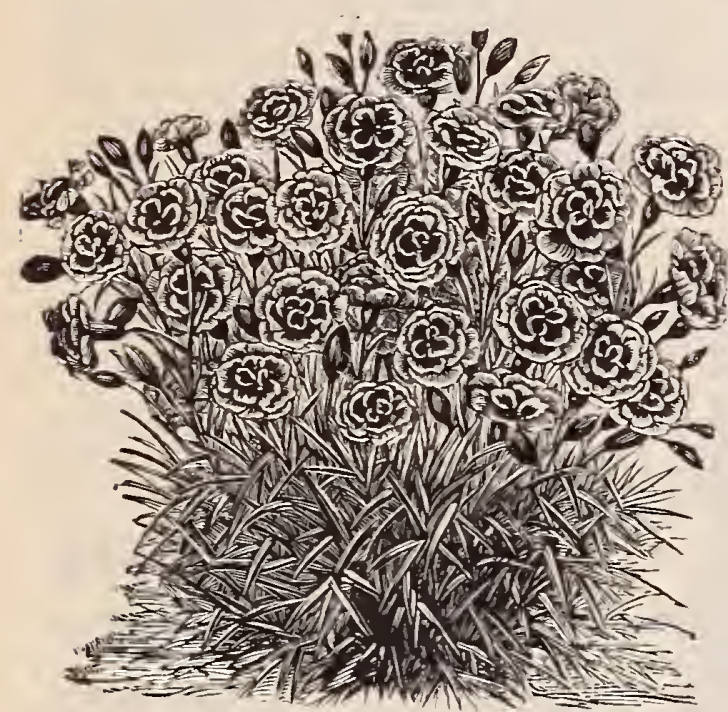

Dianthus. and stems with brilliant masses of flowers. All the varieties named below bloom the first year from seed.

D. ChInensls fI. pl. (Double Chinese, or Indian Pink). Flowers large and very double, in all rich colors. Fine mixed, $5 \mathrm{cts}$.

D. Heddewigll grandiflora fl. pl. (Crown of Perfection). Flowers of immense size and very double; produced in greatest profusion. A great diversity of colors, from purest satiny white to intense red soft pink and flesh tints, and a large proportion of flowers marked in various hues. 5 cts.

D. - Eastern Queen. A very beautiful rose variety. Ioc. per pkt. D. - Crimson Belle. Splendid brilliant dark red. $5 \mathrm{cts}$. per pkt. D. - The Bride. White, with purple center ; very pretty. 5 cts D. - diadematus fl. pl. (Double Japanese, or Diadem Pink) Flowers large and fine in form and very double, yet ranging through all colors. Finest mixed, $5 \mathrm{cts}$. per pkt.

D. Imperialls fl. pl. (Double Imperial Pink). An extra-fine mixture, producing all colors of these handsome flowers. 5 cts. per pkt. D. barbatus (Sweet William). See Perennials.

\section{DAHLIA}

Dahlias grown from seed bloom the first year. A large percentage of the double varieties come true, while the single are superb giving flowers of most beautiful form and coloring, combined with graceful habit. The seed must be started early.

Mixed Single. Seeds saved from the best named varieties. Iocts.

Mixed Double. Extra-fine mixed; will produce a large proportion of double flowers, including bright and rich colorings. Io cts.

\section{ESCHSCHOLTZIA CALIFORNICA (California Poppy)}

Brilliantly colored and poppv-like, shining with a silken luster in the sunshine. A bed of them is fairly dazzling, with its rich hues of orange, pure yellow, scarlet, creamy white, crimson and carmine. Single and double. Each, 5 cts. per pkt.

\section{GAILLARDIA (Blanket Flower)}

Showy bedding plants, averaging about 2 feet in height, and covered with flowers from midsummer until frost.

c. picta Lorenziana. Double flowers, in many bright colors. 5 cts. per pkt.

c. grandiflora. See Perennials.

\section{GODETIA}

Bright and attractive little plants, compact and branching in habit, and always gay with a crop of pretty white, rose or crimson flowers. Mixed, 5 cts. per pkt.

\section{HIBISCUS AFRICANUS?}

Showy and effective. The large, cream-colored flowers have a rich, dark brown center; the plants grow about 2 feet tall. $5 \mathrm{c}$. per pkt.

\section{IBERIS, or CANDYTUFT}

An old and universal favorite, largely cultivated, and continually in bloom; as valuable for cut-flowers as for edging and masses, and always desirable.

I. amara. Clusters of pure white. $5 \mathrm{cts}$. per pkt.

Empress. Large, handsome trusses of pure white flowers; plant strong, and of candelabrum-like habit. $5 \mathrm{cts}$. per pkt.

Tom Thumb. Very dwarf, forming a low, dense mass of green against which the large clusters of white flowers show finely. $5 \mathrm{c}$. per pkt.

\section{LUNARIA BIENNIS (Honesty)}

Hardy biennial, and must be sown in autumn or early spring for flowers the first year. Flowers white and double. $5 \mathrm{cts}$. per pkt.

\section{LINUM GRANDIFLORUM RUBRUM (Scarlet Flax)}

Of great beauty; free-flowering and easy to grow. Blosson s bright scarlet, stems and foliage fine. $5 \mathrm{cts}$. per pkt.

\section{LUPINUS (Sun Dial)}

Grows about 2 feet tall; very effective in mixed borders. The seed should be sown where the plants are to stand. Mixed, $5 \mathrm{c}$. per pkt.

\section{LOBELIA ERINUS}

The Erinus forms of Lobelia are quite showy and free-blooning. The dwarf forms are used for edgings, vases, etc., other sorts for beds. All are of easy culture.

L. ErInus (Crystal Palace Speciosa). Ultramarine-blue. Trailing. 5 cts. per pkt.

L. - speclosa superba. Dark blue, with white eye. Trailing. 5 cts. per pkt.

L. - gracilis (light blue) and albus (pure white). Trailing. Each, $5 \mathrm{cts}$. per pkt

L. compacta varieties: Albus (pure white), Crystal Palace compacta (dark blue), and Prima Donna (rich crimson). Each, Io cts. per pkt.

\section{LARKSPUR}

Rocket Larkspurs, which bloom the first season if sown early, are very showy. Flower-spikes of bright colors. For others, see Perennials.

Dwarf Double German Rocket. All colors mixed. 5c. per pkt. Tall Double German Rocket. All colors mixed. 5 cts. per pkt.

\section{MATRICARIA CAPENSIS FL. PL. (Double White Feverfew)}

For cutting and pot culture, as well as for beds and borders. Thrives well in all soils; blooms until frost. Flowers pure white, double. 18 to 20 inches tall. 5 cts. per pkt.

\section{MARIGOLD}

\section{(Double French and African)}

Showy plants for midsummer and autumn bloom. I to 2 feet tall, free-Howering and easy to grow.

Eldorado. Finest of the double African Marigolds. Flowers from Io to I4 inches across, very double, of bright golden orange and primrose shades. $5 \mathrm{cts}$. per pkt.

Tall Double French. Mixed, producing flowers of various bright colors. 5 cts. per pkt.

Dwarf Double French. Plants low and compact. Mixed, 5 cts. per pkt.

\section{MALOPE GRANDIFLORA (Mallows)}

Robust branching plants, usually about 2 feet high, with large, mallow-like red or white flowers; very pretty. Mixed, $5 \mathrm{c}$. per pkt.

\section{MIGNONETTE}

The matchless perfume of this modest flower renders it one of the most popular annuals grown. In form and color the flower-spikes have been greatly improved, but it is for their delicate, subtle fragrance that they will alway's be chiefly valued for garden and window culture, and for the costliest as well as the simplest bouquets. Defiance. New; specially adapted for pot culture. Iocts per pkt. Macnet. The best variety for pots; is dwarf and free-blooming; flower-spikes beautiful, bright reddish maroon; very sweet. ro cts. per pkt.

Large-Flowering. The old and well-known Mignonette, still as sweet as any. 5 cts. per pkt., $20 \mathrm{cts}$. per oz.

Gabrielle. Very pretty sort. bearing large spikes of red flowers. 10 cts. per pkt., $50 \mathrm{cts}$. per oz.

\section{MIRABILIS JALAPA (Four O'Clock)}

Old favorites, with sweet-scented flowers of many different colors. They open in the afternoon and wither in the morning. Mixed, 5 cts. per pkt. 


\section{MIMULUS (Monkey Flower)}

Flowers showy and oddly marked ; ground color white or yellow flaked and spotted with maroon, scarlet or crimson. Plants dwarf and compact, and bloom continuously.

M. moschatus. The well-known Musk Plant, with strongly-scented rellow flowers. Io cts. per pkt.

M. tigrinis grandiflorus. Large-flowering new tigered and spotted varieties in many rich colors. Io cts. per pkt.

\section{MESEMBRYANTHEMUM CRYSTALLINUM (Ice Plant)}

Glistening waxen leaves and stems, covered with a shining granular coat. Flowers quite pretty, and of various colors; plant trailing, about 6 inches high; well adapted for baskets, vases borders, etc. Mixed, 5 cts. per pkt.

\section{DWARF NASTURTIUMS \\ Tom Thumb Varieties, for Bedding}

None of the old-fashioned plants deserve their renewal of popularity better than the Nasturtium, so brilliant and varied in color ing, free in bloom, and picturesque in appearance. Its brave and hardy habit of growth, even in hottest suns and poor soils, once gave it the name of "the soldier's flower," which was well borne out by the rollicking air of the climbing varieties; but now the artists claim it, and its pale green, shield-shaped leaves and vivid flowers appear on all sorts of choice bric-a-brac, besides being prime favorites for cut-flower work and personal adornment. The Dwarf Nasturtiums form thick masses of leaves and flowers not more than a foot in height.

Beauty. Very bright; flowers yellow and scarlet, of the most showy description. 5 cts. per pkt., 25 cts. per $\mathrm{Oz}$.

Empress of India. A splendid dark-leaved sort, with brilliant crimson flowers. 5 cts. per pkt., 25 cts. per oz.

Golden King. Large flowers of deep golden yellow. $5 \mathrm{cts}$. per pkt., $25 \mathrm{cts}$. per $0 z$.

King Theodore. Dark, rich maroon, the petals looking as though cut from velvet. $5 \mathrm{cts}$. per pkt., $25 \mathrm{cts}$ per $\mathrm{oz}$.

Aurora. Very beautiful flowers, varying in color from primrose to pale pink, and lower petals tinged with carmine. $5 \mathrm{cts}$. per pkt., $25 \mathrm{cts}$. per $\mathrm{Oz}$

Cloth of Gold. Golden yellow foliage; light scarlet flowers; very effective. 5 cts. per pkt., 25 cts. per oz.

Prince Henry. Leaves cream-colored, marbled and spotted; bright crimson-scarlet flowers. 5 cts. per pkt., 25 cts. per oz.

Scarlet. Bright scarlet. 5 cts. per pkt., 25 cts. per $\mathrm{oz}$

Crystal Palace Cem. Sulphur, spotted maroon. 5 cts. per pkt., 25 cts. per oz.

Ruby King. Bright, ruby red. 5 cts. per pkt., 25 cts. per $\mathrm{oz}$

Superb Mixture of above-named varieties. $5 \mathrm{C}$. per pkt., 25C. per $\mathrm{OZ}$.

FINE MIXTURE of all sorts. Will produce fine flowers of many colors. 5 cts. per pkt., to cts. per oz.

For Climbing Nasturtiums, see Ornamental Climbers.

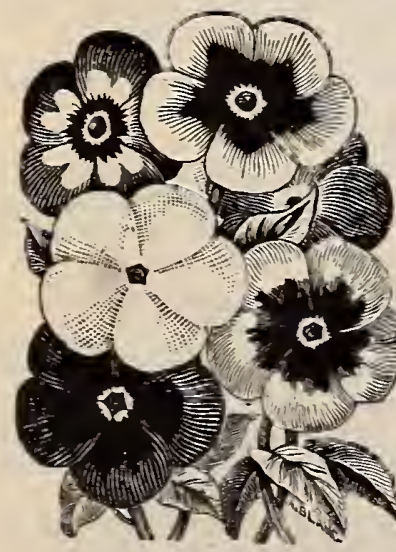

Phlox Drummondii.

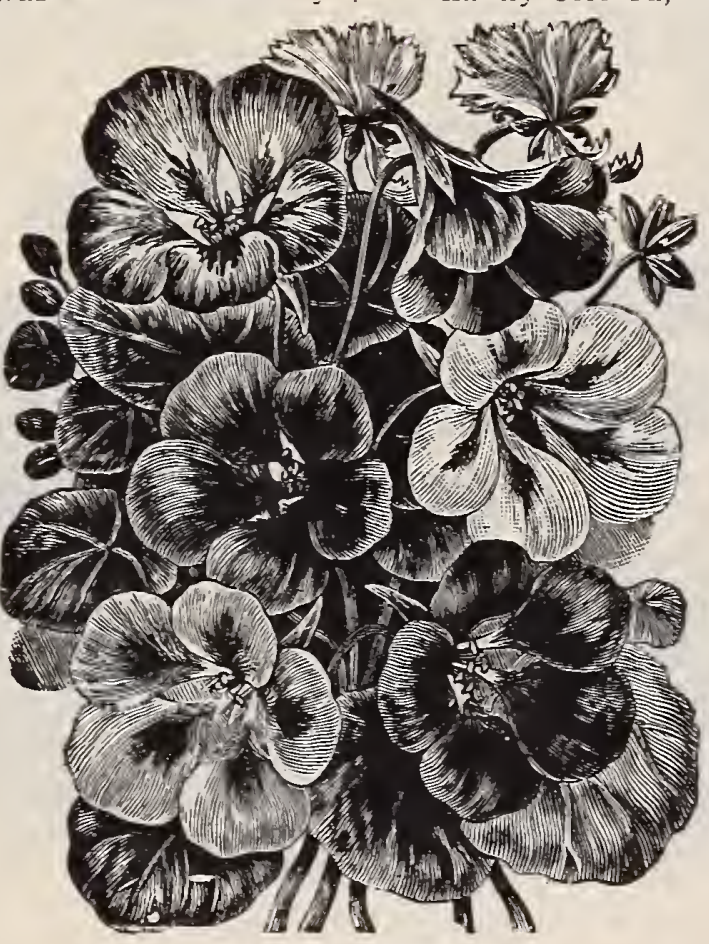

Dioarf Nasturtiums.

\section{POPPIES}

The annual poppies are quite as brilliant and effective for all purposes as the old-fashioned perennial sorts. They grow freely in any good soil.

\section{SINGLE POPPIES}

Tulip Poppy. Grows I2 to I4 inches tall, branches freely, and bears brilliant crowns of from 50 to 60 large, vivid scarlet flowers. Begin to bloom in early June and continue until late. 5 cts. per pkt.

Shirley. Semi-double, with daintily marked and colored flowers of light, gauzy appearance. Mixed, $5 \mathrm{c}$. per pkt.

Single Mixed. All the best sorts and colors. 5 cts. per pkt.

\section{DOUBLE POPPIES}

Mikado. Each blossom is a large, soft ball of finely divided petals, pure white at the base, flaming into bril-

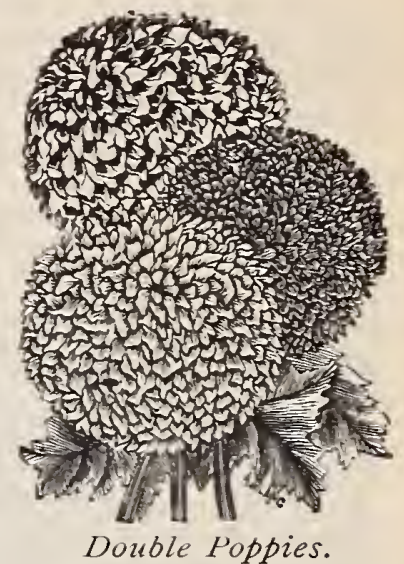

Double Poppies. liant crimson-scarlet toward the tips. $5 \mathrm{cts}$. per pkt.

Peony-Flowered Double. Large, very double and shapely, brilliantly colored, free-blooming, and more lasting than is usual with Poppies. Mixed, 5 cts. per pkt. White Swan. Very handsome, snowy flowers; graceful, of fine size, fringed and double. 5 cts. per pkt.

For other varieties of Poppies, see Perennials.

\section{PETUNIAS}

No annual of the garden is more lavish with its flowers, or more readily adaptable to any and every purpose, than the Petunia. So popular has it become that enthusiasts have given years of patient care to its improvement, and we now have superb show varieties, fringed, ruffled and double, nıottled, striped and self-colored.

\section{LARGE = FLOWERING DOUBLE} FRINGED PETUNIAS

Will produce strong, branching plants, prodigal of handsome flowers, very double and waxen, in all the best colors the lighter tinted ones are especially beautiful. $75 \mathrm{cts}$. per pkt.

\section{LARGE = FLOWERING SINGLE} FRINGED PETUNIAS

Large-Flowering Single Choicest Mixed. A choice mixtule from superb strains, combining extreme elegance of form with a great diversity of bright and delicate colors. 25 cts. per pkt.

Inimitable Striped and Blotched. Finely shaped flowers, with stelliform blotches. All sorts. Io cts. per pkt.

Good Mixed. We will give an equal percentage of all choice types. 5 cts. per pkt.

\section{PHLOX DRUMMONDII}

The Drummond Phloxes have every quality desirable in a fine bedding plant. With brilliancy and variety in color they combine grace and refinement of form, a free and constant blooming habit, neat, compact growth and ease of culture.

Phlox Drummondii nana compacta. These charming and unique Dwarf Phloxes are of neat, compact habit, growing only about 8 inches high. Choice mixed colors. Io cts. per pkt.

NIGELLA (Love=in=a=Mist)

A delicately pretty plant; light blue or white flowers, set in a mist of feathery green foliage, and bearing curious seedpods. Mixed, 5 cts. per pkt.

\section{NEMOPHILA}

Of compact habit ; oddly and beautifully colored flowers of blue, purple and white, in unusual markings and blendings. Mixed, 5 cts. per pkt.

Flowers large, fragrant and showy, white and yellow being the predominating colors, affording a fine display. Mixed, $5 \mathrm{c}$. per pkt.
P. - fimbriata. Large clusters of flowers, with fringed petals, light and effective. Mixed colors. Io cts. per pkt.

P. - cuspidata. The new Star Phloxes. Pretty star-shaped flowers, forming a lace-like cluster. Io cts. per pkt.

\section{PHLOX DRUMMONDII, LARGE=FLOWERING Flowers as Large as in the Perennial Class}

Phlox Drummondil grandiflora alba. Pure white. Io cts. per pkt. P. - - striata. Richly striped with red and rose. Io cts. per pkt. P. - - Isabellina. Flowers yellow; distinct and new. Ioc. per pkt. P. - - kermesina splendens. Vivid crimson, white eye. roc. per pkt. P. - - Mixed Varieties. All varieties mixed. $5 \mathrm{cts}$. per pkt. 


\section{Pansies}

We wish to call especial attention to our large and fine assortment of Pansy seed, which includes all famous and distinct largeflowering strains, and in separate colors all the nıost desirable shades and blendings. The collection is quite complete, and contains only the finest and purest strains.

A garden without Pansies is an anomaly now-a-days, for their bewitching flower-faces are grown and loved everywhere. The plants will live on from year to year, like other species of Violets, but the flowers become smaller as the parent stem grows older, and so for a continual supply of flowers, the seeds are sown twice a year -in spring and autunn.

Fine Mixture. A good strain of fine colors. 5 cts. per pkt.

Finest German Mixed. From a splendid strain of large-flowering and finely blotched varieties, Io cts. per pkt.

Large-Flowering Prize. Finest mixed. Special mixture prepared by ourselves, which embraces the most striking and beautiful colors. Io cts. per pkt.

English Show. From a celebrated English grower; choice strain. I5 cts. per pkt.

Bugnot's Superb Blotched. Very beautiful; extra large-flowering variety. $15 \mathrm{cts}$. per pkt.

Odier. A distinctly blotched variety of great beauty. I5c. per pkt.

Trlmardeau, or Giant Pansies. Beautiful class of vigorous growth, and flowers of enormous size; finest strain. Io cts. per pkt.

Cassier's. A splendid strain ; beautifully marked, large flowers. I5 cts, per pkt.

Giant White. With purple eye; very beautiful. Ioc. per pkt.

Glant Yellow. Black center. Io cts. per pkt.

See that your garden has a fine bed of Pansies.

\section{PORTULACA}

Sturdy little trailing plants, that bloom brightest during our warmest, driest weather. Beds of them form brilliant rainbows of color on sunshiny mornings ; the sun cannot be too warm for them.

Single Mlxed. In many rich colors. 5 cts. per pkt.

Doubie Mixed. A large percentage of the flowers will be as double as little roses. Io cts. per pkt.

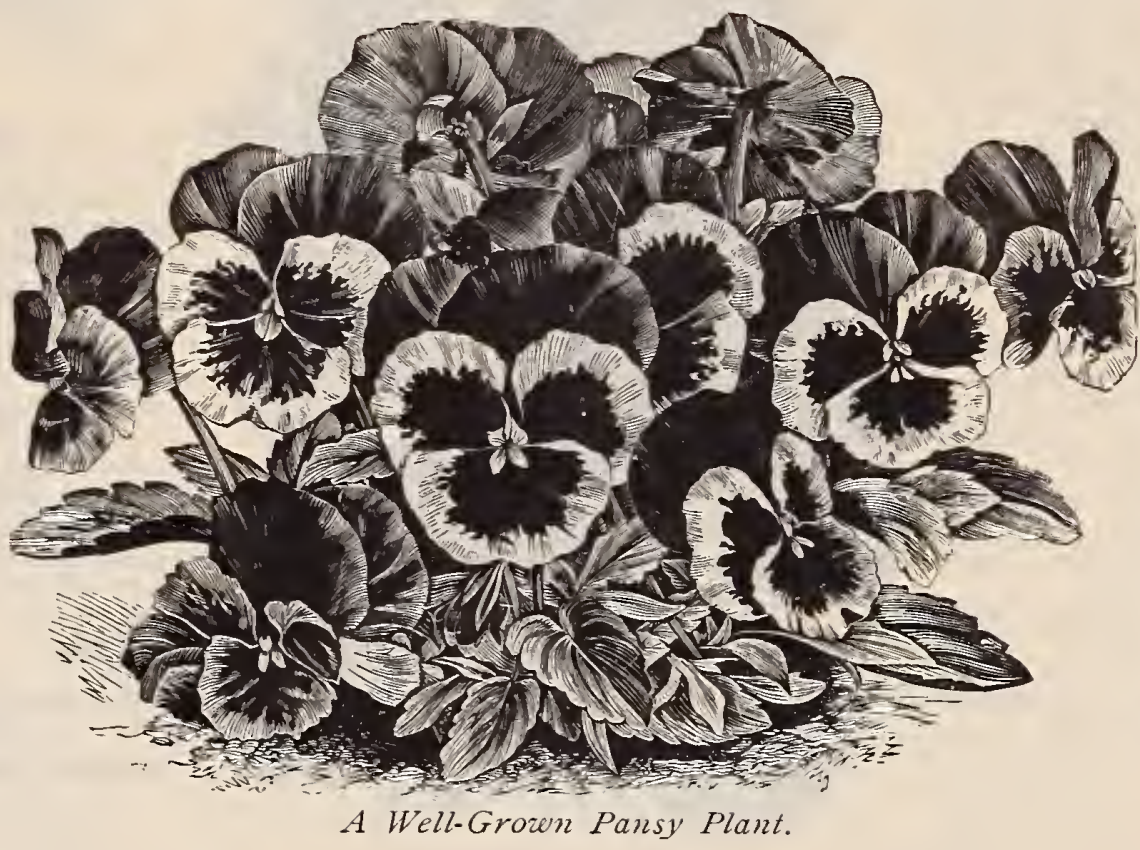

\section{STOCKS}

\section{For an Early and Profuse Display of Brilliant Flowers}

Fragrant and free-blooming, and easy to grow, either in beds or pots. Almost all the varieties have long, handsome spikes of flowers, which are admirable for cutting, and remain fresh a long while. The Ten-Weeks Stocks are especially popular, because they bloom so soon after the seed is sown.

Dwarf Queen. Dark blood-red; same habit as Snowflake. Io cts. per pkt.

snowflake. Very early flowering, and indispensable for forcing. Vigorous dwarfs of the Wallflower-leaved section ; produce long spikes of large, double, snow-white flowers. Io cts. per pkt.

\section{LAR.GE=FLOWERING TEN=WEEKS STOCKS}

The plants flower to to I 2 weeks after the seed is sown. We offer a magnificent strain of this in separate colors: Pure White, Flesh colored, Chamois-Buff, Carmine, Dark Crimson, Dark BloodRed, Light Blue, Chestnut-Brown, Pink, Scarlet, Dark Blue. Io cts. each; Mixed, Io cts. per pkt.

CUT-AND-COME-AGAIN Stocks. An unusually free-blooming species. The plants grow about 2 feet high, and send out numerous side branches, each of which bears a cluster of pure white. fragrant flowers, beautifully shaped and very double. From spring until late in fall the plants are covered with flowers, and they thrive equally well in pots or beds. Io cts. per pkt.

\section{VIRGINIAN STOCKS (Malcolmia)}

Pretty, profuse-flowering little plants, about 3 inches tall, with clusters of red and white flowers. $5 \mathrm{cts}$. per pkt.

\section{SALPIGLOSSIS GRANDIFLORA}

This elegant half-hardy annual flowers in late summer and autumn. The blossoms are velvety, with deep veins and markings, lily-shaped, and quaintly lovely. Ilixed, 5 cts. per pkt.

\section{SALVIA (Flowering Sage)}

Magnificent bedding plants, all ablaze with long spikes of blue or scarlet flowers from June until October. I to 2 feet tall.

s. splendens. Flowers bright scarlet; a general favorite. Io cts. per pkt.

s. patens. Leaves silvery; flowers large, and beautiful sky-blue. I5 cts. per pkt.

\section{SAPONARIA CALABRICA (Bouncing Bet)}

A hardy annual, growing into thick clumps, and producing masses of fragrant red, cruciform flowers. 5 cts. per pkt.

\section{SCABIOSA GRANDIFLORA (Mourning Bride)}

Curious and pretty; an old-fashioned flower, still deservedly VERBENAS

\section{Seedling Verbenas are} more robust in growth and produce larger and finer flowers than those grown from cuttings, and the light-colored varieties frequently have fragrant flowers when grown from seed. This is one of our brightest and best bedding plants, and its fine trusses of flowers represent every shade of every color except yellow. Plants from seed sown early in spring keep their beds gay with flowers from midsummer until frost; they are trailing in habit, and wide-spreading, loving a rich, sandy soil, plenty of room and full sunshine. No finer seed than ours can be procured anywhere.

Verbenas, MAMMOTH VARIETIES. This superb strain is a great improvement on the older varieties, both in size and color of flowers and habit of plants. The florets average an inch in diameter, and have clearly defined margins and large white centers. The trusses are large in proportion, and borne in great profusion upon robust, vigorous plants. Seed from finest flowers. White, Scarlet, Pink and Mixed, each Io cts. per pkt.

v. nana compacta (New Dwarf Varieties). Of very dwarf and spreading habit, requiring no pegging down. Mixed seed, Io cts. per pkt.

V. Choice Mixed. Seed saved from finest flowers. 5 cts. per pkt.

\section{VISCARIA}

Abundant bloomers. Plants about a foot in height; flowers all tints and shades of red, from scarlet to pale rose and pure white. 5 cts. per pkt.

\section{ZINNIA ELEGANS (Youth and old Age)}

All of them, but especially the dwarf sorts, give gay effects in bedding. The taller sorts are very useful for mixed borders or massing in large clumps.

Zinnia grandiflora plenissima (The new Giant Zinnia). Very large and double flowers of handsome form, in all the rich Zinnia colors; plants strong, erect and branching. $5 \mathrm{cts}$. per pkt.

Z. parviflora (The Lilliput-Flowered Zinnias). Tiny flowers of double, perfect form; unique and charming for bouquets. All colors. 5 cts. per pkt.

Z. elegans, Double Mixed. Many kinds and colors. 5c. per pkt. Z. - Curled and Crested. Finely varied flowers. $5 \mathrm{cts}$. per pkt. 


\section{Seeds of Hardy Perennials}

\section{MANY PERENNIALS BLOOM THE FIRST SEASON IF SOWN EARLY}

The permanent character of the Hardy Perennials, which live and bloom from year to year for an indefinite period, with but little care, renders them very popular among all classes of gardeners. Some of our very finest flowers are to be found among these plants for the hardy garden, many of which, though old-fashioned, are dear through associations.

\section{ACONITUM NAPELLUS GRANDIFLORUM}

(Monkshood)

Curious, helmet-shaped flowers, quite pretty and striking, produced on tall racemes above the finely cut foliage. Very prodigal of its unusually large, bright blue flowers, which last from midsummer until late in autumn. Io cts. per pkt.

\section{ADONIS VERNALIS}

A bright, early spring plant, with large, showy flowers of sunshiny yellow. $5 \mathrm{cts}$. per pkt.

\section{ALYSSUM SAXATILE COMPACTUM}

Low-growing, with light green, silky foliage and golden yellow flowers. Very useful for shaded places. 5 cts. per pkt.

\section{ANEMONE}

Old favorites, and among our earliest spring flowers. Various shades of scarlet, purple, blue and white, sometimes striped.

Fine Mixed. 5 cts. per pkt.

\section{ANTIRRHINUM (Snapdragon)}

Bloom the first year if sown early, and make very bright and showy bedding plants. Varieties with dark flowers are rich and velvety in depth of color. The dwarf sorts grow only 6 or 8 inches tall; other species about a foot high.

Tall Mixed. Seed from fine flowers of best colors. 5 cts. per pkt. Tom Thumb, Mixed. All colors; fine for bedding. $5 \mathrm{cts}$. per pkt.

\section{AQUILEGIA (Columbine)}

Very handsome and free-blooming. Bear curiously shaped flowers in many bright and delicate colors. Grow about 2 feet tall, and display their flowers well against a mass of light and pretty foliage. Aquilegia chrysantha. Gold-spurred. New, and much admired flowers large, and bright golden yellow. Io cts. per pkt.

A. grandiflora alba. Large, snow-white flowers, with long spurs. Io cts. per pkt.

A. vulgaris fl. pl. Double varieties mixed. These will give an abundance of odd and very pretty flowers. $5 \mathrm{cts}$. per pkt.

\section{AURICULAS, or HARDY PRIMULAS}

Cowslips, or Hardy Primroses, are favorite early spring flowers, with clusters of bright blossoms in different shades of red and yellow. The clumps increase rapidly.

Primula auricula. Mixed seed of best varieties. Io cts. per pkt. P. vulgaris. The true, fragrant yellow Primrose. Io cts. per pkt

\section{CAMPANULA (Bellflower)}

Very popular for mixed beds and borders. They bear a profusion of large, bell-shaped flowers in blue, rose, pink and white. Campanula pyramidalis. Flowers in many shades of blue. Mixed, $5 \mathrm{cts}$. per pkt.

C. Meadia calycanthema (Cup-and-Saucer). Handsome flower in many tints of blue, rose and white. Mixed, $5 \mathrm{cts}$. per pkt.

c. - (Canterbury Bell). Produces large, nodding, bell-shaped flowers of charming form and many beautiful shades ; single and double. Each, 5 cts. per pkt.

\section{DELPHINIUM}

Indispensable to the hardy garden, because of their long and graceful spikes of bright blue flowers.

Delphinium formosum. Rich blue flowers, with white centers. Splendid mixture, 5 cts. per pkt.

\section{DIANTHUS, or PINKS}

Dianthus Barbatus (Sweet William). Attractive, profuse-blooming garden plants. The flowers have a quaint perfume.

D. - Single Mixed. All the best colors, 5 cts. per pkt.

D. - Double Mixed. Seed from fine double flowers of many colors. Io cts. per pkt.

D. Gardnerianus (Double Hardy Garden, or Grass Pink). This species is in perfection about the first of June. The plant is hardier than the carnation. 5 cts. per pkt.

D. plumarius (Double Pheasant's Eye Pink). Double fringed flowers, fragrant, of white, crimson or purple. Io cts. per pkt.

\section{BELLIS PERENNIS}

\author{
(Double English Daisy)
}

This dainty little flower is a favorite everywhere. It is of easy culture, and grows well in all soils, if given a rather moist, shaded situation. Flowering plants grow readily from seed sown in the border in early spring, or in boxes in the house. They seldom exceed 6 inches in height, and bloom from spring until midsummer; in some localities sparingly in autumn. An exquisite plant for shady borders and edgings to beds, or for window-boxes in a cool room where in winter fiowers are sent up thickly, forming rainbows of pink and white.

Bellis perennis $\mathrm{fl}$. pl. F low ers double. Mixed colors. Io cts. per pkt.

B. - Longfellow. The bright rose-colored

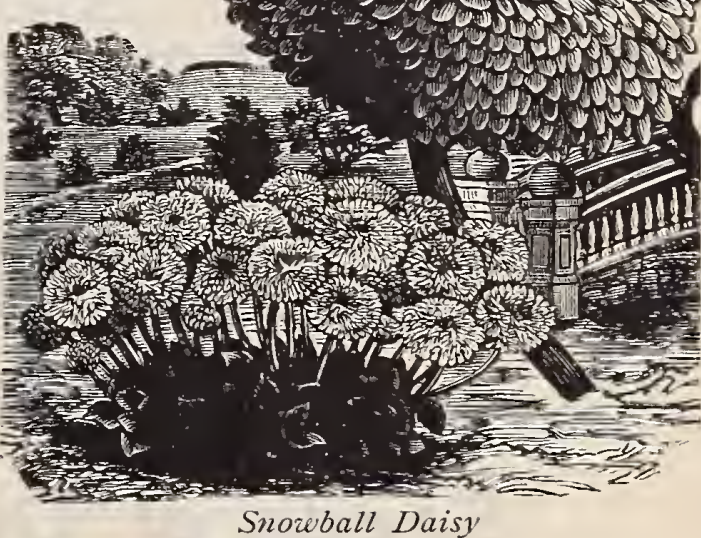
flowers are very large and double, and borne on long, stiff flower-stalks; an exquisite flower for cutting. Io cts, per pkt.

B. - Snowball. A pure white variety of the Daisy, with flowers very large and perfect, and long stems. Io cts. per pkt.

\section{DIGITALIS, or FOXGLOVE}

A stately, handsome plant, from 3 to 4 feet high. Its fine waxen flowers droop gracefully from long spikes, upon which they are set thickly. Among shrubbery, or as a background for lower plants, it gives great satisfaction. Mlixed, 5 cts. per pkt.

\section{GAILLARDIA GRANDIFLORA}

Splendid new perennial variety, with very large, handsome flow ers, having dark crimson centers marked with rings of many brilliant colors. Io cts. per pkt.

\section{GYNERIUM ARGENTEUM (Pampas Grass)}

The silvery plumes are very light and graceful in effect, and are much used for all sorts of indoor decoration. For clumps upon lawns the plant is elegant and striking, and usually grows from 6 to 8 feet high. Requires winter protection. 5 cts. per pkt.

\section{GYPSOPHILA PANICULATA (Baby's Breath)}

A dainty, mist-like plant, with sprays of small, white, star-shaped flowers and delicate foliage. $5 \mathrm{cts}$. per pkt.

\section{HOLLYHOCKS}

Chater's Superb Strain; Fine Colors in Separate PKts.

Stately and handsome old-fashioned plant. Ot late years it has been greatly improved, and its tall spikes of double silken flowers are magnificent when grown either in clumps or lines. Chater's Hollyhocks are famous everywhere as the finest strain grown.

Separate Colors. Pure White, Scarlet, Golden Yellow, Peach,

Pink, to cts. per pkt. The 5 varieties for $40 \mathrm{cts}$.

\section{LAVANDULA VERA (Lavender)}

Grown for its fragrant leaves and flowers, which retain their fragrance when cut and dried. $5 \mathrm{cts}$. per pkt.

\section{LOBELIA CARDINALIS (Cardinal Flower)}

Long spikes of intense scarlet flowers ; one of the most brilliant plants in cultivation. Suitable for all situations. Io cts. per pkt.

\section{PERENNIAL PHLOX (P. decussata)}

Fine clumps of these plants form magnificent lawn and garden ornaments, and nearly all bright colors are represented in the large and handsome flower-beds. Dwarf and tall, each to cts. per pkt.

For Drummond Phloxes, see Annuals. 


\section{MYOSOTIS (ForgeteMesNot)}

Thrive best in moist, shaded places, forming neat, compact little plants, bright with graceful sprays of starry blue flowers, which

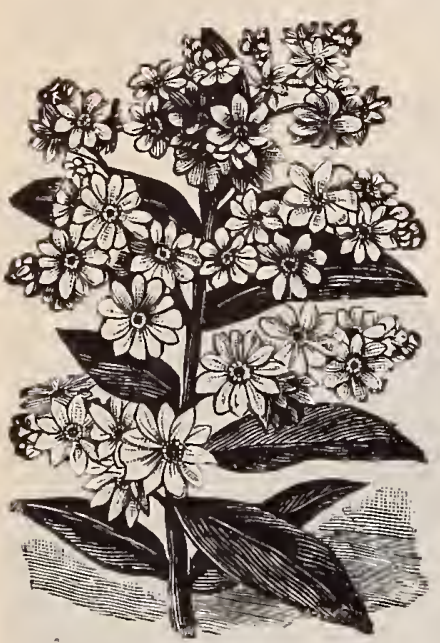

Myosotis. form one of the chief attractions of the garden in early spring. For pot culture, too, they are very pretty, if given cool treatment, and frequently bloom the first season.

Myosotis palustris (the true For get-Me-Not). Flowers bright blue, with a large golden yellow eye. Io cts. per pkt.

M. alpestris Victoria. A new dwarf variety, which forms shapely, rounded plants, and is well adapted to pot culture, although it loves the hardy green quite as well. Its sky-blue flowers are borne in thick clusters, the center ones being double. Ioc. per pkt.

M. rosea. A new rose-colored variety of the Victoria. Io cts. per pkt.

\section{PENTSTEMON} (Beard Tongue)

The flowers are borne in graceful spikes. The plants are herbaceous, and bloom from early summer until frost. The flowers are white, b!ue, scarlet, crimson, yellow, etc. Mixed, Io cts. per pkt.

\section{SWEET WILLIAM}

See Dianthus barbatus.

\section{PAPAVER ORIENTALE}

Large, brilliant flowers, rich and bright in their color. The loose, silken petals have each one a blotch of black at the base. The plants are about 2 feet high, and entirely hardy. $10 \mathrm{cts}$. per pkt.

\section{SILENE (Catchfly)}

Appear in early spring, and last until the late autumn; vary in height, color of flowers, etc., but all free-blooming; well adapted to exposed borders, etc. Mixed, $5 \mathrm{cts}$. per pkt.

\section{VIOLA ODORATA}

\section{(Sweet=Scented Violet)}

Well-known, delightfully fragrant little flowers, which bloom most freely in early spring and fall. The seed should be sown early. Mixed, to cts. per pkt.

\section{WALLFLOWERS}

\section{(Chionanthus)}

Their exquisite perfume and their rich, quaint, bright colors, usually brownish red, yellow and violet, should give them a place in every garden. When grown in the open ground the plants should be potted in autumn. Will bloom in winter if kept cool.

Double Mixed. This variety gives fine flowers in all the Wallflower colors. Io cts. per pkt.

Single Mixed. This seed is chosen from select plants of best colors. 5 cts. per pkt.

\section{Seeds of Ornamental Foliage Plants}

\section{FOR SUMMER BEDDING, BORDERS AND POT CULTURE}

We include in this department all the best ornamental foliage plants largely used in outdoor bedding. More tender sorts, useful chiefly for house and conservatory decoration, will be found under Seeds of Greenhouse Plants.

\section{ACANTHUS LATIFOLIUS}

A tall, herbaceous plant of beautiful and stately habit, grown, like the ricinus, for its rich tropical leafage. Handsome and effective, whether grown as a center for foliage beds or as a specimen plant for lawns and borders. Io cts. per pkt.

\section{AMARANTHUS}

Tall-growing plants, with showy leaves, variegated with many shades of red, yellow and green, and long racemes of curious flowers. Amaranthus caudatus (Love-Lies-Bleeding). Three feet tall; blood-red. 5 cts. per pkt.

A. cruentus. The well-known Prince's Feather. 5 cts. per pkt.

A. Henderi. Of beautiful habit; brown, dark red and bronze. 5 cts. per pkt.

A. nobilis pyramidalis. $5 \mathrm{cts}$. per pkt.

A. tricolor (Joseph's Coat). Leaves a beautiful mosaic of color. 5 cts. per pkt.

\section{BEET}

Ornamental-Foliaged, Best. In various colors. $5 \mathrm{cts}$. per pkt.

\section{CENTAUREA (Dusty Miller)}

Silver-leaved and indispensable for ribbon beds and borders, their soft, natural tints of grayish green being very effectual in toning down and harmonizing contrasts in more brilliant leaves.

Centaurea candidissima. Leaves broader and whiter than in any other silver-leaved sort. Io cts. per pkt.

C. gymnocarpa. Of very graceful growth ; a fine variety. Io cts. per pkt.

\section{COLEUS}

The leaves are of many shapes and bright colors, and nearly all varieties have a rich, velvety appearance. Seed sown in March or April will produce fine plants for bedding. $15 \mathrm{cts}$. per pkt.

\section{CINERARIA MARITIMA CANDIDISSIMA}

Another fine silver-leaved plant, used in ribbon-bedding, vases, etc. Leaves are silvery white; flowers yellow. 5 cts. per pkt.

\section{EUPHORBIA (Painted Leaf)}

Euphorbia heterophylla. Glossy green leaves, forming large bracts on the ends of the branches, changing in midsummer to brilliant scarlet. Io cts. per pkt.

E. variegaia (Snow-on-the-Mountain). Of robust growth, with fine green leaves, striped with white. 5 cts. per pkt.

\section{PERILLA NANKINENSIS}

A beautiful plant; leaves rich, dark purple; fringed. Contrasts with silver-leaved foliage plants. A half-liardy annual. 5 c. per pkt.

PYRCTHRUM AUREUM (Golden Feather)

Golden yellow foliage, finely cut, producing rich, soft effects in bedding; hardy annual. $5 \mathrm{cts}$. per pkt.

\section{RICINUS}

\section{(Castor=Oil Bean)}

Plants of stately growth, with fine fruits and leaves.

Ricinus Borboniensis ar boreus. Growth 15 feet ; leaves enormous. 5 cts. per pkt.

R. Cambodgensis. Redblack stems ; very dark leaves ; very distinct. 5 cts. per pkt.

R. Gibsoni (Duchess Edinburgh). Dark purple leaves and stems. 5 cts. per pkt.

R. Zanzibariensis. An entirely new and distinct class. The plants attain great dimensions, presenting a splendid aspect with their gigantic leaves. Seeds also very distinct, very large and of exquisite tints. Mixed, 5 cts. per pkt.

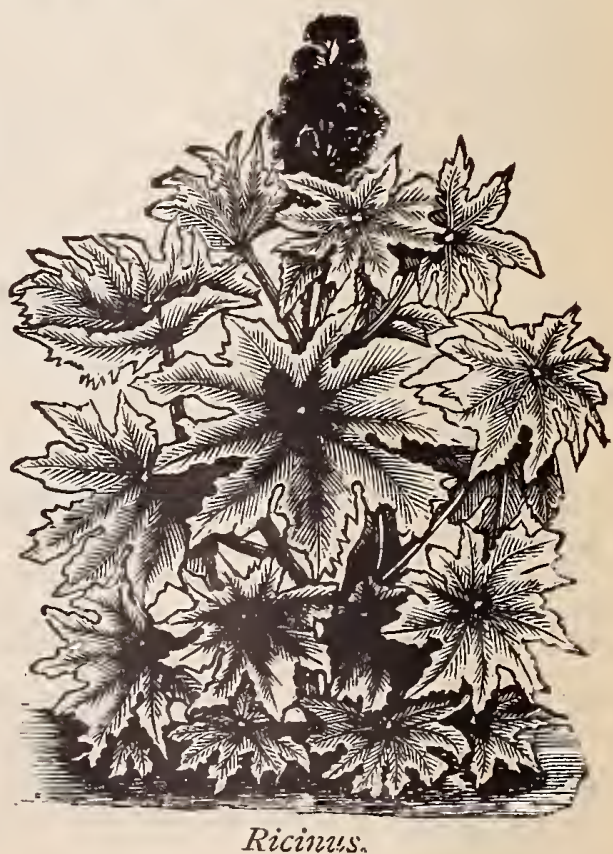




\section{Ornamental Climbers}

Vines are the tapestry of the garden, embroidered with their own blossoms. All the most popular hardy annual and perennia? kinds will be found here; tender sorts, among seeds of Greenhouse Plants.

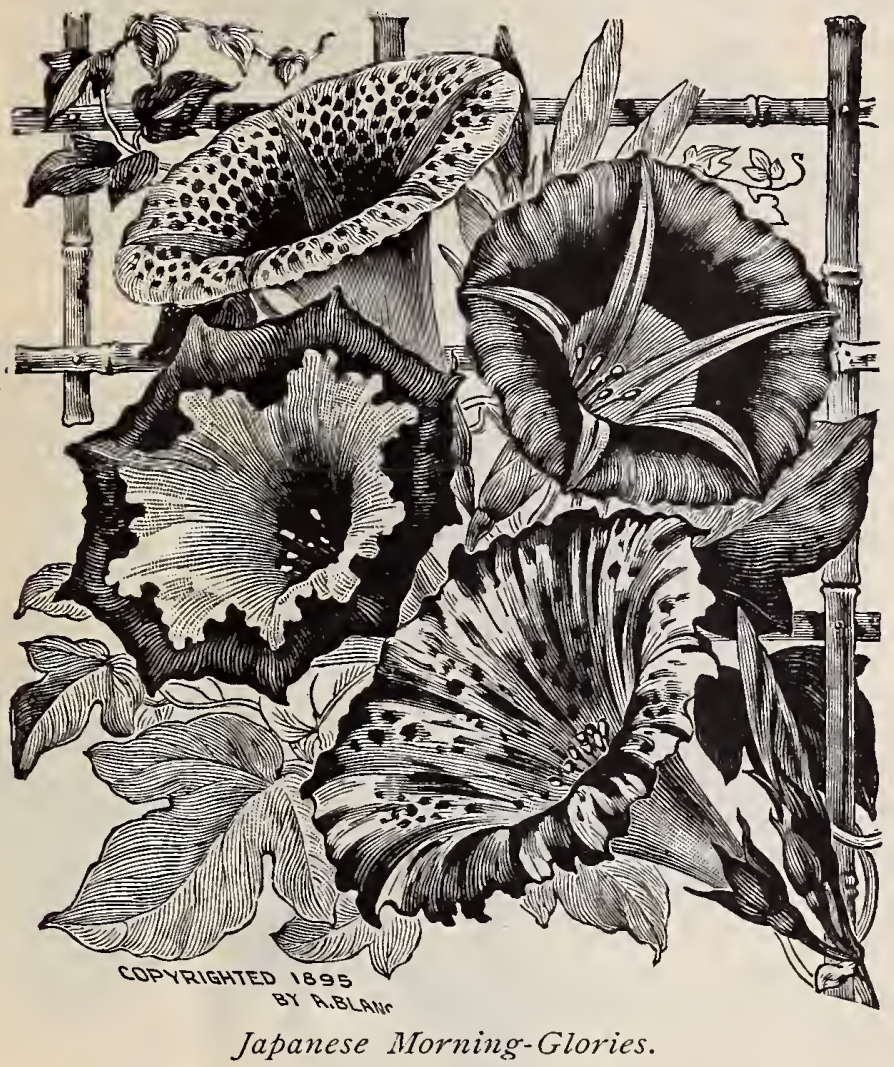

AMPELOPSIS VEITCHII (Japan, or Boston Ivy)

A beautiful vine for covering walls and buildings, to which it adheres closely. The leaves color beautifully in autumn. roc. per pkt.

\section{CENTROSEMA GRANDIFLORA}

Large, pea-shaped flowers, produced in clusters; in color rosy violet, with broad, feathered markings of white. Foliage abundant and graceful. A hardy perennial, climbing 6 to 8 feet in a season, and blooming abundantly. Io cts. per pkt.

\section{COBAEA SCANDENS}

A tender annual of very rapid and luxuriant climbing habit. The deep violet-blue flowers are large and bell-shaped, averaging 2 inches in length and $I \frac{1}{2}$ inches across. Io cts. per pkt.

\section{DOLICHOS LABLAB (Hyacinth Bean)}

Noted for its large clusters of snowy white or purple flowers. It grows rapidly, and makes a fine screen of thick foliage. A tender perennial. 5 cts. per pkt.

\section{HUMULUS JAPONICUS (Japanese Hop)}

Annual climbers of very rapid growth, with dense foliage. The leaves remain bright and fresh and rich looking until late in the fall. Humulus Japonicus. Leaves plain green, something like those of the common hop. Seed sown in early spring produces plants which will cover a wide spread in a short time. 5 cts. per pkt.

H. - variegatus. Leaves broadly edged with cream color, and marked and shaded with silvery white and deep green; often a whole branch and its leaves will be pure white. At a little distance the plant looks as if it were covered thickly with white blossoms. It is very vigorous and hardy. Io cts. per pkt.

LATHYRUS LATIFOLIUS (Everlasting Pea)

Hardy perennial climber, growing 6 to 8 feet high when trained on a trellis. Flowers borne in large clusters. Red and white, mixed, Io cts. per pkt.

\section{MAURANDYA}

Graceful annual climber for window or conservatory; admirable to hang from vases, and to cover stumps and low trellises; blooms very freely. Io cts. per pkt.

\section{Grand "Imperial Japanese"}

\section{MORNING=GLORIES}

These grand climbers have given unbounded satisfaction and surprise at their great beauty and variety. The vines are of strong and robust growth, attaining a height of from 30 to 50 feet. The foliage is most luxuriant, distinct and varied-some vines have rich, vivid green leaves, others have silvery leaves, some with yellow leaves, and many produce leaves mottled and checkered like rich mosaics of light and dark green, white and gray. The intermingling vines and brightly contrasting colored leaves are wonderfully pretty and effective, even when the flowers are not open. But their surpassing charm lies in the entrancing beauty and gigantic size of the flowers; they measure from 4 to 6 inches across, and their greater substance causes them to remain open much longer than ordinary Morning-Glories. The colors of the flowers, shadings and markings are limitless, and are really wonders of nature, of such incomparable beauty that descriptions are inadequate. Some flowers are of deep, rich, velvety tones, others daintily tinted and shaded. The solid colors range through reds from soft rose to crimson, bronze and garnet-maroon; from daintiest light blue to ultramarine, indigo and blackish purple from snow-white to cream and silver gray. Some are striped, starred and spotted, others have magnificent edges and throats. They are of the easiest culture. Sow early in a warm, sunny position in good, rich soil, and give plenty of water in dry weather. Mixed colors, Io cts. per pkt.

\section{CONVOLVULUS MAJOR (Morning=Glory)}

A well-known and favorite annual, rapid in growth and prodigal of bloom.

Splendid Mixture. Will produce flowers of all the best colors. 5 cts. per pkt.

\section{IPOMOEA}

In the large class of tender annuals are included many handsome climbers. Evening- as well as Morning-Glories, and other favorite vines almost as popular and beautiful.

Ipomœa setosa (Brazilian Morning-Glory). Beautiful rose-colored flowers and huge leaves; remarkably luxuriant in growth. Io cts. per pkt.

I. Leari. Flowers violet-blue; an elegant greenhouse species. Io cts. per pkt.

I. quamoclit (Cypress Vine). Delicately cut foliage and small star-shaped flowers of scarlet or white. Mixed, 5 cts. per pkt.

I. grandiflora (Moonflower). The large pure white flowers of this plant open at night; produced in great abundance, and quite fragrant. Io cts. per pkt.

I. Heavenly Blue. Foliage very large and heart-shaped; flowers 4 to 5 inches across, borne in large clusters; light blue, with yellow throats. The bloom also hides the foliage. Ioc. per pkt.

I. Bona Nox (Good-Night, or Evening-Glory). Most beautiful large violet flowers. 5 cts. per pkt.

\section{NASTURTIUMS (TROPAEOLUMS)}

(For Dwarf Varieties, see page 25)

The gay and picturesque Nasturtiums are almost as popular among climbers as sweet peas. Their rapid and luxuriant growth quickly covers trellises, verandas, fences, or any unsightly object, with a beautiful mass of oddly pretty leaves and brilliant flowers. No plant could be freer with its blossoms, or display them in a more graceful way.

Tropæolum majus atropurpureum. Crimson. 5 cts. per pkt., 20 cts. per oz.

T. - Edward Otto. Brownish lilac. 5 cts, per pkt., $20 \mathrm{cts}$ per oz. T. - hemisphericus. Orange. 5 cts. per pkt., $20 \mathrm{cts}$. per $\mathrm{oz}$

T. - Pearl. White. 5 cts. per pkt., 20 cts. per oz.

T. - Rœgelianum. Violet-ruby. 5 cts. per pkt., $20 \mathrm{cts}$. per oz.

T. - Scheurianum. Pale yellow spotted. 5c. per pkt., 20c. per oz.

T. - Schillingil. Spotted. 5 cts. per pkt., 20 cts. per oz.

T. - Von Moltke. Ruby-rose. 5 cts. per pkt., 20 cts. per oz.

T. - Yellow. 5 cts. per pkt., 20 cts. per oz.

T. - Finest Mixed. Seed saved from a choice collection of flowers, in many colors: will produce charming results if planted freely in grcund that is not too rich. 5 cts. per pkt., Io cts. per oz.

T. - peregrinum (Canary Creeper). Graceful, winged flowers of pure light yellow. $5 \mathrm{cts}$. per pkt., $20 \mathrm{cts}$. per oz.

T. - Lobbianum. Very superior for trellises, arbors or vases: flowers very brilliant and rich, borne profusely. Mixed colors, 5 cts. per pkt., 25 cts. per oz. 


\section{SWEET PEAS}

Fashion does not always display so much good taste in her choice of a "pet flower" as when giving the Siveet Pea that place. Already" they have become so popular that seedsmen must handle their seeds by the ton, and they are grown galore in hedges, sold in great fragrant heaps from the markets, and worn and carried whenever and wherever possible. Every garden must hare its hedge of Sweet Peas, and we are ready to supply you with the best of seed.

All the following varieties, 5 cts. per pkt.

America. The brightest blood-red striped. ro cts. per oz.

Apple Blossom. Soft rose, on silvery white. Io cts. per oz.

Black Knight. Rich wine brown, shaded with dark purple. per oz.

Blanche Ferry. Pink and white. Io cts. peroz.

Boreatton. Crimson-purple, very dark. Io cts. peroz.

Countess. Clear lavender. Io cts. per oz.

Eliza Eckford. White, shaded rosy pink. Io cts. per oz.

Emily Henderson. IVhite, early. Io cts per oz.

Fascination. Very large flowers, deep rosy lavender. Io cts. per oz.

Firefly. The farorite bright scarlet variety. Io cts. per oz.

Lady Mary Currie. Pink, shaded rosy lilac. Io cts. per oz.

Lottie Eckford. White and lavender. Io cts. per oz.

Maid of Honor. White, edged violet Io cts. per oz.

Mrs. Dugdale. Light carmine rose, with faint markings of primrose. Io cts per oz.

Mrs. Eckford. Delicate primrose-yellow. Io cts. per oz.

Navy Blue. Deep violet-blue Io cts per oz.

Queen Victorla. Pale yellow. Io cts. per oz.

Sadie Burpee. Pure snowy white, very large flowers. Io cts. peroz.

Salopian. Best of all reds. Io cts. per oz.

Eckford Mixture. Large-flowering; all colors. Io cts. per oz., 20 cts. per $1 / 1 \mathrm{lb}$., 60 cts. per $1 \mathrm{~b}$.

Fine Mixed. Light colors predominating. Io cts. per oz., $20 \mathrm{cts}$. per $1 / \mathrm{lb}$., 50 cts. per lb.

Finest Mixed. Our own mixture of the largest flowering sorts. Io cts. per $0 z$., 25 cts. per $1 / 41 \mathrm{~b}$., 75 cts. per $1 \mathrm{~b}$.

\section{THUNBERGIAS}

These are among our best half-hardy annual climbers. The vine is of slender and graceful but very rapid growth, with elegant foliage and extremely pretty, dark-eyed flowers of white or yellow.

Thunbergia alata. Flowers buff, with dark center; very bright and pretty. 5 cts. per pkt

T. - alba. White flowers, with black eye; of excellent effect. 5 cts. per pkt.

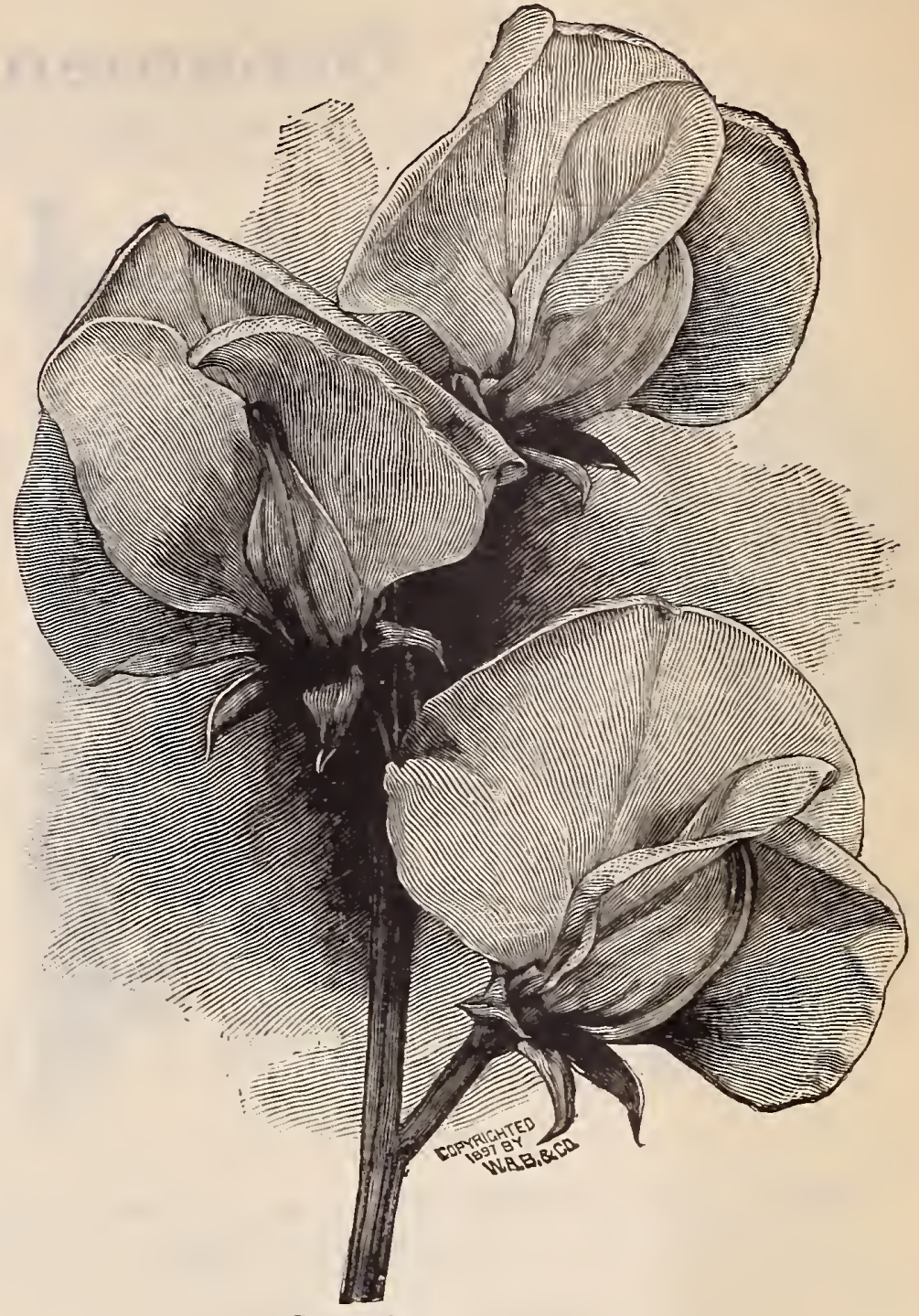

Sweet Peas.

\section{Insecticides}

Intelligent farmers and gardeners now fully recognize the great helpfulness of insecticides in fighting the enemies which are so destructive to all sorts of crops. Such remedies are all the more effective if applied early, before the insects, etc, have greatly increased.

Fir-Tree Oil. Destroys insects without injuring the plants. Dilute in the proportion of I pint to 20 gallons of water

Hellebore, White, Powdered. An excellent protection from currant worms, grape slugs, etc. May be applied dry by dusting on with a bellows, or as a liquid, mixed at the rate of 1 pound to 30 gallons of water.

Parls Creen, Pure. Nixed at the rate of I pound to Ioo gallons of water, it will prove effective against all chewing insects.

Little's Antipest. A sure destroyer of all insect pests. It is non-poisonous and harmless to regetation. Mixed with water in the following proportions, it is effectual against pests; greenfly, I pint to Io gallons of water; mealy bug, I pint to $1 \frac{1}{2}$ gallons; red spider, I pint to 2 gallons; ants, wire-worms and slugs, I pint to I gallon.

\begin{tabular}{c}
\hline "ApнIa вRANd" \\
Tobacco-Whale Oil \\
SOap. \\
we kxow ITs Goodness \\
\hline
\end{tabular}

Slug Shot, Hammond's. Excellent for destroying cabbage, turnip and beet flies, potato bugs, currant worms, etc.

Tobacco Whale-Oil Soap. Effective for scale, green and black flies, mealy bug and red spider in greenhouses, hen lice, dog fleas.

Tobacco Dust. If dusted on while the foliage is moist it destroys rose lice, cabbage and turnip fleas, etc. Spread upon the ground, it keeps off all earth insects, and is an excellent fertilizer.

Tobacco Stems. For fumigating plants infested with greenfly, etc.

Nikoteen Aphis Punk. A preparation of Nicotine in most convenient form for killing insect life on plants and flowers, without injuring the most sensitive bloom or foliage.

Ant Exterminator. For the destruction of ants in lawn and pleasure grounds. Directions for use on each package.
Whale-Oil Soap. For washing trees and destroying all insects on the bark. Mixed at the rate of I pound 104 gallons of water, it will rid cabbage, rose bushes, peach trees, etc., of the aphides that so often infest them.

Bordeaux Mixture. For all fungoid diseases, such as mildew and the various rots of the grape. It is prepared as follows: Dissolve 6 pounds sulphite of copper (blue vitriol) in 6 gallons of hot water ; in another vessel slake 4 pounds of fresh lime in 6 gallons of cold water. When both are cool. pour the two mixtures together and add ro gallons of water. This, then, when all is thoroughly mixed, is ready for use, and may be applied at any time without injury to the foliage. We can furnish this all mixed at the small cost of 2 cents per gallon

Sheep Dip. For sheep, horses and cattle.

Leggett's Fungiroid. A powdered Bordeaux Mixture. Is applied when the foliage is wet with rain or dew.

Ammoniated Copper Solution. IVill save your melon vines. Not only prevents blight, but will check it after it has developed.

Flowers of Sulphur. For prevention and destruction of mildew on plants.

Leonard's Household Disinfectant (King of the Air). Removes all foul odors, is clean and agreeable to handle: used extensivelv everywhere. No market, hotel, etc., or even family, should be without it.

Morrill's Canker Worm Exterminator. One of the best and cheapest remedies for the protection of trees from the ravages of the grub or canker worm. Directions with each can.

Kerosene Emulsion, Concentrated (Lion Brand). One of the best all-round insecticides. Especially valuable for the destruction of the green and the black fly, scale, woolly aphis, curculio and all sucking insects. 


\section{Essex High Grade Fertilizers}

The Essex Fertilizers are high grade in every respect. They are made from the best raw materials that can be obtained, and in a modern factory fully equipped for producing goods in the very finest mechanical condition.

They are prepared with special reference to the needs of the soils and crops, and under the supervision of men who keep in close touch with the best work of practical farmers, as well as with the results at the Experiment Stations.

\section{ESSEX ODORLESS LAWN DRESSING}

A superior article of top-dressing for lawns. It is prepared entirely from chemicals, has little or no odor, contains no seeds or litter, is easily applied, and is very soluble and quick-acting. It produces a vigorous growth of grass, and, if properly cared for, lawns on which it is used will retain a rich dark green color through all the heat of summer. Put up in 25-, 50- and Ioo-pound packages for the convenience of the trade.

\section{DARLING'S FERTILIZERS}

Darling's Animal Fertillzer. Contains a very large percentage of ammonia, phosphoric acid and potash. As a general Fertilizer for all crops, it is the best. We have sold it for 20 years, and the increased demand each year speaks volumes for its value.

Potato and Root Crop Manure. This is one of the best Fertilizers for potatoes ever sold. It contains a very high percentage of potash and phosphoric acid, and produces a smooth, desirableshaped potato. The potash in this brand is entirely from sulphate of potash; the phosphoric acid is from bone.

Darling's Pure Fine Bone. Contains from 25 to 28 per cent of pure phosphoric acid, and 3 to 4 per cent ammonia. Is the very best material from which phosphoric acid can be obtained.

Darling's Lawn Dressing. There is a call at the present time for a commercial Fertilizer to be used on the lawn. Stable manure is objectionable, as it is bulky, containing a large amount of refuse material. It also contains the seeds of many weeds and obnoxious grasses that are difficult to root out when once they have gained a foothold. By the use of this Fertilizer all these objections are removed. It will produce an excellent growth of rich green grass.

Canada Unleached Hardwood Ashes. As a Fertilizer for la wns and gardens, Hardwood Ashes are unequaled; they supply natural plant-food, permanently enriching the soil. One of the best for lawns, giving the grass a rich, dark shade of green, and destroy-

ing many of the insects which are so injurious to grass, roots and eaves.

Pulverlzed Sheep Manure. A soluble plant-food, highly recommended for all purposes where a first-class Fertilizer is required. It is a pure natural manure, and has long been recognized as one of the most beneficial. As a top-dressing for lawns it is unequaled being free from weed seeds and exceedingly stimulating. For lawns, it should be used at the rate of 500 pounds per acre. As a fertilizing agent for plants indoors, and in the open garden, it is one of the very best.

Land Plaster, or Gypsum. This is an excellent addition to land for such crops as require lime and sulphates, particularly turnips, potatoes, grasses, etc.

Sulphate of Ammonla, Dissolved Bone-black, German Potash Salts, Sulphate of Potash, Nitrate of Soda, Plain Disolved Bone, Murlate of Potash, Sulphate of Potash (High Grade). We can furnish these materials, either separate or mixed, in any proportion, or to conform to any formula.

Bowker's Ammoniated Food for Flowers. Made expressly for flowers grown in the house or garden; clean, odorless and produces early, abundant blossoms, greatly adding to the richness and brilliancy of color, health and luxuriant foliage. It is clean and absolutely odorless.

\section{Nitro=Culture}

\section{DOUBLES YOUR CROP. NO TIME. NO LABOR. LITTLE EXPENSE}

Nitro-Culture is a germ, sold in dry packages like a yeast cake. (Dissolve in water as per directions which come with each package.) When seeds are sprinkled with the solution before planting, the germs multiply in the soil very rapidly, and cause nodules to form on the roots of plants. These nodules collect the nitrogen out of the air and feed the plant-roots.

WHAT IS CLAIMED FOR NITRO-CULTURE.-On poor or sandy soil, any leguminous (i. e., pod-bearing) crop, such as clover, alfalfa, beans, peas, vetch, peanuts, etc., can (provided good seed is used) be more than doubled the first year, by merely moistening the seed with a solution of Nitro-Culture bacteria and allowing it to dry on the seeds before planting. Perhaps the greatest benefit may be derived the second year, when any crop, such as wheat, corn, cotton, potatoes, etc. may be planted without fertilizer, and they will yield double what would otherwise be taken from the same land. Many persons claim that in money value this would be equal to $\$ 20$ per acre, or that a like amount would have to be expended on phosphates, capable of producing equal results. Can you afford to overlook this cheap but effective method which nature has provided for the enrichment of the soil?

\section{PRICE - LIST}

Nitro-Culture, sufficient to inoculate tle following seeds per acre, mailed to any address in the United States or Canada at the following prices:

Alfalfa................................ $\$ 2$ oo

Red Clover............. " 200

Crimson Clover........... " " 200

Cow-peas .............. " 200

200

IVax Beans.............. per acre, $\$ 2$ oo

Garden Peas............ I/2 acre, I oo

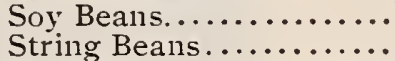

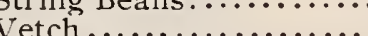

Lima Beans..............

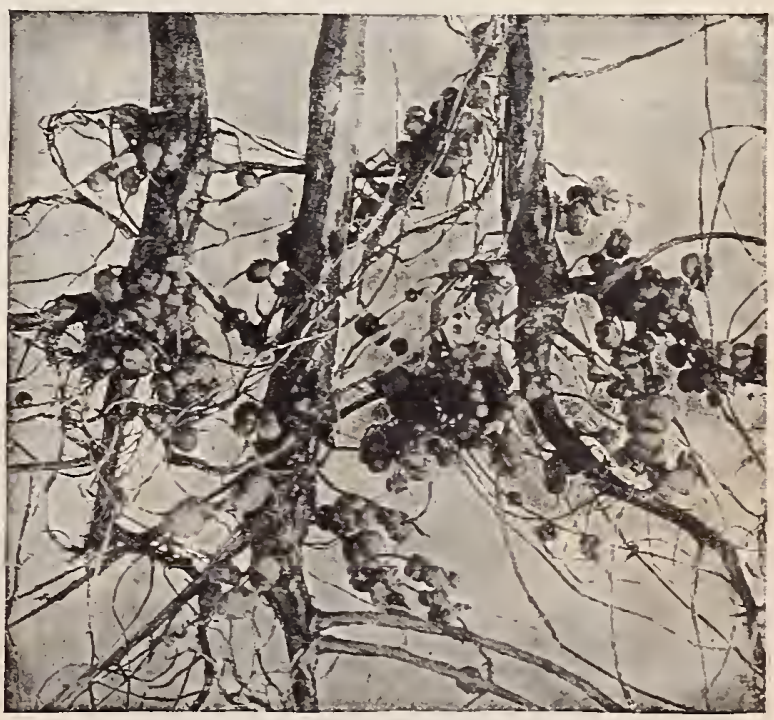

Roots of Soy Bean:. showing the nodules which collect the free nitrogen from the air and deposit it in the soil, thus making barren land productive, and after the first crop is harvested the ground is left richer and better for the is harvested the
next year's crop plant food.

Descriptive circular treating more fully on the matter, free upon application 


\section{Garden Requisites, Etc.}

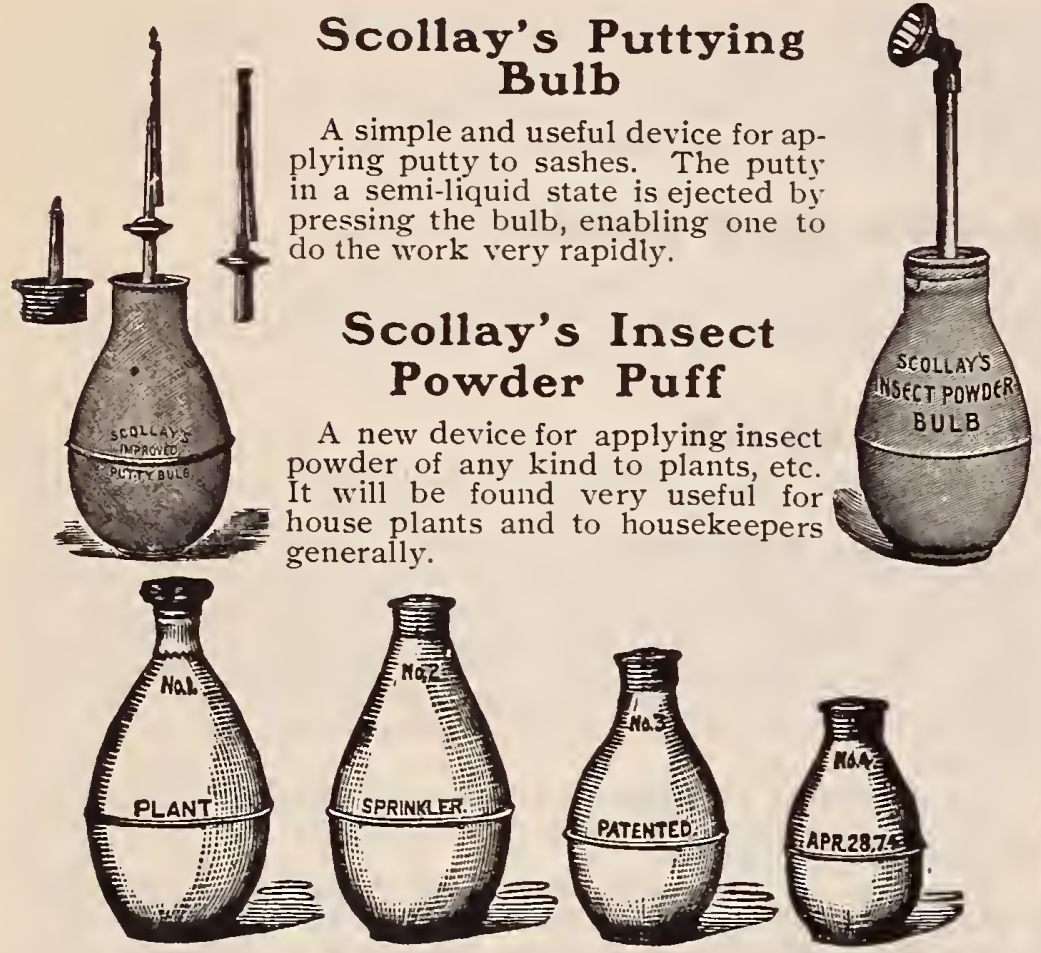

Scollay's Rubber Plant Sprinkler

Made of rubber with flat bottom and a finely perforated detach able brass top. Very useful in bouquet making and window gardening, for sprinkling and for all purposes where a fine spray is required. Four sizes.

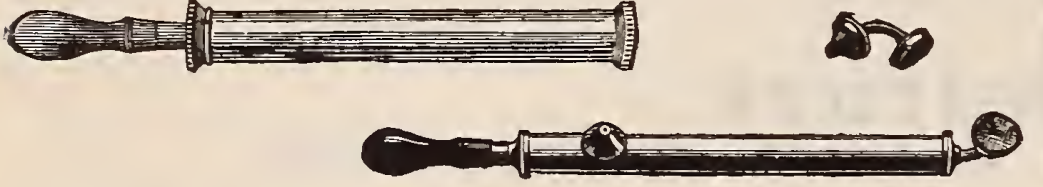

\section{Brass Greenhouse and Garden Syringes}

These Syringes are useful for all horticultural purposes, and are fitted with caps or roses for ejecting water in one stream, for dispersing it in the most gentle manner, or with great force when required. They are especially adapted for whale-oil soap, tobacco juice, etc., in cleaning plants and flowers from those destructive insects which are so injurious to them. Very strongly made of best quality of brass, finely polished, elegant in appearance, not liable to dent or become injured, and if properly cared for will last a lifetime.

\section{Standard Flower Pots}

Measurement from inside to inside. Width and Depth Special prices on large quantities.

\begin{tabular}{|c|c|c|c|c|c|c|}
\hline 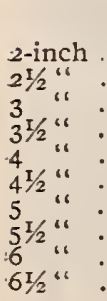 & 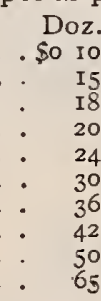 & $\begin{array}{rl}100 \\
\$ 0 & 65 \\
85 \\
1 & 00 \\
1 & 25 \\
1 & 50 \\
2 & 00 \\
2 & 25 \\
3 & 00 \\
3 & 50 \\
4 & 50\end{array}$ & 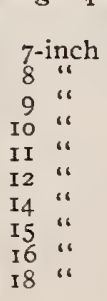 & 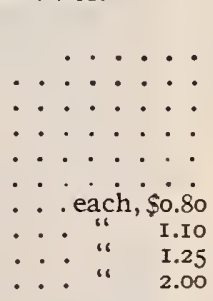 & 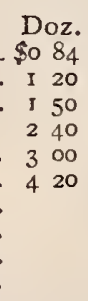 & $\begin{array}{l}100 \\
\$ 600 \\
800 \\
1100 \\
1500 \\
2000 \\
3000\end{array}$ \\
\hline
\end{tabular}

\section{Flower Pot Saucers}

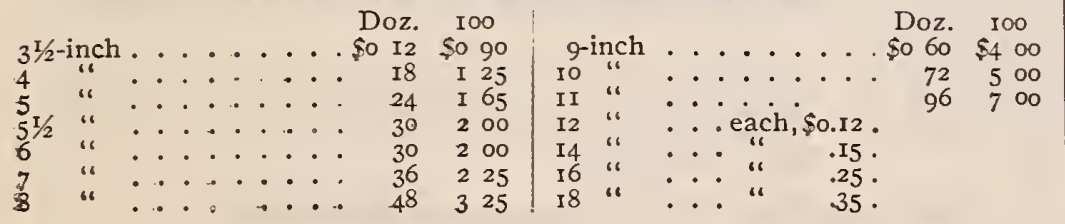

\section{Tin=F oil}

We have on hand a large supply of this. We sell at low prices in any quantity to suit the purchaser.

\section{Labels (Wood) for Plants, Trees, Etc.}
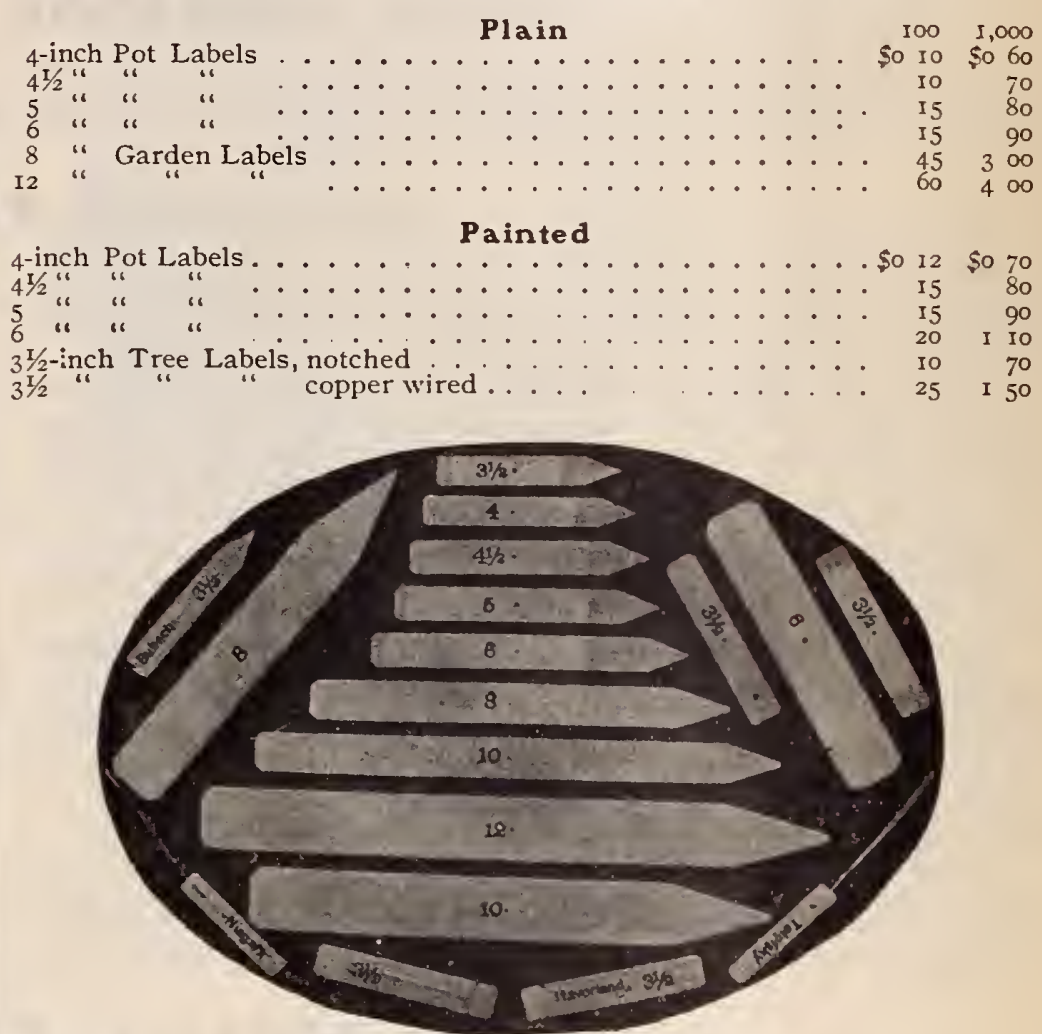

Plant Stakes-Round, Tapering, Painted Green

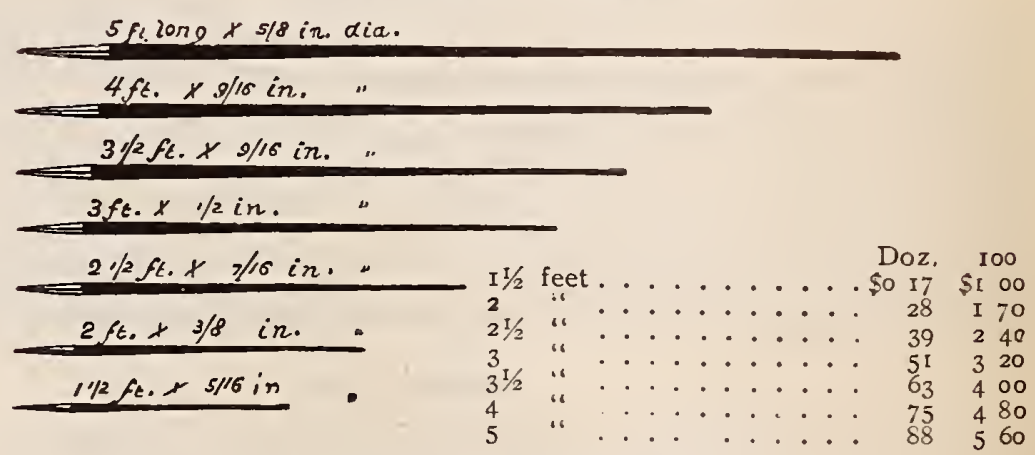

Heavy, Green Painted, Round

Suitable for Dahlias, Hollyhocks, and all plants requiring strong support. 3 feet long $\ldots \ldots \ldots$ Doz.
4 "

\section{Neponset Paper Flower Pots}

Are manufactured of water-proof paper, unbreakable, handsome, light and cheap. They are made so as to admit plenty of air to the roots and to give sufficient drainage. Not less than I,000 at $I, 000$ rate.

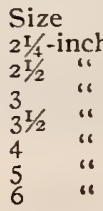

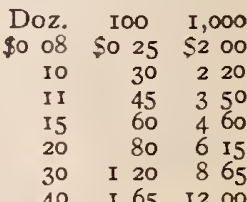




\section{The Townsend Triple Rachet Horse Lawn=Mower}

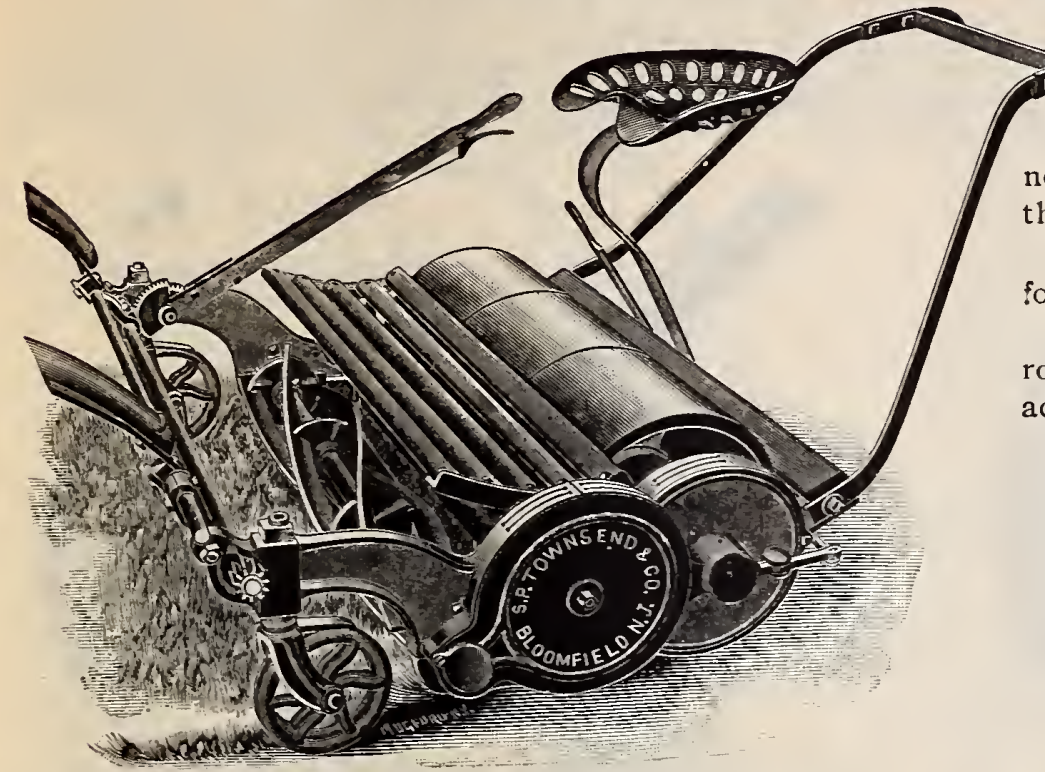

TRIPLE ROLLS, with triple pawls in each roll, making the most powerful driving mechanism ever put in a LawnNower. A lever beside the driver enables him to cut any height from the ground. A slight movement of a small lever near the driver throws the Mower in or out of gear without stopping the horse.

Self-aligning JOURNAL BOXES. A very valuable improvement, found in no other Mower. They prevent cramping of the journals.

It will cut over very rough and uneven ground, and stand very rough usage, and still cut its swath clean and smooth. It is on this account very popular with goif clubs.

Made in 30- and 38-inch width of cut

Townsend Triple Rachet Horse Lawn-Mower.

\section{Townsend "Victory" Lawn=Mower}

It has BALL BEARINGs of the very highest grade, exact to one-thousandth part of an inch, which reduce the friction astonishingly. A 2 t-inch Nower can now be operated as easily as the old parallel-bearing Mower only 16 inches wide.

TRIPLE GEAR, entirely enclosed, prevents dirt and cut grass from clogging.

A SOLID RECTANGULAR FRAME, that cannot be twisted or jarred out of parallel.

DOUBLE STEEL RACHETS, like lightning in action, cause the knives to cut the instant you move the Mower. Io-inch wheels, 4-bladed reel.

SIZES - I4-in., I6-in., 18-in., 20-in.,

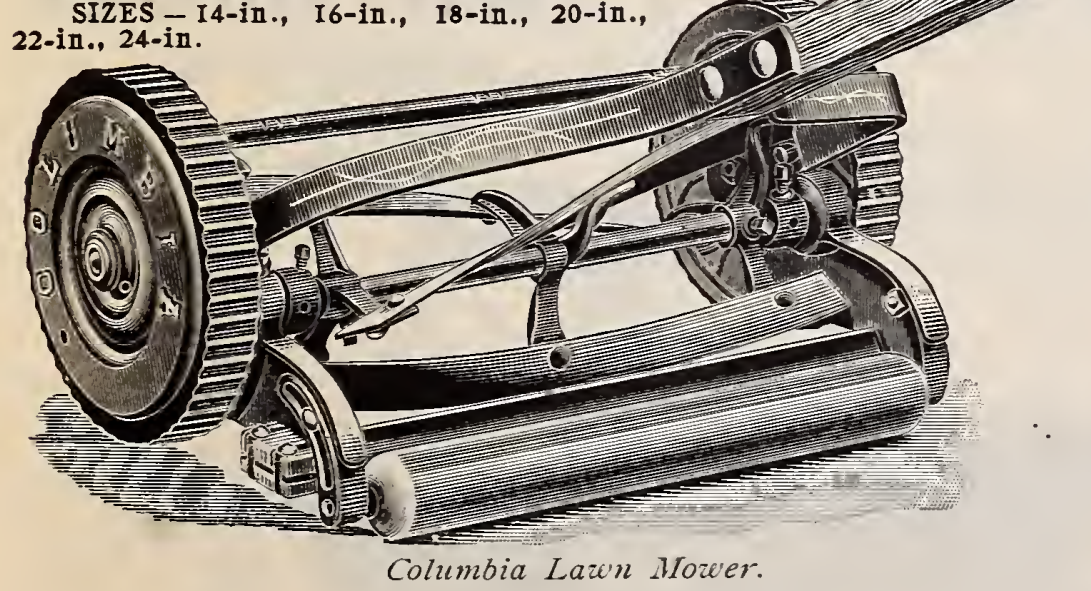

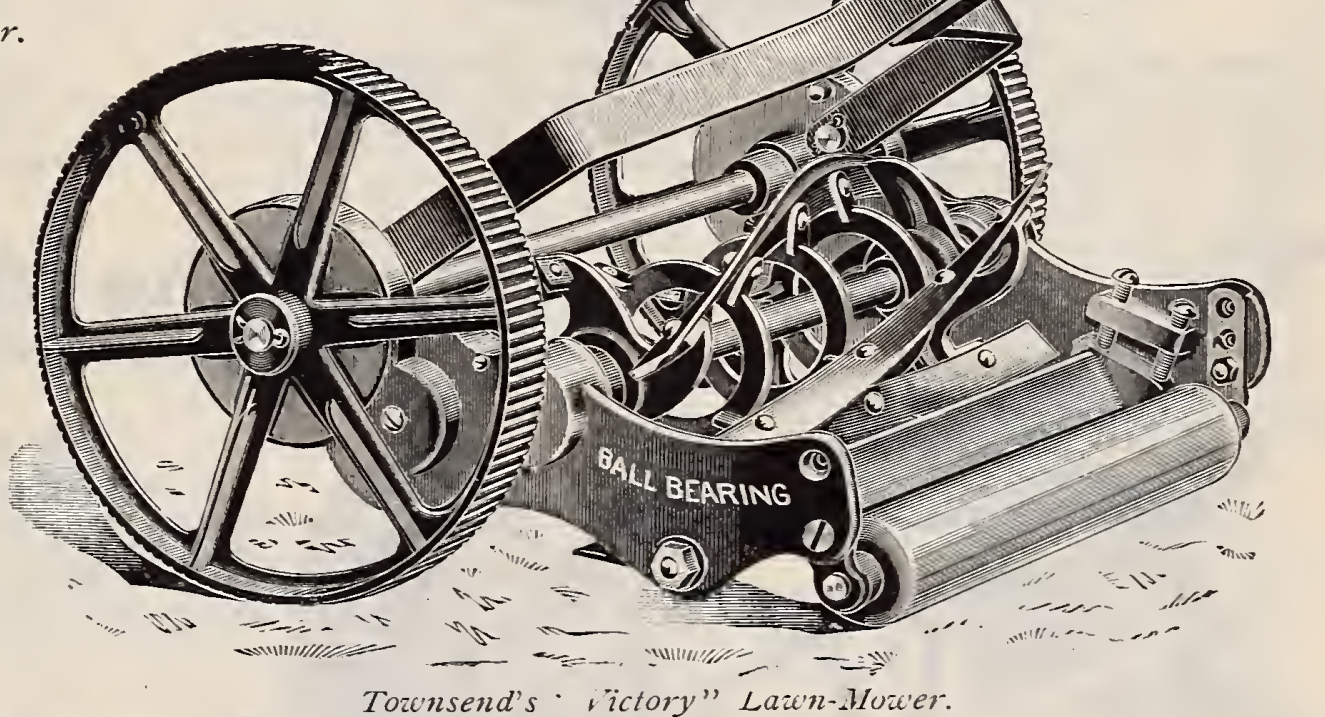

\section{Columbia Lawn=Mower}

THE BEST LOW-PRICED MOWER ON THE MARKET

The Columbia has an 8-inch wheel and a 6-inch reel or wiper. The frame is fastened together by $5 / 8$-inch cold rolled steel shaft, secured to the disks above the reel shafts with case-hardened set-screws. The cutter bar is securely bolted to the disks below the reel shaft, thus ensuring a perfectly strong and rigid machine, which can be easily, quickly and accurately adjusted. The reel shaft is $5 / 8$ cold rolled steel, and runs in long polished brass boxes adjusted by a single set-screw, secured by a lock-nut. The Mower is fitted with a heavy mortised handle, secured to the handle braces by two bolts.

\section{Palmer's Hotbed Mats}

WOOL-FILLED, FROST-PROOF, INDESTRUCTIBLE, CHEAP, WARM

Made expressly for winter covering of hotbeds, coldframes, plants and seeds of all kinds. Will not harbor mice or vermin. Easily handled. Dry out quickly after rain. Have now been in practical use four years. Cost less than old-fashioned straw mats and entirely take their place.

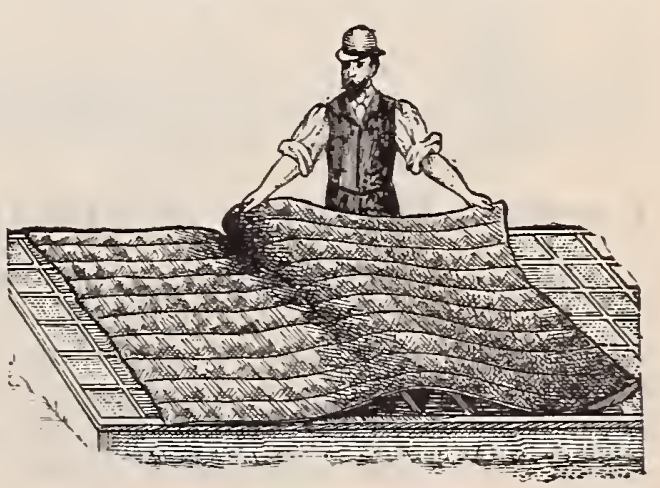

Palmer's Hotbed Mats. 


\section{The Philadelphia Lawn=Mowers}

We desire to call the special attention of the trade to "The Original Philadelphia Lawn Mower." Recently a number of Mowers in imitation of "The Philadelphia" have been put on the market, and, while inferior in, every respect, liave the same general appearance. The genuine Philadelphia still leads the market. Leads in every good improvement. Best known. Most simple and durable. Self-sharpening and easiest kept in order. Don't buy worthless imitations. Prices greatly reduced for 1905.

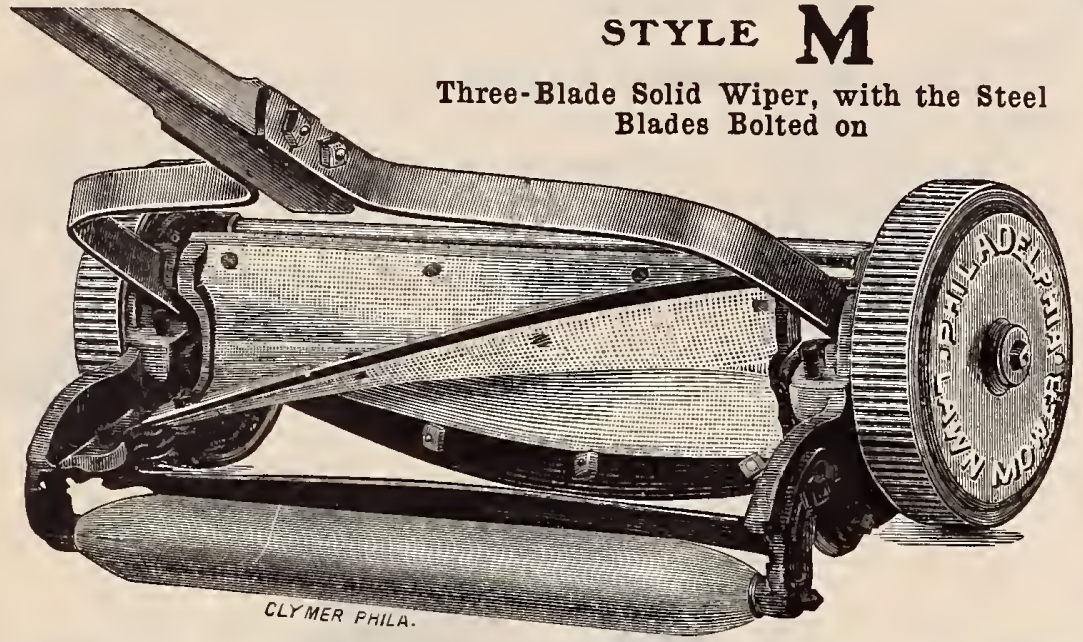

APPROVED BY THE HIGHEST GOVERNMENT AUTHORITIES

This is one of the Standard Mowers, and we know it will please you. This Mower is for general purposes very popular, and adapted for rough and uneven grounds, as well as the finest smooth lawns.

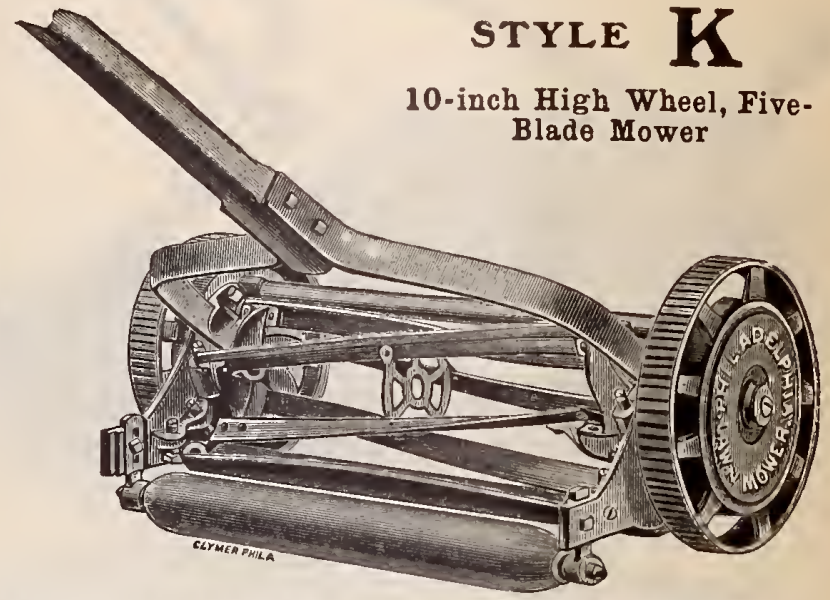

BUY THE GENUINE PHILADELPHIA STYLE $\mathrm{K}$; IT WILL PLEASE YOU

This Mower is made on correct principles with a single pinion and five blades. It does the finest kind of work, and is the lightest-running Mower made. For a first-class Mower it has no equal.

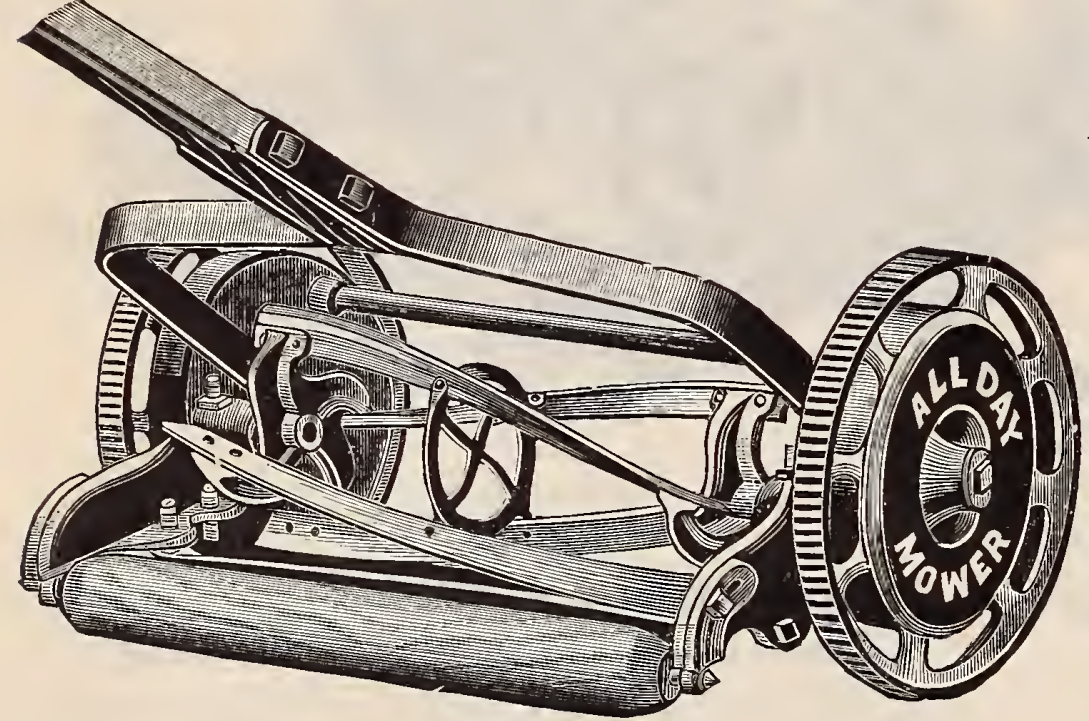

The All Day Mower.

\section{The All Day Mowers}

With 10-inch Wheel, Four-Blade Cylinder, Securely Incased Gears Noiseless Ratchet

THE MOWER GEARED ON BOTH SIDES

No pains have been spared to make this the superior of all others of its class. It is mechanically proportioned so as to run light and do fine work-unlike the three blade Mowers that the market is flooded witl. This is by far the best medium-priced Mower on the market to-day. We have seen it tried under all conditions and the results have been very satisfactory.

\section{Genuine Philadelphia Horse Lawn=Mower}

THE BEST HORSE LAWN-MOWER MADE

It has a wrought-iron frame and castor roller attachment which can be raised or lowered at the will of driver, with the machine in motion. The spiral blades are bolted on the cylinder frame and adjusted by set screws. No other machine has this manner of adjusting spiral knives. Furnished with seat and shafts and sidedraft attachment. This Mower is standard the world over, being used on all Government Grounds, Public Parks and Lawns in the country.

It is constructed in the most thorough manner, with steel shaftings, brass bushings, etc., and while it costs more money, is the cheapest Mower on our list when durability, construction and cost are taken into consideration. This Mwer will give you best results, and satisfaction is guaranteed.

\section{Lawn = Mower Repairs}

We have the repairs for the Lawn-Mowers we sell. No waiting two or three weeks, or sometimes not getting them at all, like hundreds of cases that come to us every year. Remember, that for the Mowers we sell you can get your repairs, and get them at once.

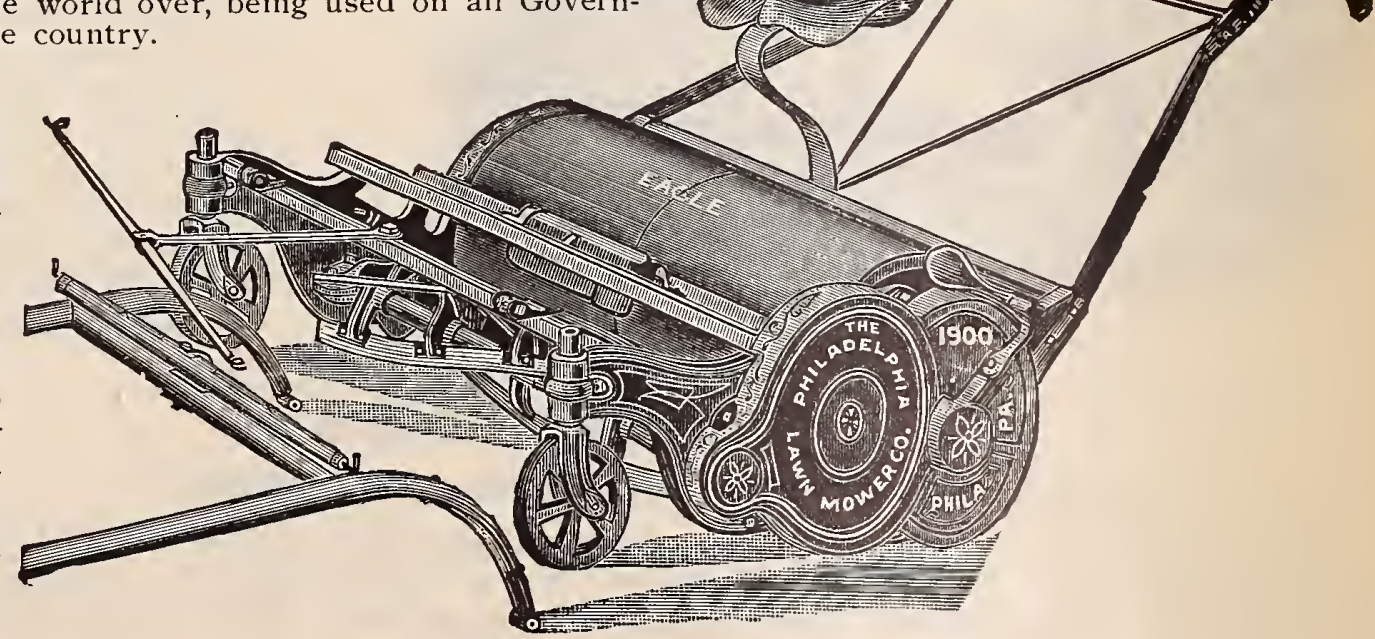

Philadelphia Horse Lawn-Mower. 


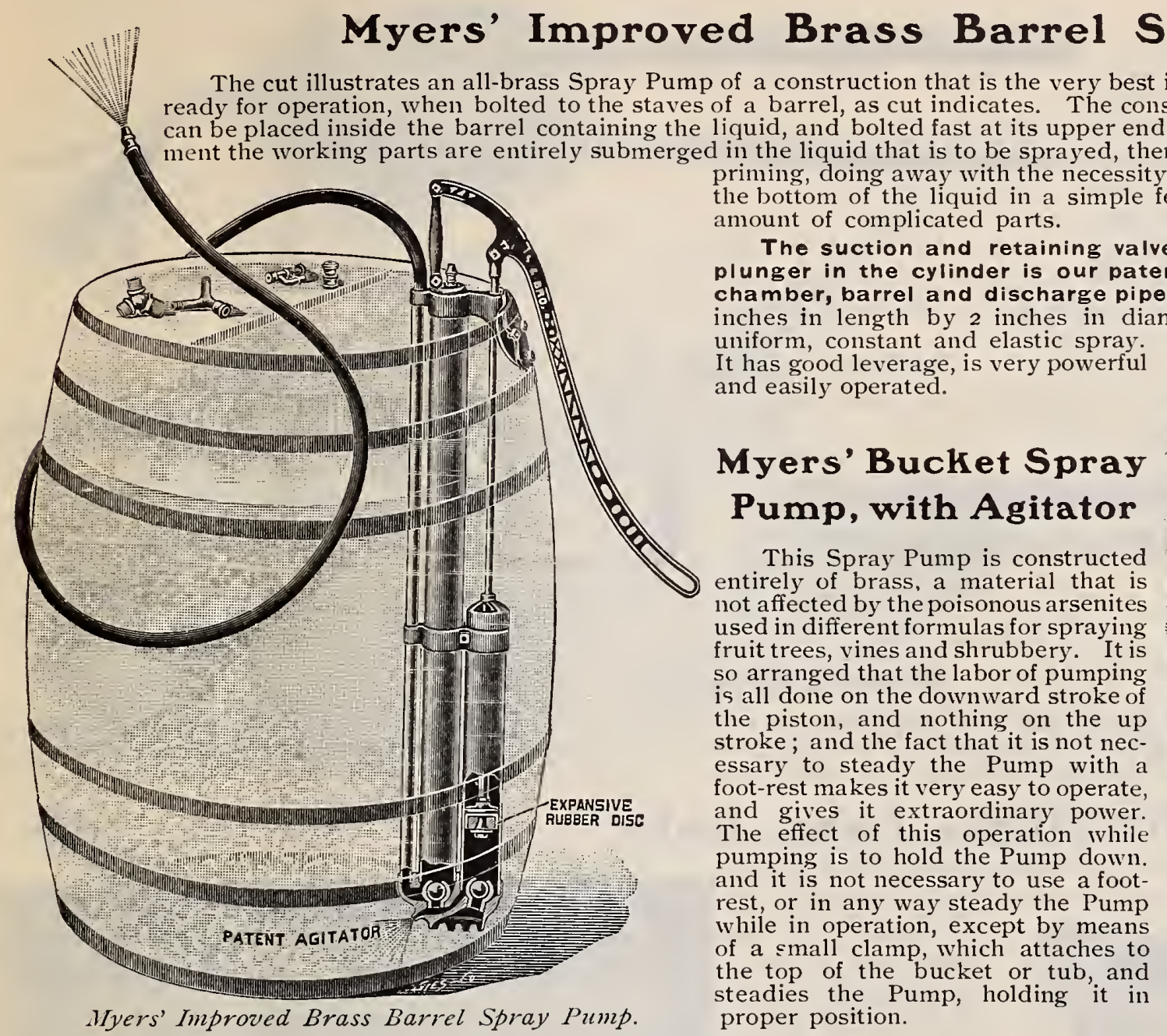

\section{Spray Pump} he construction is such that the entire Pump can be placed inside the barrel containing the liquid, and bolted fast at its upper end to the barrel staves. By this arrangepossibilities of losing 


\section{Acme Powder Gun}

A simple, practical implement for the extermination of potato bugs and all kinds of insects, flies, etc., the pests of every house and garden. It will handle all insecticides in their dry state-pure Paris green, helle bore, Persian insect pollder, etc. It is very effective in the destruction of potato bugs currant worms, and all like pest., and for the wholesale destruction of house flies, using freshly ground Persian insect powder, cannot be excelled. Both gardener and housekeeper, having once tried it, will bless the day on which this little implement was brought to their notice.

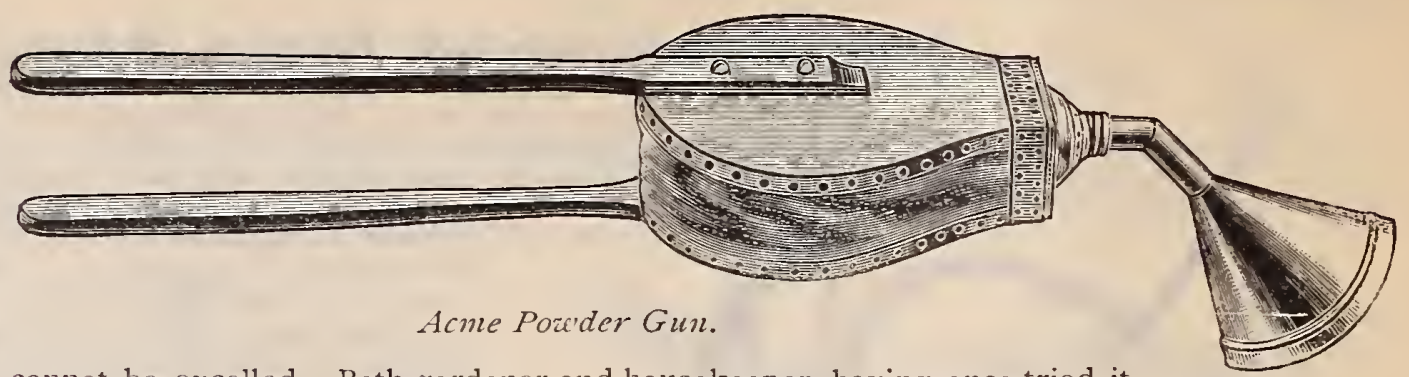

\section{Acme Sprayer}

This Sprayer is adapted for every kind of insect killing and spraying purposes. There is no insect living that this machine will not kill when the right ingredients are used. It is a great saving of labor, and also a great saving of liquids, as the spray is as fine as mist,

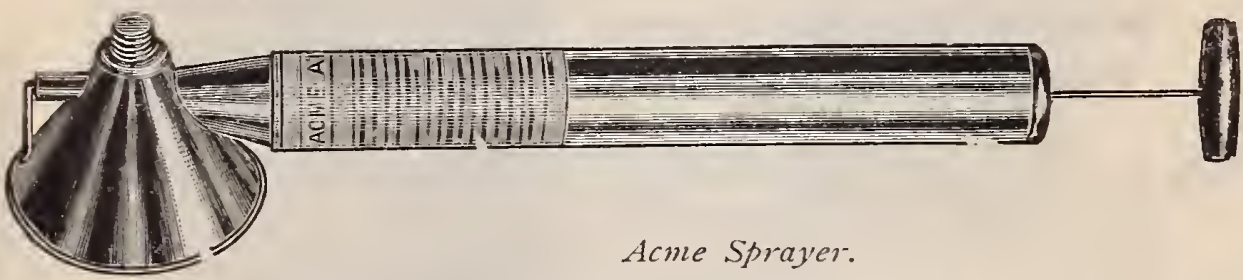
and adheres to the plant. It is highly recommended by florists and gardeners, as well as by every lady who has used it for house plants. Also, by stock-raisers, for keeping flies from cattle and horses during the summer montlis. Fine, also, for killing plant-lice, fleabeetles, aphides, green-fly, mealy bugs, etc., such as attack cabbaye, melons, squashes, cucumbers, plum trees and small fruits of all kinds. Use kerosene emulsion. It is safe and very effective.

\section{Wheelibarrows}

There is no article that has such general and hard usage as the IVheelbarrow; consequently it is of the utmost importance to have only the best, as in the long run they prove the cheapest. Our Barrows are made of carefully selected hard woods, strongly braced and thoroughly ironed throughout. We offer these Barrows in four sizes, each of which will be found perfectly adapted to the use for which it was intended.

\section{The Gibbs Lawn $=$ Rake}

Reversible; all steel; heavily tinned; best that is made. Head is of No. 16 fine cold rolled steel bent in the stiffest form, in which the teeth are

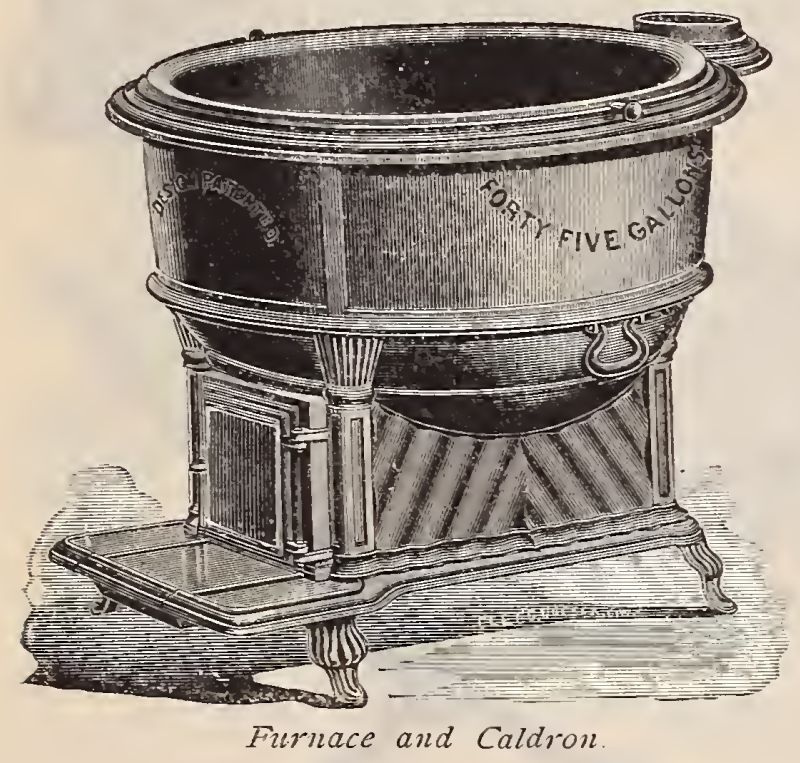
securely held. Socket is firmly secured without rivets or weld, guaranteed to be secure. Handles of ash, finely polished. The Rake runs smooth; its teeth will not tear the sod or clog with grass or leaves.

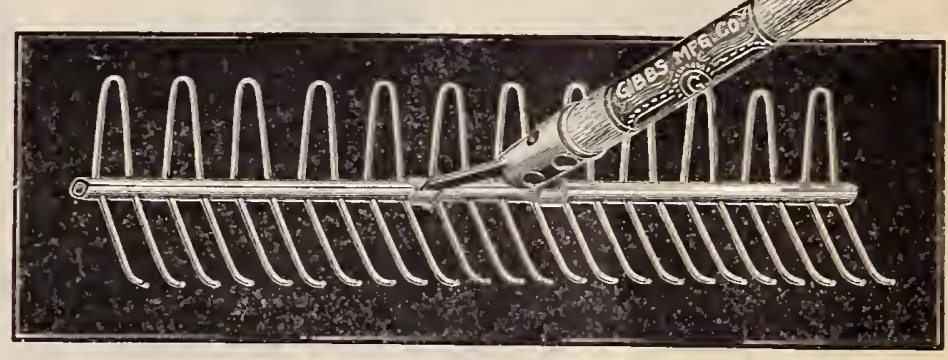

The Gibbs Lawn-Rake.

\section{Furnace and Caldron}

Our Furnaces and Caldrons are made in seven sizes, for hard or soft coal or wood. The flues are so constructed that the heat is directed against the whole surface of the Caldron at the same time and none wasted. The Furnaces are set on legs and provided with handles, so they can be set anywhere, outof-doors as well as inside, and fitted with smoke-pipe and are instantly ready for use. It is of suitable length for wood and for coal, is provided with coal grate and heavy substantial brick.

These Furnaces and Caldrons are used by butchers, farmers, cheese makers, stock raisers, hotel keepers, bakers, brewers, chemists, druggists, dyers, painters, laundries, chandlers, and for various other agricultural and manufacturing purposes.

\section{Steel Land Rollers}

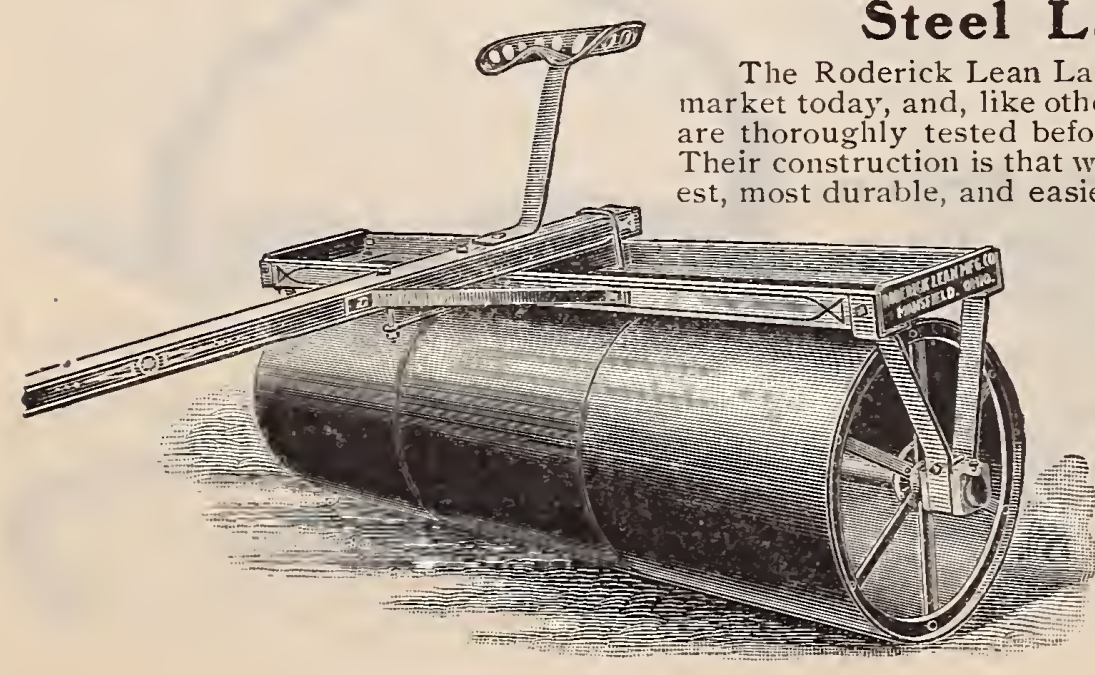

Roderick Lean Horse Roller.

Superior Steel Lawn Rollers

The sections are made of smooth rolled steel without projection or rough ness of any kind to gather soil or grass. The handles stand erect automatically. The rims are cushioned to prevent breakage and deaden the disagreeable noise common to ordinary Rollers when in use.
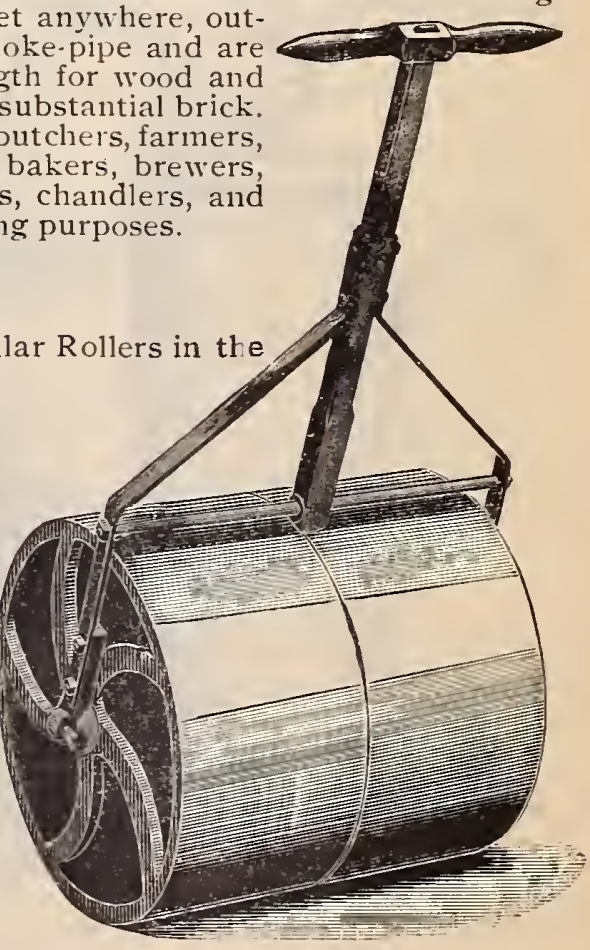

Hand Roller. 


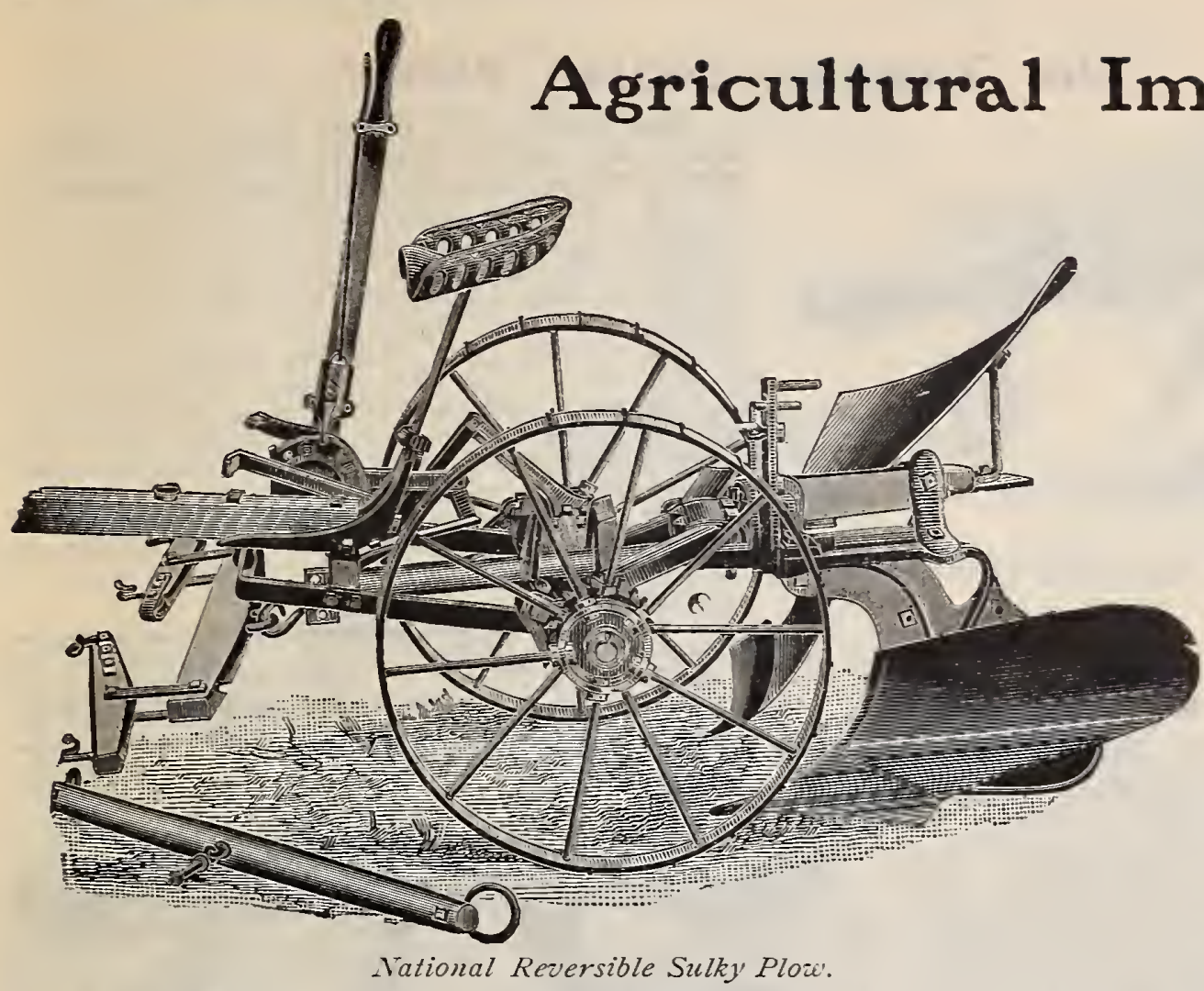

\section{National Reversible Sulky Plow}

Tillers of the soil have long felt the pressing need of a Reversible Sulky Plow that would do perfect work on both level and side-hill land, but such a thing heretofore has seemed among the impossibilities. In their construction are used $T$ wo Perfect Steel Flat-Land Plows mounted upon a Steel Beam. When one is in use the other hangs at right angles abore it, and greatly assists in preventing the plow from tipping on steep, hillside land.

The Sulky is made so as to use two or three horses. Plows are raised out of the ground by one of the most perfect power lifts ever made, and can be operated while walking behind the Plow as well as in the seat. The Seat is adjustable, so that the operator sits in a level position. It is made very durable, mostly of steel and malleable iron, and is warranted to do as good work on the level land, turning furrows all one way; and more than that, it works perfectly on side-hills. All that the farmer needs in the Plow line is contained in this one Plow, viz., two flat-land Plows, right and left hand, a reversible sulky Plow, either for the flat land or hillside. By removing one Plow you have a single sulky Plow, either right or left hand, as you wish. Every Plow and every part is made of steel or Iron, except the pole. In fact, not a thing has been left undone that could be done to make this the best Sulky Plow in the world.

\section{The Imperial Plow}

Oyer 200,000 in use. Best general-purpose Plow in the world. We respectfully call the attention of dealers and farmers to this Plow. We feel confident that ther will find it as well adapted for general work as any Plow in the market. The "Imperial " is the most durable, economical and desirable Plow the farmer can purchase, because : (I) It is made on correct principles and will not rack easily. (2) It is a perfect implement. (3) For one, two or three horses combined. (4) For sod, stubble and deep plowing. (5) Turns a furrow smoothly and slowly, so all trash goes underneath. (6) MIoldboards, shares, landslides and cutters are interchangeable in steel chilled or cast iron, or a combination of either. (7) Easily repaired. (8) They are equipped with jointers, steel knee, hanging and rolling cutters and wheels. (9) Of very light draft, easily handled, steady running, so boys can handle them. (Io) Adapted to any kind of soil by the interchange of parts. Try it; if not true, return it.

\section{Oliver Patent Chilled Plow}

We will carry this season a full line of the different styles and sizes of the Oliver Chilled Plow, best adapted to our New England soils. This Plow is well known in this vicinity, and its work cannot be praised too highly. Remember that every Plow made by the Oliver Chilled Plow works is offered with the absolute guarantee of being the best article of the kind that can be made for the price asked. Every Genuine Oliver Chilled Plow has stenciled on the woodwork the inscription: "Manufactured by the Oliver Chilled Plow

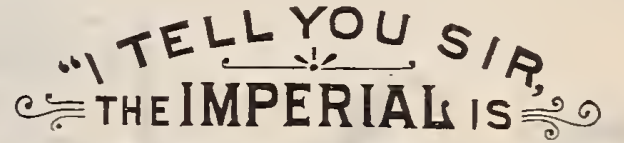

THE BEST PLOW IN THE WORLD"'

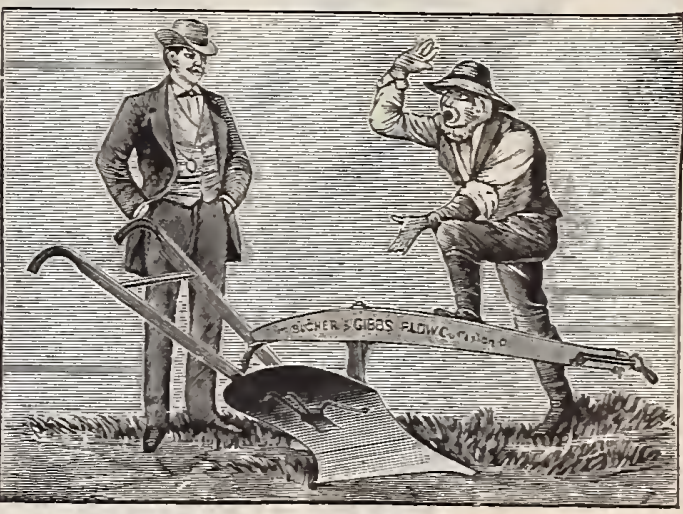

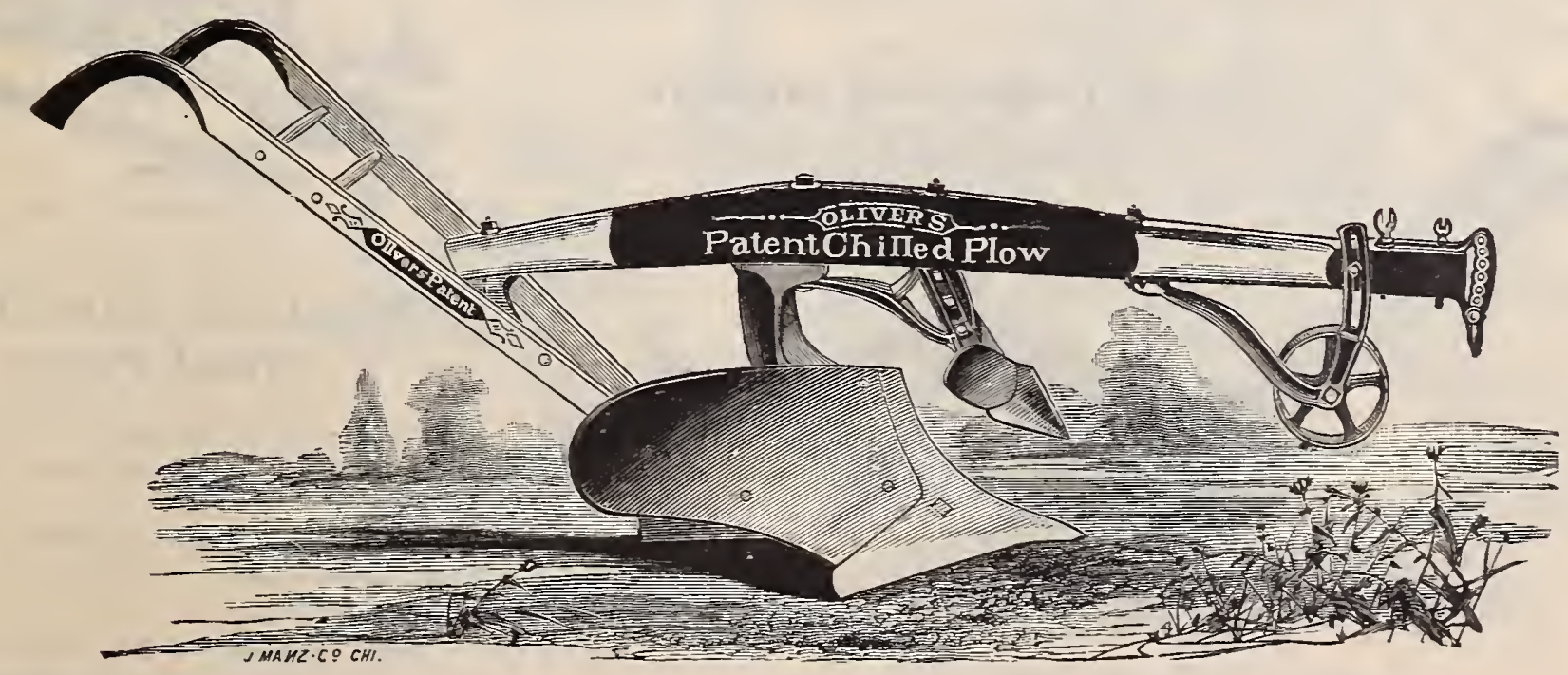




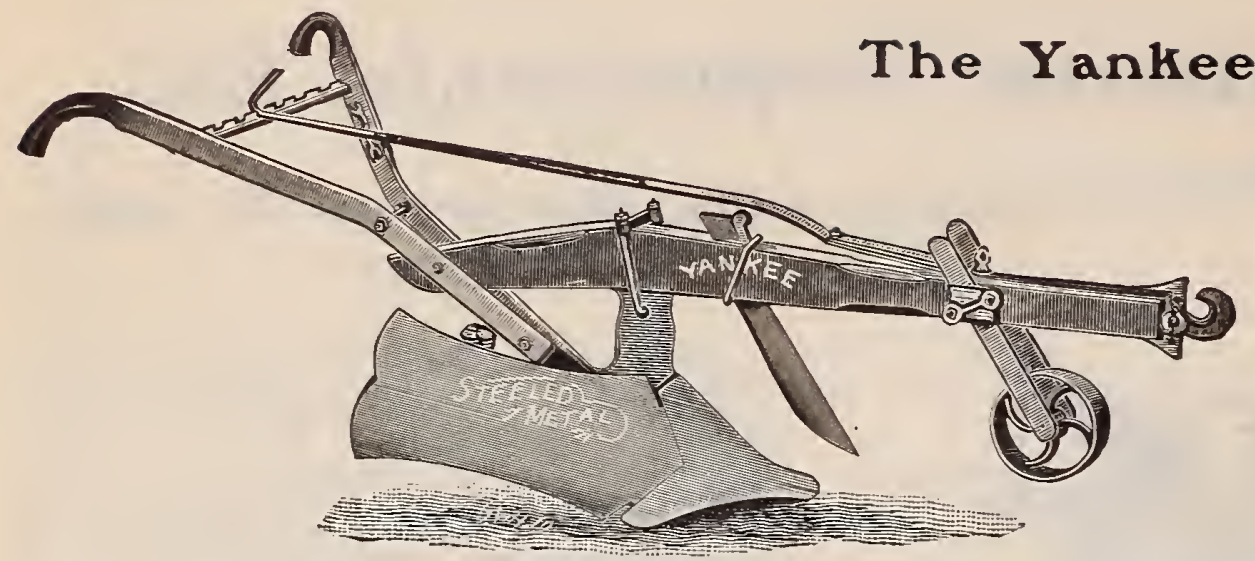

\section{Swivel Plow}

New Series, with Patent Spring Foot-Làtch, Automatlc Jointer, Straight Steel Coulters, or Rolling Castor-Coulters and all late improvements.

The construction of this Plow is such that when used with straight coulters all grass, weeds, etc., are buried as effectually out of sight as can be done with jointers on other Plows, witl a saving of at least ro per cent less draft.

Nos. $2 \mathrm{H}$ and $3 \mathrm{H}$ are made as shown in cut, with high standards and patent spring foot-latch. This latch is an invaluable improvement, as, being operated entirely by the foot, the Plow is ready for work as soon as reversed, which is done without taking the hands from the handles, or stopping the team.

It is simple, strong and durable, and does not get higher, there is more room under the beam, and there is less danger of clogging when plowing weedy land.

\section{The Arlington Swivel Plow}

The Arlington Plow has become a favorite in many sections. Moldboards are made of patent steeled metal, and all castings nicely polished. The beam and handles are made from selected stock. Their general appearance commends them to all desirous of a first-class, easy-working Plow.

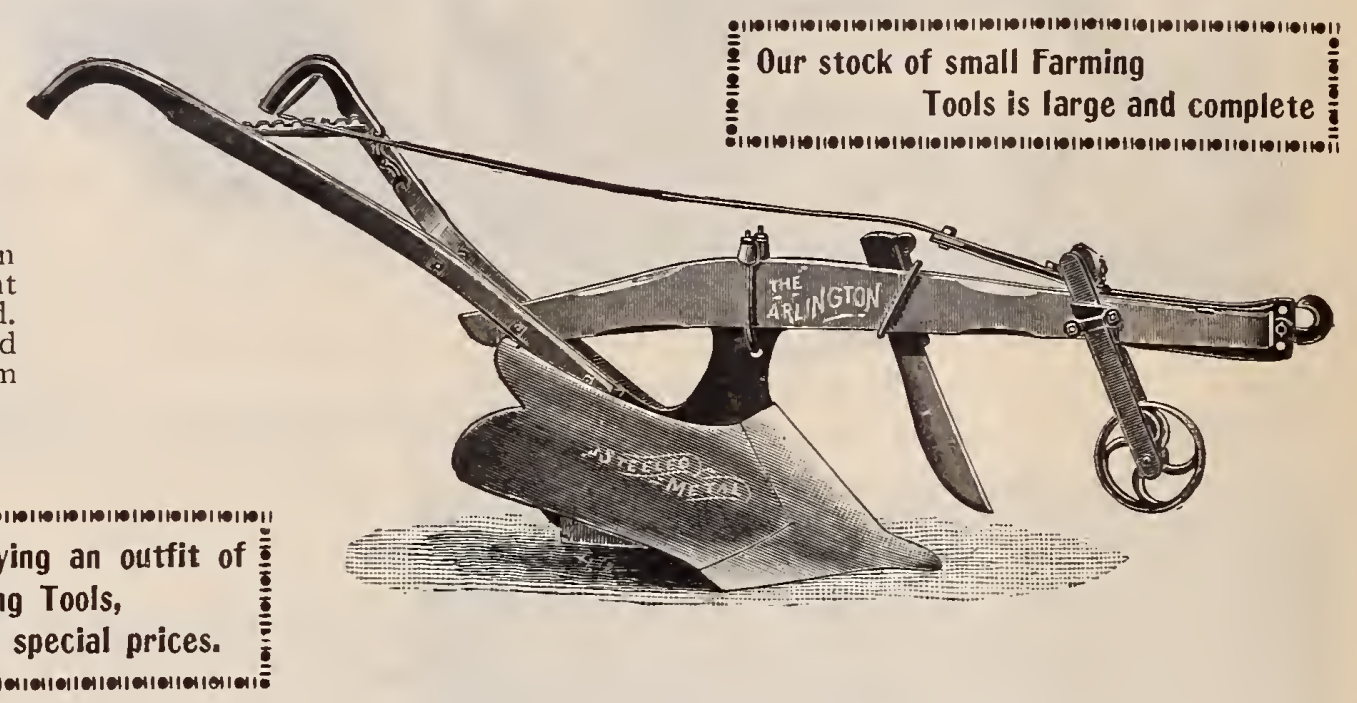

\section{The Conical Plow}

The fact that since we first introduced "The Conical" we have made and sold over 10,000 of this kind of Plows, should be a good recommendation for it. The increased demand for this Plow shows the strong hold it has among the farmers. For all kinds of soil and good work it has no equal.

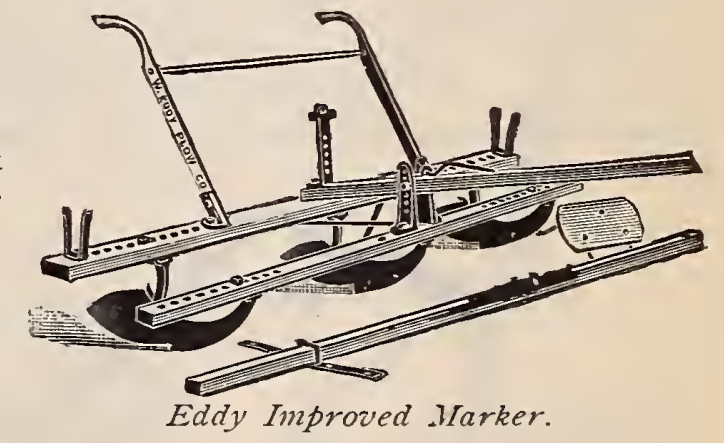

\section{Syracuse Steel=Beam Steel Plows}

No. 62-Size, medium two-horse; furrow, 5 to $7 \frac{1}{2} \mathrm{in}$. deep, ro to $13 \mathrm{in}$. wide; weight, plain, IO3 lbs.

No. 6I-Size, large two-horse; furrow, 5 to 8 in. deep, 12 to 15 in. wide; weight, plain, I08 lbs.

Well adapted to turn a deep, narrow fur. row. Steel jointer and wheel standards. 


\section{Bell's Center=Cut Disk Harrow}

The 0n1y Overlapping Center-Cut Disk Harrow in the World

There is no farming tool that covers and cultivates so much ground as a good Disk Harrow, but they are all so made that a little uncut ridge of ground is left in the center. How to reach that ridge and cultivate an even surface has been the problem. It is now solved by Bell's Center Cut. It is the only Harrow that reaches the center ridge and pulverizes all the ground from outside to inside, leaving a smooth surface

behind it. The importance of this sure cultivation to an even depth and leaving no ground uncultivated cannot be over-estimated. All centercut Harrows have one more disk than cut Harrows have one more disk than is uncultivated, the crops won't grow, but weeds will."
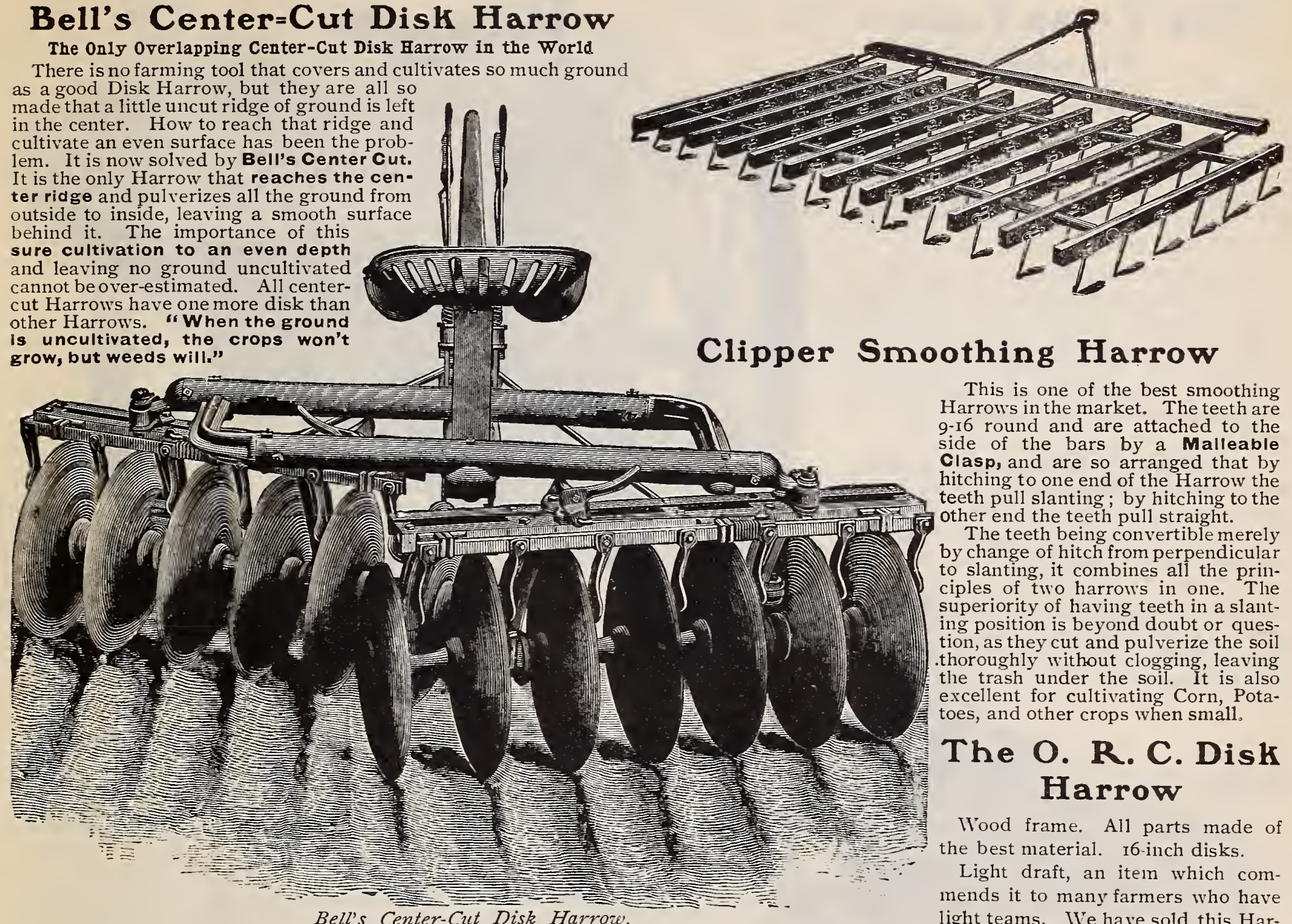

\section{Acme Pulverizing Harrow}

This is not a special tool, as some have supposed, but as its name implies, a general-purpose harrow that will do the whole business, viz.: it will crush, cut, lift, turn, smooth and level, all in one operation. Made for one or two horses.

\section{Improved Imperial Spring= Tooth Harrow}

Elevated Frame

As now manufactured is a tool that for completeness, simplicity and durability in structure and ease of manipulation has no equal. Made of all steel and malleable iron, its strength and lasting qualities cannot be excelled. Drawbar attachment such that with rear attachment, no lateral or side-toside motion, but allowing of upand-down or in-and-out-of-theground motion, same as in a flexible harrow. Distance between frame such that no trash can collect. Arrangement of teeth such that no two teeth track or line up.

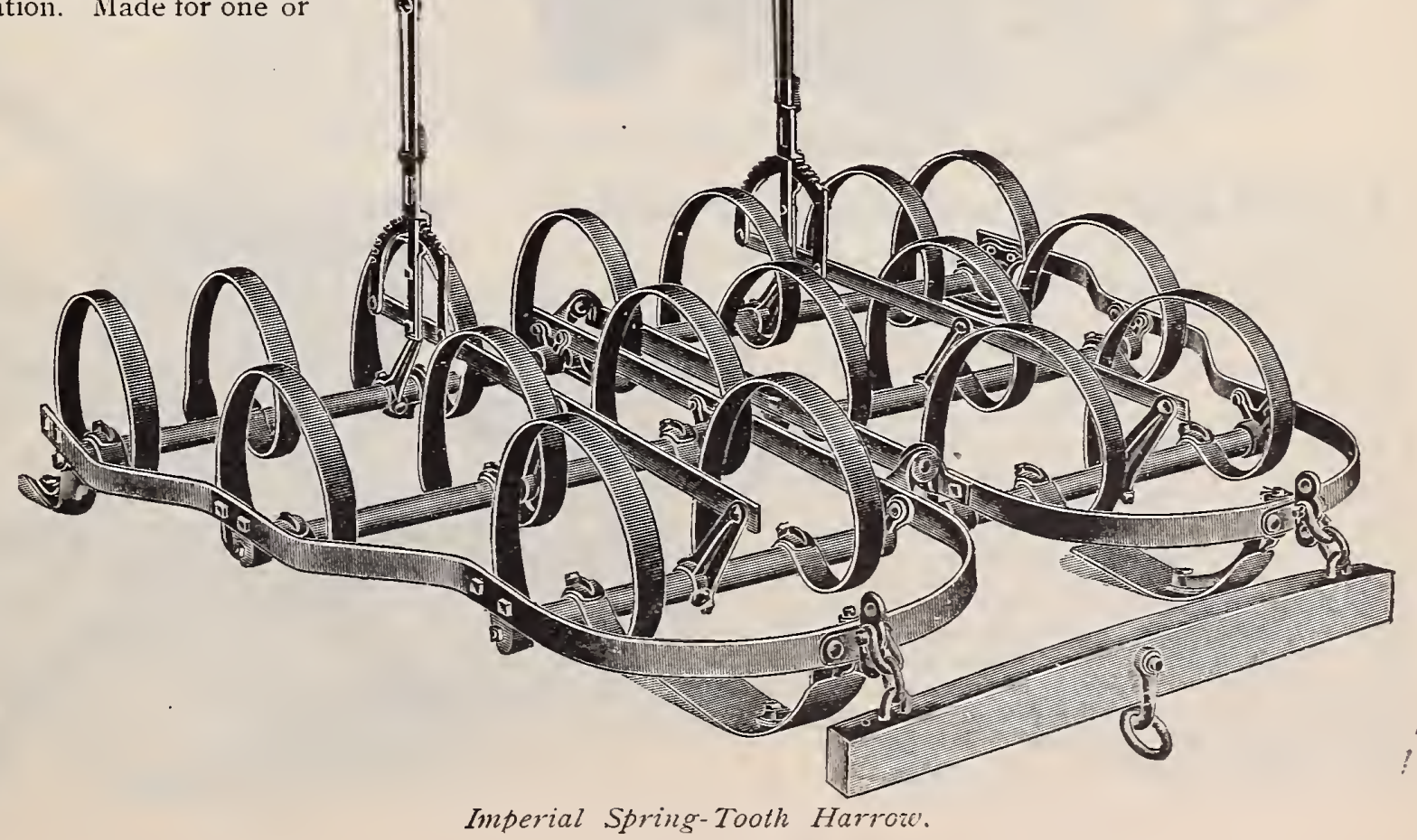

This is one of the best smoothing Harrows in the market. The teeth are 9-16 round and are attached to the side of the bars by a Malleable Clasp, and are so arranged that by hitching to one end of the Harrow the teeth pull slanting; by hitching to the other end the teeth pull straight.

The teeth being convertible merely by change of hitch from perpendicular to slanting, it combines all the principles of two harrows in one. The
superiority of having teeth in a slanting position is beyond doubt or question, as they cut and pulverize the soil thoroughly without clogging, leaving the trash under the soil. It is also excellent for cultivating Corn, Potatoes, and other crops when small.

\section{The O. R. C. Disk Harrow}

Wood frame. All parts made of the best material. 16-inch disks.

Light draft, an item which commends it to many farmers who have light teams. We have sold this Harrow for many years and can guarantee it in every respect. 


\section{The Evans Potato Planter}

WITH OR WITHOUT FERTILIZER ATTACHMENT

This machine is one of our specialties, and, without doubt, is the most improved machine of its class on the market, being strictly up-to-date in every particular.

The Feed. This being the most important part in seeding machines, and especially so in potato planters, we have constructed the feed so that there is no adjustment for large or small pieces of potato. It is a force-feed, is positive in its action, and its operation is controlled by the machine, instead of by the size of the seed potatoes.

To Change the Distance Apart in Dropping.-The machine will drop the potatoes in The change for the different distances apart is accomplished by putting on more or fewer picker arms.

The Driver Can See the Potatoes Dropping. This is a great advantage, as he then knows whether the machine is depositing the seed properly or not. drills I0, I2, I4, I6, I $8,20,28$, or 36 inches apart.
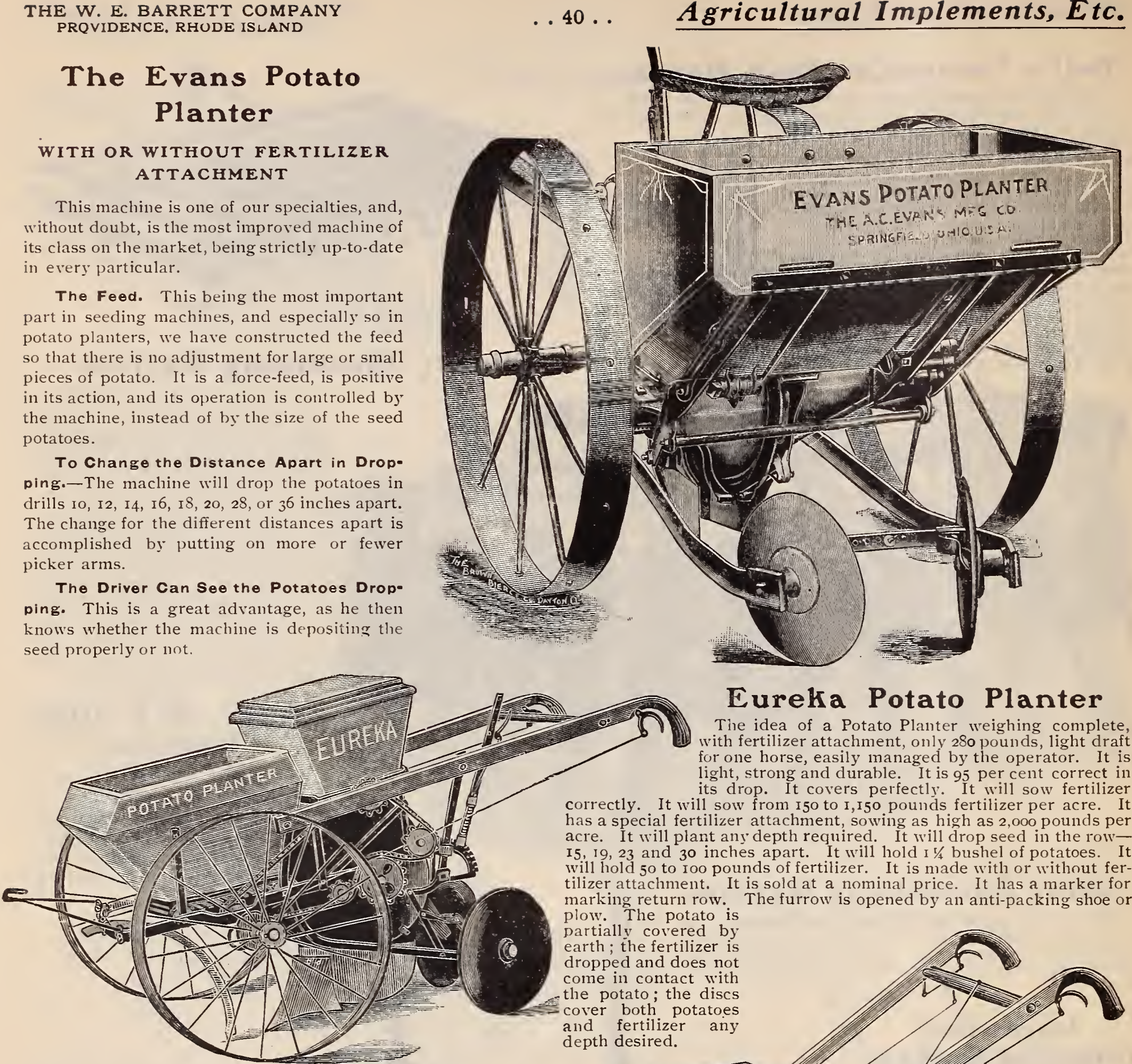

Eureka Jr. No. 3 Corn Planter

All Eureka Corn Planters have the famous Wizard Fertilizer attachment, which distributes in the rows by the best experimental stations in this country. Several changes can be made in the amount distributed, varying from one to six hundred pounds per acre. The fertilizer is dropped a little above and on each side of the seed, so that no matter how much phosphate is used or how strong it may be, it does not come in contact with the seed to injure it. All Planters have covering wheels I2 inches in diameter and 5 inches face, cover both seed and phosphate and press down the soil, insuring more rapid germination. Clods, lumps and stones a re brushed aside by wings riveted to the runners, so that the seed is covered by the best soil. They are light draft for one horse, handle nicely and run steadily.

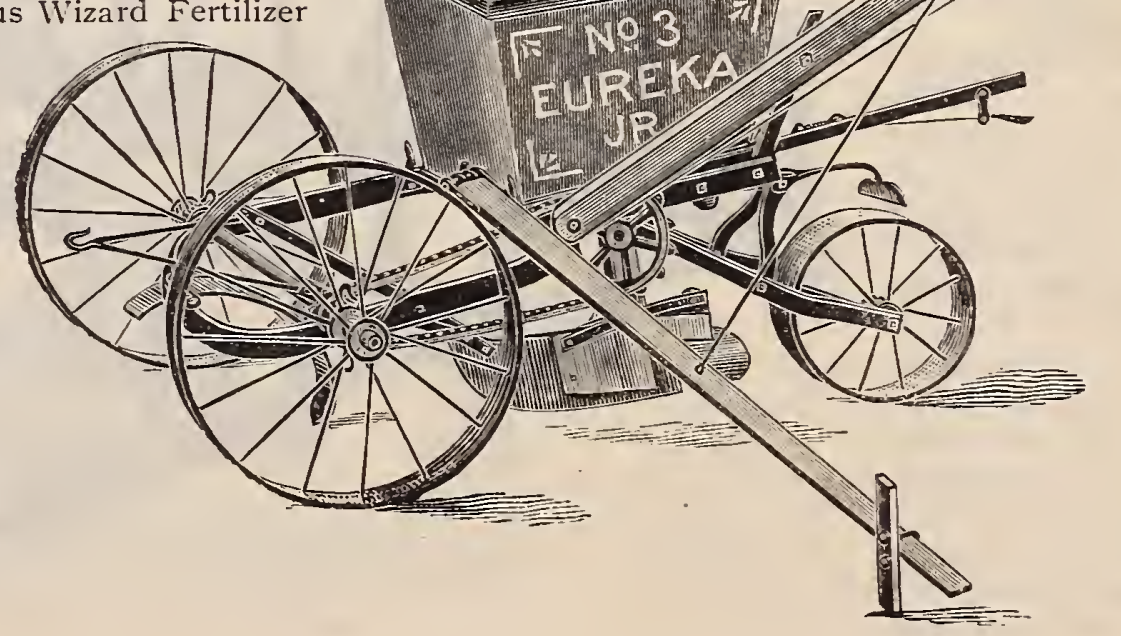

No. 3

Eureka Jr. Corn

Planter.

One Row,

Two Drive

Wheels. 


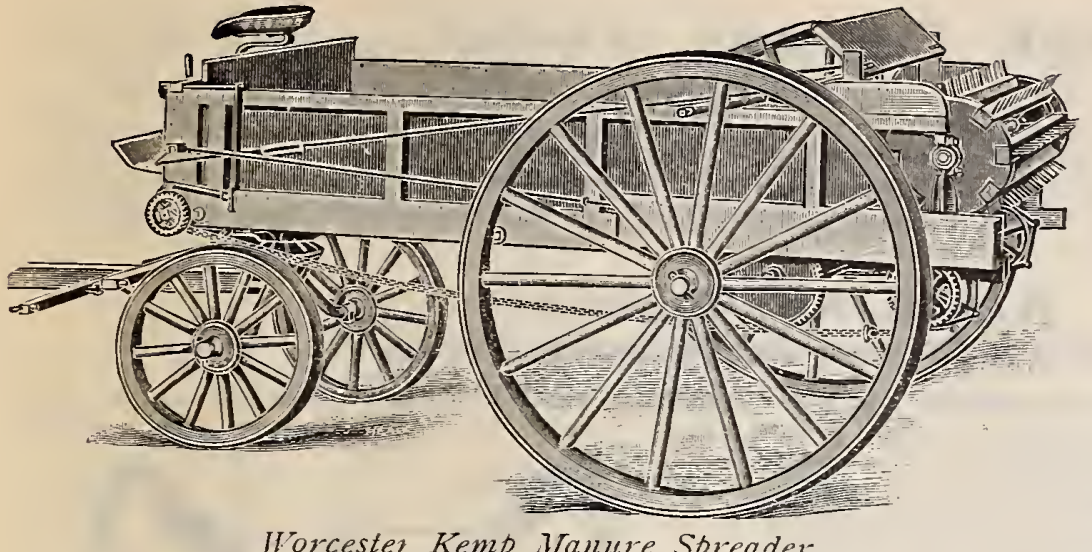

Worcester Kemp Hanure Spreader.

\section{The Worcester Kemp Manure Spreader}

Is the original Kemp Spreader, manufactured continuously since 1878 . The thousands of machines still in good condition after from to to 20 years of service are substantial evidence of their dur.dbility. It is the strongest spreader built, lightest draft, does its work with certainty, handling all kinds of manure, lime, ashes and fertilizer, accurately gauging the amount put out per acre. Free illustrated catalogue will give you the points; and the most important thing for the farmer to know is that the new Kemp Manure Spreader has been greatly strengthened in the gearing; it will spread all kinds of manure with certainty, and run day after day without breaking down; it has a rew and patented tail-board which makes tight box of the body and

\section{Perfection Drill and Fertilizer Sower}

This machine will form a drill from 3 to to inches deep, and will drop into the drill commercial fertilizers at the rate of 100 to $3,000 \mathrm{lbs}$. per acre as desired. The scrapers shown between the wheels are adjustably attached to the axle and can be placed where necessary to cover the fertilizer with dirt as desired. If preterred to mix soil with fertilizer the tooth in the rear of the machine can be used. The plow can be removed and also the gatherers under the hopper, and a space Io inches wide covered with fertilizer and left on the surface or mixed with soil by using tooth and scrapers.

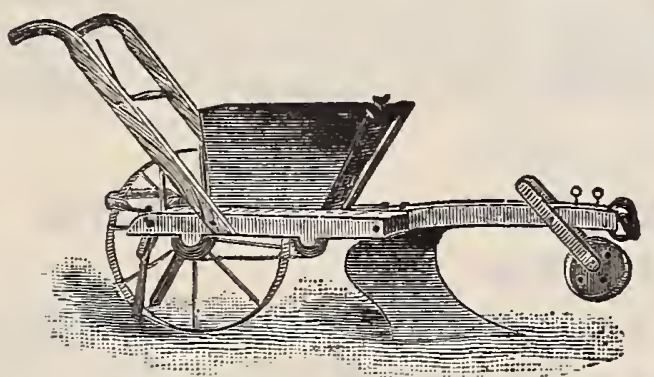

Perfection Drill and Fertilizer Sou'er

\section{Cahoon and National Hand Broadcast Seeders} prevents the manure from banking against the beater and throwing out a quantity of manure when the beater starts; it is the only Spreader having two floor chains, and the beater shaft has ball-and-socket bearings, which causes light draft. Built in four sizes.

No. I Spreader, 35-bushel capacity.

No. 2 Spreader, 40-bushel capacity.

No. 3 Spreader, 5o-bushel capacity.

No. 4 Spreader, $;$ o-bushel capacity.

They will sow wheat, rye, oats, rice, flax, millet, turnip seed, clover seed, grass seed including light grasses; in fact, all kinds of seed broadcast. Also plaster, fertilizer, salt, ashes, etc.

\section{Thompson Wheelbarrow Grass Seeder}

This is the only correct way of broadcast seeding. Seed can be sown on any kind or condition of soil, in any kind of weather, any amount per acre required, evenly and accurateiy. It can be used by any one who can wheel a barrow. There are no cogs, gears or intricate connections in its entire

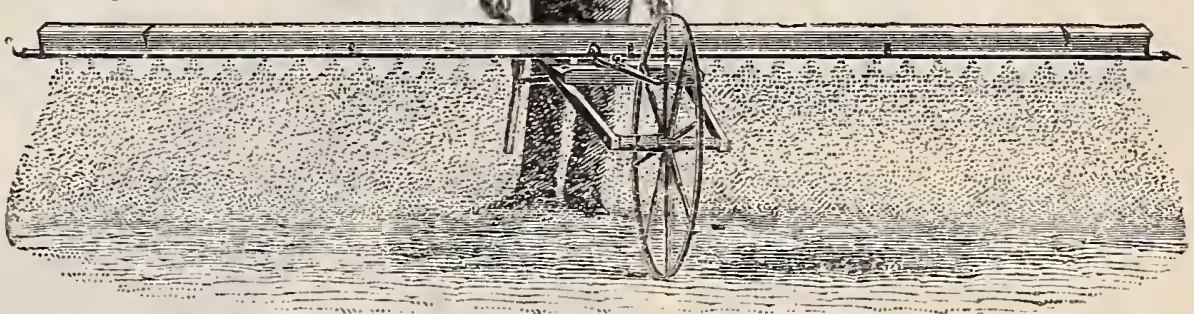
construction. Mud cannot clog its parts. It is impossible for it to sow any way but accurately, as the entire working parts are governed Dy the wheel. Lightness and strength are combined in its construction, and the large wheel ( 33 inches in diameter) makes it very easy to run. The actual weight of complete machine is about 40 pounds.

\section{"King of the Cornfield" Corn, Bean and Pea Planter and Fertilizer Distributor}

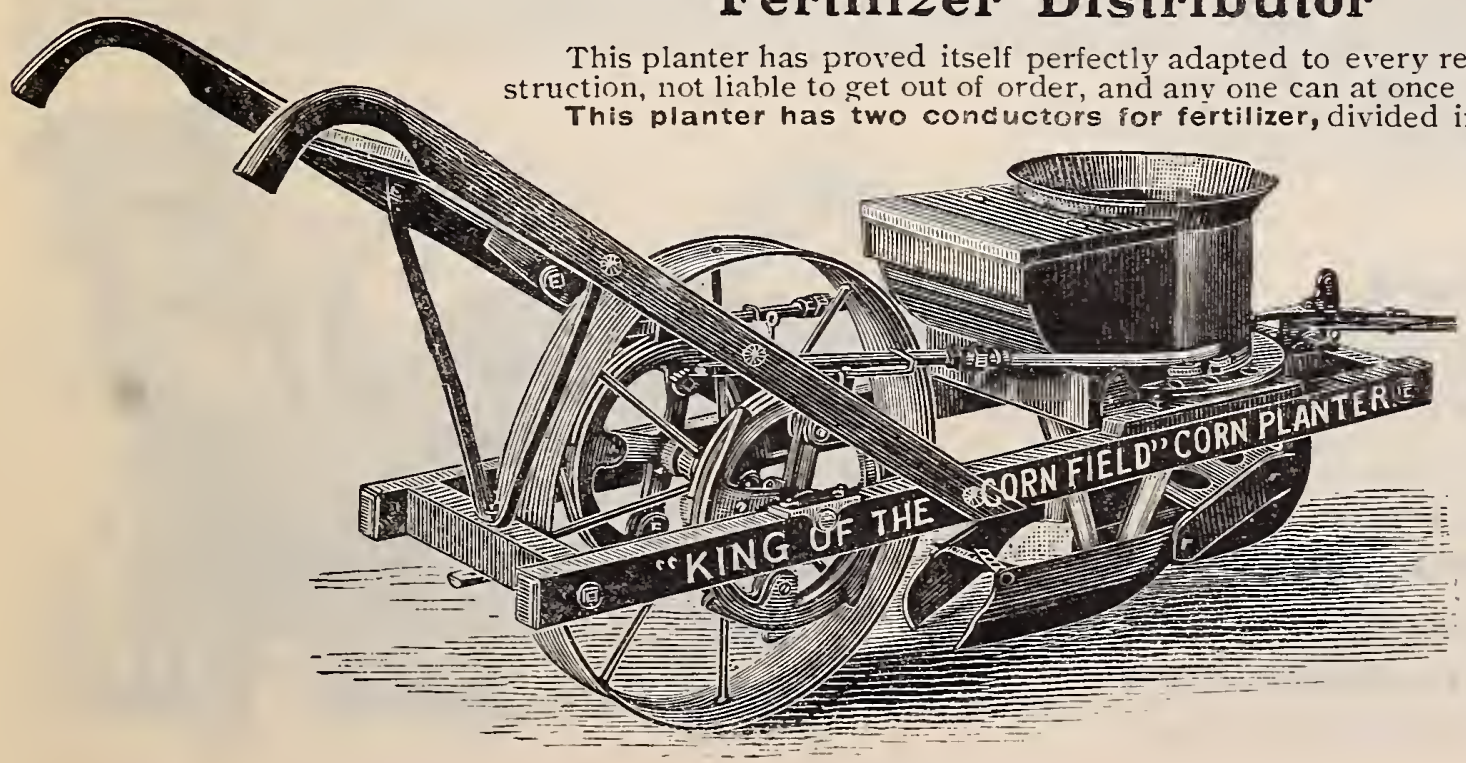

equirement; durable and simple in consuch a way as to have it fall on both sides of the seed. The fertilizer hopper is an oscillator, vibrating backward and forward in order to pulverize all lumps, which allows wet or lumpy fertilizer to be used, distributing it in equal quantities as desired. It will drop ashes as well as all commercial fertilizers, wet or dry, coarse or fine, which no other machine will do.

Plants field, ensilage, fodder and broom corn, beans, peas, pumpkins, beet or other like sized seed. This season several new and useful improvements have been added, among which we mention a new steel concave whe $\mathrm{l}$, having substituted steel in place of cast iron for the coverers and clearing plow. New-style steel drive rods, improved covers in fertilizer hopper, etc., making the machine very much lighter and stronger. 

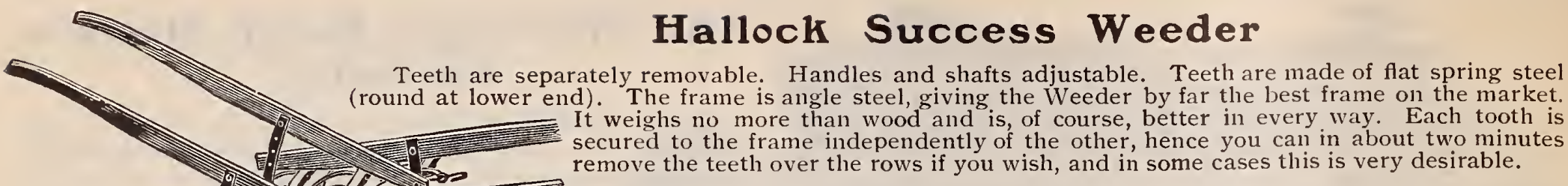

\section{Keystone Weeder}

Some Points of Superiority over Straight-Frame Weeders

The "Keystone" is the only Weeder that Is adjustable to depth and width. It can be used as a shallow cultivator, working close to the plants, between the rows, until the crops mature, long after other weeders are laid aside. The depth of cut is regulated by the wheel in front. It has no shafts that will hinder working close to the fence. It will not clog. The long curved, spring teeth are so placed and shaped that clogging is impossible. It can be weighted down; teeth will stand I5olbs. pressure. Being $\mathrm{V}$-shaped, it is not only a stronger tool than the straight-frame Weeders, but it adapts

Hallock Success Weeder. The "Keystone Adjustable" can be expanded itself much better to uneven surface. to $7 \frac{1}{2}$ feet and narrowed to 30 inches.

\section{Eureka Flat Tooth Sulky Smoothing Cultivator}

\section{SOLD WITH OR WITHOUT GRASS SEED ATTACHMENT}

For leveling the ground, for pulverizing the soil, for preparing a good seed-bed, the Eureka Flat Tooth Cultivator has no equal. The depth of cut is under the control of
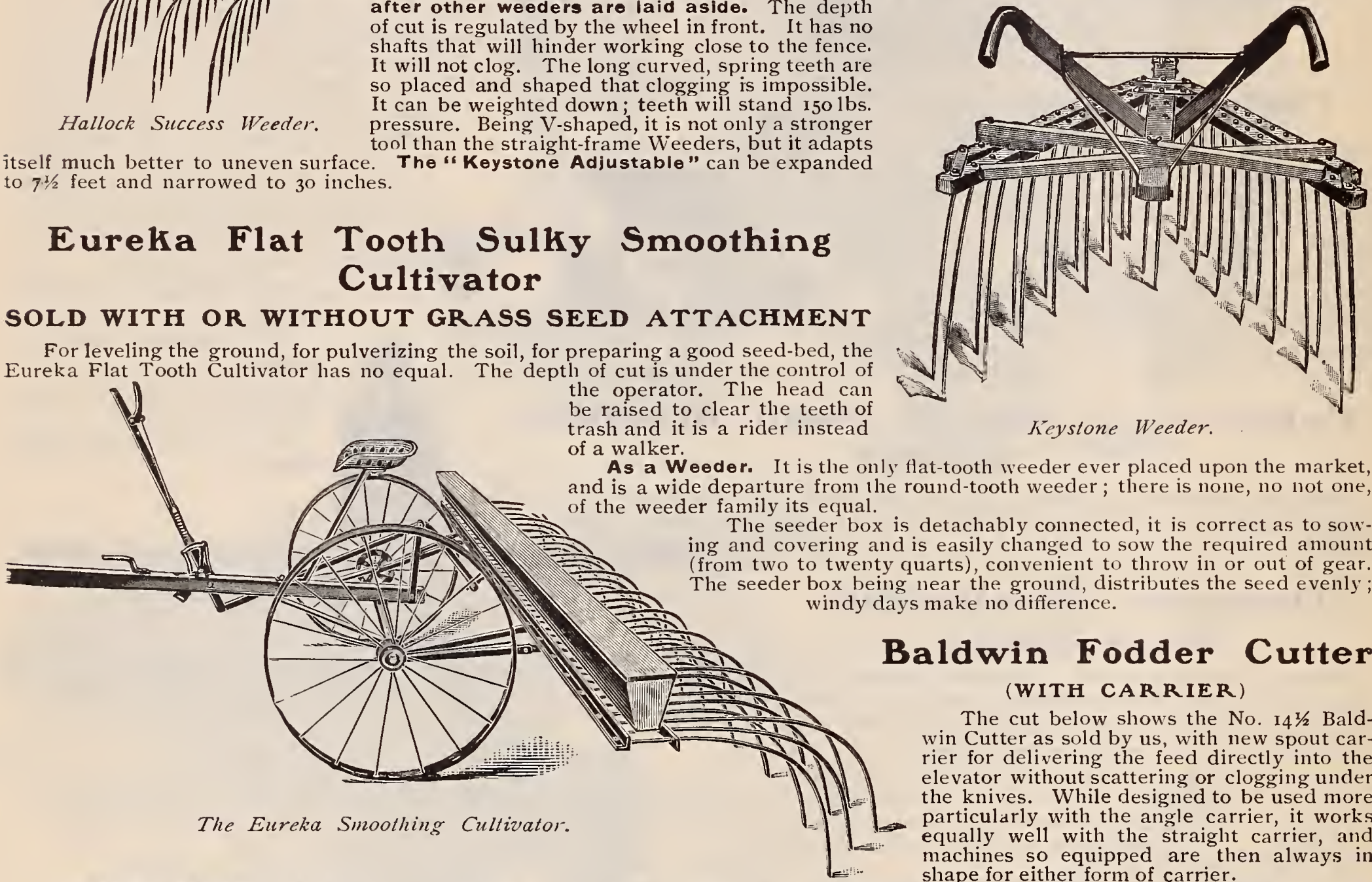

Baldwin Fodder Cutter (WITH CARRIER)

The cut below shows the No. I $4^{1 / 2}$ Bald win Cutter as sold by us, with new spout carrier for delivering the feed directly into the elevator without scattering or clogging under the knives. While designed to be used more particularly with the angle carrier, it works equally well with the straight carrier, and machines so equipped are then always in shape for either form of carrier.

The Safety Feed-Roll Lever, seen at the side of the cutter, is used to elevate the upper feed-roll, throwing the same quickly off the feed, so that the amount of feed passing through the rolls can be regulated, and all choking or clogging be prevented. When necessary from accident or otherwise, the feed is stopped instantly by pressing the treadle lever down to the floor. A touch of the foot returns it to its former position, and the work is resumed. This obviates the necessity of throwing the feed-rolls out of gear by the use of hand levers, or of slowing down the power. Being operated instantly by the foot and placed well to the rear of the machine, it is quickly and easily reached, and is attended with less danger to the operator than any device for a like purpose yet constructed. It can be readily detached so as to be used on either side of the machine.

These attachments are furnished as extras, and are provided at reasonable prices.

\section{Horse Hay Forks}

We carry in this line all the carefully tested and improved implements of today. Prominent among them you will find the well-known Palmer, Double and Triple Grapple, and Nellis' Harpoon. Call for descriptive circulars.

In our varied stock you will find

HAY PRESSES, HORSE POWERS, FARIERS'

BOILERS, STONE DRAGS,

ROAD SCRAPERS, TUBULAR IRON BARROWS

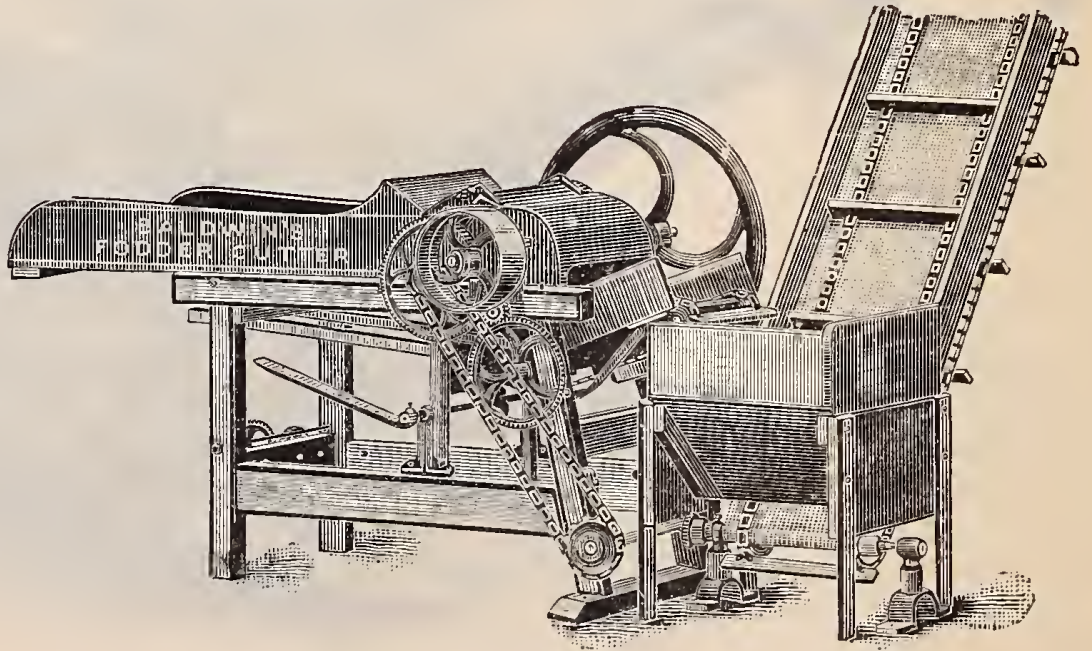

and other articles not catalogued for want of space 


\section{"Planet Jr."

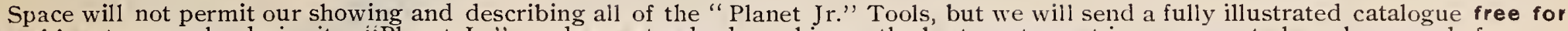

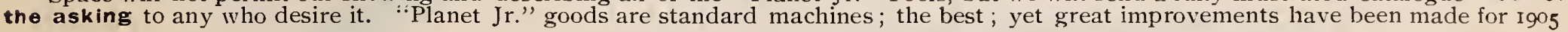

\section{"Planet Jr." No. 3 Hill=Dropping Seeder \\ Sows either in Hills or in continuous Row}

A fine Hill-Dropping Seeder, with hosts of friends, and for Igo it is greatly improved. This Drill will sow in a continuous row, with the greatest regularity but its distinctive feature is that it will drop neatly in hills either 4, 6, 8, I2 or 24 inches apart. The wheel is 15 inches high, with a broad face. It is changed in a moment from hill-dropping to drill work, sows equally well whether the hopper is full or contains only a paper of seed, and will not injure delicate seeds which are so often peeled or crushed by imperfect seeders. The plow is adjustable, and opens a very narrow furrow, which is a great advantage for after-cultivation. Capacity, 3 quarts.

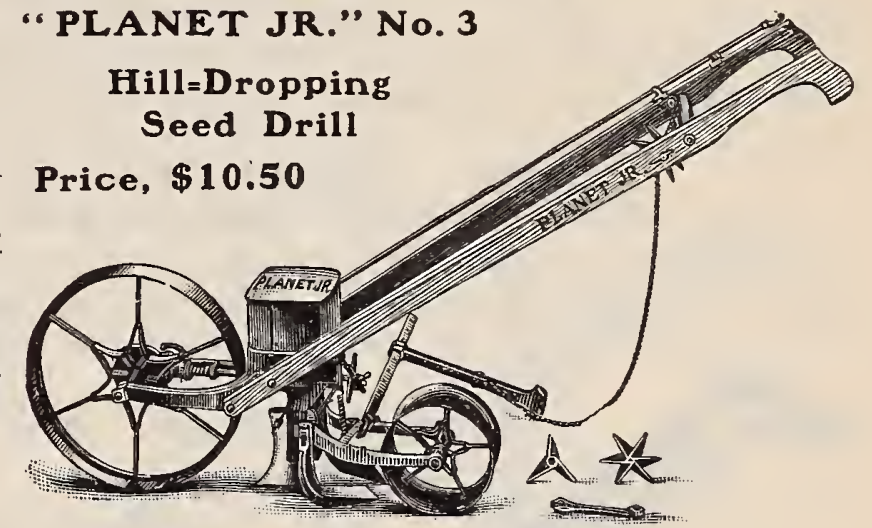

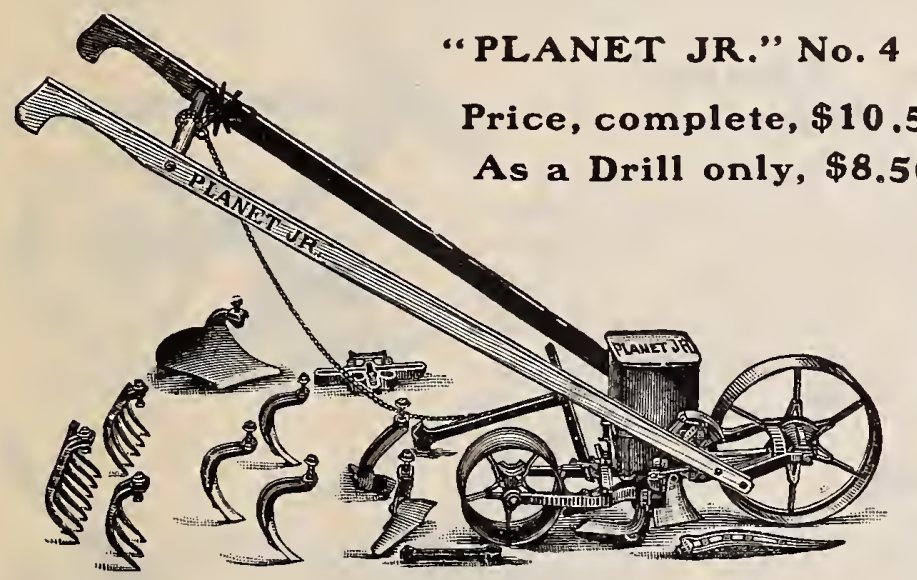

"Planet Jr." No. 25

\section{Combined Drill and Double Wheel=Hoe}

This new combined machine holds $2^{1 / 2}$ quarts. As a Drill it is almost identical with the No. 4, and as a Wheel-Hoe is identical with No. I2 Double Wheel-Hoe. The change from Drill to Wheel-Hoe takes but a moment.

The simplicity and perfect working of this tool, both as a seeder and as a Wheel-Hoe, make the combination thoroughly practical. The accuracy of the seeder in sowing all varieties of garden seeds, whether in hills or drills, and the adaptability of the Wheel-Hoe to various kinds of garden and field work, make a perfect tool.

\section{"PLANET JR." No. 11 \\ Double Wheel=Hoe, Cultivator, Rake and Plow}

Price, \$9

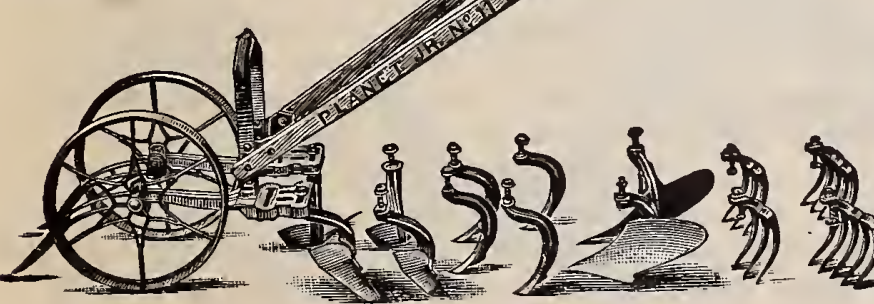

“Planet Jr." No. 4 Wheel=Hoe, Cultivator, Rake and Plow

This is exactly the same style of seeder as the No. 5 "Planet Jr." Hill opper. It is smaller in capacity, though still of good size, holding 2 quarts. handling the smallest paper of seed perfectly, and is simple, durable and very The index is accurate, plain and easily set. The drill is detached and the tool admirable Single Wheel-Hoes of the "Planet Jr." family.

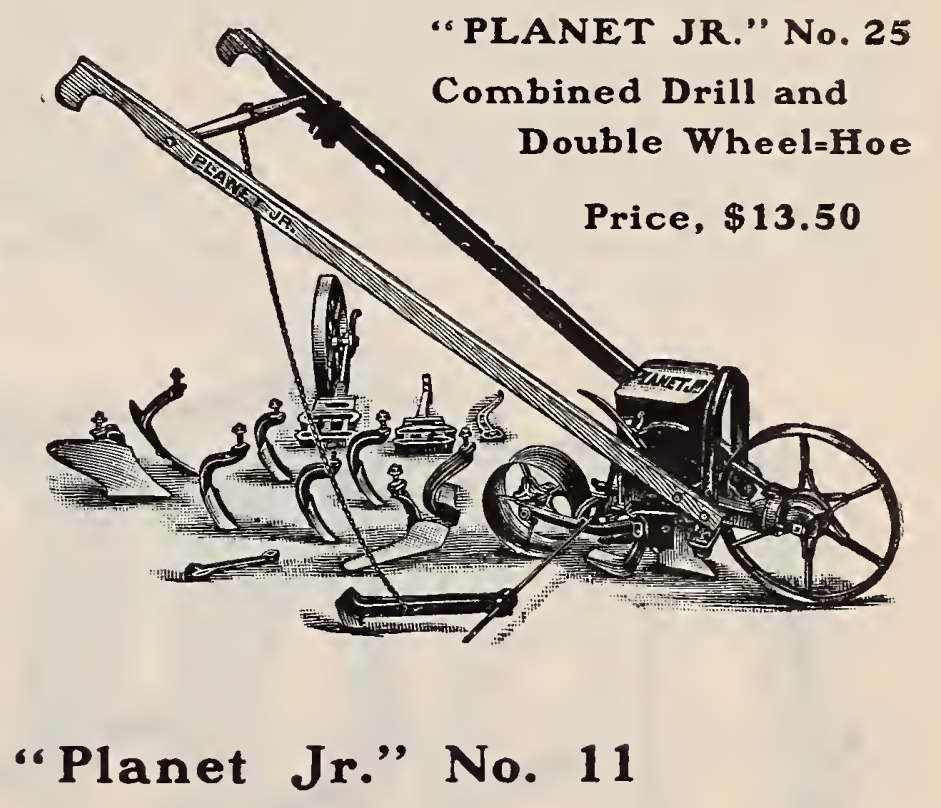

This tool has I $\mathrm{x}$-inch wheels, which can be set at four different distances apart; malleable frame, with ample room for tool adjustment, and can be set at three different heights. Adjustable handles, and, being attached to the arch, are entirely undisturbed in making changes of frame, width of wheels or in the adjustment of the tools themselves. The arch is of stiff steel, unusually high. The design of the frame is novel, allowing all changes of tools to be made without removal of the nuts from the standards. The variety of work possible with this machine is incredible, covering the whole range of WheelHoe work, and has our unqualified endorsement. 


\section{“Planet Jr." No. 12}

This tool is identical with No. Ir, except that it has la less complete equipment, as shown in the cut, but at a correspondingly less price. The set of tools with No. 12 is what gardeners need most, and the rest can be added as wanted.

\section{The "Planet Jr." No. 13 \\ Double Wheel=Hoe}

This tool is the No. I I with 6-inch hoes only. Any or all of the No. II tools may be added at any time, and are sure to fit. Price, \$4.75.

\section{The "Planet Jr." No. 16}

Single Wheel-Hoe, Cultivator, Rake and Plow

This Wheel-Hoe is identical with No. ${ }^{5}$, except that it has fewer tools, but the price is proportionately lower. The equipment is a most useful one, and will be found just right for a great variety of work. Price, \$5.85.

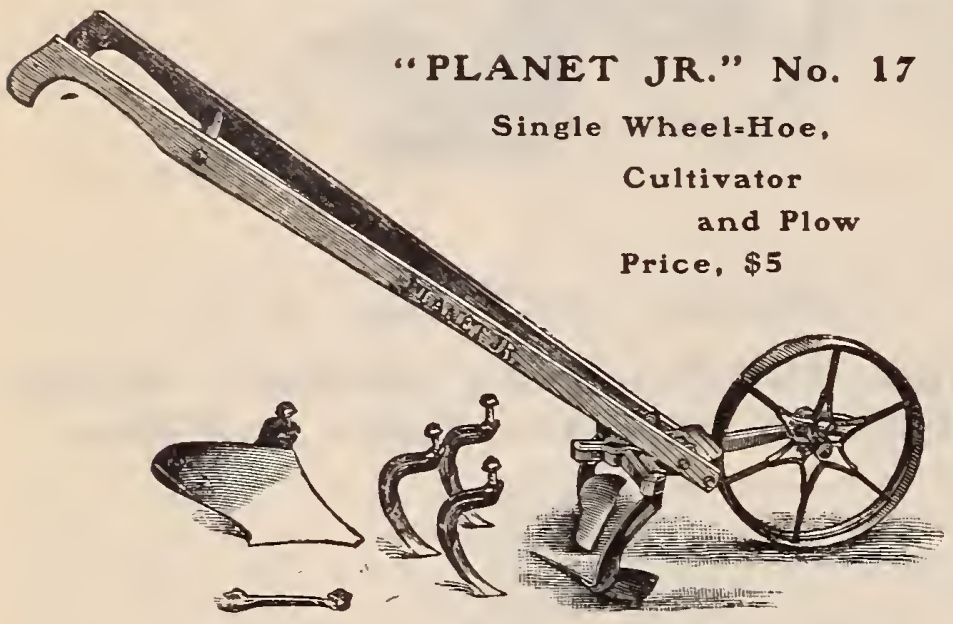

\section{The "Planet Jr." No. 18 Single Wheel-Hoe}

With the same frame and handles as No. I5, but it has I pair of 6-inch hoes only, but they are the most useful of all the list. Price, \$3.50.

\section{New Universal Seed Drill}

The accompanying illustration represents the latest improvements in Seed Drills by Mr. A. H. Matthews, who has been engaged for more than 2I years in the manufacture of Garden Seed Drills. The patent indicator, bearing the names of the different seeds, is conveniently located. To adjust the drill for planting it is only necessary to turn the indicator around until the name of the seed to be planted comes to the indicator-pin at the top. The hole thus presented in the center of the seed-box may then be gauged to a nicety by means of the regulator, which is lield by a thumb-screw. This tool, already a standard, will now be found as nearly faultless as a Drill can be made. It has never been denied that as a Seed Drill the Matthews has no superior. The cardinal principles in its construction are used in every Drill worth having now in the market.

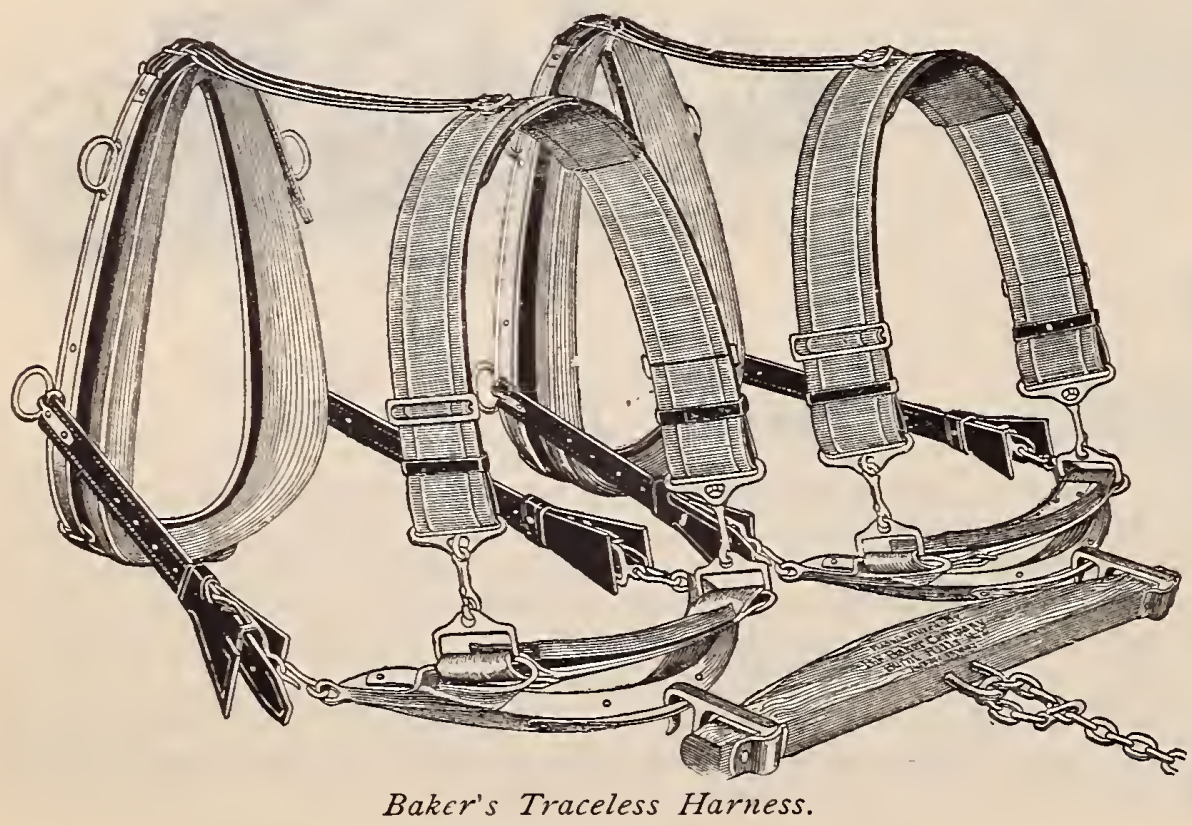

\section{"Firefly" Plow}

This tool is valuable for those have The moldboard is tempered and polished steel. The depth be changed very quickly. The low price brings it within the reach of all. ery useful to plow up the chicken yard. Prlce, \$2.35.
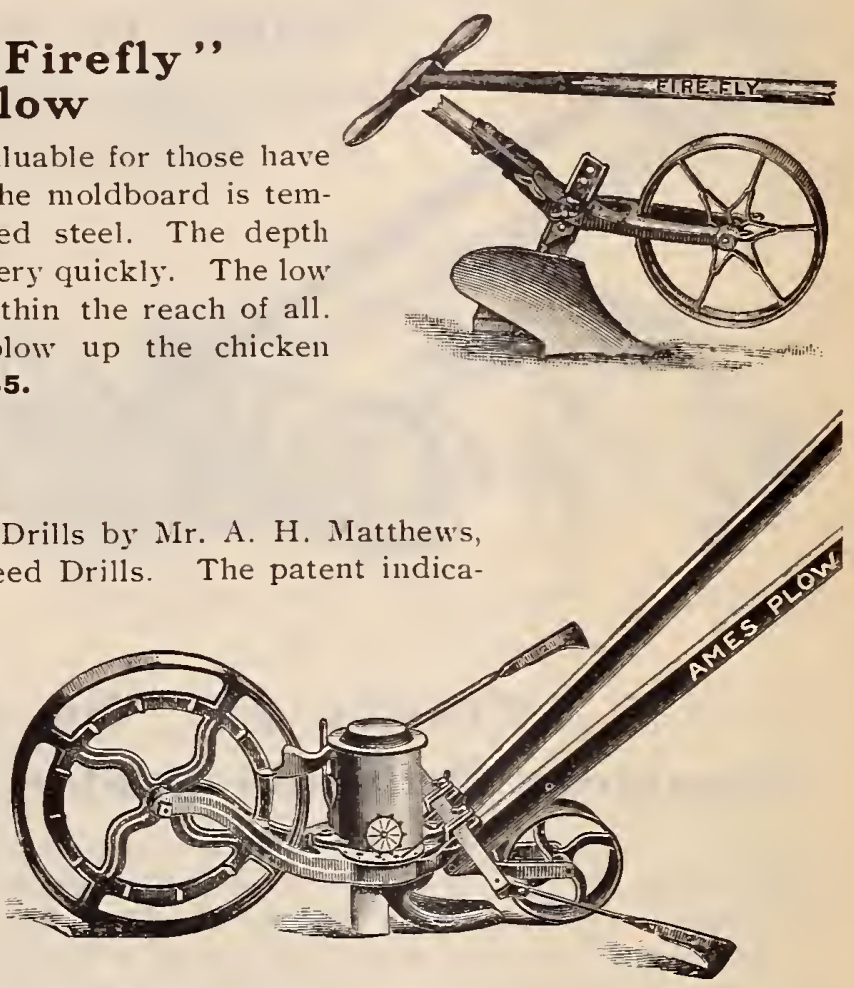

\section{Baker's Traceless Harness}

This Harness is the result of many years of labor and practical experiment, and having been perfected in every detail and subjected to the most severe tests everywhere, is now offered to the public on its merits, and with full confidence that it meets in every respect the demand for some means of doing away with the whiffletrees and traces which are so generally objectionable in all our low-down farm work. Up to this tinie the only device offered has been the very heavy and rigid Steel Harness, which has been condemned not only as awkward and cumbersome, and as often more damaging to the trees and vines than the whiffletrees themselves, but as adding to the labor of the driver, by the great difficulty of harnessing and unharnessing, and to the discomfort of the team by its excessive weight, extreme rigidity and known tendency to chafe and gall, many teams absolutely refusing to work in it at all. 


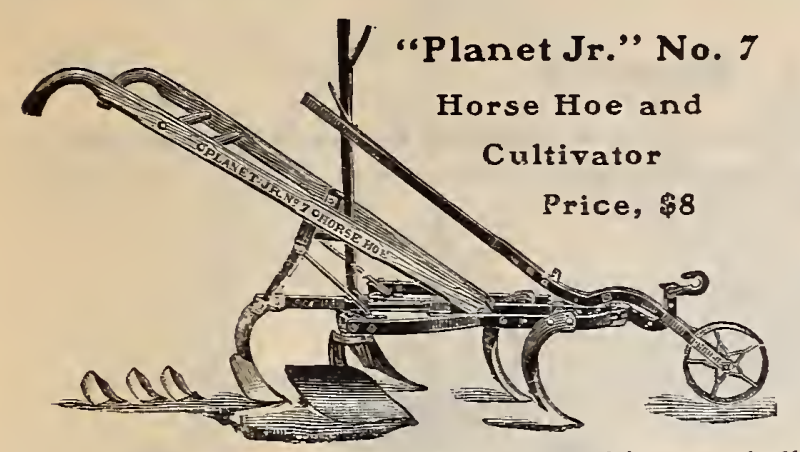

\section{"Planet Jr." No. 7 Horse Hoe}

Probably no other cultivating machine is so widely known as the "Planet Jr." Combined Horse Hoe and Cultivator, for it is in use throughout the civilized world. It is so strongly built as to withstand incredible strain, yet it is light and easy to handle.

The Expander. This is an entirely new pattern, superior to all other forms: exceedingly strong, simple, accurate and positive in all positions.

Handle and Braces. These are also new and the most effective and stiffest combination known, at once making the tool rigid, yet allowing every adjustment of handles in height and sidewise.

The Reversible Side Hoes, patented, are an important part of the implement. As shown in the cut, they act as plows or hillers, but when turned end for end the tool becomes a genuine horse hoe, working so shallow and close, without injury to the roots, that an immense amount of hand labor is avoided.

\section{"Planet Jr." No. 9 Horse Hoe and Cultivator}

No. 9 is identical with No. 7 Horse Hoe, except that it has a bolted star wheel instead of one operated by a convenient lever. The slight difference in price in favor of No. 9 will recommend it to some, though an increasing majority appreciate the great convenience of the lever wheel, and consider that it saves the trifling difference in cost almost every day it is in use. It is always convenient.

“Planet Jr." No. 5 Horse Hoe and Cultivator
There is still some demand ior the No. 5, which is similar to No. 9. Price, \$6.50.

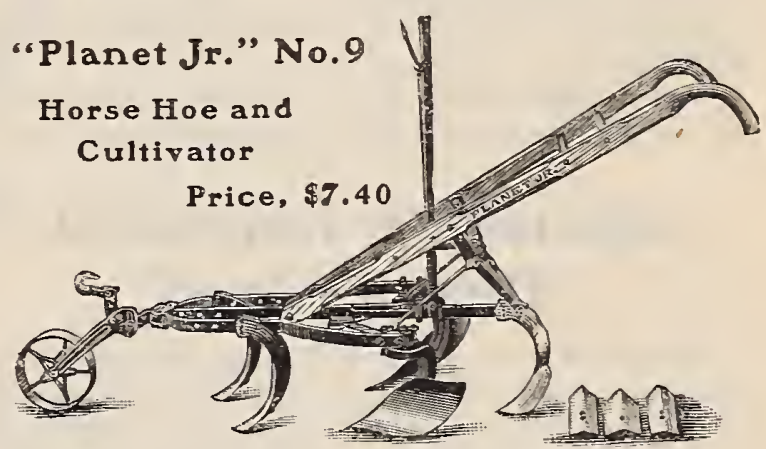

\section{"Planet Jr." Twelve=Tooth Harrow, Cultivator and Pulverizer}

\section{Price, plain, $\$ 5.80$; with wheel, $\$ 6.90$; complete, $\$ 3.50$}

This thorough working and convenient tool has rapidly grown in favor among strawberry-growers, market-gardeners, truckers and farmers. This is because the I2 chisel-shaped teeth do such thorough work, without throwing earth on small plants, and because the tool

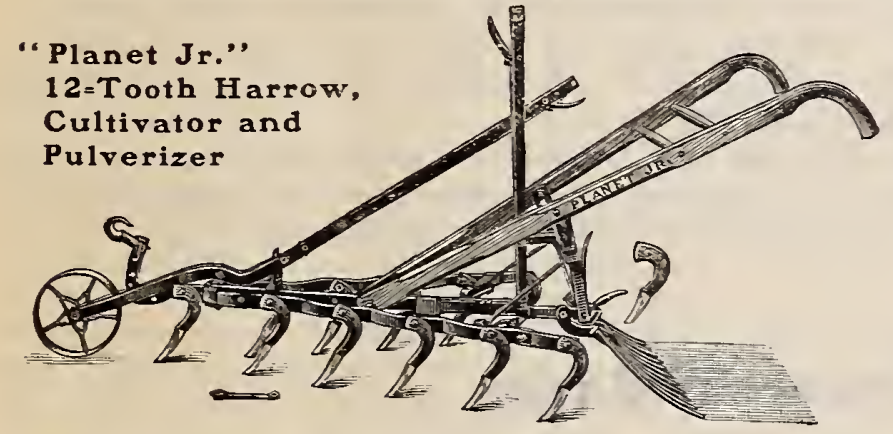

\section{Ajax Horse Hoe and Cultivator Combined}

WITH THE NEW PATENT ADJUSTING LEVER ATTACHMENT

This is one of the most durable implements of its class on the market. Has steel frame and standards throughout, and tempered crucible steel plates, which combine strength, durability and lightness. The price is lower than that of any other firstclass machine.

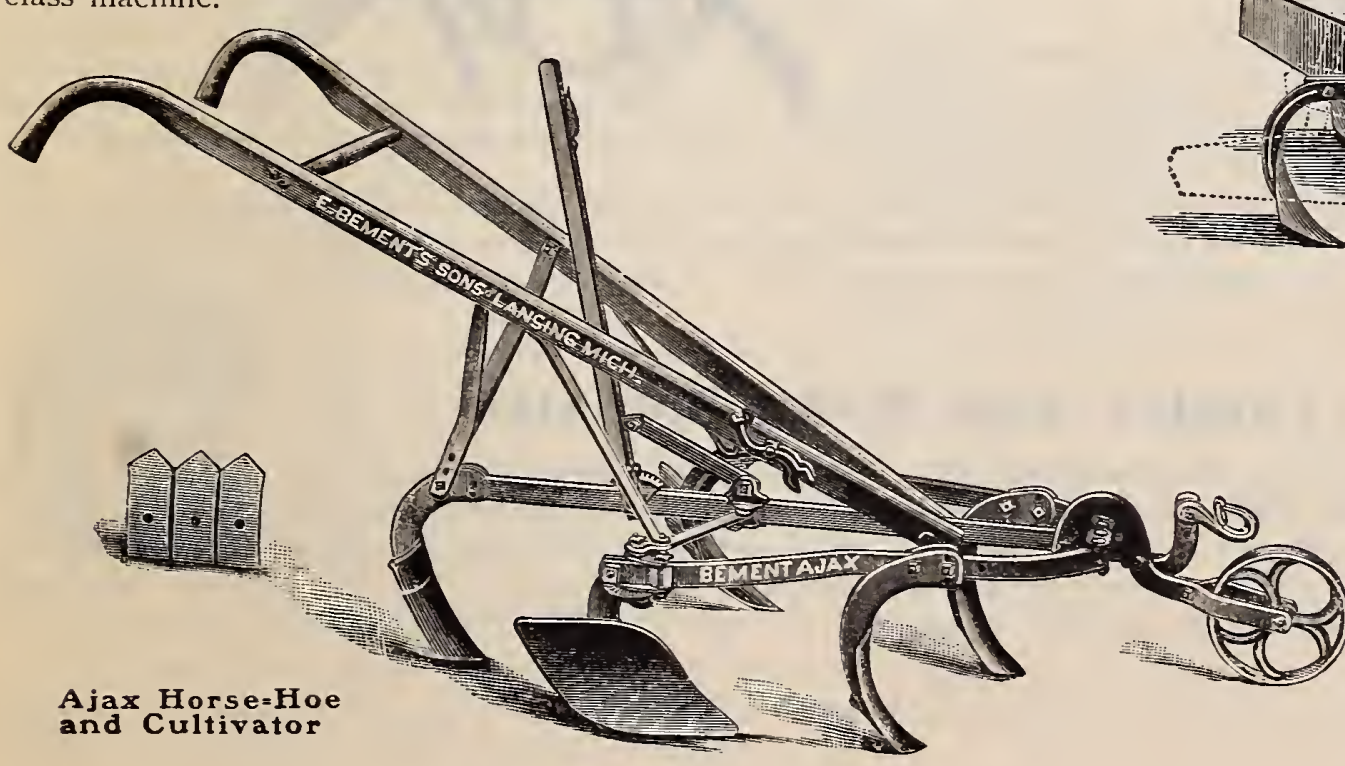

\section{New England Horse Hoe}

Although introduced to eastern farmers but a few seasons since, this Cultivator has sprung at once into rapid and well-deserved popularity. As shown in the cut below, it consists of a cultivator with two broad hilling wings attached, and a strong iron frame that cannot be injured by exposure to the weather, or liable to breakage in hard soils. When wanted as a cultivator, the hilling wings can instantly be detached and hung on the rod that passes through the handles, by simply removing three thumb nuts. Then by lowering the two teeth which have been previously pushed upwards on top of the frame, and fastening them securely in their places, it becomes a good, thorough pulverizing cultivator. By such an arrangement all risks of mislaid parts is entirely avoided. We confidently recommend this implement to all desirous of good, strong, serviceable machine, well adapted for use in all kinds of soil.

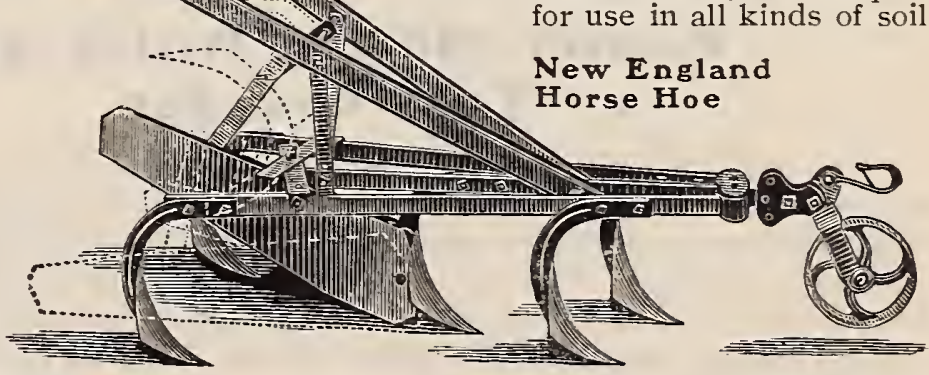

\section{Diamond Tooth Culti= vator}

This is the most complete and perfect tool of the kind on the market, combining as it does, a field cultivator and superb garden harrow and pulverizer. It has fourteen $5 / 8 \times 7 / 8$ steel diamond teeth, drawn to a cutting edge on one end. Bya very simple device the slant of the teeth can be changed so that the tool can be made a perfect smoothing harrow. It is especially adapted for getting out dog grass and heavily matted root weeds. Greatly improved for this season, having a wheel and expanding lever. 


\section{The Worcester Buckeye Mower}

The season of 1904 was a memorable one, and marked an era of greater development in the Worcester Buckeye Mower than ever before in its history. This season saw the perfect development of the new Standard Gear Mower, with its new foot-lever, a new tilting device, increased speed, greater strength, and many other improvements. It is generally admitted that the 1904 Mower was the best ever produced.

The 1905 Mower is fully up to the standard of the past in every respect. We give our patrons their choice of a wooden or a steel pitman and leave it to the user to decide which is best. At the crank end of the pitman is a double self-oiling box with a reservoir for oil, woolfilled, which diffuses oil freely. A brass bushing revolves inside of the pitman box, making a double wearing surface.

The ball scythe head is made hollow, with an oil channel opening on both sides for diffusing oil.

We mention here only a few of the new features. An illustrated and descriptive catalogue free to all.

\section{Bullard's Improved Hay Tedder}

This Tedder has a fork outside each wheel; the distance between the wheels is nuch lessened, and the Tedder much easier handled by a light horse. Also the grass passed over by the wheel is picked up
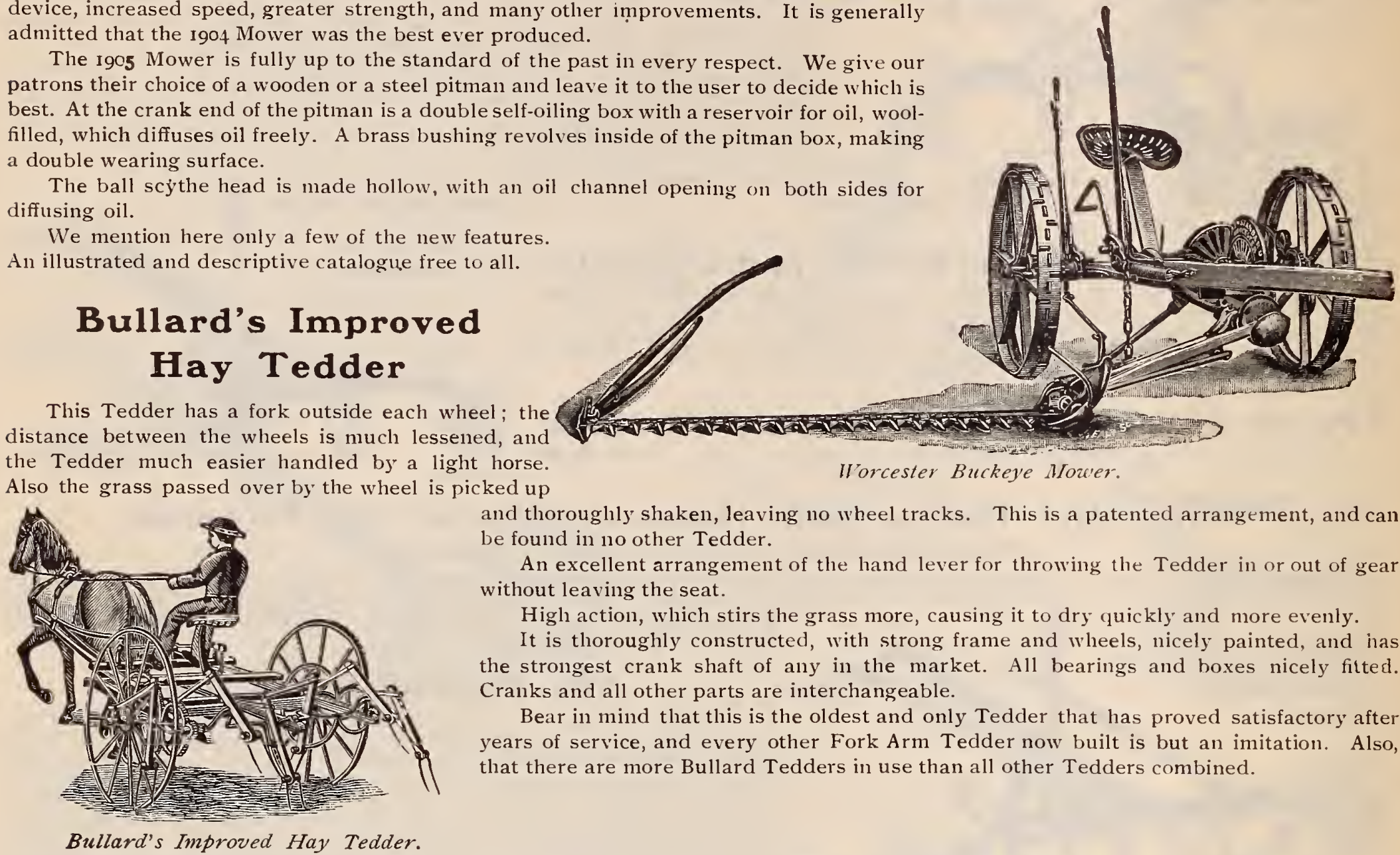

and thoroughly shaken, leaving no wheel tracks. This is a patented arrangement, and can be found in no other Tedder.

An excellent arrangement of the hand lever for throwing the Tedder in or out of gear without leaving the seat.

High action, which stirs the grass more, causing it to dry quickly and more evenly.

It is thoroughly constructed, with strong frame and wheels, nicely painted, and has the strongest crank shaft of any in the market. All bearings and boxes nicely fitted. Cranks and all other parts are interchangeable.

Bear in mind that this is the oldest and only Tedder that has proved satisfactory after years of service, and every other Fork Arm Tedder now built is but an imitation. Also, that there are more Bullard Tedders in use than all other Tedders combined.

Bullard's Improved Hay Tedder.

\section{Steel Tedders}

As there is a demand for a Steel Tedder, we offer this season the Lion All Steol Tedder and the O. R. C. Tedder, which has steel wheels and a wood frame. Both these Tedders have the Coil Relief Spring Fork. These machines are firstclass in every respect. Descriptive circular with full particulars free on application.

\section{Fowler Mower Knife and Tool Grinder}

This Grinder ranks first among all tool sharpeners. It can be adjusted to any position by means of the ball and socket joint, and it puts a perfect bevel or sharp edge on sections, scythes, feed-cutter knives or any other edged tools without extra wheels or appliances. The bar is perfectly free and the bevel of the section or

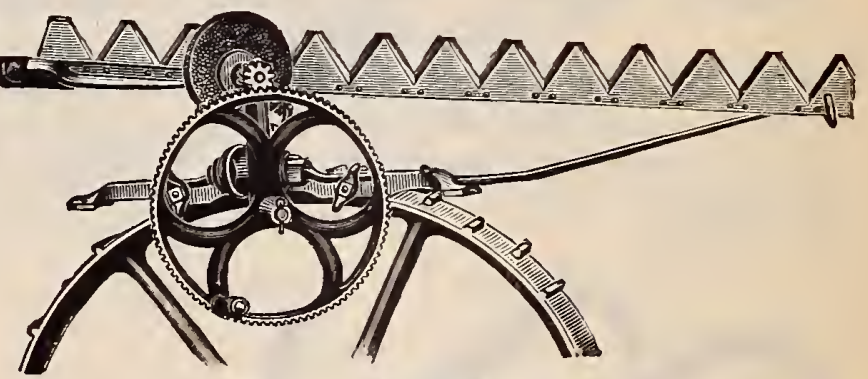

Fowler Mower Knife and Tool Grinder. cutting edge is always in plain view of the operator, and when the Grinder is once adjusted it is not changed until the work is done. It is the only machine made that will grind a broken or nicked section to a serviceable edge, and with it the most difficult and despised job on the farm becomes a pleasure. Sharp mower knives make light, elean work and save wear and tear on machine and team. Upwards of Ion,o00 of these Grinders are now in use.

\section{Mower, Tedder and Rake Repairs}

In buying a mower, tedder or rake, it is important to know about repairs for the same. When new this will not trouble jou much, although an accident is liable to occur at any time; but as your machine begins to wear, and, of course, there are some parts which will naturally wear, then you will want a new part, and when you want it you generally want it quick-you are perhaps right in the middle of haying. This is where you are protected; you don't have to wait, we have what you want right in stock. Also, four expresses a day and telephone connection with the factory. 

PROVIDENCE, RHODE ISLAND

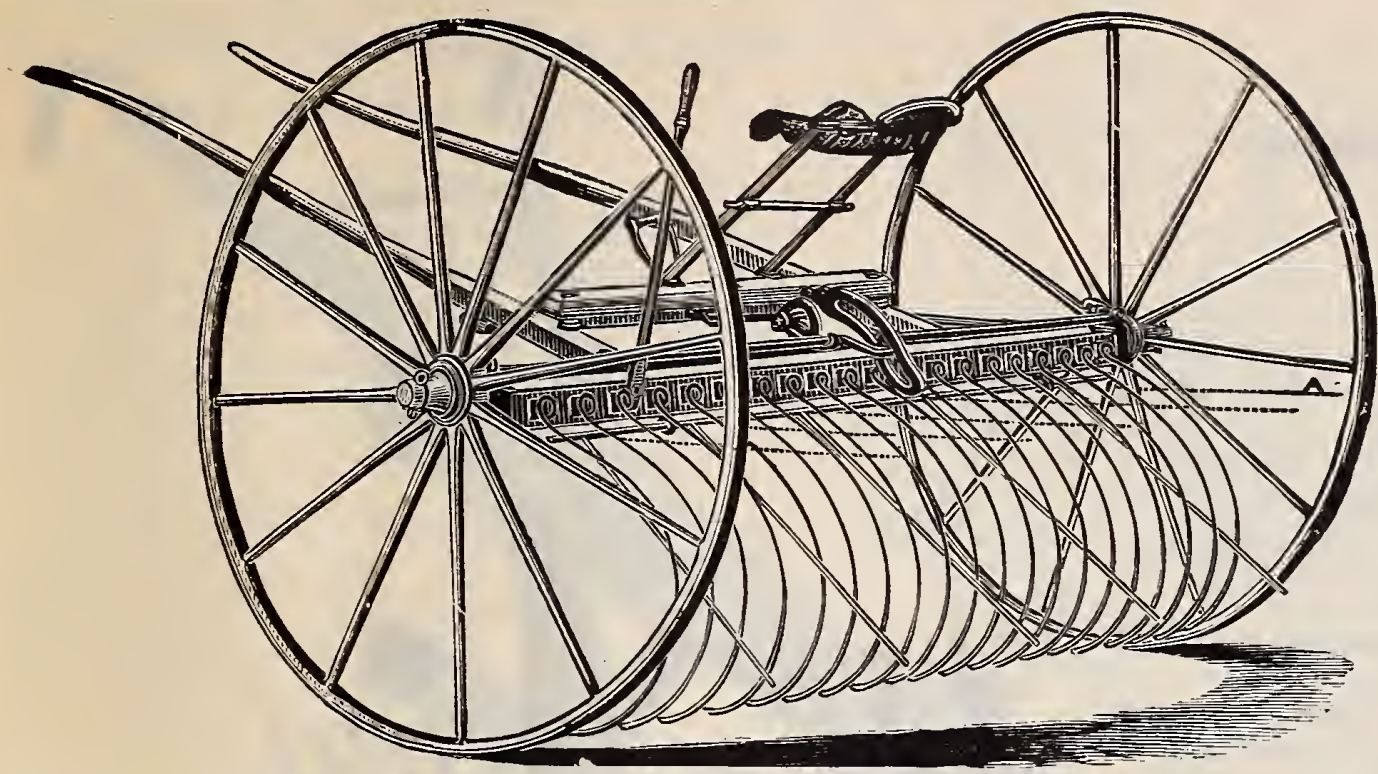

\section{The Champion Rake}

It has a patent tooth to prevent scratching. It has no springs to get out of order. It runs backward as well as forward. It has no Jar on the thills in dumping. Its thills work as freely as those on a carriage. It wi!l not scratch up fine seeding in the harvest field. It will run over trash lying on the ground and leave it there. It can be held down to make very large windrows, or bunch them up. It is very easy to keep up the teeth after going over a windrow. It packs the windrow, leaving it in good shape for rolling up or pitching. It can take the heaviest grass that grows, as soon as cut.

\section{The Yankee Horse Rake}

Some of the leading polnts of superlor excellence found in the Yankee Horse Rake: Simplicity of construction and facility of management. Adaptability to any and all conditions of surface and crops. Operated by the power of the horse and the driver's feet. The rake head is hung so as to balance tha teeth. Teeth running level with the ground at their points. Has more teeth (which are hung nearer together) than any other rakes. All the teeth inserted and removed in less than $t w c$ minutes' time, without disturbing any bolts. Each tooth independent and supplied with a yielding sprin that will permit the tooth to pass safely over any obstruction that the axle will pass over. Don't buy till you see the "Y ankee." Always victorious in every public field trial.

\section{Steel Track Reversible Hay Carrier}

The track is made of Steel T-rails, placed side by side, with space between, large enough to allow hanging hook to pass through. The joints are made alternately, whereby the full strength of one of the rails is retained where the other rail is spliced. The clamp used at the joint has two bolts, which make the track as strong at this point as elsewhere. It is held together entire by a system of clamps. Any ordinary laborer with a monkey-wrench can put it together. The hanging hooks serve also as clamps to hold the track together.

No riveting. It is a complete system, and enables the dealer to supply the farmer with an outfit which can easily be put up. The hanging hooks should never be placed over 4 feet apart, and at point where knocker is placed they should be on every rafter over the load. Always place stop as near under hanging hook as possible. We sell both the Myers and the Ney Carriers.

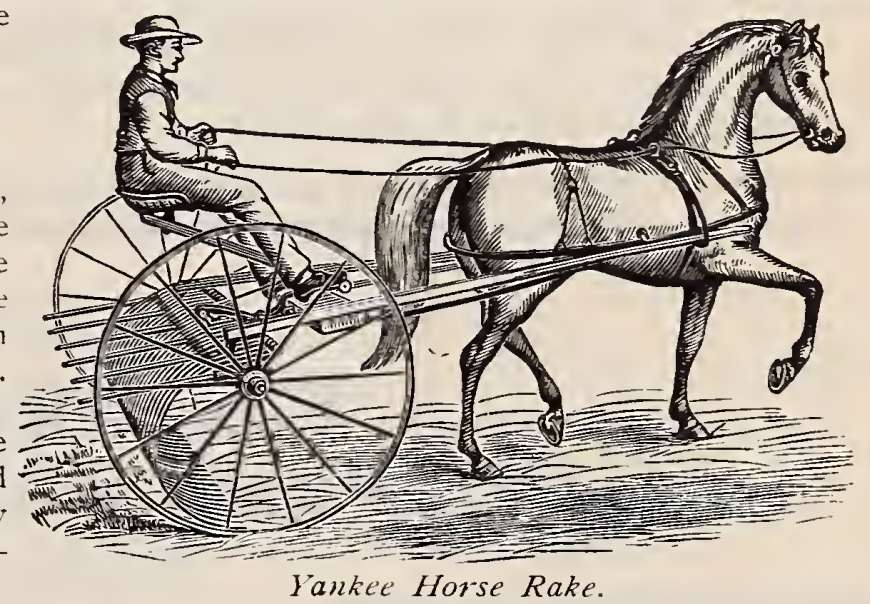

\section{SNATHS}

We shall sell the Now Patent SwIng Socket Snaths manufactured by Dery \& Ball (and sold only by us in Rhode Island). Both crooked and straight bend, in cherry and ash, first introduced by us, have become the favorite with most of our trade. We shall liave a large stock to offer at low prices.

\section{SHOVELS, FORKS AND HOES}

Our stock of Shovels is the largest to be found in Rhode Island. IVe carry a full line of $O$. Ames \& Son's manufacture. We are the sole agents for Rlıode Island for Bachelor \& Son's, and Ely Hoe and Fork Co.'s Steel goods, manufactured by the American Fork and Hoe Co. Our prices will be found as low as any in the market. Lest in New England. We are agents in Rhode Island for th Little Giant, made by the North Wayne Tool Co., also fine Cutlery Steel, Solid Steel, Clipper and Damascus Blade, made by the Dunn Edge Tool Co. These Scythes are guaranteed just as represented. The fact that our sales have doubled in the last few years is good evidence of the qualit:

\section{New Holland Feed Mill}

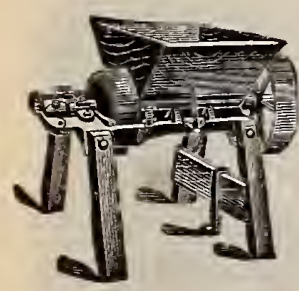

The best Mill at the lowest price. Grinds ear corn, shelled corn, rye, oats, etc. Sizes to run by wind power, weep or tread power or engines of small or large size.

The New Holland Mills are cheap only in price. We believe we have the best Feed Mill on the market to-day and are so confident of it that we ask the privilege of sending it out on a free trial. If you like it, keep it; if you don't, serid it back to us, and there'll be no hard feelings. There's our proposition in a nut-shell. One day's test is worth a whole book of talk.

\section{The Farmer's Handy Wagon. What is it?}

The Farmer's Handy Wagon is a low-down, broad-tire, short-turn, extra strong farm wagon with solid wood wheels - or steel wheels if you will have them - put together to stay together indefinitely, eternally or even longer - built to do work and to handle handily everything ever raised or done on a farm. 


\section{"Success Jr."}

\section{Improved Potato Digger}

The Success Jr. Digger from its first introduction easily took the lead against all competitors, but it was not a success in all varieties of soil, methods of planting and culture.

The principal complaint against it was covering the tubers at the sides of digger, where ridged cultivation wa's practiced.

We ask your attention to the Improved "Success Jr." (all steel, except beam and handles). You will notice at first glance that the new construction of the shovel means effective work, where it was defective before.

\section{NOTICE SOME OF THE IMPROVEMENTS}

I. The rearward curved and elevated wings of the shovel, working in conjunction with the greatly improved screen, completely revolutionizes the working capacity of the digger.

2. The screen is now constructed to give better results, and is held adjustably to the standard by two bolts instead of one as before.

3. The point (which you know wears out sooner than the rest of the shovel) is separated from the main shovel and requires but $3 \mathrm{lbs}$. of steel to renew the point.

The "Success Jr." I mproved has much greater superiority over the Jr. than the Jr. over the original "Success."

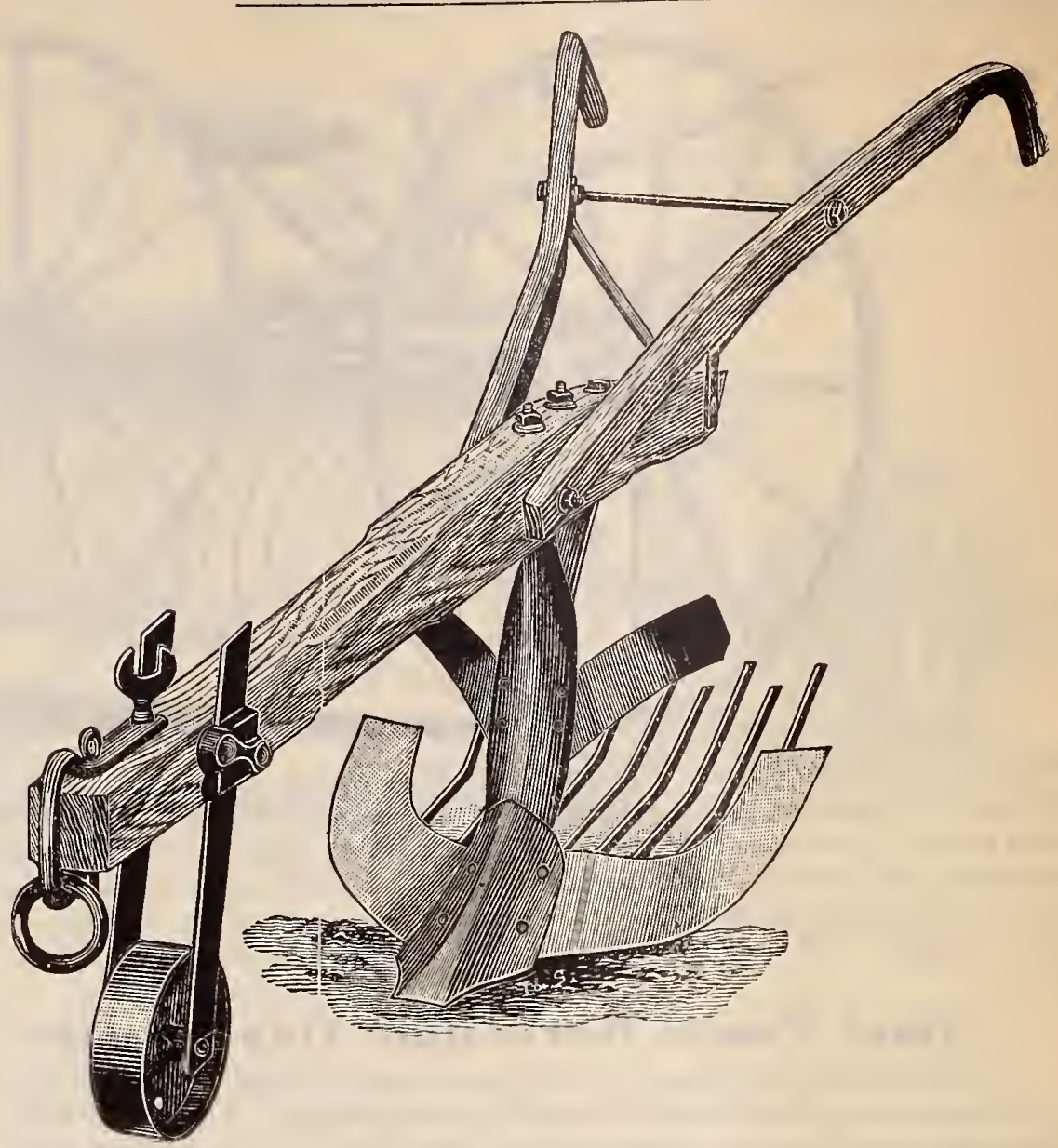

\section{Eureka Fly = Killer}

\section{READ EVERY WORD OF THIS CAREFULLY}

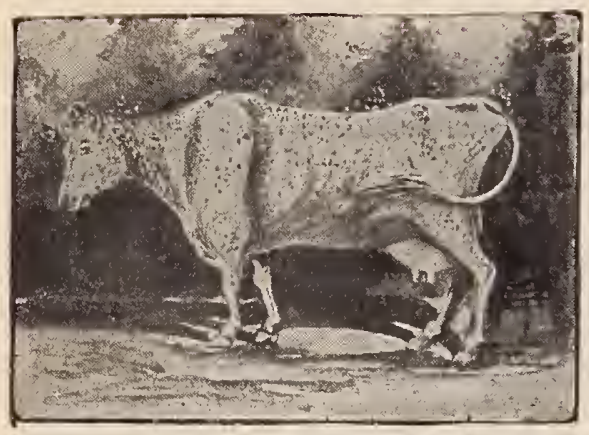

BEFORE USING

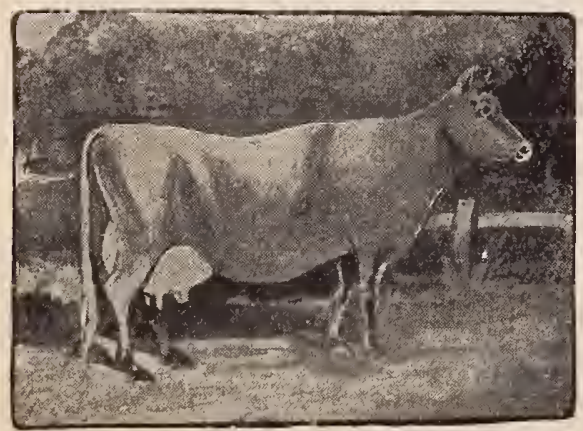

AFTER USINC
To keep flies off cattle and horses spray thoroughly once a day. When the flies are very troublesome twice a day will be found more satisfactory. The Acme Sprayer is admirably adapted for the purpose. It is absolutely necessary that the leather on the sprayer plunger be kept zell oiled and the sprayer in condition to throw a liberal spray.

\section{For Lice on Cattle}

Spray thoroughly and card the animal to work the Killer into the hair.

\section{For Hog Lice}

A good, liberal application is all that is required.

\section{For Killing Lice and Mites in Poultry Houses}

There is no preparation on the market that can excel Eureka for this. Spray the roosts, crevices and all parts of the house where mites lodge. First make a light application which will cause the vermin to come to the surface, following in about ten minutes with a more liberal spraying, and you will be surprised at the splendid results. After ridding the house of vermin spray every week or two and you will have no further trouble with the pests.

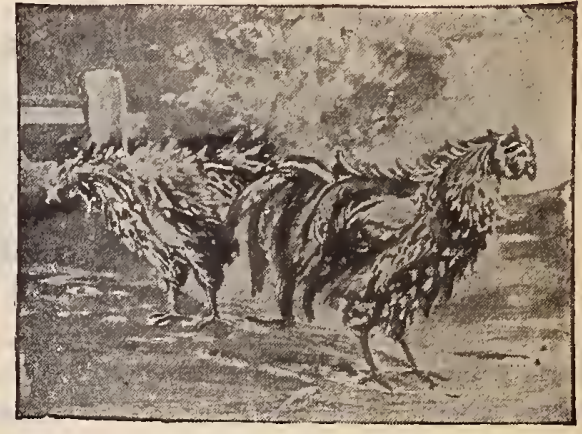

FEEL BAD-LOOK BAD

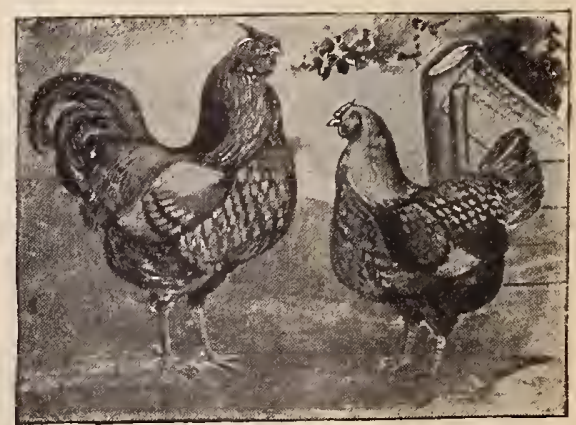

FLY-KILLER DID IT 


\section{St. Alban's Stump Puller and Stone Lifter}

We have no hesitation in saying that this machine is the simplest and most efficient derice ever invented for pulling stumps, lifting stones, and handling all kinds of heary bodies, and we warrant it to be superior to others now in use, for durability and despatch, as well as the ease with which it can be worked and applied to different uses.

This principle of acquiring power is a compound leverage, rery similar to the pinch bar used to roll a car wheel, for starting a loaded car by hand-power, etc.

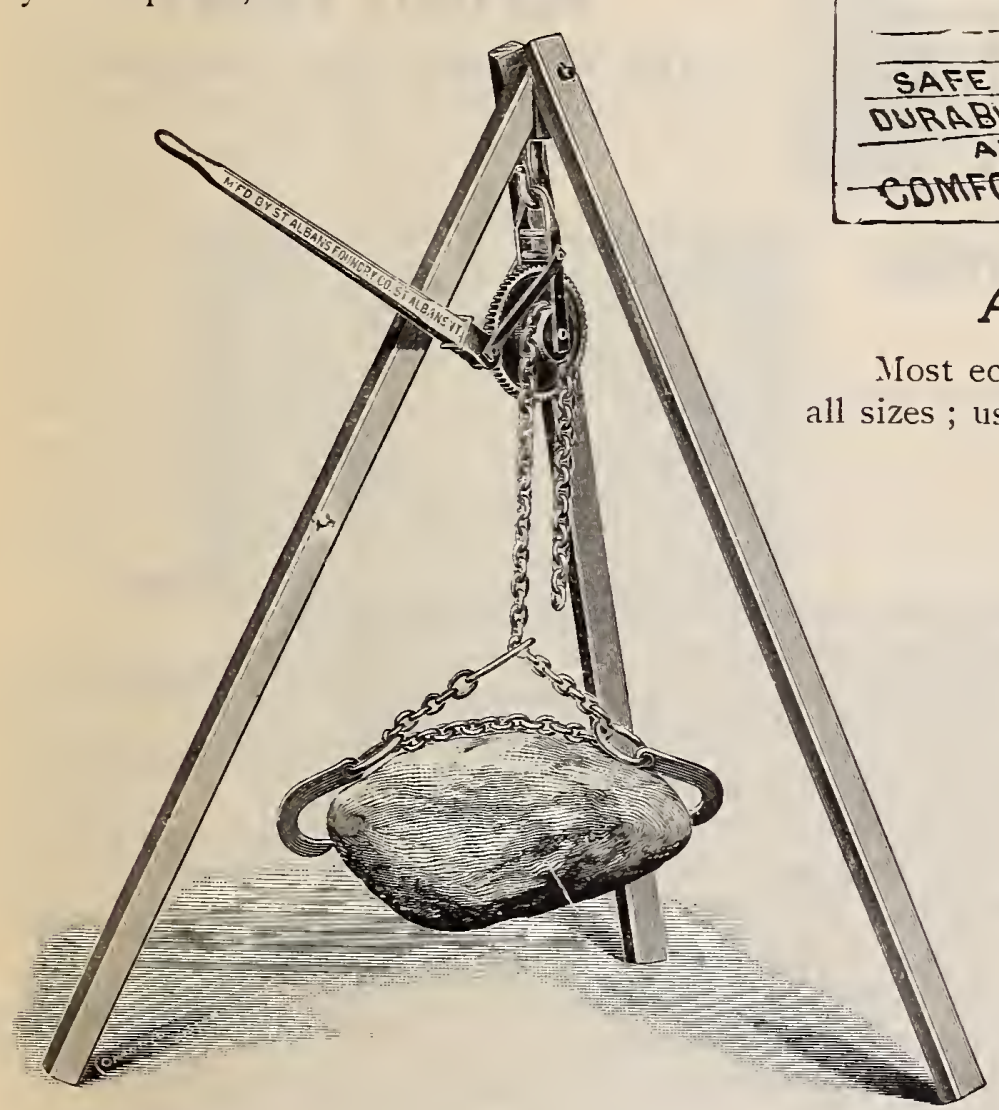

St. Alban's Stump Puller and Stone Lifter.

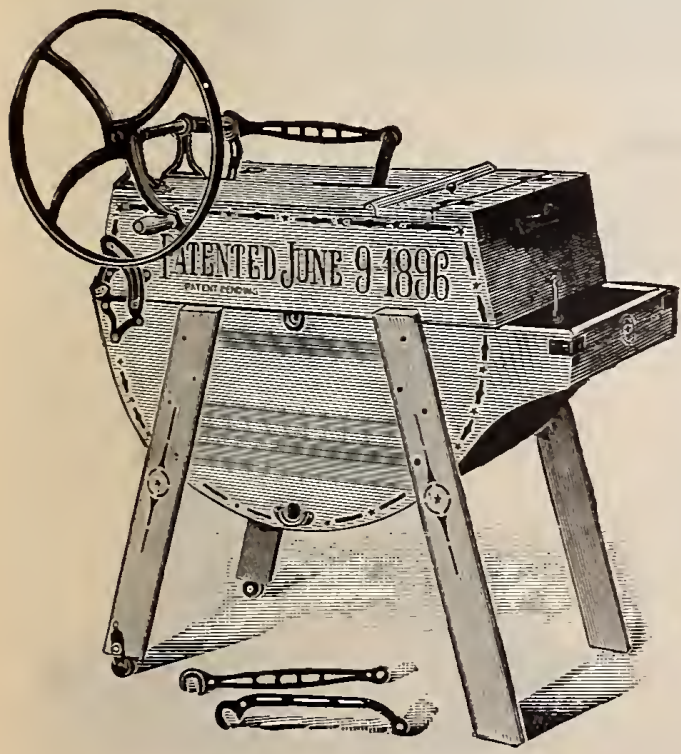

The Glory Washer

This machine has external gears with corrugated cylinders. All four sides of the vibrating cylinders corrugated.

Every machine guaranteed. We have several other styles to select from. A Washing Machine is a necessity in every family.

The Glory Washer.
This swing is made entirely of hard wood. The standards are of maple or birch, and the rest of the swing of oak or white two parts and fastened together in such a way that it makes hem much stronger and less liable to twist or break.

The finish of the swing is the result of painstaking efforts to produce the best-looking swing that can be made at a reasonable price, and finished as they are, in golden oak, with red standards,

The swing can be set up or taken down without loosening a bolt or screw, which is an advantage to all who use a swing. Heighth width of sezt No. 6 feet 16 in. No. 2 . 8 feet 18 in. No. 3 . Io feet $28 \mathrm{in.}$

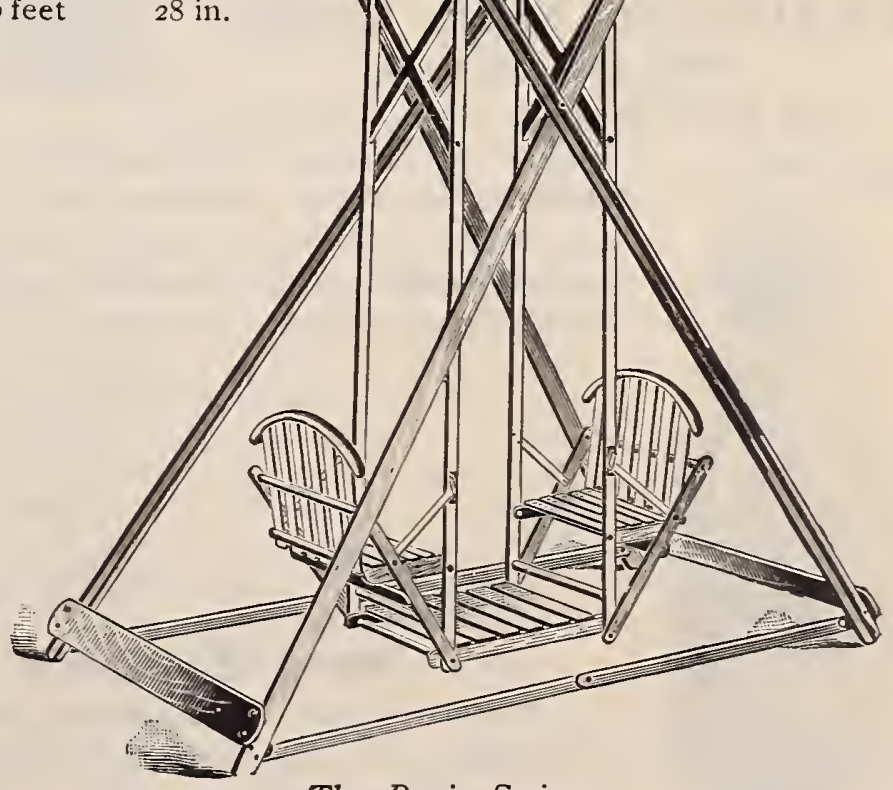

The Paris Swing 


\section{AGENCY FOR THE}

\section{AMERICAN S STEEL WOVEN WIRE FENCE}

\section{Made of Large, Strong Wires, Heavily Galvanized.}

Amply provides for expansion and contraction. Only Best Bessemar steel wires used. Always of uniform quality. Never goes wrong no matter how great a strain is put upon it. Does not mutilate, but does efficiently turn cattle, horses, hogs and pigs.

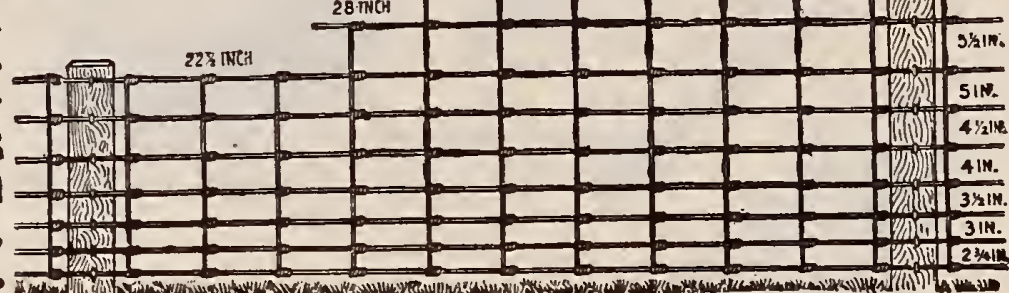

\section{EVERY ROD OF AMERICAN FENCE GUARANTEED}

\section{BY THE MANUFACTURERS.}

Call and $\mathrm{S} \theta \Theta$ it. Can show you how it will save you money.

\section{Ellwood Standard Fence}

This fence is made in six heights. The lower heights all have smaller meshes, while the higher patterns have a more open mesh at the top. Small animals seek to break through the lower part of the fence only; and the upper part of the fence with the larger mesh is amply strong for turning the most unruly of the larger animals. Every rod of Ellwood fence is guaranteed.

\section{Ellwood Poultry and Rabbit Fence}

THIS IS A FENCE-NOT A NETTING. A strong and all-important distinction. Twisted coiled cables and single lateral wires, No. If; cross wires, No. I6. All heights have twisted cable at top. Mesh up to and including 42-inch height, 2 -inch; above 42inch height, mesh 4-inch. No need of smaller mesh above 42 -inch height, as poultry or rabbits never go through the upper part of fences, but always attack the bottom. While this style is especially designed as a poultry and rabbit fence, it is sufficiently strong to stop all larger animals. Costs practically the same as the flims! nettings, while in the matter of service and durability it is worth ten times as much.

\section{Ellwood Lawn Fence}

The Ellwood Lawn Fence is the outcome to meet the many demands made for a fence at once strong, beautiful and inexpensive, for fencing lawns and yards in towns and villages, for parks, cemeteries and private or public grounds, where beauty as well as utility is required.

The Ellwood Lawn Fence is the strongest possible woren-wire combination, having been tested uncler most exacting conditions.

\section{Champion Milk Cooler SPECIAL CLAIMS}

It is a perfect aerator, removing all flarors

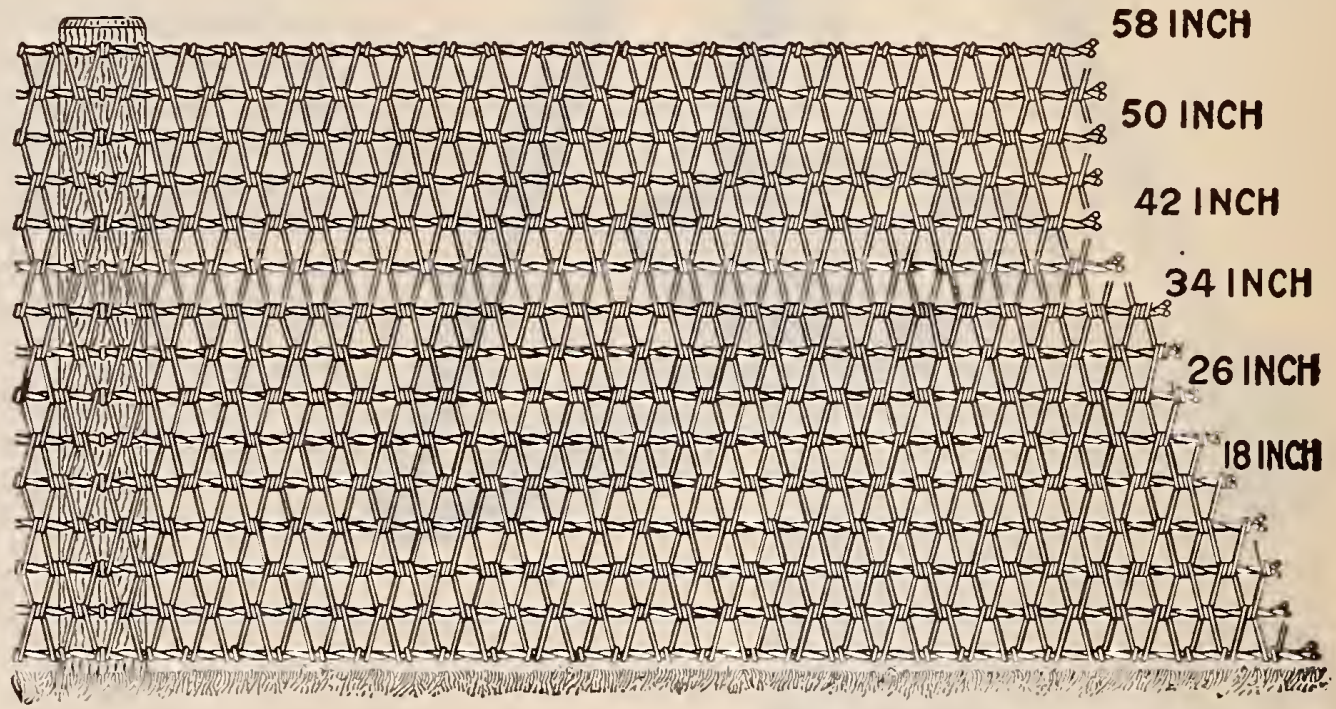

arising from excessive cabbage, turnip or silo rations. It is a complete deodorizer, remoring the animal heat or cony taste and all odors arising from the absorption by the milk of stable or other unpleasant gases. It is a thorough cooler, reducing the temperature of the milk in one minute nearly to the temperature of the cooling medium.

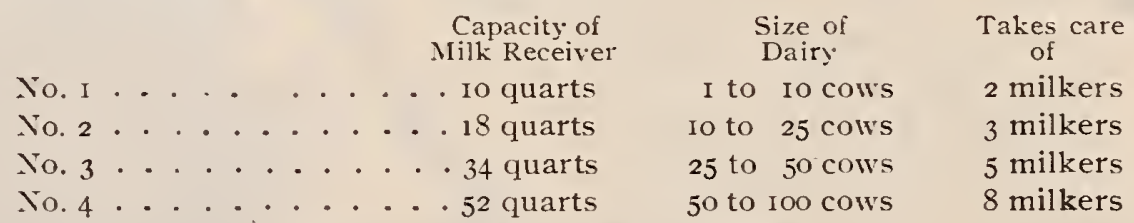
Extra sizes on special orders.

New Empire Milk Bottle STRONGEST, CLEAREST AND IN GREAT DEMAND

For pulp or tin caps. Rounded bottom. Quart, pint and one-half pint. Best glass. Most attractive shape; easily cleaned. Prices on application.

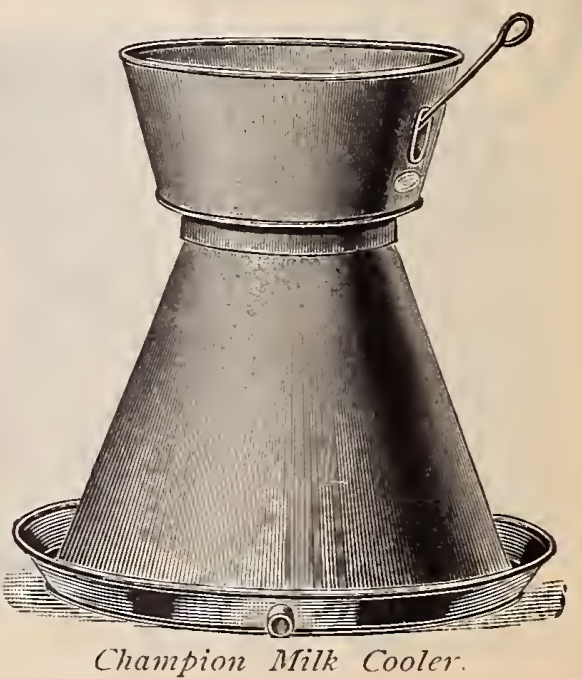




\section{Poultry Supplies, Etc.}

Pratt's Food for Morses and Cattle. What is it? A purely vegetable preparation, containing no mineral or other poison. It is not a medicine nor a condition powder. What it will do: Regulate the bowels, blood and digestive organs, and therefore for horses it will prevent indigestion and loss of appetite. Cows will give richer milk and more of it. Young pigs grow up free from disease, and fatten quickly; their meat will be juicy and tender. Pratt's Food for Horses and Cattle is put up in I2-, 25-, 50and 100-pound sacks.

Pratt's Poultry Food. It is an entirely different food from the Horse and Cattle Food. It is put up in 25-cent and 6o-cent packages, and I2- and 25-pound sacks; is guaranteed to cure and prevent all diseases of the flock, and makes hens lay regularly all seasons of the year.

Rust's Havens' Climax Condition Powders. Contain nothing harmful as a medicine, and are a general preventive for diseases of Fowls, Horses, Cattle, etc. A re very popular.

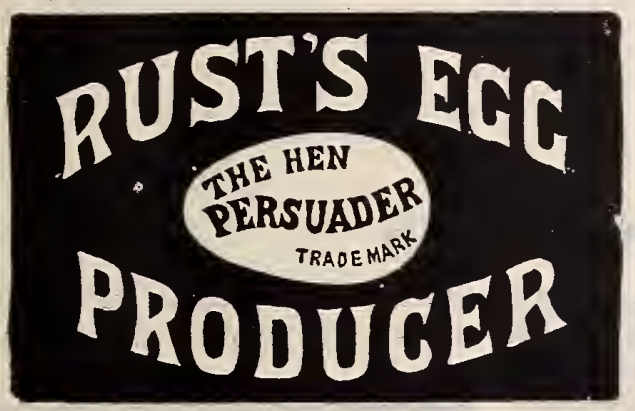

Rust's Egg Producer. Think of it! You can feed Rust's Egg Producer every day for two or three weeks at a cost of one cent for each hen. and get surprising results.

Cut Clover. This supplies a long-felt want in the line of a natural vegetable food; is being used largely this season.

Clover Meal. Selẹcted clover hay ground very fine for mixing with soft feed. Excellent for laying hens.

Dr. Mess' Poultry Pan-a-ce-a is the scientific compound for poultry. Poultry Pan-a-ce-a cures diseases and makes hens lay. It has special merit peculiar to itself; take no "Poultry Food" or "Poultry Powder" as a substitute. Poultry Pan-a-ce-a is not made from a formula, but from an actual and practical knowledge of every condition and disease that fowls fall heir to.

Dr. Mess' Stock Food. The scientific compound for Horses, Cattle, Hogs and Sheep. This preparation will increase flesh and yields of milk to an extent absolutely unattainable without it. It is a guaranteed cure for hide-bound, blood disorders, indigestion and all ailments due to an impoverished condition of the system. It should not be considered either as a medicine or a substitute for hay, grain or other feed. It is nutritious and curative. It corrects digestion, tones up the system, improves the circulation and supplies the laxative so necessary in keeping the bovels in a healthy condition.

Blatchford's Calf Meal. The perfect milk substitute for raising calves. One hundred pounds of it makes 100 gallons of rich, nutritious gruel. Thousands of farmers say Blatchford's Calf . Leal builds up calves fast and well at much less expense and trouble than any othermilk substitute. Calves can be räised upon it alone without milk at all after they are a few days old, and this can be done with no other milk substitute.
Used with separator milk or skim-milk it replaces the butter-fats in same, and makes them as nutritious as new milk. Even when whole milk is used, the feeding of Blatchford's Calf Meal with the milk builds up much finer, bigger and sturdier calves in about half the usual time. Blatchford's Calf Meal is also a great preventive of "scouring," and worth its cost for this purpose alone. It contains pure dried milk. It is nnt oil-meal with all the oil out of it, or dried blood, or the by-product of some other manufactured article. Dried blood, for instance, is scarcely adapted for herbivorous animals.

Mann's Crystal and Rocky Mill Grit. Far superior to oyster shells. Poultry raisers have long desired to secure a sharp, clean grit of regular size and superior quality. Nica Grit is prepared to meet this demand, and has been thoroughly tested.

Sheridan's Condition Powders. Of world-wide reputation. These powders are strictly a medicine, not a food.

Our stock of Beef Scraps, Ground Oyster Shells, Ground Bone and Mixed Feed is always fresh. Wheat, Wheat Screenings, Buckwheat, Barley and Oats, etc., for feeding, always on hand.

Poultry Netting. We have a large stock of the best" makes, Clinton and Gilbert and Bennett's, different widths from I to 6 feet, at lowest market prices.

H-O Poultry Food. We claim for the H-O Company's Poultry Food: First, that it is all grain. Second, that it will furnish bone and promote growth in young fowls. Third, that it will insure the highest results in the production of eggs. Fourth, that it will shorten the moulting period; that it is entirely free from all medication and unnatural stimulants, and keeps the fowl in prime condition by the natural means of a properly balanced food.

M-O Scratch. Made from finest grains and granulated almost fine enough for smallest chickelis.

H-O Morse Feed keeps horses in good condition, prevents colic, scouring and indigestion.

Animal Meal. This preparation is made from fresh beef and bones specially prepared for an egg-producing food. Fowls fed on this occasionally will be healthy and strong.

Puritan Laying Stock Food will furnish your fowl at all times of the year with a perfectly balanced grain stock ration, and also with the nitrogenous matter so essential to the quick and the inexpensive production of the egg. It is a complete food in itself, and contains all the muscle-building and egg-producing: elements which are absolutely essential to the laying hen.

Puritan Chick Food. This food is used on the Puritan Farms, and what it has already done there is sufficient proof of its efficacy ; still, since its advent upon the market it has been hailed only as an article can be that is in actual demand, and that gives proof at once to all that it fills all the requirements that are claimed for it

Chicken Food, Greene's. It is made from selected grains of the first quality, and is especially prepared as a ration on which chickens may be raised to maturity with the best possible results. It is a highly concentrated food, as each grain is chemically and mechanically treated. The indigestible elements are eliminated, while the protein is maintained very high, and the carbohydrates are reduced to the proper proportions and, with the addition of the best-known condimental seeds which act directly on the reproductive organs, we have a perfectly balanced food, which devetops quickly the body of the chick and stimulates the reproductive organs from the first, assuring very early layers

Poultrymen buying in laüge quantities could save móney by looking us over Get our Prices. $x \rightarrow$ We are the largest dealers in Poultry supplies in Rhode Island. 


\section{Incubators, Brooders, Etc.}

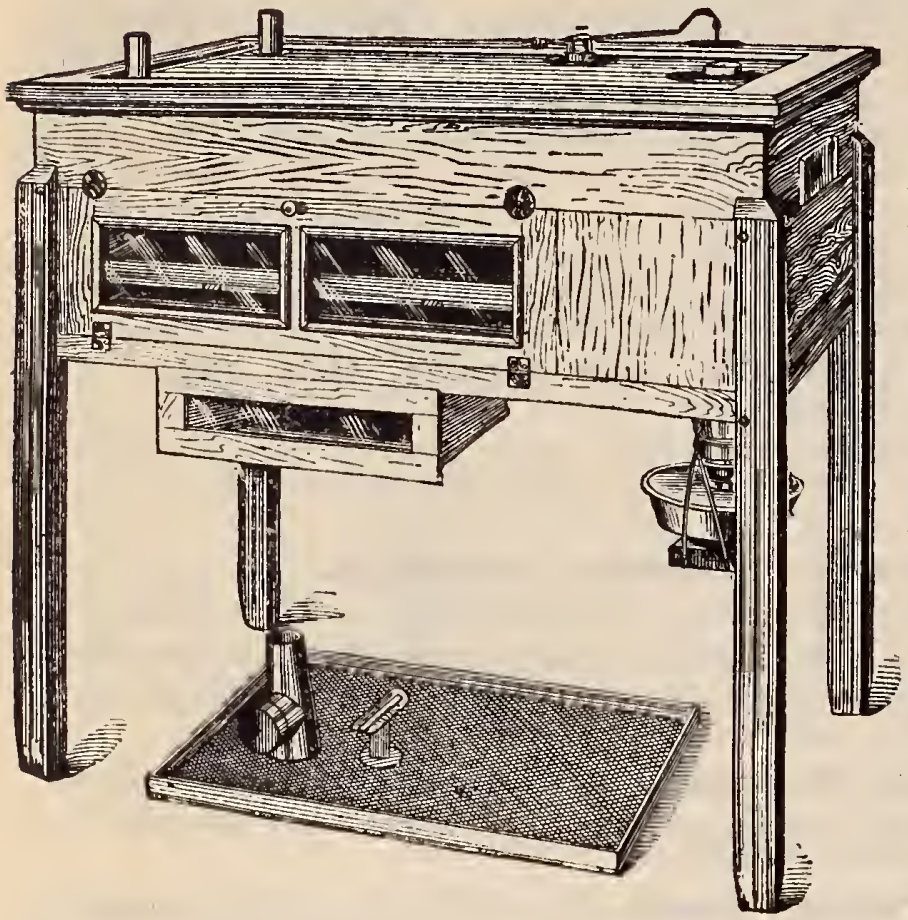

\section{THE STAR INCUBATORS}

We have handled these incubators for the past four years and have found them to do perfect work. The Star Incubators liave a perfect system of ventilation; the galvanized radiator is placed directly over the eggs. This radiator contains three galvanized pipes, which distribute the heat evenly before entering the egg chamber. The lamp is under the nuachine, making a direct connection to leat radiator.

No moisture is required on account of perfect system of ventilation. The Star Catalogue will be mailed to any person. This will give more thorough explanation of the machine than this space will allow. They are manufactured in four sizes, all of which are double case machines.

Star Incubators are furnished complete, ready for use; this includes tray or trays (where the machine requires two or three), lamp all complete, thermometer and thermometer stand, instruction book, egg tester, lamp stand; in fact, everything necessary for its operation.

See the new Regulator.

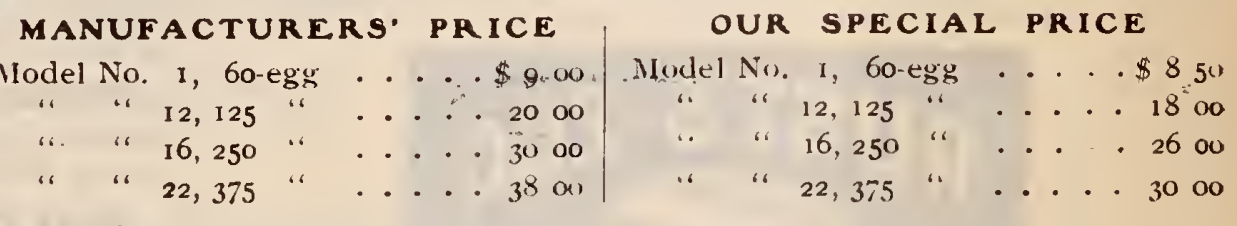

\section{OLD HOMESTEAD BROODERS}

The Old Homestead Brooder is entirely free from all pipes, lamps or other obstruction, every inch of the inside of Brooder being for the use of the chicks alone; each one being visible at a glance through the windows or cover-doors. We know of no other make having to such an extent this advantage ; but do know of many having low, flat hovers full of hotair or water-pipes, lamps, stoves or other fixtures, always in the way of chicks and operators.

Both the hover and feed-room are lighted with large windows. Chicks do not like a dark brooder. The chicks can be seen through the hover windows, making it unnecessary to open the cover doors except to clean out.

Brooders are complete, with lamps, thermometers, and everything necessary for in mediate use. Bee the now Aluminum Lamp.

\section{PRICES}

Indoor D Brooders, too chicks. . . . . . . . . . . . \$1 I oo

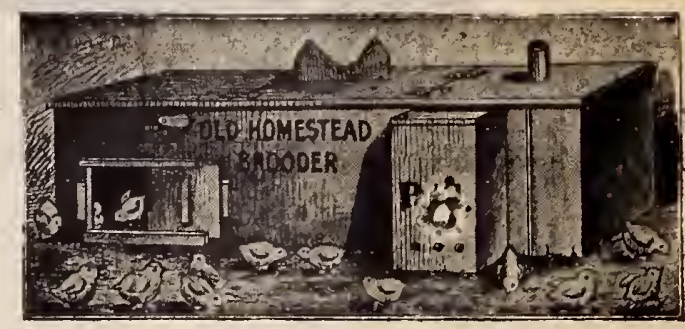

\section{STAR BROODERS}

Star Special Bruoder. . . . . . . . . . . . . . \$550

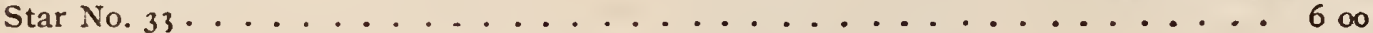

Star No. $22 \ldots \ldots \ldots \ldots \ldots$

\section{Thompson's Banner Root Cutter No. 7, for Poultrymen}

Cuts all roots and vegetables in the best possible condition for feeding all kinds of poultry, young lambs, etc. Can be used to good advantage by horsenien feeding carrots, and by small dairymen; turns easily, cuts fast, and is the most efficient little Root Cutter ever made. Choking an impossibility. Feed left in long, small, thin strips. We have no hesitancy whatever in recommending this Cutter to poultrymen, because we know it will do the work just as they want the roots prepared for feeding.

\section{Mann's Green Bone Cutter}

You don't know what a Bone Cutter really is until you see Mann 1905 model ; different from all others, new design, open hopper, enlarged table, new device to control feed.

The Mann's is the machine which cuts hard bones without any more exertion than is required for soft bone. The machine which you can regulate to suit the strength of the operator. The machine which does not clog or stall; the machine which not only cuts bone, but any bone and all bone, meat and gristle. Try it for yourself and see. The new catalogue explains all.

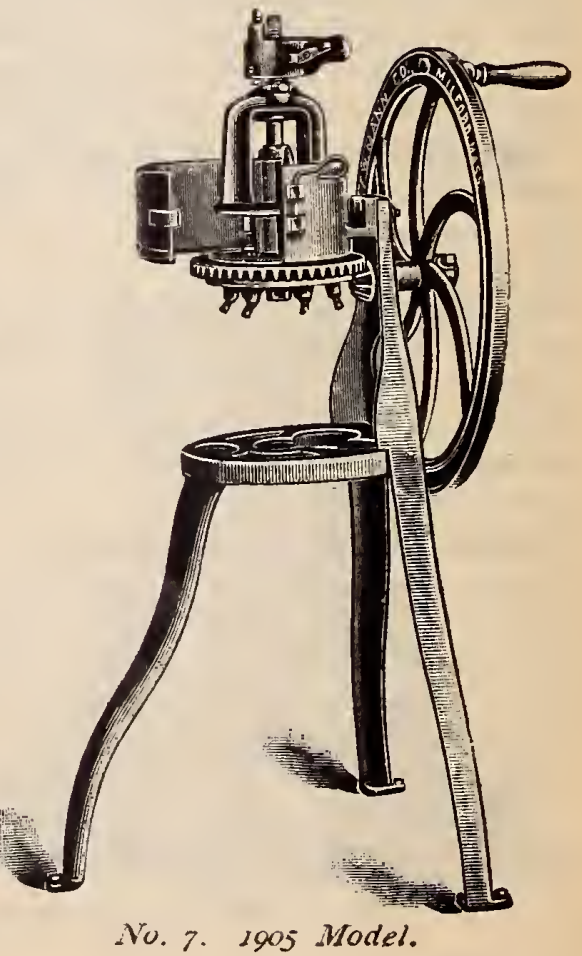




\title{
Glacier Refrigerator
}

We are the Rhode Island agents for the GLACIER and DEFENDER Refrigerators, and our experience in selling them the last four seasons enables us to say, without hesitation, that they are the best Refrigerators on the market today, price and construction considered, as hundreds can say who have bought them. If you want a first-class Refrigerator in every respect, we have it in the Glacier, all sizes and styles, and invite your inspection.

THE GLACIER IS GUARANTEED TO BE THE BEST REFRIGERATOR IN THE WORLD FOR THE PRICE.

It is made on the cold, dry air system, and is the result of the highest order of scientific skill and ingenuity. It prevents the ice from melting rapidly, soon saving its cost in ice bills. It is conveniently arranged, and has seven walls. Made of solid ash, and is beautifully finished.

"The Marble Heart" you read about is a coal of fire compared with the intericr of the Glacicr Refrigeritor. Sind or call for descriptive Catalogue.

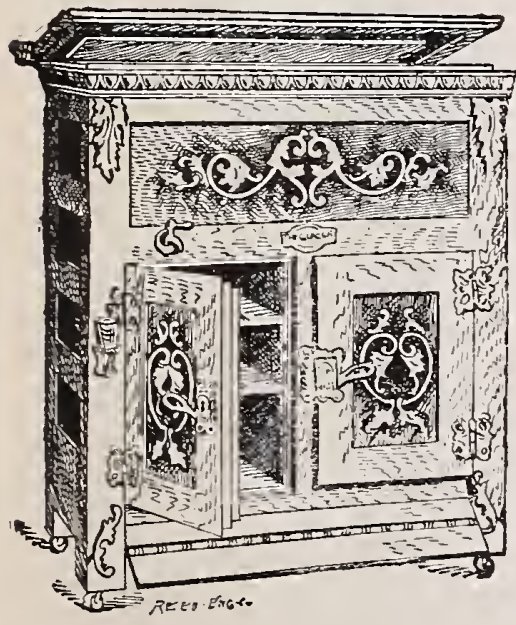

\section{The DEFENDER Hard-Wood REFRIBERATOR}

In ofiering the Defender to the public, we wish to state that it is made to compete with any soft-wood Refrigerator as a better article for the same money. 'It is insulated with charcoal sheathing, which some manufacturers consider the best material obtainable. The locks are all solid bronze, and the shelves are of galvanized iron. The finish is light antique.

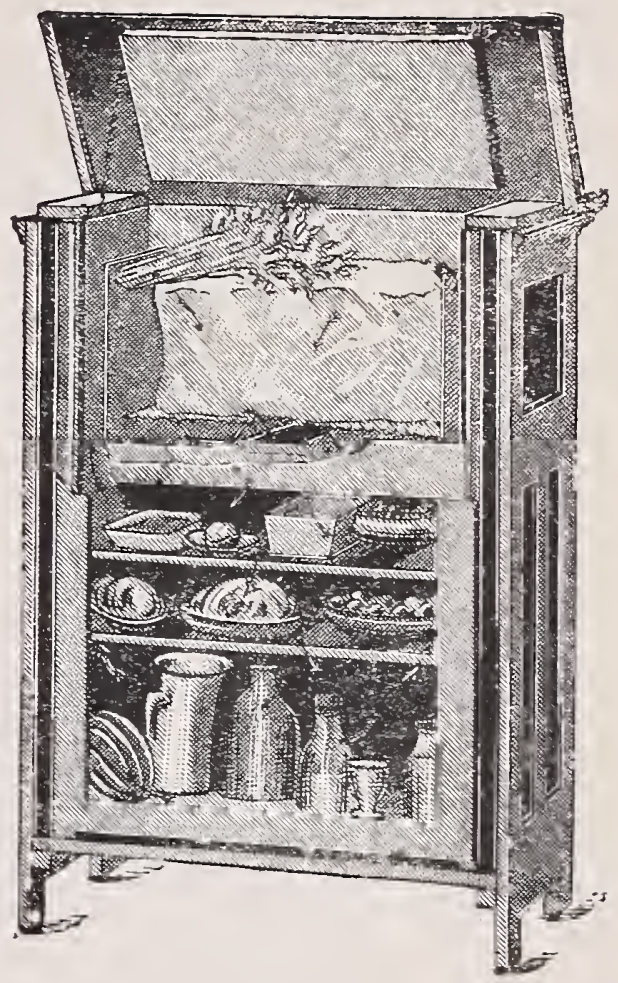

\section{Genuine Porcelain Lined Refrigerators}

We wish to call your special attention to our real Porcelain Lined Refrigerators. We do not mean by this that it is white enamel paint on galvanized iron, but real porcelain on heary sheet steel. The porcelain is fused onto the steel at a temperature of $2500^{\circ}$ Fahrenheit, and is proot against corrosion by grease or acid. It is much better than crockery tiles, which are sure to craze, or opal glass, which is easily broken. Another objection to tile lining is the fact that it is made up with many joints which will soon be filled with impurities.

Not only is the entire provision chamber lined with real porcelain, but the slielves are also made of the same material.

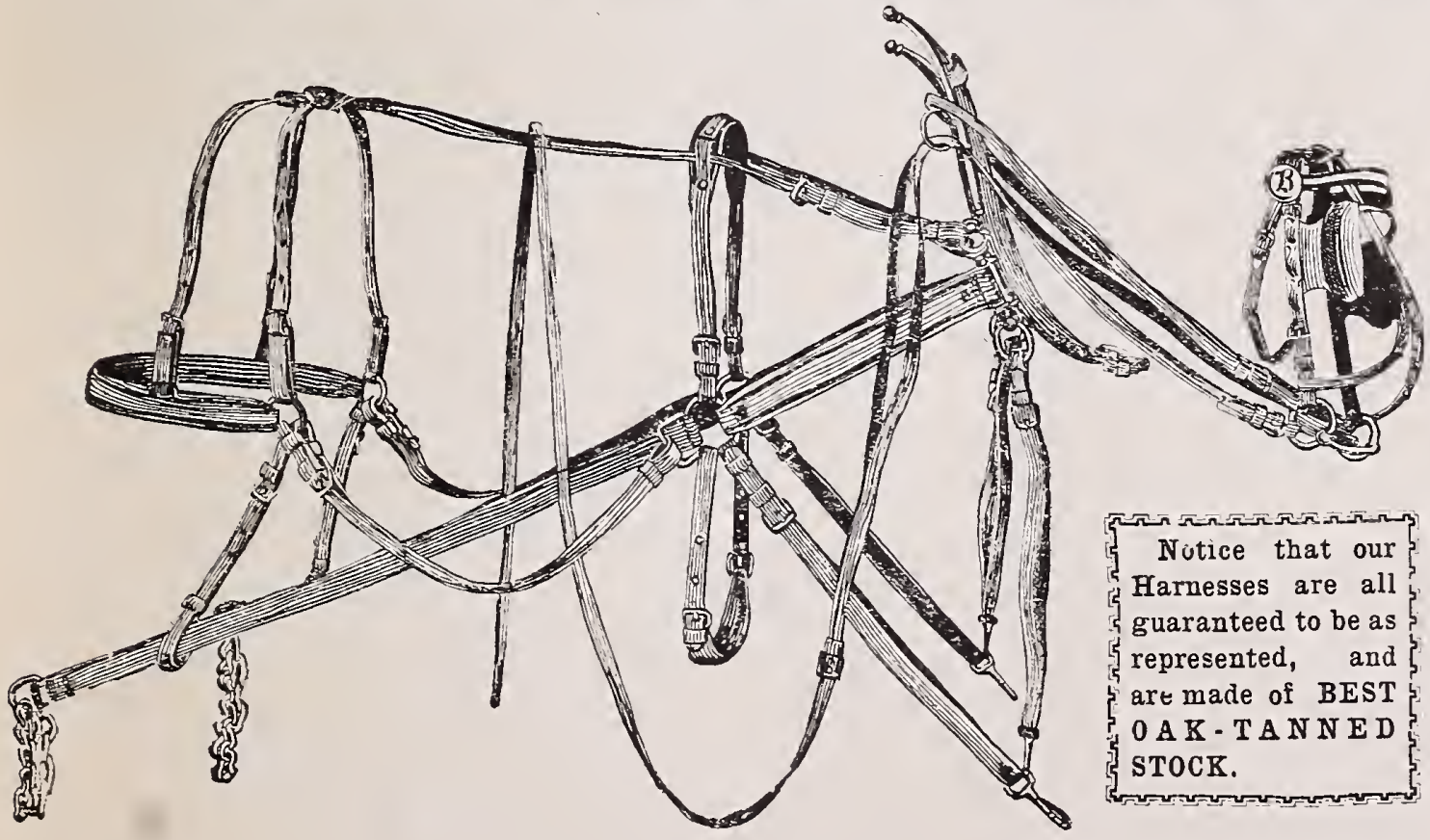

\section{HARNESSES}

If you should buy a Farm Waron, Horse Cart, Mianure Spreader, or any like article of us, what would be more natural than that you should ask us, "Do you sell Harnesses?" We would answer, that for this very reason we carry in stock, at all times, a line of Marnesses adapted for farm and general work, also express and buggy Mar. nesses in many styles. All of these are guaranteed to be as represented, and are made of best oaktanned stock.

In this department will also be found a full line of Collars, Malters, Hitch Ropes, Feed Bags, etc.

\section{The $W$. E. Barrett Company,}

\author{
PROVIDENCE, R. I.
}




\section{Chinese Giant Pepper} Photograph of Specimens grown by Mr.H.N.Reed, Knightsville, R.I. Only one-half the actual size.

THIS IS THE STOCK WE SHALL SELL THE SEASON OF 1905. IT CAN BE RELIED ON AS PURE AND TRUE TO NAME.
ONE PEPPER WEIGHED $11 \mathrm{lb} .2 \mathrm{oz}$. EIGHTEEN WEIGHED

$17 \frac{1}{2}$ lbs. AND MORE THAN FILLED A HALF BUSHEL BOX.

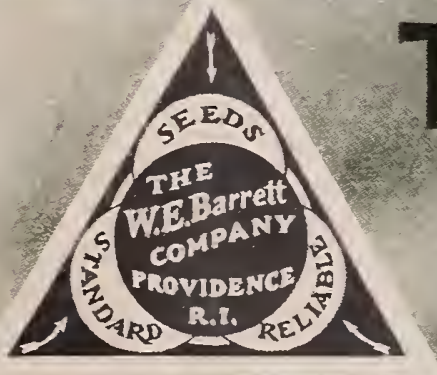
The
W. E.BARRETT

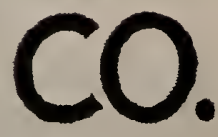
65 to 87 CANAL ST. PROVIDENCE, R.I. 